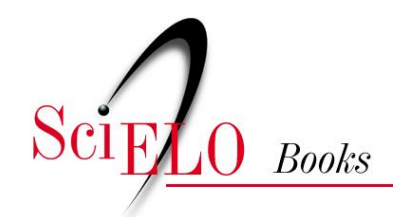

\title{
O Demoníaco na Literatura
}

\author{
Antonio Carlos de Melo Magalhães \\ Eli Brandão \\ Salma Ferraz \\ Raphael Novaresi Leopoldo \\ (orgs.)
}

MAGALHÃES, ACM., et al., orgs. O demoníaco na literatura [online]. Campina Grande: EDUEPB, 2012. 290 p. ISBN 978-85-7879-188-9. Available from SciELO Books <http://books.scielo.org>.

\section{(c)}

All the contents of this work, except where otherwise noted, is licensed under a Creative Commons Attribution-Non Commercial-ShareAlike 3.0 Unported.

Todo o conteúdo deste trabalho, exceto quando houver ressalva, é publicado sob a licença Creative Commons Atribuição Uso Não Comercial - Partilha nos Mesmos Termos 3.0 Não adaptada.

Todo el contenido de esta obra, excepto donde se indique lo contrario, está bajo licencia de la licencia Creative Commons Reconocimento-NoComercial-CompartirIgual 3.0 Unported. 


\section{uepb \\ Universidade Estadual da Paraíba \\ Profa. Marlene Alves Sousa Luna | Reitora \\ Prof. Aldo Bezerra Maciel | Vice-Reitor \\ Seduepb \\ Editora da Universidade Estadual da Paraíba \\ Cidoval Morais de Sousa | Diretor}

\section{Conselho Editorial}

\section{Presidente}

Cidoval Morais de Sousa

\section{Conselho Científico}

Alberto Soares Melo

Hermes Magalhães Tavares

José Esteban Castro

José Etham de Lucena Barbosa

José Tavares de Sousa

Marcionila Fernandes

Olival Freire Jr

Roberto Mauro Cortez Motta

\section{Editores Assistentes}

Arão de Azevedo Souza

Antonio Roberto Faustino da Costa

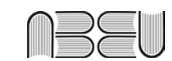

Editora filiada a ABEU

EDITORA DA UNIVERSIDADE ESTADUAL DA PARAÍBA

Rua Baraúnas, 351 - Bairro Universitário - Campina Grande-PB - CEP 58429-500

Fone/Fax: (83) 3315-3381 - http://eduepb.uepb.edu.br - email: eduepb@uepb.edu.br 
Antonio Carlos de Melo Magalhães

Eli Brandão

Salma Ferraz

Raphael Novaresi Leopoldo

(Organizadores)

\section{O Demoníaco na Literatura}


Copyright (C) EDUEPB

A reprodução não-autorizada desta publicação, por qualquer meio, seja total ou parcial, constitui violação da Lei $n^{\circ} 9.610 / 98$.

A EDUEPB segue o acordo ortográfico da Língua Portuguesa de 1990, em vigor no Brasil, desde 2009.

\section{Editora da Universidade Estadual da Paraíba}

Cidoval Morais de Sousa | Diretor

Arão de Azevêdo Souza | Editor Assistente de projetos visuais

Antonio Roberto F. da Costa | Editor Assistente de Conteúdo

\section{Editoração Eletrônica}

Jefferson Ricardo Lima Araujo Nunes

Leonardo Ramos Araujo

Design da Capa

Erick Ferreira Cabral

Ilustração da Capa

Erick Ferreira Cabral

Coordenação de Distribuição e Livraria

Júlio Cézar Gonçalves Porto

Comercialização

Álisson Albuquerque Egito

Divulgação

Zoraide Barbosa de Oliveira Pereira

Depósito legal na Biblioteca Nacional, conforme decreto $n^{\circ} 1.825$, de 20 de dezembro de 1907.

FICHA CATALOGRÁFICA ELABORADA PELA BIBLIOTECA CENTRAL - UEPB

133.42

D384 O demoníaco na literatura./ Antonio Carlos de Melo Magalhães; Eli Brandão; Salma Ferraz; Raphael Novaresi Leopoldo (Orgs).

- Campina Grande: EDUEPB, 2012

292p.: il.

ISBN: 978 - 85 - $7879-137$ - 7

1. Literatura. 2. Demônio 3. Religião. I. MAGALHÃES, Antonio Carlos de Melo. II. BRANDÃO, Eli. III. FERRAZ, Salma. IV. LEOPOLDO, Raphael Novaresi. V. Título

21. ed. CDD 
"Que coisas que nós não sabemos haverá entre o

Diabo e Deus"

José Saramago,

O Evangelho Segundo Jesus Cristo 



\section{Sumário}

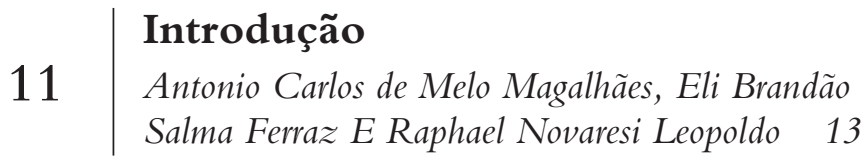

As bem-aventuranças nas versões de Borges,

15 de Machado de Assis, da Bíblia satânica de Anton Lavey e na versão ao mestre com carinho Salma Ferraz

Primórdios do mito Faústico: o Faustbuch

47 e o Fausto de Christopher Marlowe 47 Antonio Augusto Nery

63

O diabo enquanto personagem literário em O bom diabo de Monteiro Lobato e Belzebu.com, de Luis Fernando Veríssimo Filipe Marchioro Pfützenreuter

77 | $\begin{aligned} & \text { O Diabo: O Malfeitor Cósmico } \\ & \text { Raphael Novaresi Leopoldo (UFSC) }\end{aligned}$

91 A figura do Diabo nos Sueños de Quevedo Andréa Cesco (UFSC)

A virulência da flor peçonhenta do desespero: o profano e o demoníaco em Lavoura Arcaica de Raduan Nassar 103 Raphael Bessa Ferreira (UEPA) 
113 |l|l| $\begin{aligned} & \text { Baudelaire e Belzebu113 } \\ & \text { Larissa Drigo Agostinho }\end{aligned}$

125 \begin{tabular}{l|l} 
O Satã de John Milton \\
Fabiano Seixas Fernandes
\end{tabular}

$139 \begin{aligned} & \text { Uma comparação entre os Satãs } \\ & \text { do Paradise Lost e Paradise Regained } \\ & \text { Paloma Catarina Zart }\end{aligned}$

\section{Algumas considerações sobre o}

149 Diabo na Divina Comédia

Daniel Lula Costa

Solange Ramos de Andrade

\section{Demoniologia de Eça de Queiroz}

161 no conto O Senhor Diabo

Davi da Silva Oliveira

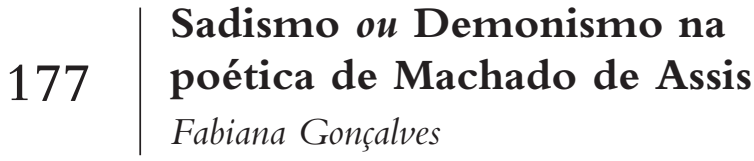

$189 \begin{aligned} & \text { cultura africana em Do Amor e Outros } \\ & \text { Demônios, de Gabriel García Márquez }\end{aligned}$

Fernanda Medeiros de Figueirêdo

\section{A demonização em A Conquista}

Espiritual (1639), de Antonio Ruiz de

199 Montoya e na Festa de S. Lourenço (1587), de José de Anchieta 199

Silvio Ruiz Paradiso 
Configurações do mal no romance Caim,

215 de José Saramago

Hudson Marques da Silva

Vivendo na morte: a História dos

225 Vampiros e seu lugar na cultura popular Iliane Tecchio

O Horror na Literatura Gótica e Fantástica:

239 uma breve excursão de sua gênese à sua contemporaneidade

Rhuan Felipe Scomaçao da Silva

A representação do Diabo no conto $A$ Igreja do Diabo de Machado de Assis e no romance Grande Sertão: veredas de Guimarães Rosa Ricardo Gomes da Silva

A Personificação Demoníaca de Deus

263 em "Poemas malditos, gozosos e devotos", de Hilda Hilst

Paullina Lígia Silva Carvalho

O diabo na arte e no imaginário ocidental

277 Antonio Carlos de Melo Magalhães

Eli Brandão da Silva 



\section{Introdução}

Se a última grande obra de Lúcifer é transformar-se em mero ser de papel, Consummatum est. Imprimatur!

Nomodiabopadrofilhospritossantamêin!

Salma Ferraz, As Malasartes de Lúcifer.

$\mathrm{Na}$ relação que se estabelece entre os diferentes estilos, gêneros e tradições de textos literários, um dos temas recorrentes é o do demoníaco na literatura, mesmo na literatura que pode ser interpretada como crítica da religião. Seja na literatura antiga, chamada muitas vezes de religiosa, como são os textos da Bíblia, do Alcorão, da Bíblia hebraica e cristã em suas diferentes versões, da vastíssima literatura hebraica fora da circunscrição teológico-literária mais institucional, dos textos denominados apócrifos, etc, seja na literatura considerada não religiosa, a presença do tema do demoníaco e suas mais diversas representações, tais como o diabo, o mal, satanás, o demônio são constantemente retomadas, reescritas, ampliadas, criticadas. Da literatura antiga, o primeiro grande exemplo é o texto bíblico hebraico e cristão, mas também os muitos textos denominados apócrifos, já que não importa aos compiladores nenhum tipo de canonicidade prévia, até porque o canônico manifesta tradições afins a outras tradições consideradas não-canônicas. Além destes textos, este livro acolhe artigos que contemplam textos chamados religiosos ainda não amplamente conhecidos, mas que já tenham recebido ou que possam receber interpretações baseadas na crítica e na teoria da literatura. Abre-se, portanto, a possibilidade de sermos confrontados com textos religiosos em novas versões literárias e culturais. Nas muitas literaturas recentes não faltam exemplo da temática do demoníaco. Assim sendo, o demoníaco não está circunscrito à religião formal e institucional, antes se tornou um tema constitutivo de muitas narrativas literárias, além de fazer parte de imaginários e representações das mais diferentes camadas da cultura brasileira. 
Nesta compilação assumimos a tarefa de trabalhar o tema do demoníaco no chamado texto religioso e no texto literário, ou também na relação entre ambos, ainda que seja necessário e importante destacar que alguns dos textos antigos, denominados de religiosos, sejam em sua constituição, escrita, formação, desenvolvimento e recepção textos literários e, por conseguinte, passíveis de serem compreendidos na vasta história da literatura e a partir de enfoques teóricos da crítica e da teoria da literatura. Os artigos deste livro estarão focados nas diversas manifestações do demoníaco na literatura e poderão ser desenvolvidos e apresentados a partir de textos de diferentes épocas, estilos e gêneros. $O$ foco será o tema, não o período, não o estilo, não o gênero.

Os textos apresentados incluem enfoques teóricos oriundos de correntes como os da intertextualidade, da interdiscursividade, da literatura comparada, de teorias da cultura voltadas para literatura marcada pela oralidade no Brasil, assim como as teorias voltadas para os textos clássicos religiosos, como são os textos bíblicos e os chamados apócrifos. O fundamental será desenvolver leituras e interpretações que garantirão competência e domínio do tema, além de busca de acuidade e profundidade na análise literária, na crítica e na teoria da literatura. Outrossim, é importante destacar que o demoníaco evoca os resquícios do mítico na história do pensamento, ainda que a alusão a ele se dê em esferas não tradicionalmente religiosas, como pode ser o caso do pensamento filosófico e mesmo científico.

O demoníaco permite, portanto, esta fronteira do pensamento, esta linha tênue entre o religioso, o literário, outras formas de criar e desenvolver o pensamento e sedimentar as culturas. Se as figuras do Diabo, de Satanás são figuras tradicionalmente religiosas, em grande parte, cultivadas e interpretadas na história das religiões, o demoníaco, por sua vez, estabelece uma fronteira criativa com essas figurações do mal, mas também continua a constituir a criatividade em outras tradições do pensamento, sem deixar de manter certo vínculo com as muitas formas de sua representação na história da cultura, das civilizações e da religião.

Nestelivroreunimosartigos oriundosdeapresentaçãorealizadas durante o Simpósio O Demoníaco na Literatura realizado durante o $2^{\circ}$ CIELLI - Colóquio Internacional de Estudos Linguísticos e Literários $5^{\circ}$ CELLI - Colóquio de Estudos Linguísticos e Literários 
ocorrido na UEM Universidade Estadual de Maringá entre 13 a 15 de Julho de 2012. São pesquisadores de diversas partes do país e de diferentes Universidades e centros de estudos que se debruçam sobre os estudos comparados entre Teologia e Literatura.

Desde já nossos agradecimentos Nutel, Núcleo de Estudos Comparados da UFSC - Universidade Federal de Santa Catarina, dos quais fazem parte dois compiladores: Salma Ferraz e Raphael Novaresi Leopoldo e, especialmente a UEPB, Universidade Estadual da Paraíba que por meio da atuação de compiladores e Professores Antonio Carlos de Melo Magalhães e Eli Brandão, tornaram possível a publicação deste livro pela Editora da UEPB -EDUEPB.

É diante do sagrado e do demônico que nos quedamos perplexos em nossas lutas e reflexões. O teólogo Paul Tillich, em sua obra Filosofia da Religião de 1925, afirma que o demônico aparece em contraposição ao divino e ambos estão inseridos na esfera do Sagrado: O demônico é o Sagrado precedido por um sinal 'menos': o anti-divino sagrado. Carlos Eduardo Brandão Calvani analisando o pensamento de Tilich, acrescenta que se trata do sagrado negativo, destrutivo. Entretanto, ainda é sagrado, uma vez que provém do mesmo abismo de onde flui a graça.

Antonio Carlos de Melo Magalhães Eli Brandão

Salma Ferraz Raphael Novaresi Leopoldo 



\title{
As bem-aventuranças nas versões de Borges, de Machado de Assis, da Bíblia satânica de Anton Lavey e na versão ao mestre com carinho
}

\author{
Salma Ferraz $(\text { UFSC })^{1}$
}

Conforme Harold Bloom em sua obra Angústia da Influência, "nenhum poeta desde Adão e Satanás fala uma linguagem livre da lavrada de seus precursores" (2002, p. 74).

Mikhail Bakhtin (1895-1975), teórico linguista russo, defende a ideia de que toda a escritura é leitura de um corpus literário anterior e entende o "texto como absorção e réplica a um outro texto..." (apud KRISTEVA, 1974, p. 67, negrito nosso), ou seja, a escritura é entendida como releitura de um corpus literário anterior. O conceito clássico de intertextualidade foi escrito por Julia Kristeva em sua obra Introdução à Semanálise:

[...] segundo a qual a palavra literária não é um ponto (um sentido fixo), mas um cruzamento de superfícies textuais, um diálogo de diversas escrituras: do escritor, do destinatário (ou da personagem), do contexto cultural atual ou anterior. [...] todo texto se constrói como mosaico de citações, todo texto é absorção e transformação de um outro texto. Em lugar da noção de subjetividade,

1 É Professora Associada de Literatura Portuguesa da Universidade Federal de Santa Catarina. Atua na Pós-graduação com a linha de Pesquisa Teopoética - Os Estudos Comparados entre Teologia e Literatura, membro da ALALITE - Associação Latino Americana de Literatura e Teologia, líder do NUTEL - Núcleo de Estudos Comparados entre Teologia e Literatura sediado na UFSC. É autora de diversos livros de teoria e ficção. Florianópolis, Brasil, 2010. E-mail: salmferraz@gmail.com. Home Page: http://teopoetica.sites.ufsc.br/salmaferraz.php 
instala-se a intertextualidade e a linguagem poética lê-se pelo menos como dupla" (1974, p. $62-64$, negrito nosso).

Os textos se relacionam entre si, como um verdadeiro mosaico de citações, um caleidoscópio, na qual textos se misturam a outros textos oriundos de mil lugares e culturas diferentes. O leitor deve ter competência para manejar esse caleidoscópio e descobrir a origem, a intersecção, a contaminação deles. O intertexto pode ocorrer por meio de epígrafes, paráfrases, citações, paródias, pastiches etc. A tradição é retomada, exaltada, relativizada e, por vezes, até negada. É isto que acontece com um dos textos bíblicos mais conhecidos do ocidente: $A s$ Bem-aventuranças.

As Bem-aventuranças proclamadas por Jesus no Sermão da Montanha e relatadas no Evangelho de Mateus 5, são, de certa forma, um espécie de contraponto aos Dez Mandamentos recebidos por Moisés no Monte Sinai, relatado no Livro do Êxodo 20:1-17. Os Dez Mandamentos foram proclamados por YHWH, um Deus tribal do panteão cananeu que com o tempo, com a história e política da reforma do Rei de Judá - Josias (639-586) - um nobre sucessor de Moisés, Josué e Davi, na versão teológica do deuteronomista, transforma-se num deus nacional. A partir de Jesus, filho de YHWH do hebraico הוהי, um judeu que viveu e atuou na periferia do poder, portanto, um judeu marginal, na feliz colocação de John P. Meier em seu livro Um Judeu Marginal, surge um movimento que incomoda os romanos, com Paulo chega a Roma e com o Cristianismo alcança o mundo. Jesus, que não conheceu a palavra Cristo

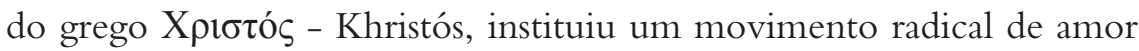
ao próximo o que poderíamos denominar de Jesuísmo. J. B. Libânio afirma que

O termo Cristianismo não se origina de Jesus, mas de Cristo. Não é o camponês e artesão Jesus que viveu na Palestina no primeiro século de nossa era que criou um movimento e o propagou pelas regiões circunvizinhas. Não nasceu um jesuanismo. [...] O Cristianismo é a forma histórica que o movimento de Jesus assumiu. (2008, p. 16) 
O autor ainda firma que o Cristianismo foi a reinterpretação do Jesus da Palestina, feita pelos seus seguidores após a sua morte, com isto "o movimento de Jesus deixa a Palestina e se espalha pelo mundo." (LIBÂNIO, 2008, p. 48). Aventamos a hipótese de que talvez pudesse ter existido um Jesuísmo baseado no Jesus palestinense sem o Cristianismo, mas o Cristianismo não existiria sem aquele. O Evangelho de João, capítulo 1:1, define este Jesus nazareno que vivia às margens da sociedade, com os párias e pecadores como o filho de Deus: "No princípio era o Verbo e o verbo estava com Deus e o Verbo era Deus."

Sobre o sucesso absoluto de YHVH, o Deus tribal cananeu, o Senhor dos Exércitos, Guerra Junqueira (1850-1923) no controvertido Prefácio à Segunda Edição de $A$ Velhice do Padre Eterno, afirma polemicamente:

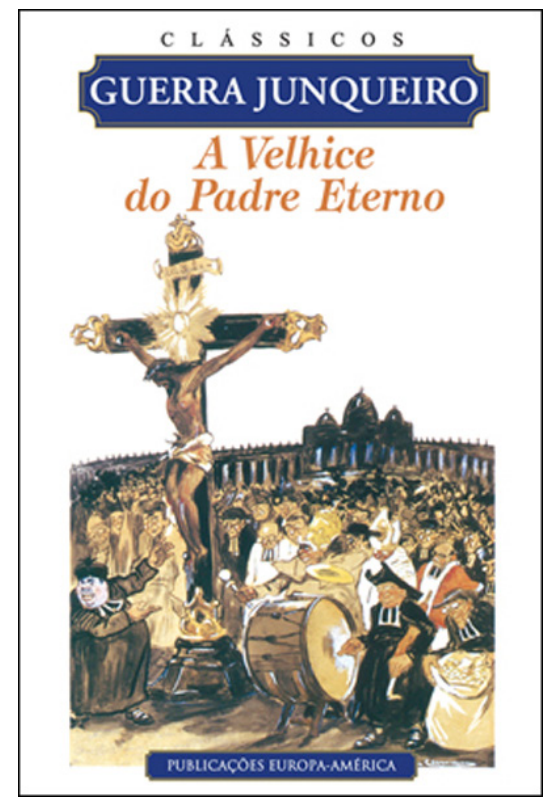

Fig. 1. A velhice do Padre Eterno I

Qual é o homem civilizado do nosso tempo que deseje ir para o Céu de Jeová, de asas brancas nas costas, desferir uma harpa ou tanger uma citara, à roda do trono do Senhor, na beatitude eterna, per omnia secula seculorum [...]. 
Do Horeb, do Gólgota e do Vaticano, trilogia espantosa, que fizeste? [...]

A acusação ai está. Agora, a defesa. Morreu o Padre Eterno? Não. Apesar de contar seis mil anos de idade e de ter já feito, à cautela, dois Testamentos, esse velho Sr. Deus dos Exércitos está ainda muito bem disposto a enterrar-nos a nós todos e aos nossos descendentes, durante esta meia dúzia de séculos mais chegados.

Tem catorze fôlegos este demónio deste Deus. Quantos colegas dele em divindade, que vieram depois, não dormem já esquecidos e extintos no grande campo-santo da mitologia, onde estão enterradas com eles no eterno silêncio as mais belas e supremas aspirações da consciência humana!

Confesso-o. Causa-me horror o Deus sanguinolento e fúnebre que separou o homem da Natureza, - que disse ao filho: Cospe em tua mãe!

No entanto, reconheço-o, de todos os Deuses existentes é Jeová quem ocupa ainda no Céu Largo das Religiões o mais belo e sumptuoso dos palácios. Brama e Buda vivem menos mal, mas no fim de contas são dois criados de servir da Rússia e da Inglaterra e portanto de Jeová, - Pai e Filho.

Quem diria que este truculento Sr. Padre Eterno, um pobre Deus semita, desprotegido e bárbaro, um Deus de $4^{\mathrm{a}}$ ou $5^{\mathrm{a}}$ classe, havia de fazer uma carreira tão longa e tão brilhante! Ele, que conhecera Júpiter TodoPoderoso, dominando o Olimpo e trovejando lá de cima: - «O universo sou eu!» - quando havia de supor que o grande Deus helénico morreria tão depressa, deixando-lhe o seu Versalhes sabrenatural, dum luxo quimérico, para ele instalar a sua corte desgrenhada e mística, de profetas selvagens e de anacoretas cavernosos, calcando uma face de luar e de olhos azuis, húmidos de esperança, fitos na última lágrima da noite - que é a primeira estrela da manhã! 
Teve sorte o velhote! Ele, que habitou lá em cima uma vetusta trapeira desconhecida e infecta, acharse de repente nas Tulherias dos Deuses, no Olimpo! Que delícia! O Criador selvagem, o Átila furibundo, castrado e piolhoso, ver-se de surpresa no luxo resplandecente da Grécia de Alexandre e da Roma dos Césares! Job em casa de Lúculo! Ezequiel à mesa de Vitélio! Ah, na primeira noite em que o Deus dos Exércitos dormiu na cama de Júpiter - Sardanápalo, ele achou naturalmente bem preferível as molezas lúbricas da Assíria e da Pérsia aos areais flamejantes do seu deserto, aos basaltos calcinados da sua recozida Palestina!

Civilizou-se. Ao deitar-se, era ainda um bárbaro; quando se levantou, era já um corrupto.

Nessa primeira noite de Olimpo, Jeová não pregou olho, decerto.

Era natural. O Deus de Jerusalém, castrado, feroz, porco, cheirando a alho, um Deus cujo reino, na geografia celeste, tinha as dimensões do principado de Mónaco, encontra-se subitamente no trono de Júpiter, César todo dominador de tudo quanto existia - porque tudo fora feito por ele! (2012, p. 1-7)

O que Guerra Junqueira revive com sua crítica ácida e panfletária, já estava presente no Herege Mor Marcião de Sínope (85-160), talvez o mais brilhante herege do cristianismo primitivo, que ao definir o seu Cânon, simplesmente não aceitava o Velho Testamento, porque considerava o YHWH muito violento e sanguinário. Para Marcião eram dois deuses completamente diferentes, não havia nenhuma evolução de um Deus guerreiro, O Senhor dos Exércitos, para um Deus Bom, encarnado na figura de Jesus, O Filho do Homem. A partir desta postura do arqui -herege Marcião a Igreja foi forçada a definir o seu cânon. É Jack Miles na Introdução do seu livro Deus, uma Biografia, quem afirma: "É estranho dizer isso, mas Deus não é nenhum santo.” (1997, p. 17). Marcião morreu como herege ao defender esta tese. Interessante constatarmos que José Saramago (1922-2010) o Nobel de Literatura de 1998, também não aceitava esta evolução. Basta lermos O Evangelho segundo Jesus Cristo (1991) e Caim (2009). Sem sombra de dúvidas, na obra inteira de 
Saramago, especificamente nestes dois romances o alvo é YHWY. Se no Evangelho segundo Jesus Cristo, mata definitivamente Deus, em Caim, o autor português crema as cinzas do Senhor das Guerras do Judaísmo.

Guerra Junqueira faz de seu livro um libelo denunciando as mazelas da Igreja Católica. É um anticlericalista ferrenho. Vale a pena observamos a ilustração acima. da capa publicada pela Edições Europa América. O Vaticano é transformado num picadeiro, quase um circo romano e Jesus aparece ali quase como uma palhaço mor observando a banda de clérigos, extasiada, passar. Observemos abaixo mais uma ilustração deste livro. A ilustração abaixo diz tudo: Cruz e Espada, juntas no domínio do mundo.

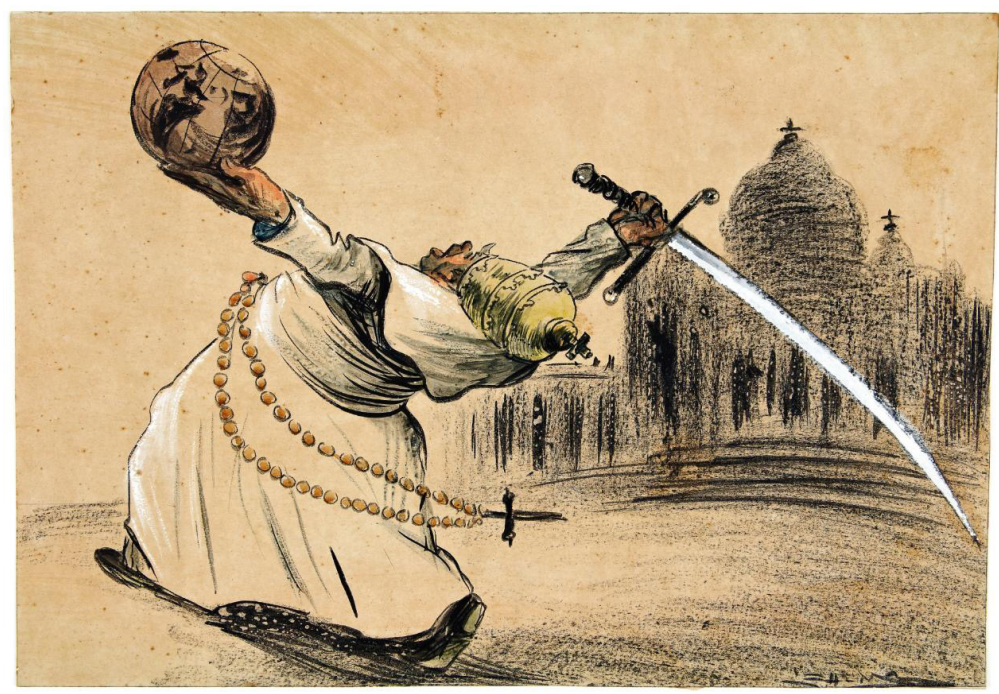

Fig. 2. A Velhice co Padre Eterno II

\section{É YHWH, quem no Monte Sinai, dá a Moisés os Dez} Mandamentos, um decálogo duro de cumprir, que apresenta mais negativas ou uma infinidade de nãos. É o próprio decálogo do não, conforme grifamos no texto abaixo: 
Os Dez Mandamentos - Êxodo 20. 1 a 17

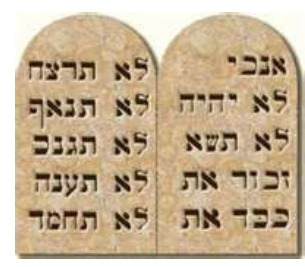

Fig. 3. Os Dez Mandamentos

1 - Então falou Deus todas estas palavras, dizendo: Eu sou o Senhor teu Deus, que te tirei da terra do Egito, da casa da servidão. Não terás outros deuses diante de mim.

2 - Não farás para ti imagem de escultura, nem alguma semelhança do que há em cima nos céus, nem em baixo na terra, nem nas águas debaixo da terra. Não te encurvarás a elas nem as servirás; porque eu, o Senhor teu Deus, sou Deus zeloso, que visito a iniqüidade dos pais nos filhos, até a terceira e quarta geração daqueles que me odeiam. E faço misericórdia a milhares dos que me amam e aos que guardam os meus mandamentos.

3 - Não tomarás o nome do Senhor teu Deus em vão; porque o Senhor não terá por inocente o que tomar o seu nome em vão.

4 - Lembra-te do dia do sábado, para o santificar. Seis dias trabalharás, e farás toda a tua obra. Mas o sétimo dia é o sábado do Senhor teu Deus; não farás nenhuma obra, nem tu, nem teu filho, nem tua filha, nem o teu servo, nem a tua serva, nem o teu animal, nem o teu estrangeiro, que está dentro das tuas portas. Porque em seis dias fez o Senhor os céus e a terra, o mar e tudo que neles há, e ao sétimo dia descansou; portanto abençoou o Senhor o dia do sábado, e o santificou.

5 - Honra a teu pai e a tua mãe, para que se prolonguem os teus dias na terra que o Senhor teu Deus te dá. 
6 - Não matarás.

7 - Não adulterarás.

8 - Não furtarás.

9 - Não dirás falso testemunho contra o teu próximo.

10 - Não cobiçarás a casa do teu próximo, não cobiçarás a mulher do teu próximo, nem o seu servo, nem a sua serva, nem o seu boi, nem o seu jumento, nem coisa alguma do teu próximo.

São exatos dez não, é própria aliança do não, das proibições. Quão dificil é para os simples mortais viverem debaixo da Lei, mas Dura lex sed lex. O Deus Guerreiro dos judeus não conhecia a letra de música de Caetano Veloso É Proibido Proibir: E eu digo não/E eu digo não ao não/ eu digo É!/ Proibido proibir!

Observemos agora As Bem-aventuranças, contidas no Sermão da Montanha, relatadas no Evangelho Segundo São Mateus 5:1-48, na Versão da Bíblia realizada por João Ferreira de Almeida:

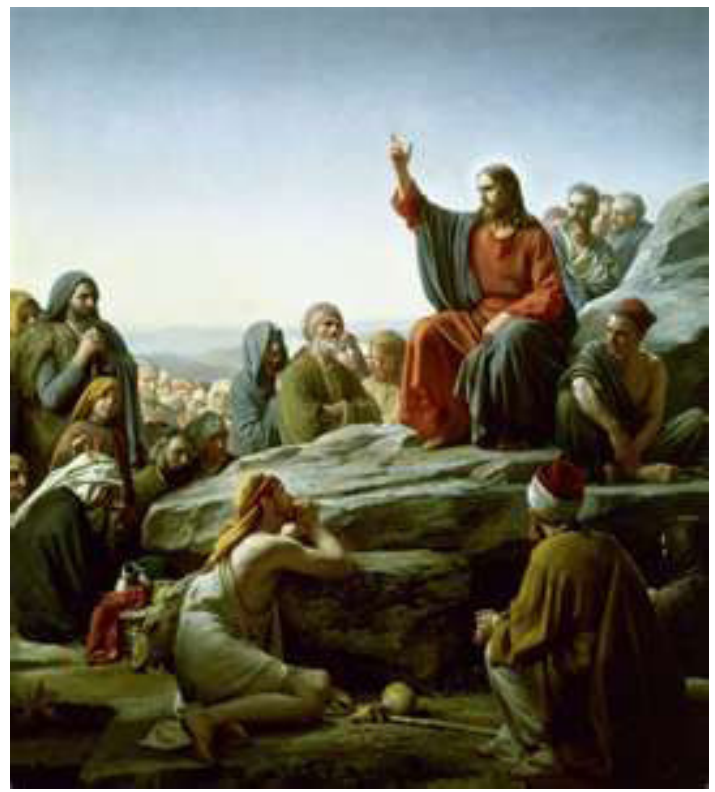

Fig. 4. Sermão da Montanha 
E Jesus, vendo a multidão, subiu a um monte, e, assentando-se, aproximaram-se dele os seus discípulos;

E, abrindo a sua boca, os ensinava, dizendo:

Bem-aventurados os pobres de espírito, porque deles é o reino dos céus;

Bem-aventurados os que choram, porque eles serão consolados;

Bem-aventurados os mansos, porque eles herdarão a terra;

Bem-aventurados os que têm fome e sede de justiça, porque eles serão fartos;

Bem-aventurados os misericordiosos, porque eles alcançarão misericórdia;

Bem-aventurados os limpos de coração, porque eles verão a Deus;

Bem-aventurados os pacificadores, porque eles serão chamados filhos de Deus;

Bem-aventurados os que sofrem perseguição por causa da justiça, porque deles é o reino dos céus;

Bem-aventurados sois vós, quando vos injuriarem e perseguirem e, mentindo, disserem todo o mal contra vós por minha causa.

Exultai e alegrai-vos, porque é grande o vosso galardão nos céus; porque assim perseguiram os profetas que foram antes de vós.

Vós sois o sal da terra; e se o sal for insípido, com que se há de salgar? Para nada mais presta senão para se lançar fora, e ser pisado pelos homens.

Vós sois a luz do mundo; não se pode esconder uma cidade edificada sobre um monte;

Nem se acende a candeia e se coloca debaixo do alqueire, mas no velador, e dá luz a todos que estão na casa. 
Assim resplandeça a vossa luz diante dos homens, para que vejam as vossas boas obras e glorifiquem a vosso Pai, que está nos céus.

Não cuideis que vim destruir a lei ou os profetas: não vim ab-rogar, mas cumprir.

\section{Porque em verdade vos digo que, até que o céu e a terra passem, nem um jota ou um til se omitirá da lei, sem que tudo seja cumprido.}

Qualquer, pois, que violar um destes mandamentos, por menor que seja, e assim ensinar aos homens, será chamado o menor no reino dos céus; aquele, porém, que os cumprir e ensinar será chamado grande no reino dos céus.

Porque vos digo que, se a vossa justiça não exceder a dos escribas e fariseus, de modo nenhum entrareis no reino dos céus.

Ouvistes que foi dito aos antigos: Não matarás; mas qualquer que matar será réu de juízo.

Eu, porém, vos digo que qualquer que, sem motivo, se encolerizar contra seu irmão, será réu de juízo; e qualquer que disser a seu irmão: Raca, será réu do sinédrio; e qualquer que lhe disser: Louco, será réu do fogo do inferno.

Portanto, se trouxeres a tua oferta ao altar, e aí te lembrares de que teu irmão tem alguma coisa contra ti,

Deixa ali diante do altar a tua oferta, e vai reconciliar-te primeiro com teu irmão e, depois, vem e apresenta a tua oferta.

Concilia-te depressa com o teu adversário, enquanto estás no caminho com ele, para que não aconteça que o adversário te entregue ao juiz, e o juiz te entregue ao oficial, e te encerrem na prisão.

Em verdade te digo que de maneira nenhuma sairás dali enquanto não pagares o último ceitil.

Ouvistes que foi dito aos antigos: Não cometerás adultério. 
$\mathrm{Eu}$, porém, vos digo, que qualquer que atentar numa mulher para a cobiçar, já em seu coração cometeu adultério com ela.

Portanto, se o teu olho direito te escandalizar, arranca-o e atira-o para longe de ti; pois te é melhor que se perca um dos teus membros do que seja todo o teu corpo lançado no inferno.

$\mathrm{E}$, se a tua mão direita te escandalizar, corta-a e atira-a para longe de ti, porque te é melhor que um dos teus membros se perca do que seja todo o teu corpo lançado no inferno.

Também foi dito: Qualquer que deixar sua mulher, dê-lhe carta de desquite.

Eu, porém, vos digo que qualquer que repudiar sua mulher, a não ser por causa de prostituição, faz que ela cometa adultério, e qualquer que casar com a repudiada comete adultério.

Outrossim, ouvistes que foi dito aos antigos: Não perjurarás, mas cumprirás os teus juramentos ao Senhor.

Eu, porém, vos digo que de maneira nenhuma jureis; nem pelo céu, porque é o trono de Deus;

Nem pela terra, porque é o escabelo de seus pés; nem por Jerusalém, porque é a cidade do grande Rei;

Nem jurarás pela tua cabeça, porque não podes tornar um cabelo branco ou preto.

Seja, porém, o vosso falar: Sim, sim; Não, não; porque o que passa disto é de procedência maligna.

Ouvistes que foi dito: Olho por olho, e dente por dente.

Eu, porém, vos digo que não resistais ao mal; mas, se qualquer te bater na face direita, oferece-lhe também a outra;

E, ao que quiser pleitear contigo, e tirar-te a túnica, larga-lhe também a capa; 
E, se qualquer te obrigar a caminhar uma milha, vai com ele duas.

Dá a quem te pedir, e não te desvies daquele que quiser que the emprestes.

Ouvistes que foi dito: Amarás o teu próximo, e odiarás o teu inimigo.

Eu, porém, vos digo: Amai a vossos inimigos, bendizei os que vos maldizem, fazei bem aos que vos odeiam, e orai pelos que vos maltratam e vos perseguem; para que sejais filhos do vosso Pai que está nos céus;

Porque faz que o seu sol se levante sobre maus e bons, e a chuva desça sobre justos e injustos.

Pois, se amardes os que vos amam, que galardão tereis? Não fazem os publicanos também o mesmo?

E, se saudardes unicamente os vossos irmãos, que fazeis de mais? Não fazem os publicanos também assim?

Sede vós pois perfeitos, como é perfeito o vosso Pai que está nos céus." (Versão eletrônica, negritos nossos)

Citamos uma parte a mais do Sermão da Montanha dada a sua rara beleza! Não queremos passar nenhum sermão aqui, mas este texto é mais do necessário neste mundo doente, hospedado numa UTI, de tanta frieza, maldade, ostentação, falta de amor, em que muitos se curvam para o solo, só vêm a si e seu umbigo, não veem o próximo, em que muitos já morreram, apenas não foram avisados disto. Voltando ao texto e nos desculpando o sermão em cima do sermão, centremos nossa análise no núcleo do Sermão da Montanha - As Bem- Aventuranças. Não existe não. Ao decálogo do não do Sinai, opõem-se o decálogo do Bem, da felicidade. Na Bíblia de Jerusalém o adjetivo Bem-Aventurados da versão Almeida é substituído pelo adjetivo felizes: 
Felizes os pobres no espírito, porque deles é o Reino dos Céus.

Felizes os mansos, porque herdarão a terra.

Felizes os aflitos, porque serão consolados.

Felizes os que têm fome e sede de justiça, porque serão saciados.

Felizes os que são misericordiosos, porque alcançarão misericórdia.

Felizes os puros no coração, porque verão a Deus.

Felizes os que promovem a paz, porque serão chamados filhos de Deus.

Felizes os que são perseguidos por causa da justiça, porque deles é o Reino do céu.

Felizes sois, quando vos injuriarem e vos perseguirem, e, mentindo, disserem todo o mal contra vós, por causa de mim.

Alegrai-vos e regozijai-vos, porque será grande a vossa recompensa nos céus. para vocês a recompensa no céus. Pois foi assim que perseguiram os profetas que vieram antes de vós." (2011, Mt $5: 3-12)$

Embora, Jesus afirme que nem um jota ou um til passará da lei, os seus conselhos são radicalmente mais leves que dura Lei de YHWH. O Sermão da Montanha tem uma suavidade, humanidade e positivismo que o Decálogo do Sinai em absoluto não tinha.

Talvez seja esta suavidade, este tom de conselho e autoajuda, foi que fez e faz com que o Sermão da Montanha seja muito mais parodiado na Literatura do que os Dez Mandamentos. Não é fácil brincar com YHWH! Georges Minois em História do Riso e do Escárnio afirma “... o riso não é natural no cristianismo, religião séria por excelência. [...] Do que poderia rir um Ser todo poderoso, perfeito, que se basta a si mesmo, sabe tudo, vê tudo e pode tudo?” (2003, p. 111). Genialmente Minois nos faz acreditar em sua tese, até a metade do livro, quando debocha do leitor e diz: há muito riso na Bíblia e próprio YHWH ri de seus inimigos. Mas o que nos interessa foi que esta imagem de um cristianismo sério foi que pesou no ocidente: basta observamos que a imagem que ficou como ícone 
maior deste movimento que mudou radicalmente a face do ocidente foi o Cristo assustadoramente sofredor na Cruz e não sua imagem tranquila e poderosa, ressurreto vencendo a morte. O Filme A Paixão de Cristo (2004) de Mel Gibson é uma elegia ao sofrimento e ao sangue, parece um filme de terror. Escorre sangue da tela e a ressurreição ocupa menos de 2 segundo no final. $O$ filme foi um estrondoso sucesso, cristãos de todas as denominações assistiam o filme em suas próprias igrejas e choravam, choravam, quase lágrimas de sangue.

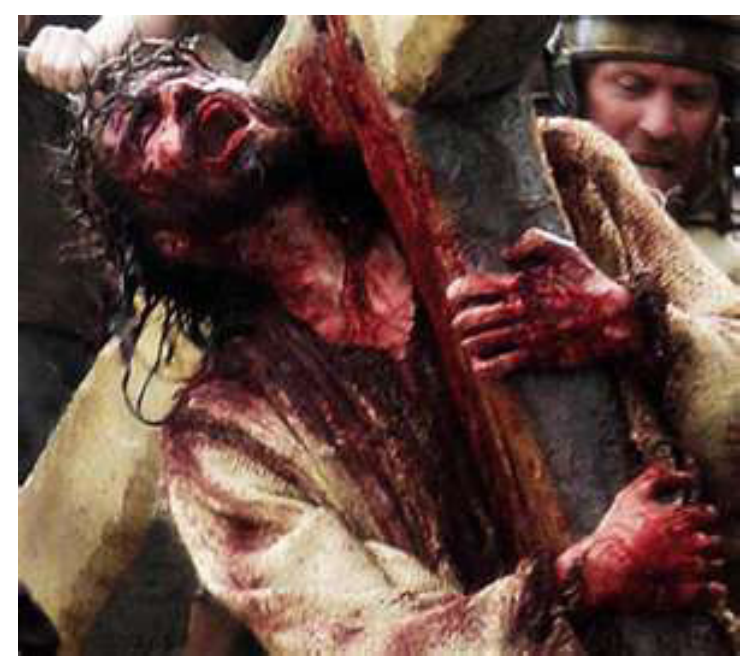

Fig. 5. A Paixão de Cristo (שי לש וויספה), Mel Gibson (2004)

Há necessidade de se ter coragem para brincar com o Senhor dos Exércitos, o Eu sou o que Sou do Judaísmo. Lembramos aqui a magnífica paródia dos Simpsons aos Dez Mandamentos, na segunda temporada apresentada em 1991, no episódio intitulado Homer contra Lisa e o 8. Mandamento, parodiando o filme Os Dez Mandamentos (1956), de Cecil B Demille.

Analisemos a seguir a divertida paródia Ao Sermão da Montanha, de Machado de Assis (1839-1908), publicado na Gazeta de Notícias em 1892. 


\section{O Sermão do Diabo}

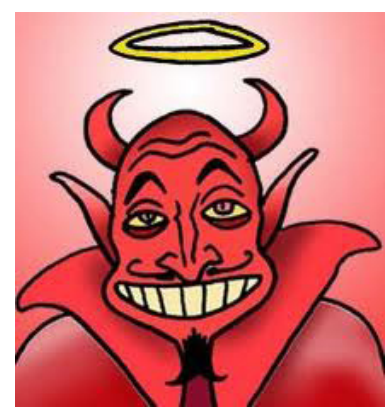

Fig. 6. O Diabo

Nem sempre respondo por papéis velhos: mas aqui está um que parece autêntico; e, se o não é, vale pelo texto, que é substancial. É um pedaço do evangelho do Diabo, justamente um sermão da montanha, à maneira de São Mateus. Não se apavorem as almas católicas. Já Santo Agostinho dizia que "a igreja do Diabo imita a igreja de Deus". Daí a semelhança entre os dois evangelhos. Lá vai o do Diabo:

"E vendo o Diabo a grande multidão de povo, subiu a um monte, por nome Corcovado, e, depois de se ter sentado, vieram a ele os seus discípulos.

E ele, abrindo a boca, ensinou dizendo as palavras seguintes.

Bem-aventurados aqueles que embaçam, porque eles não serão embaçados.

Bem-aventurados os afoitos, porque eles possuirão a terra.

Bem-aventurados os limpos das algibeiras, porque eles andarão mais leves.

Bem-aventurados os que nascem finos, porque eles morrerão grossos.

Bem-aventurados sois, quando vos injuriarem e disserem todo o mal, por meu respeito. 
Folgai e exultai, porque o vosso galardão é copioso na terra.

Vós sois o sal do money market. E se o sal perder a força, com que outra coisa se há de salgar?

Vós sois a luz do mundo. Não se põe uma vela acesa debaixo de um chapéu, pois assim se perdem o chapéu e a vela.

Não julgueis que vim destruir as obras imperfeitas, mas refazer as desfeitas.

Não acrediteis em sociedades arrebentadas. Em verdade vos digo que todas se consertam, e se não for com remendo da mesma cor, será com remendo de outra cor.

Ouvistes que foi dito aos homens: Amai-vos uns aos outros. Pois eu digo-vos: Comei-vos uns aos outros; melhor é comer que ser comido; o lombo alheio é muito mais nutritivo que o próprio.

Também foi dito aos homens: Não matareis a vosso irmão, nem a vosso inimigo, para que não sejais castigados. Eu digo-vos que não é preciso matar a vosso irmão para ganhardes o reino da terra; basta arrancar-lhe a última camisa.

Assim, se estiveres fazendo as tuas contas, e te lembrar que teu irmão anda meio desconfiado de ti, interrompe as contas, sai de casa, vai ao encontro de teu irmão na rua, restitui-lhe a confiança, e tira-lhe o que ele ainda levar consigo.

Igualmente ouvistes que foi dito aos homens: Não jurareis falso, mas cumpri ao Senhor os teus juramentos.

Eu, porém, vos digo que não jureis nunca a verdade, porque a verdade nua e crua, além de indecente, é dura de roer; mas jurai sempre e a propósito de tudo, porque os homens foram feitos para crer antes nos que juram falso, do que nos que não juram nada. Se disseres que o sol acabou, todos acenderão velas. 
Não façais as vossas obras diante de pessoas que possam ir contá-lo à polícia.

Quando, pois, quiserdes tapar um buraco, entendei-vos com algum sujeito hábil, que faça treze de cinco e cinco.

Não queirais guardar para vós tesouros na terra, onde a ferrugem e a traça os consomem, e donde os ladrões os tiram e levam.

Mas remetei os vossos tesouros para algum banco de Londres, onde a ferrugem, nem a traça os consomem, nem os ladrões os roubam, e onde ireis vê-los no dia do juízo.

Não vos fieis uns nos outros. Em verdade vos digo, que cada um de vós é capaz de comer o seu vizinho, e boa cara não quer dizer bom negócio.

Vendei gato por lebre, e concessões ordinárias por excelentes, a fim de que a terra se não despovoe das lebres, nem as más concessões pereçam nas vossas mãos.

Não queirais julgar para que não sejais julgados; não examineis os papéis do próximo para que ele não examine os vossos, e não resulte irem os dous para a cadeia, quando é melhor não ir nenhum.

Não tenhais medo às assembléias de acionistas, e afagai-as de preferência às simples comissões, porque as comissões amam a vangloria e as assembléias as boas palavras.

As porcentagens são as primeiras flores do capital; cortai-as logo, para que as outras flores brotem mais viçosas e lindas.

Não deis conta das contas passadas, porque passadas são as contas contadas, e perpétuas as contas que se não contam.

Deixai falar os acionistas prognósticos; uma vez aliviados, assinam de boa vontade. 
Podeis excepcionalmente amar a um homem que vos arranjou um bom negócio; mas não até o ponto de o não deixar com as cartas na mão, se jogardes juntos.

Todo aquele que ouve estas minhas palavras, e as observa, será comparado ao homem sábio, que edificou sobre a rocha e resistiu aos ventos; ao contrário do homem sem consideração, que edificou sobre a areia, e fica a ver navios..."

Aqui acaba o manuscrito que me foi trazido pelo próprio Diabo, ou alguém por ele; mas eu creio que era o próprio. Alto, magro, barbícula ao queixo, ar de Mefistófeles. Fiz-lhe uma cruz com os dedos e, ele sumiu-se. Apesar de tudo, não respondo pelo papel, nem pelas doutrinas, nem pelos erros de cópia. (versão on-line, 2012)

Machado de Assis, em seu texto diabólico, parodia São Mateus e humoristicamente faz o seu Sermão do Diabo. E onde mais o Diabo poderia realizar seu Sermão profano senão no Brasil, senão no Corcovado, senão no Rio de Janeiro, terra das mulatas e do carnaval! Se Deus é brasileiro, o Diabo também o é. Em seu livro O Diabo nos porões da caravela, a crítica Iza Gomes Chain realiza um estudo sobre a influência das crenças do povo português no Brasil recém-descoberto, principalmente no que diz respeito às figuras centrais do cristianismo. Lendo seu livro e suas pertinentes observações, podemos dizer que o brasileiro, ao assimilar o arcabouço mental português, misturado com as crenças africanas e indígenas, desteologizou o Diabo. O Diabo não mete medo em ninguém passa a ser quase um membro da família brasileira, traquino e astuto, basta ver as seguintes imprecações comuns em todo o Brasil: Oh! diacho, menino encapetado, endiabrado, o diabo que te carregue, sai deste corpo que não te pertence, etc. Machado poderia ter incluído, ou melhor, repetido no seu Sermão do Diabo, uma fala genial presente no conto A Igreja do Diabo, publicado em 1884. O Diabo, cansado de viver na periferia do Cristianismo, e viver somente das sobras de Deus e do Céu, resolve fundar sua própria Igreja. Uma de suas principais regras e máximas é: "Leve a breca o próximo! Não há próximo! A única hipótese 
em que ele permitia amar ao próximo era quando se tratasse de amar as damas alheias, porque essa espécie de amor tinha a particularidade de não ser outra coisa mais do que o amor do indivíduo a si mesmo." (versão on-line 2012, negrito nosso)

Já o escritor argentino Jorge Luis Borges (1899-1986), um dos maiores representantes da literatura latino americana, tinha como um de suas temáticas preferidas o diálogo intertextual com a Bíblia, com o Judaísmo e o Cristianismo. Este aspecto já foi devidamente explorado em livros e centenas de artigos. Contemplemos esta sutileza de obra de arte parodística de Borges intitulada Fragmentos de um Evangelio Apócrifo, extraído do livro Elogio da Sombra, publicado em 1969. Com toda tradução é uma última análise uma traição, citamos no original.

\section{Fragmentos de um Evangelio apócrifo}

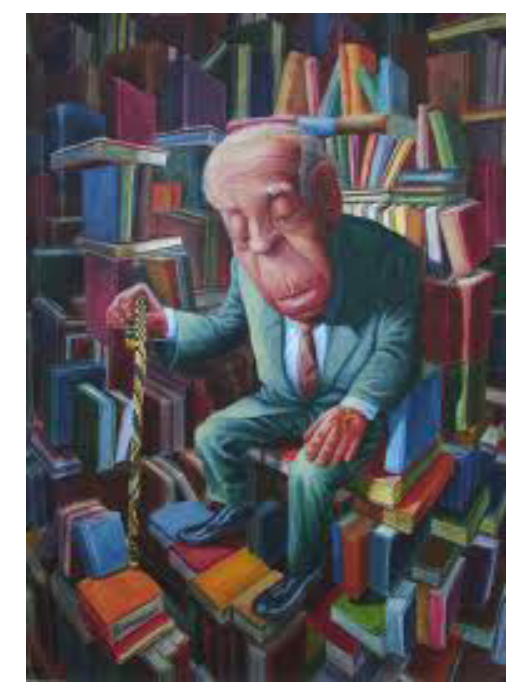

Fig. 7. Jorge Luiz Borges e sua biblioteca

Desdichado el pobre en espíritu, porque bajo la tierra será lo que ahora es en la tierra.

Desdichado el que llora, porque ya tiene el hábito miserable del llanto.

Dichosos los que saben que el sufrimiento no es una corona de gloria.

No basta ser el último para ser alguna vez el primero. 
Feliz el que no insiste en tener razón, porque nadie la tiene o todos la tienen.

Feliz el que perdona a los otros y el que se perdona a sí mismo.

Bienaventurados los mansos, porque no condescienden a la discordia.

Bienaventurados los que no tienen hambre de justicia, porque saben que nuestra suerte, adversa o piadosa, es obra del azar, que es inescrutable.

Bienaventurados los misericordiosos, porque su dicha está en el ejercicio de la misericordia y no en la esperanza de un premio.

Bienaventurados los de limpio corazón, porque ven a Dios.

Bienaventurados los que padecen persecución por causa de la justicia, porque les importa más la justicia que su destino humano.

Nadie es la sal de la tierra, nadie, en algún momento de su vida, no lo es.

Que la luz de una lámpara se encienda, aunque ningún hombre la vea. Dios la verá.

No hay mandamiento que no pueda ser infringido, y también los que digo y los que los profetas dijeron. El que matare por la causa de la justicia, o por la causa que él cree justa, no tiene culpa.

Los actos de los hombres no merecen ni el fuego ni los cielos.

No odies a tu enemigo, porque si lo haces, eres de algún modo su esclavo. Tu odio nunca será mejor que tu paz.

Si te ofendiere tu mano derecha, perdónala; eres tu cuerpo y eres tu alma y es arduo, o imposible, fijar la frontera que los divide...

No exageres el culto de la verdad; no hay hombre que al cabo de un día, no haya mentido con razón muchas veces.

No jures, porque todo juramento es un énfasis. 
Resiste al mal, pero sin asombro y sin ira. A quien te hiriere en la mejilla derecha, puedes volverle la otra, siempre que no te mueva el temor.

Yo no hablo de venganza ni de perdones; el olvido es la única venganza y el único perdón. Hacer el bien a tu enemigo puede ser obra de justicia y no es arduo; amarlo, tarea de ángeles y no de hombres.

Hacer el bien a tu enemigo es el mejor modo de complacer tu vanidad.

No acumules oro en la tierra, porque el oro es padre del ocio, y éste, de la tristeza y el tedio.

Piensa que los otros son justos y lo serán, y si no es así, no es tuyo el error.

Dios es más generoso que los hombres y los medirá con otra medida.

Da lo santo a los perros, echa tus perlas a los puercos; lo que importa es dar.

Busca por el agrado de buscar, no por el de encontrar...

La puerta es la que elige, no el hombre.

No juzgues al árbol por sus frutos ni al hombre por sus obras; pueden ser peores o mejores.

Nada se edifica sobre la piedra, todo sobre la arena, pero nuestro deber es edificar como si fuera piedra la arena...

Feliz el pobre sin amargura o el rico sin soberbia.

Felices los valientes, los que aceptan con ánimo parejo la derrota o las palmas.

Felices los que guardan en la memoria palabras de Virgilio o de Cristo, porque éstas darán a luz a sus días.

Felices los amados y los amantes y los que pueden prescindir del amor.

Felices los felices. (versão on-line, 2012, negritos nossos) 
Borges suaviza ainda mais o já suave Sermão da Montanha. Eis aqui a riqueza da Bíblia que funciona como um arca que sempre pode ser saqueada por todos os escritores de todos os tempos. Não há temas novos, mas o gênio sabe saquear o que veio antes dele e deixar a sua assinatura. Se Jesus revoluciona o judaísmo com seu Sermão da Montanha, suas bem-aventuranças, Borges a partir do texto de Jesus, efetiva suas Bemaventuranças Apócrifas. Mas aqui Apócrifo é usado no sentido primeiro do grego $\alpha \pi$ óкрvфо ; do latim apócryphus, vertido para português no sentido de oculto, não de falso, como vulgarmente o termo passou a designar. Borges humaniza mais ainda o Sermão da Montanha, que na sua versão poderia ser denominada de Sermão do Humano, porque compreende que certas coisas só são possíveis a anjos, não a humanos. Ao não mentirás cristão, Borges diz que não há um homem que ao cabo de um dia não tenha proferido uma mentira sequer. Jesus relê o Velho Testamento: "Ouvistes que foi dito: Amarás o teu próximo, e odiarás o teu inimigo. Eu, porém, vos digo: Amai a vossos inimigos, bendizei os que vos maldizem, fazei bem aos que vos odeiam, e orai pelos que vos maltratam..." (Mateus 5: 20). Mas Borges relê Jesus ampliando mais ainda a sua condescendência com os humanos: "Hacer el bien a tu enemigo puede ser obra de justicia y no es arduo; amarlo, tarea de ángeles y no de hombres." Jesus, filho de Deus e de uma humana, portanto, Deus e Homem, nos aconselha amar os nossos inimigos. Já Borges sendo só humano nos desculpa e afirma que amar os inimigos é obra de anjos e nós não somos anjos, somos apenas e miseravelmente homens. É muito para nós!

Seu Sermão do Humano é generoso demais. Enquanto o Evangelista Mateus afirma em seu livro capítulo 7:6 - "Não deis aos cães as coisas santas, nem deis aos porcos as vossas pérolas, não aconteça que as pisem com os pés e, voltando-se, vos despedacem.”, Borges caminha a segunda milha: "Da lo santo a los perros, echa tus perlas a los puercos; lo que importa es dar." O pregador argentino termina sua predica com um benção: Felices los felices.

A paródia evangélica encontra sua radicalidade naquilo que denominamos de Mal-Aventuranças, presentes na denominada Bíblia Satânica (The Satanic Bible), um livro escrito pelo autodenominado satanista Anton Szandor LaVey em 1969. La Vey nasceu em Chicago em 1930 e morreu em São Francisco em 1997, tendo fundado a chamada Igreja de Satã (Church of Satan) em Abril de 1966. Sua igreja é anticristã, combate a 
repressão sexual e o sentimento de culpa. Esta Bíblia Satânica contêm uma coleção de ensaios, observações e rituais mágicos que formam o núcleo temático do que ficou conhecido como Satanismo de LaVey, que prioriza Satanás como a força motriz que move a natureza e todos os mundos. Para os satanista de LaVey, o termo é usado no sentido de adversário, e não como o demônio do monoté́smo cristão. Citemos as Mal- Aventuranças da Bíblia Satânica de LaVey:

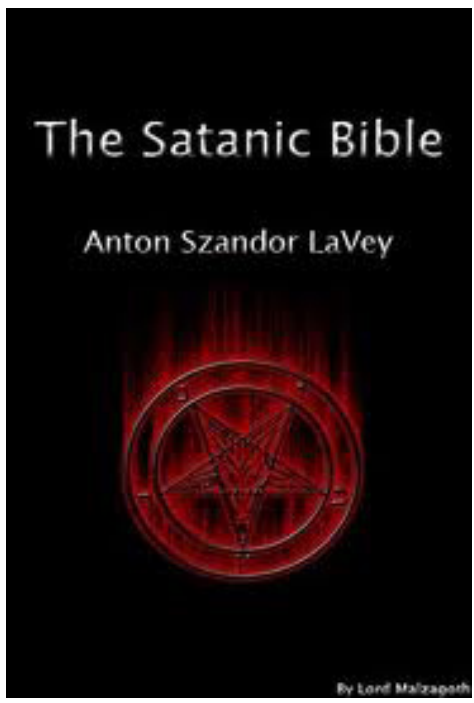

Fig. 8. The Satanic Bible

Abençoados são os fortes, pois eles possuirão a terra - Amaldiçoados são os fracos, pois eles herdarão o jugo!

Abençoados são os poderosos, pois eles serão reverenciados no meio dos homens - Amaldiçoados são os débeis, pois eles serão destruídos!

Abençoados são os corajosos, pois eles serão os mestres do mundo - Amaldiçoados são os submissos na honradez, pois eles serão pisados sobre a representação de Satã!

Abençoados são os vitoriosos, pois a vitória é a base do direito - Amaldiçoados são os conquistados, pois eles serão vassalos para sempre! 
Abençoados são os que usam mão de ferro, pois os ineptos desaparecerão antes deles - Amaldiçoados são os pobres de espírito, pois eles serão cuspidos!

Abençoados são os autodesafiadores, pois seus dias serão longos na terra - Amaldiçoados são os buscam uma vida rica antes do túmulo, pois eles perecerão no meio da abundância!

Abençoados são os destruidores da falsa esperança, pois eles são os verdadeiros Messias - Amaldiçoados são os adoradores de Deus, pois eles serão divididos pelo carneiro!

Abençoados são os valentes, pois eles obterão grande tesouro - Amaldiçoados são os crentes no bem e no mal, pois eles serão aterrorizados pelas sombras!

Abençoados são aqueles que pensam no que é melhor para si, pois suas mentes nunca serão aterrorizadas - Amaldiçoados são as "ovelhas de Deus", pois eles serão sangrados mais claro que a neve!

Abençoado é o homem que tem poucos inimigos, pois eles farão dele um herói - Amaldiçoados é o que faz o bem aos outros que o escarnecem em retorno, pois ele será desprezado!

Abençoados são os de mente poderosa, pois eles serão cavalgarão o furacão - amaldiçoados são aqueles que ensinam mentiras por verdades e verdades por mentiras, pois eles são uma abominação!

Muito amaldiçoados são os fracos cuja insegurança os tornam vis, pois eles servirão e sofrerão!

O anjo do autoilusão está acampado nas almas do honrado - A chama eterna do poder preenche de alegria interior a carne do Satanista!

Aqui não há bem-aventuranças, só maldições em forma de imprecações. Poderíamos também denominar seu Sermão de Os Bem-amaldiçoados de Satã. LaVey insulta e debocha dos cristãos e suas bem-aventuranças. O pior é contatar que talvez ele tenha razão, os fortes vencem, os fracos 
sofrem, parece que a Bíblia do chamado Príncipe das Trevas, do Papa Negro teve todas as suas profecias cumpridas! O mandamento maior do Papa Negro e da Bíblia Satânica é Morte ao fraco, saúde ao forte. Ou como diria o filósofo Quincas Borca, criação de Machado de Assis: ao vencedor as batatas...

A criatividade infinita dos textos quase anônimos que pululam na Internet é algo espantoso. Ninguém sabe de onde veio, quem começou, quem incrementou, quem acrescentou, quem corrigiu, quem editou, quem terminou, quem pôs na rede, quem divulgou. Assim surgem na internet textos quase que coletivos, sem autoria que ganham vida e acréscimo a cada vez que são consultados e lidos. O texto não é de ninguém e é de todos. É o que eu chamo de deuteronomista cibernético. Geralmente estes textos têm uma motivação para cair na rede: uma data ou acontecimento especial. Esta paródia do Sermão da Montanha apareceu no ano retrasado, por ocasião do dia do Professor. Certamente alguém, ou vários satiristas anônimos quiseram homenagear seus sofridos e injustiçados mestres. Denominei esta versão de O Sermão da Montanha na versão ao Mestre com Carinho em homenagem ao belo filme da década de sessenta intitulado Ao Mestre com carinho, com a brilhante interpretação do ator Sidney Poitier.

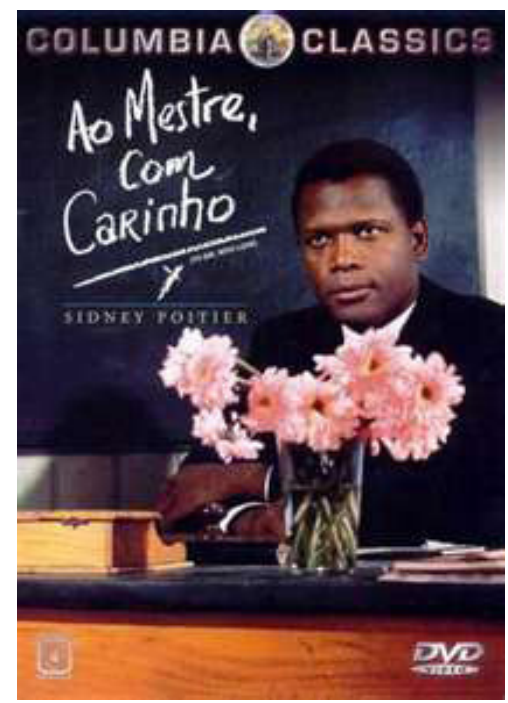

Fig. 9. Ao Mestre com carinho 
Naquele tempo, Jesus subiu a um monte seguido pela multidão e, sentado sobre uma grande pedra, deixou que os seus discípulos e seguidores se aproximassem.

Ele os preparava para serem os educadores capazes de transmitir a lição da Boa Nova a todos os homens.

Tomando a palavra, disse-lhes:

- Em verdade, em verdade vos digo:

- Felizes os pobres de espírito, porque deles é o reino dos céus.

- Felizes os que têm fome e sede de justiça, porque serão saciados.

- Felizes os misericordiosos, porque eles...?

Pedro o interrompeu:

- Mestre, vamos ter que saber isso de cor?

André perguntou:

- É pra copiar?

Filipe lamentou-se:

- Esqueci meu papiro!

Bartolomeu quis saber:

- Vai cair na prova?

João levantou a mão:

- Posso ir ao banheiro?

Judas Iscariotes resmungou:

- O que é que a gente vai ganhar com isso?

Judas Tadeu defendeu-se:

- Foi o outro Judas que perguntou!

Tomé questionou:

- Tem uma fórmula pra provar que isso tá certo?

Tiago Maior indagou:

- Vai valer nota? 
Tiago Menor reclamou:

- Não ouvi nada, com esse grandão na minha frente. Simão Zelote gritou, nervoso:

- Mas porque é que não dá logo a resposta e pronto!?

Mateus queixou-se:

- Eu não entendi nada, ninguém entendeu nada!

Um dos fariseus, que nunca tinha estado diante de uma multidão nem ensinado nada a ninguém, tomou a palavra e dirigiu-se a Jesus, dizendo:

- Isso que o senhor está fazendo é uma aula?

- Onde está o seu plano de curso e a avaliação diagnóstica?

- Quais são os objetivos gerais e específicos?

- Quais são as suas estratégias para recuperação dos conhecimentos prévios?

Caifás emendou:

- Fez uma programação que inclua os temas transversais e atividades integradoras com outras disciplinas?

- E os espaços para incluir os parâmetros curriculares gerais?

- Elaborou os conteúdos conceituais, processuais e atitudinais?

Pilatos, sentado lá no fundão, disse a Jesus:

- Quero ver as avaliações da primeira, segunda e terceira etapas e reservo-me o direito de, ao final, aumentar as notas dos seus discípulos para que se cumpram as promessas do Imperador de um ensino de qualidade.

- Nem pensar em números e estatísticas que coloquem em dúvida a eficácia do nosso projeto.

- E vê lá se não vai reprovar alguém!

E, foi nesse momento que Jesus disse: "Senhor, por que me abandonastes..." 
Ou seja, se Jesus fosse professor, coitado dele, seu ministério teria acabado nas primeiras palavras do seu magistério!

Há um livro de ficção que aborda a questão da intertextualidade de forma criativa. Trata-se do livro do escritor anglo-indiano Salman Rushdie, escrito justamente quando ele fugia do fundamentalismo islâmico do Irã que decretou contra ele uma sentença de morte (fatwa) em 1989, logo após ter escrito seu polêmico livro Versos Satânicos. O livro infantojuvenil, impressionante conto de fadas moderno, intitula-se Haroun e o Mar de Histórias, publicado em 1990. O menino Haroun era filho de um contador de estórias - Rashid. Seu pai, após ser traído por sua mãe, que havia fugido com o vizinho, perdeu a capacidade de narrar estórias. Ele ganhava a vida contando estórias. Rashid recebia, pela torneira da casa, a água das histórias, que vinha de uma segunda lua da terra que nunca fora rastreada: Kahani. Rashid perdeu a alegria de viver, cancelou o fornecimento da água das histórias. Seu filho Haroun, com a ajuda de um gênio chamado Iff, viajou até essa lua para tentar reverter o cancelamento da água das histórias. Não vamos contar toda a estória, mas o que nos interessa é a parte em que Haroun chega a lua Kahani e encontra o magnífico Mar de Fios de Histórias:

Olhou para a água e reparou que ela era feita de milhares e milhares de correntes diferentes, cada uma de uma cor diferente, que se entrelaçavam como uma tapeçaria líquida, de uma complexidade de tirar o fôlego; e Iff explicou que aqueles eram os Fios de Histórias, e que cada fio colorido representava e continha uma única narrativa. Em diferentes áreas do oceano, havia diferentes tipos de histórias, e como todas as histórias que já foram contadas e muitas das que ainda estavam sendo inventadas podiam se encontrar ali, o Mar de Fios de Histórias era, na verdade, a maior biblioteca do universo. E como as histórias ficavam guardadas ali em forma fluída, elas conservavam a capacidade de mudar, de se transformar em novas versões de si mesmas, de se unir a outras histórias, de modo que, ao contrário de uma biblioteca de livros, o Mar de Fios de Histórias era muito mais que 
um simples depósito de narrativas. Não era um lugar morto, mas cheio de vida" (RUSHDIE, 2008, s/p negrito nosso).

A pesquisadora da UFSC, Gilka Giradello, analisando o livro de Salman Rushie, afirma que:

\section{O Mar de Fios de Histórias é aí uma metáfora} para a textura narrativa da cultura. Quanto mais intrincada, colorida e diversa essa textura, mais vivo estará o mar (...). A arte narrativa aparece aí como um mecanismo inerente ao tecido da cultura.

Como há milhares de peixes, mil bocas no mar, fica claro que a tarefa recriadora pertence ao conjunto da viva tapeçaria líquida da cultura.

Há milhares de fios de histórias, há milhares de peixes no mar: a vitalidade da cultura aparece nessa imagem de Salman Rushdie como inseparavelmente ligada à biodiversidade do mar de histórias. O mar de histórias é uma imagem poética muito forte, presente há séculos na imaginação da humanidade. Essa imagem dá conta de um certo caráter "líquido" das histórias — fluido, mutável — que volta e meia é percebido pelas pessoas que pensam sobre narrativa. (2010, p. 3, negrito nosso)

E nossos escritores aqui citados: Machado de Assis, Jorge Luiz Borges, LaVey, e os anônimos da Internet fazem o papel de Peixe mil bocas, mergulham na tapeçaria líquida do grande mar de História que é a Bíblia, trituram o antigo e apresentam com uma maravilhosa roupagem, assinam as suas bem ou aventuranças, demonstrando que não há nada de novo debaixo da terra, mas que suas obras são reescrituras de obras do passado, com a assinatura do gênio. Ou como dizia Paulo Leminski em Ensaios Crípticos: "A literatura é telepatia com todo o passado, as obras são variantes de todas as obras anteriores. Não é o indivíduo que faz literatura, é a humanidade" (1986, s/p, negrito nosso.) Para Leminski, a intertextualidade é condição primordial da criação literária.

Bem-aventurados sois vós leitor que tivestes a oportunidade de conhecer todas estas paródias das Bem-Aventuranças! 


\section{Bibliografia}

ASSIS, MACHADO. A Igreja do Diabo. Disponível em: < http://www. dominiopublico.gov.br/pesquisa/DetalheObraForm.do?select_action $=\& c 0$ obra $=1903>$. Acesso em: 30 maio 2012.

O Sermão do Diabo. Disponível em: < http://pt.wikisource.org/ wiki/O_Serm\%C3\%A3o_do_Diabo>. Acesso em: 30 maio 2012.

BÍBLIA de Jerusalém. Ed. rev. e ampl. 7. reimpressão. São Paulo: Paulus, 2011.

BÍBLIA Sagrada. Trad. João F. de Almeida. Versão atualizada. Disponível em: $<$ http://www.luteranos.com.br/biblia/portugues/portugues.html>. Acesso em 4 jun. 2012.

BLOOM, Harold. A angústia da influência: uma teoria da poesia. 2. ed. Trad. Marcos Santarrita. Rio de Janeiro: Imago, 2002.

BORGES, Jorge Luis. Elogio da Sombra. In. Obras Completas. Vol. II 1952-1972. 2. reimpressão. São Paulo: Globo, 2000. Disponível em: <http:// pt.scribd.com/doc/27751535/BOR GES-Jorge-Luis-Elogia-Da-Sombra>. Acesso em: 30 maio 2012.

CHAIN, Iza Gomes da Cunha._O Diabo nos Porões das Caravelas. Juiz de Fora: EUFJF, 2003.

FINKELSTEIN, Israel; SILBERMAN, Neil Asher. A Bíblia não tinha razão. Trad. Tuca Magalhães. São Paulo: Giafa, 2003.

GIRARDELLO, Gilka. A Imaginação Infantil e as Histórias da TV. Ateliê da Aurora/NICA, artigos, 2010, p. 1-7. Disponível em: <http://www. nica.ufsc.br/wp-content/uploads/2010/01/A-imaginacao-da-infantil-eas-historias-da-tv.pdf $>$. Acesso em: 22 set. jun. 2010.

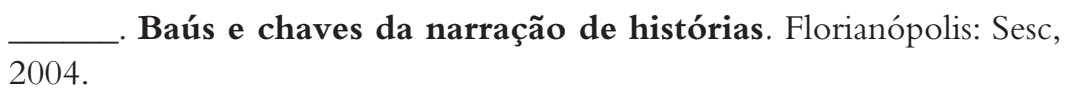
JUNQUEIRA, Guerra. Prefácio à segunda edição. A Velhice do Padre Eterno. Disponível em: < http://dc206.4shared.com/doc/erALGQtI/preview.html >. Acesso em: 27 maio 2012. 
KRISTEVA, Julia. Introdução à Semanálise. Trad. Lúcia Helena França Ferraz. São Paulo: Perspectiva, 1974.

LEMINSKI, Paulo. Ensaios Crípticos. Campinas: Unicamp, 1986.

LIBANIO, J. B. Qual o futuro do Cristianismo. 2. ed. São Paulo: Paulus, 2008.

MEIER, JOHN P. Um judeu marginal. São Paulo: Imago, 1993, Volume I.

MILES, Jack. Deus - uma Biografia. Trad. José Rubens Siqueira. São Paulo: Companhia das Letras, 1997.

MINOIS, Georges. História do Riso e do Escárnio. Trad. Maria Helena Ortiz Assumpção. São Paulo: Unesp, 2003.

RUSHDIE, Salman. Haroun e o Mar de Histórias. São Paulo: Companhia das Letras, 2008.

VIELHAUER, Philipp. História da Literatura Cristã Primitiva. Trad. Ilson Kayser. São Paulo: Academia Cristã Ltda., 2005.

\section{Imagens}

Fig. 1. A Velhice do Padre Eterno I. Disponível em: <http:// multimedia.fnac.pt/multimedia/PT/images_produits/PT/ ZoomPE/7/8/1/5601072511187.jpg?201012152021>. Acesso em: 31 maio 2012.

Fig. 2. A Velhice do Padre Eterno II. Disponível em: <http://4.bp.blogspot.com/-1vypjEtbHog/TZHgTBF14aI/AAAAAAAAAh8/v-js8TUpofl/ s1600/lealdacamara.jpg >. Acesso em: 31 maio 2012.

Fig. 3. Dez Mandamentos. Disponível em: <http://t3.gstatic.com/ images?q=tbn:ANd9GcSEAR4GE6gsFhWO8ifK8n375fWkni-TspoZdjg2M7BC5xU_-VUJcw>. Acesso em: 31 maio 2012.

Fig. 4. Sermão da Montanha. Disponível em: <http://ts4.mm.bing.net/ images $/$ thumbnail. aspx?q $=4836073618539315 \mathrm{\& id}=8 \mathrm{fe} 18 \mathrm{efce} 569 \mathrm{~d} 55502 \mathrm{f} 4 \mathrm{c}-$ 47cf1df6f05>. Acesso em: 31 maio 2012. 
Fig. 5. A Paixão de Cristo, Mel Gibson (2004). Disponível em: <http:// ts3.mm.bing.net/images/thumbnail.aspx?q=5053386075340822\&id=9159a174c08777361864dd4d4903a4bb>. Acesso em: 31 maio 2012.

Fig. 6. O Diabo. Disponível em: <http://3.bp.blogspot.com/_fFZOnbqkoAU/Ski8CzE138I/AAAAAAAAA0o/TzNd_7xEZa8/s320/images.jpg>. Acesso em: 31 maio 2012.

Fig. 7. Jorge Luis Borges e sua biblioteca. Disponível em: <http://1.bp.blogspot.com/-qkuNut56p-s/Tty2eXaiZUI/ AAAAAAAAH04/46SFxRfc23A/s1600/jorge-luis-borges.jpg >. Acesso em: 31 maio 2012.

Fig. 8. The Satanic Bible. Disponível em: <http://ts4.mm.bing. net/images $/$ thumbnail.aspx?q $=4882098478383643 \& \mathrm{id}=$ cb3dbc782d48663c8b7e9697ea67c637>. Acesso em: 31 maio 2012.

Fig. 9. Ao Mestre com carinho. Disponível em: <http://ts2.mm.bing.net/ images $/$ thumbnail.aspx?q $=4878744121903905 \& \mathrm{id}=$ f6e7f69ebed32ff214ab074abb6d9ae8>. Acesso em: 31 maio 2012. 


\title{
Primórdios do mito Faústico: o Faustbuch e o Fausto de Christopher Marlowe
}

\author{
Antonio Augusto Nery (UFPR) ${ }^{1}$
}

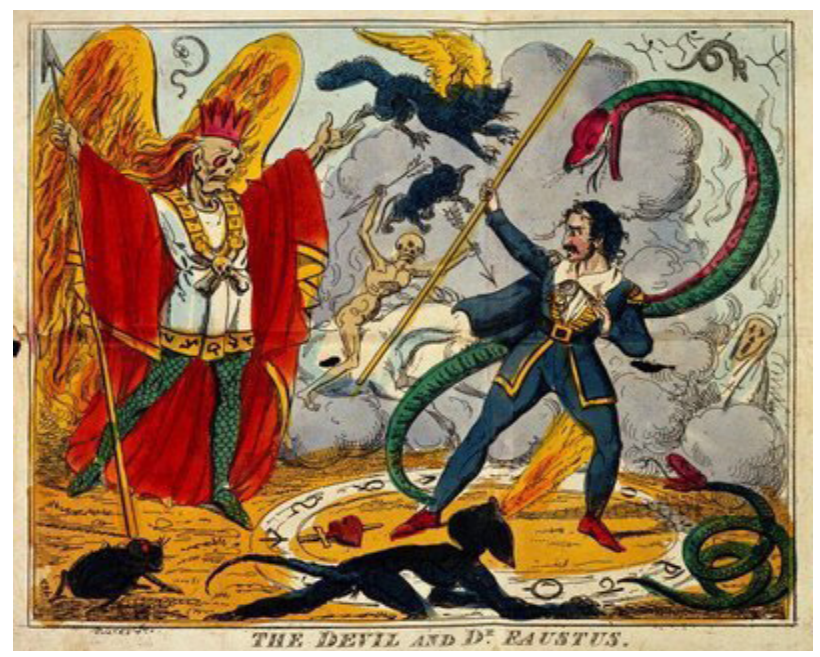

Muitas são as especulações sobre a real existência de um médico alemão que viveu no início do século XVI e que teria feito um pacto com o diabo para conseguir sabedoria plena. De acordo com Ian Watt (1997, p. 19) não se pode precisar se de fato Jorge Fausto realmente existiu, mas o crítico postula que o provável Johann Georg Faust nasceu em Knittlingen em 1480 e morreu em Staufen em 1540. Sua fama foi construída ainda em vida graças a arte da magia que teria exercido na Alemanha durante o século XVI.

1 Doutor em Letras (Literatura Portuguesa) pela Universidade de São Paulo (USP). Professor Adjunto de Literatura Portuguesa da Universidade Federal do Paraná (UFPR). E-mail: gutonery@hotmail.com. 
Obviamente que o suposto mago não era bem quisto pelas autoridades civis e religiosas, uma vez que a magia era considerada prática abominável pelo Cristianismo, contrariando principalmente a Igreja Católica que reivindicava para si a exclusividade do controle sobre o mundo sobrenatural.

Entretanto, como bem explica Ian Watt, não foi a ortodoxia católica que encampou a luta contra Fausto e sim os novos pastores protestantes, talvez pelo contexto geográfico no qual a personagem teria vivido, berço do protestantismo.

De fato, logo após o advento das teses de Lutero foi fértil a produção de uma literatura voltada a fundamentar a doutrina nascente. Entre os temas tratados por esses escritos, estava a figura do diabo:
A extraordinária floração, na Alemanha, de uma literatura especializada em 'livros do diabo', no decorrer da segunda metade do século XVI, dava testemunho da importância da figura diabólica, igualmente muito presente nos poemas e peças de teatro. A propaganda partidária dele fez igualmente grande uso para melhor diabolizar o inimigo reli- gioso, particularmente o papa, considerado como o Anticristo, anunciador do reino de Satã neste mundo. (MUCHEMBLED, 2001, p. 73).

WATT (1997) e MUCHEMBLED (2001) em suas reflexões citam vários trechos das obras de Lutero, principalmente do livro Conversações à mesa (1531-1546), nos quais o fundador do protestantismo refere-se a um certo feiticeiro Fausto que compactuava com o demônio, fato que nos faz pensar que a lenda de Fausto pode ter sido valorizada pela importância que Martinho Lutero deu à história deste seu contemporâneo. Aliás, para Watt, foram Lutero e seus seguidores os responsáveis por instituir a relação entre Fausto e o demônio, além de outras características do mito fáustico, relacionadas ao pacto com o diabo, que permaneceram para a posteridade. A história de Fausto era uma das obras que figuravam na literatura especializada do luteranismo empenhada em "explicar" o demônio² ${ }^{2}$ (Cf. WATT, 1997, p. 31).

2 Essa literatura foi muito difundida entre os anos de 1545 até 1604 e ficou conhecida 
Essas menções foram capitais para outros autores protestantes conservarem a história em suas obras de orientação e doutrina, acrescentando a ela detalhes e tendo-a como exemplificação daqueles que "se vendiam" ou faziam pactos com o diabo. Dessa forma, acabaram por instituir Fausto como exemplo do homem que pactuou com o demônio e sofreu as consequências por isso, pois, a possível morte do protagonista, operada pelo diabo, era consenso praticamente em todos os escritos desses autores (Cf. WATT, 1997, p. 30-31).

A instituição religiosa protestante não somente ajudou na difusão como também complementou a lenda que viria a ser conhecida na posteridade. De acordo com Watt, após a morte do "real" Fausto houve o aumento do interesse por sua história, justamente pelos escritores protestantes que a difundiam: "Foi essa reação negativa dos luteranos que acabou por transformar o Jorge Fausto histórico em uma figura lendária, mitológica, ao inventar seu pacto com o Demônio e seu terrível desenlace” (WATT, 1997, p. 31).

Parece-nos, portanto, que a história de Fausto passou a ser um exempla religioso, principalmente porque na Alemanha da segunda metade do século XVI, houve um empenho por parte dos protestantes em realizar uma nova prática de caça às bruxas depurada da tradição católica (Cf. NOGUEIRA, 1986, p. 73-78). Retiraram-se muitos ritos - inclusive a possibilidade dos sacramentos, o que ocasionou mais desespero por parte dos crentes, pois não se tinha nenhuma "ajuda" material para lutar contra as "forças demoníacas" -, porém a perseguição continuou vigorosa e extrema, diferenciando-se na forma, mas conservando o essencial do ritual católico: a caça aos "emissários" do diabo.

A lenda de Fausto que chegou ao conhecimento de Christopher Marlowe (1564-1593), de Goethe (1749-1832), e de vários outros autores que ajudaram a eternizar o mito fáustico, foi, provavelmente,

como Teusfelsbücher, literalmente "livros do diabo". De acordo com MUCHEMBLED (2001, p. 149): “Os Teusfelsbücher tinham sido, praticamente todos, redigidos por pastores luteranos, autores de 32 dos 39 títulos, a fim de denunciar os vícios e os pecados de seu tempo e de advertir os homens contra a prática de superstições, da magia ou da feitiçaria. Eles assumiram gêneros bem diversos: sermões, panfletos, compêndios, peças teatrais, cartas abertas, poemas didáticos, narrativas curtas... Seu valor literário era igualmente muito variável, quase sempre medíocre". 
proveniente do primeiro livro escrito sobre a vida do mago, publicado em Frankfurt no ano de 1587 por Johann Spiess. Esse livreiro e escritor de Frankfurt, que pretendeu escrever uma história verídica sobre um seu contemporâneo, é considerado aquele que permitiu a Mefistófeles tornar-se figura recorrente ao longo de cinco séculos da literatura ocidental (Cf. WATT, 1997, p. 34).

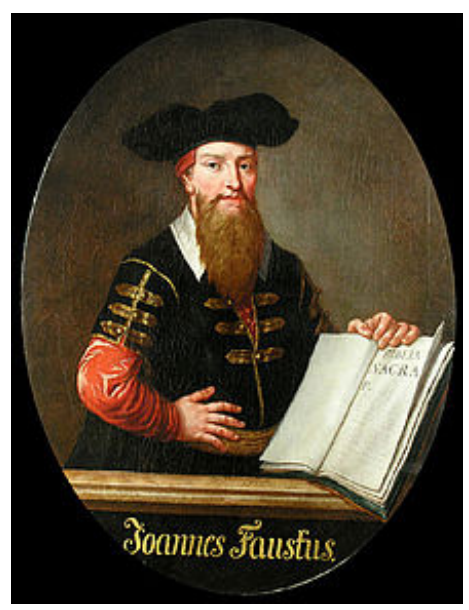

A obra era um volume de 227 páginas, intitulada Historia von dr. Johann Fausten, mas que ficou conhecida apenas como Faustbuch. Nela, a influência luterana que mencionamos acima já estava posta, mas a ideia de pacto, com detalhes sobre um contrato realizado para a morte do protagonista, só seria veiculada a partir dessa publicação ${ }^{3}$.

O texto pauta-se justamente na ideia do acordo e das desgraças que Fausto vivera por ter pactuado com o demônio, bem como nas extensas elucubrações entre Fausto e Mefistófeles que perpassam assuntos relativos à magia, teologia, astronomia e as viagens empreendidas

3 Segundo MUCHEMBLED (2001, p. 83) a ideia de pacto com o demônio constituia-se aos olhos da Instituição religiosa uma falta muito grave e repreensível, justamente pelo fato de que tal ato significava que o indivíduo estava por livre e espontânea vontade entregando-se a Satanás, diferente de outros que podiam ser ludibriados. Para o crítico essa ideia começou a ser difundida e severamente punida no contexto da Inquisição quando as feiticeiras eram acusadas de se doarem espontaneamente para o diabo. Na trama faustiana podemos conceber o pacto como um avanço, haja vista tornar-se mais um dos elementos da história que representa a liberdade de escolha individual do protagonista, sem ser cerceado por qualquer força coercitiva. 
pelo protagonista. Esses temas também estarão presentes nos diálogos das outras futuras revisitações do mito fáustico, mas as semelhanças parecem parar por aí, pois o interesse da narração do Faustbuch reside na moral retirada das cenas protagonizadas por Fausto e por Mefistófeles, em uma clara intenção proselitista, estando as duas personagens desfocadas na narração, bem ao contrário daquilo que irá acontecer já nas primeiras releituras da história, como a peça de Christopher Marlowe que logo mais analisaremos.

No Faustbuch está presente, principalmente na parte final, a preocupação do protagonista com a danação e o fim trágico que o aguarda demonstrando a angústia e a necessidade do arrependimento dos supostos erros cometidos perante Deus. Embora não se tenha detalhes da morte, fica claro que Mefistófeles cobra o acordo firmado e retém para si a alma do intrépido mágico.

A moral reiterada no desfecho é de que o futuro daqueles que desafiam Deus, os orgulhosos, os soberbos e os que possuem ambição desmedida, é o convívio eterno com Satanás e com o inferno.

A instituição religiosa, especialmente Lutero e sua Igreja nascente, aproveitou-se muito desse desfecho do Faustbuch para aplicar sua moral e exemplificar para os fiéis o imutável fim de quem se aliava com o demônio, conforme explica Ian Watt:

(...) a danação de Jorge Fausto foi dada a conhecer postumamente mediante a impressão de numerosos panfletos e livros populares; (...) o ímpeto daquela danação veio através da obsessão de Lutero em conceber a vida como um perpétuo duelo contra Satanás. Lutero indicava o Diabo para explicar cada tentação, dúvida ou episódio desagradável em sua vida pessoal. (WATT, 1997, p. 27, negrito nosso).

Se comparado à lenda, há uma grande mudança entre aquilo que era veiculado na oralidade e o que foi escrito no Faustbuch sobre a vida do Doutor Fausto. O pensamento luterano transparece ter sido, de fato, fundamental para o desenvolvimento desta primeira ficção que teve Fausto como protagonista. 
O demônio permanece aqui com a essência medieval, de perdedor das almas, servindo aos propósitos moralizantes cristãos. Seus discursos na trama são longos e substanciais, mas, na verdade, servem apenas para revelar os detalhes do acordo firmado com o sangue de Fausto, o que decretou a perdição da alma do mágico e o tornou um homem sem futuro.

A história de que após conceder benefícios, o diabo exigia em contrapartida a alma do indivíduo, já estava presente nos manuais de caça às bruxas. Esses livros traziam inclusive muitas indicações de como o processo se dava, entre elas estava o famigerado acordo firmado com o sangue da "vítima". De acordo com BRASEY (2006, p. 46):

Em troca de tais benefícios, [o diabo] mandava o novo vassalo assinar um pacto redigido em um pergaminho virgem e assinado com o próprio sangue, antes de lhe imprimir sua marca em algum lugar no corpo. Esta era facilmente reconhecível pela forma que sugeria: lebre, pata de sapo, gato preto ou cão. Indelével, só podia ser apagada pelo próprio demônio. Era justamente essa "marca do Diabo", tido por insensível, que os inquisidores se empenhavam em procurar no corpo dos supostos bruxos.

Além do mais, histórias de personagens que entregaram sua alma ao diabo, em troca de algo, eram uma constante em tempos anteriores ao período no qual viveu o suposto verdadeiro Fausto: "Desde a mais remota antiguidade e ao correr da Idade-Média não faltaram exemplos que tivessem entregado ao demo ou que lhe tivessem prometido a alma em troca de benefícios neste mundo: de poder, de riqueza, etc." (CABRAL, s.d., p. 11) ${ }^{4}$.

4 WATT (1997) ao estudar o mito fáustico, também explica que a noção de que somente a magia diabólica possibilitaria a satisfação de todos os desejos terrenos sempre esteve presente no imaginário ocidental ao longo dos séculos, quando se pensava nos poderes advindo do reino sobrenatural. Talvez tal noção foi desenvolvida a partir dos próprios Evangelhos, por intermédio das menções feitas a Satã em algumas passagens dos livros e das explicações que os evangelistas davam a elas. A menção mais significativa, sem dúvidas, é quando o diabo tenta Jesus no deserto. Satã propõe várias vantagens para Cristo, 
A cena do acordo feito com o sangue permanecerá na maioria das outras releituras sobre a vida de Fausto. O principal objetivo, sem dúvidas, é explicitar e corroborar os sentidos, os efeitos e a ligação do pacto "sanguinário" com a danação do protagonista no desfecho da trama.

Portanto, não precisamos pensar muito para entender o porquê de se ter um Mefistófeles tão eloquente, presente e companheiro do protagonista desde esta primeira versão da história de Fausto e que permanecerá com o mesmo sentido em muitas outras ficções posteriores. Watt expõe os motivos e com qual finalidade concebe-se o diabo neste período inicial de releitura do mito fáustico:

O mito do Fausto desponta no momento em que o Cristianismo, no seu desenvolvimento, pensa ter polarizado os mundos do humano e do sobrenatural em conflito entre o mal e o bem, conferindo à luta dentre as duas partes uma nova intensidade e um novo vigor. Isso inevitavelmente proporcionou ao Diabo e a sua hierarquia uma importância teológica e psicológica sem precedentes. (WATT, 1997, p. 27).

De acordo com Ian Watt: "O moralismo vulgar e complacente do autor do Faustbuch reflete os aspectos da caça ao diabo empreendida pelos luteranos na Alemanha, sem contudo passar do superficial" (WATT, 1997, p. 40). Essa superficialidade a que se refere Watt pode ser o fato de que Faustbuch não conseguiu refletir com profundidade os aspectos da "caça ao diabo e a seus emissários" realizada pelos protestantes, pois, conforme explicita o crítico, a intensidade das perseguições não diferenciava-se muito da "caça às bruxas" empreendida pelos católicos: "luteranos, calvinistas e católicos romanos foram igualmente ativos na caça às feiticeiras” (Cf. WATT, 1997, p. 29).

caso ele se abstenha dos projetos e desígnios de Deus. Entre as ofertas estão o poder sobre todo o mundo, a detenção de grande riqueza material e a supressão da fome, em suma, o ter, o poder e o ser. Jesus em nenhum momento desclassifica, contesta, ou desautoriza o poder de Satanás em conceber tais proezas, apenas ordena, de forma vaga, que o demônio evada-se: "Para trás, Satanás, pois está escrito: Adorarás o Senhor teu Deus e só a ele servirás” (Cf. MT 4, 11; LC 4,12; MC 1, 12s). 
Mesmo sendo perceptível o comprometimento do Faustbuch com as descrições do diabo medieval, bem como com o moralismo cristão protestante, tendo fins proselitistas e doutrinários, não podemos deixar de notar, todavia, que há certo avanço no desenvolvimento da personagem do diabo em comparação com outros textos que figuravam neste período em toda a Europa, como os diversos livros doutrinais e teológicos de "caça às bruxas".

Há na obra uma considerável atenção dada à personagem de Mefistófeles, ele tem direito à fala, com longos discursos e, mesmo que esses sirvam a interesses moralistas, através do diálogo com Fausto podese perceber a proximidade de Mefistófeles com os lamentos humanos, bem como a expressão de elementos individualistas que é marca registrada de Fausto, principalmente nas releituras vindouras sobre o mito.

Talvez seja esta pequena inovação difundida pelo Faustbuch que seduzirá outros escritores e os farão reler Fausto e Mefistófeles, incrementando não somente a figura do protagonista, mas, também, a do "anjo negro".

Partamos para a averiguação de uma das primeiras obras a fazer uma releitura do mito fáustico, a peça teatral The Tragical History of the Life and Death of Doctor Faustus, escrita provavelmente em 1592, pelo inglês Christopher Marlowe.

Aproveitando-se da tradução inglesa do Faustbuch ${ }^{5}$, Marlowe desenvolveu sua ficção de forma inovadora. Conforme WATT (1997, p. 42), foi ele quem estabeleceu o mito, e permitiu que permanecesse vivo na literatura e no teatro, para que, assim, dois séculos depois, Goethe desenvolvesse sua obra clássica que caracterizou, fundamentou e eternizou o mito literário que chegou a contemporaneidade.

Marlowe desenvolve sua história em plena efervescência intelectual, incentivado pela atmosfera criativa do teatro elisabetano. A ficção, com muitos contornos trágicos, expressa de forma concisa a excitação pelo conhecimento, o entusiasmo pela beleza terrena e a concepção de danação espiritual que vigorava no período renascentista.

5 Conforme CABRAL (s.d., p. 12) o Faustbuch foi traduzido para o inglês em 1592 por um anônimo que se identificou apenas com as iniciais P.F. e até nossos dias não há informações sobre sua identidade. 
Para WATT (1997, p. 44): “as maiores contribuições de Marlowe à substância do mito do Fausto podem ser resumidas em três tópicos: escolha da vocação individual; alienação acadêmica; e danação eterna". Segundo o crítico é a partir desta ficção que se tem um Fausto dedicado ao conhecimento para além do universo restrito de uma só área, com várias opções de escolhas de acordo com os desejos da vontade individual.

Nas falas iniciais do protagonista nota-se o drama vivenciado pelo pensamento individualista nascente, pois, lado a lado, estão as diversas expectativas quanto às possibilidades profissionais e as desilusões relativas aos diversos impedimentos de se exercer a profissão depois de formado, ou seja, questionamentos sobre o fato de se ter várias possibilidades de formação, sem a garantia de um futuro promissor. A saída para Fausto nesse imbróglio reside na busca pela magia:

Fausto: Só me rumina a mente em nigromancia,

Pra mim, Filosofia é escura, odiosa,

Direito e Medicina são mesquinhos,

De todas a mais baixa é Teologia,

Desagradável, rude, ignara e vil.

Só a magia, a magia me encanta! (MARLOWE, s.d., p. 32).

Muito próximo disso está o desejo de abarcar todo o conhecimento do mundo e dos mistérios sobrenaturais, fatos que contradiziam as orientações das instituições religiosas, tanto católica quanto protestante. Nos discursos do protagonista fica clara a afronta ao universo restrito proposto pelas Instituições da época e patente que tal concepção precisava ser superada. Há na história uma valorização de particularidades individuais e não morais do indivíduo, além da aventura de transpor as possibilidades propostas pelo contexto ao qual se estava inserido.

Trata-se, portanto, do início da divinização do homem e da relativização de Deus, ao menos daquele Deus descrito pelas Igrejas da época. Processo esse que será muito difundido nas produções dos escritores do século XVI, período dividido entre a religiosidade medieval e o humanismo renascentista. Parece-nos, portanto, que da obra de Marlowe ecoou para a posteridade a visão universalista do conhecimento, a exaltação do 
ego individual e a importância dada às escolhas particulares voltadas ao futuro que se apresenta para cada indivíduo. Consoante Watt:

A idéia medieval de que cabia à religião e à moral conter o indivíduo no seu lugar hierárquico, aquele que lhe foi reservado pela sociedade, era frontalmente contrária à ideologia da moderna sociedade individualista, com seu pressuposto de que cada indivíduo deveria ter igual oportunidade. (WATT, 1997, p. 48).

Por todas essas particularidades, Ian Watt (1997, p. 52) defende que o Fausto de Marlowe pode "ser visto como a imagem fundadora de um dos pressupostos básicos, ainda que irreal, do individualismo secular moderno", ao que complementa "[...] podemos concluir com boa dose de razão que a principal contribuição de Marlowe ao mito do Fausto foi ter dado uma nova dimensão e uma nova intensidade aos conflitos básicos do individualismo emergente" (WATT, 1997, p. 56).

Marlowe estava limitado, obviamente, pelo contexto no qual escreveu, não podendo aprofundar sua causa: "Marlowe alinhou-se no Doctor Faustus com a ortodoxia religiosa" (WATT, 1997, p. 38). Percebemos isso sobremaneira no final da obra quando se nota, nos dizeres de Fausto, certo arrependimento e remorso por ter pactuado com Satanás e obtido todos os favores que solicitou:

Fausto: Ó Deus,

Se não quiser's salvar a minha alma,

Por Cristo, cujo sangue me remiu,

Põe algum fim ao meu penar eterno!

Mil anos no Inferno viva Fausto,

Cem mil, mas...finalmente... seja salvo!

Oh! P’rás almas condenadas não há têrmo!

Fausto morreu. Que o seu caso infernal, E desgraça, ó pudentes, vos exortem

A ficar pela mera admiração

Perante o proibido, cujo abismo

Aos audazes como êle, incita a mente

A fazer mais, que o jus do Céu consente (MARLOWE, s.d., p. 129-130). 
A morte, preço pago pelo Fausto de Marlowe por querer desenvolver seus anseios individuais, será uma constante que poderíamos atribuir ao pensamento cristão advindo desde a primeira ilustração oficial da vida do mágico no Faustbuch. É a mensagem clara dada pelas instituições religiosas do que poderia ocorrer com aqueles que tentassem sair do coletivismo e da autoridade dos poderosos. A lição moral está nítida nesses trechos finais do drama. A semelhança da obra do escritor inglês com o Faustbuch, relacionadas às pretensões moralizantes e de exemplo para os cristãos, são evidentes.

Todavia, em muitos outros aspectos, há evoluções na retomada da história de Fausto feita por Marlowe, e a figuração de Mefistófeles é uma delas.

Watt propõe que o processo do pensamento individualista iniciou-se no Renascimento: "[..] em decorrência do Renascimento e da Reforma, a primazia do indivíduo sobre o coletivo tornou-se característica definidora da moderna sociedade ocidental em seu conjunto" (WATT, 1997, p. 236). A apologia era feita à livre escolha, à valorização da vida privada, ao auto -aperfeiçoamento, seja de ordem intelectual ou física. Era a possibilidade de se dizer aquilo que se pensava, mesmo que o discurso possuísse caráter obsceno, de galhofa ou de crítica social ferina. Embora essas características já estivessem presentes na literatura medieval - pensemos nas cantigas de escárnio e maldizer, por exemplo - foi, de fato, no Renascimento que a crítica apontou para questões relacionadas ao individualismo.

Parece-nos que Mefistófeles no Doctor Faustus assume uma nova faceta a partir dessas mudanças que se desenvolviam. Embora limitado pelo contexto histórico e o imaginário relativo ao demônio que ainda vigorava, Marlowe apresenta diferenças consideráveis na composição da figura demoníaca, diferenciando-se das representações medievais, principalmente dos manuais de caça às bruxas. Em parte, esse "novo" diabo, impulsionado pelo "novo homem" que surgia, é redesenhado pelo protagonista, Fausto. Na primeira cena na qual Mefistófeles aparece, Fausto exige que ele se apresente com outro aspecto, ironicamente, como um "velho franciscano piedoso", alguém provavelmente apreciável na época do ponto de vista religioso:

Fausto: Ordeno-te que vás mudar de forma, Que horrendo estás demais p'ra me servir.

Volta tal qual um velho franciscano:

Convém piedoso aspecto a um diabo...

(MARLOWE, s.d., p. 40). 
Nota-se certa intimidade de Fausto com o demônio nos longos diálogos entre os dois. Além dessa inovação para o contexto histórico, da proximidade de um humano com um representante das Trevas, todas as exigências de Fausto feitas à Mefistófeles podem ser tidas como heresias graves, pois demonstram incompatibilidades com os preceitos da Instituição religiosa.

Mefistófeles está em cena para ser exclusivamente o intermediário entre os desejos de Fausto e a concretização efetiva deles, constituindose peça fundamental no desempenho do protagonista. O fato da obra ser difundida em um período no qual apologias eram feitas a um pensamento individualista nascente, possivelmente fez com que a permanência da crítica impingida pela Instituição religiosa à história de Fausto - a de que por desejar o conhecimento ilimitado ele havia pactuado com o demônio -, se transformasse na perspectiva de que Satanás era "amigo íntimo" de todos os homens que manifestavam o desejo de desenvolver seu intelecto e o livre pensamento.

Satanás já começa a transparecer aqui também certa humanidade que seria apreciada e desenvolvida pelos escritores que revisitariam a história de Fausto futuramente. Observemos um dos trechos de seus discursos no qual temos a expressão de uma fraqueza humana, a angústia, por ele ser um anjo decaído que perdeu o céu e a oportunidade de desfrutar do Supremo Bem:

Mefist: Isto é o inferno, e fóra dêle não estou!

Pois pensas que eu, que vi de Deus a face,

E os eternos prazer's do Céu provei,

Não me atormento com dez mil infernos,

Por'star provado do perene bem?

Oh, deixa, Fausto, essas perguntas frívolas,

Que terror causam à minha alma ansiosa...

Fausto: Quê? Tão sentido o grande Mefistófeles,

Por dos prazer's do Céu privado estar? (MARLOWE, s.d., p. 44).

Embora as falas de Mefistófeles tenham tonalidades proselitistas angústia e tormenta por estar privado das benesses do Supremo Bem - suas palavras presentes no texto do dramaturgo inglês também fazem 
menção às dúvidas acerca da danação eterna. Tanto os reformistas quanto os católicos haviam consolidado a doutrina da danação para os maus e do paraíso celeste para os bons; de um lado os anjos e a virtude e de outro o demônio e o vício, isso tudo como um poderoso sistema de coerção para efetivarem a moral, a ordem social e a crença.

$\mathrm{Na}$ obra de Marlowe, temos um Fausto envolto nesse dilema. Mesmo que levemos em conta trechos como o citado acima, no qual percebemos Mefistófeles ressentindo-se da queda do Paraíso e envolto pela sensação de perda, ao contrário de Fausto que o ridiculariza, temos, em alguns episódios iniciais, Fausto imerso em questionamentos voltados a si mesmo, se segue em frente ou não com o pacto diabólico:

Fausto: Fausto, hás-de agora

Ser condenado, e salvo se não podes.

No céu e em Deus, p'ra que pensar então?

Fóra com tais loucuras, desespera,

Desespera de Deus, crê no diabo,

Sê resoluto, Fausto, não recues.

Porque vacilas? Diz-me algo ao ouvido:

- Deixa a magia, volta para Deus!

Ai, para Deus bem quer' Fausto voltar...

P'ra Deus? - Ele não te ama....

É teu próprio apetite que serves,

E dêl'te vem o amor por Belzebú...

Um altar e uma igreja lhe hei-de erguer,

Doar-lhe o sangue de recém-nascidos! (MARLOWE, s.d., p. 53-54).

Entretanto, mesmo constatando angústia e ambiguidade no decorrer da história, percebemos um Fausto que se sobrepõe às indecisões e questionamentos maniqueístas, representando os homens insatisfeitos que preferiram aquilo considerado "execrável" pelas autoridades a ser submetido a elas. No trecho acima temos na frase "Ai, para Deus bem quer' Fausto voltar.../ P'ra Deus? - Ele não te ama..." o resumo deste sentimento é o ponto novo que a peça de Marlowe inaugura na trajetória das várias versões da história de Fausto, qual seja o questionamento de que Deus não ama o homem porque não o deixa ser livre enquanto indivíduo que possui suas próprias vontades e desejos. 
Assim, temos um ser humano que preferiu gozar plenamente seus instintos e desejos terrenos, e ir para o inferno, a esperar uma suposta alegria eterna no Paraíso.

Fausto: Tivesse eu tantas almas, como há estrêlas, Tôdas por Mefistófeles as daria

Por êle serei Imperador do mundo,

Uma ponte farei nos ares moventes

P'ra o oceano passar co'um bando de homens (MARLOWE, s.d., p. 46).

A grande mensagem que paira no final é que ao contrário de ser levado aos infernos como no Faustbuch, embora com certa hesitação, Fausto optou por ele. A livre escolha ficou posta e valorizada. A peça de Marlowe finda com esta mensagem. Mefistófeles permanece como aquele que ajuda o protagonista a realizar seus desejos e anseios contrários à ordem social vigente. 


\section{Bibliografia}

BÍBLIA SAGRADA - Tradução do Centro Bíblico Católico. São Paulo, Ave Maria, 1994.

BRASEY, Édouard. Como se vendia a alma ao diabo. In: Revista História Viva - Grandes Temas, ed. 12. São Paulo, Duetto Editorial, 2006, p. 41-47.

CABRAL, A. de Oliveira. Prefácio. In: MARLOWE, Christopher. O "Fausto". Trad. de A. de Oliveira Cabral. Lisboa: Papelaria Fernandes Livraria, s.d.

MARLOWE, Christopher. O "Fausto". Trad. de A. de Oliveira Cabral. Lisboa: Papelaria Fernandes Livraria, s.d.

MUCHEMBLED, Robert. Uma história do Diabo: séculos XII-XX. Rio de Janeiro, Editora Bom Texto, 2001.

NOGUEIRA, Carlos Roberto F. O diabo no imaginário cristão. São Paulo, Editora Ática, 1986.

WATT, Ian. Mitos do individualismo moderno - Fausto, Dom Quixote. Dom Juan, Robinson Crusoé. Rio de Janeiro, Jorge Zahar Editor, 1997.

\section{Imagens:}

The Devil and Dr. Faustus. Disponível em http://marloweobra.files.wordpress.com/2009/01/faustus1.jpg, 07/10/2012

Joanes Faustus. Disponível em http://upload.wikimedia.org/wikipedia/ commons/thumb/5/58/Idealportr\%C3\%A4t_Joannes_Faustus.jpg/220px-Idealportr\%C3\%A4t_Joannes_Faustus.jpg,07/10/2012 



\section{O diabo enquanto personagem literário em $O$ bom diabo de Monteiro Lobato e Belzebu.com, de Luis Fernando Veríssimo}

Filipe Marchioro Pfützenreuter ${ }^{1}$ (UFSC/UNIBAVE)

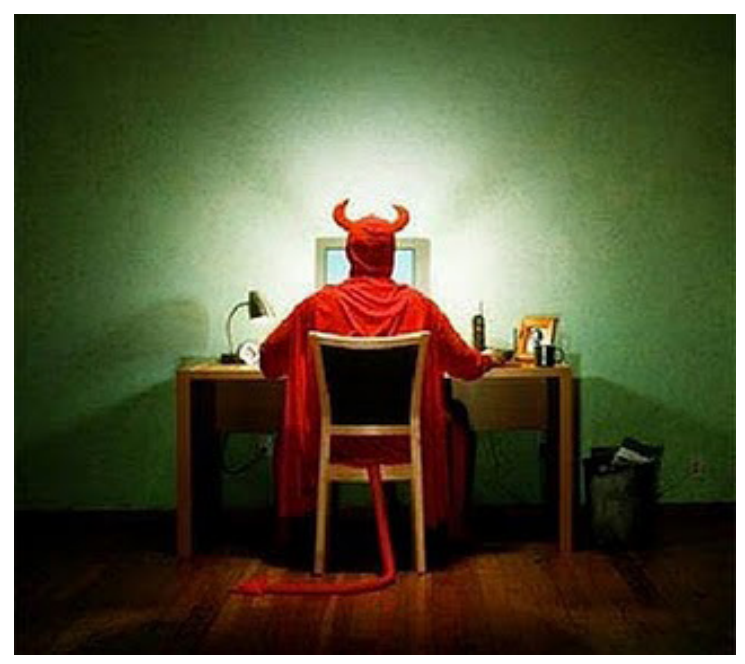

\section{Da tradição à ficção}

No discurso cristão, o Diabo aparece como a origem de todo o mal. Apartir de uma leitura do livro de Gênesis, ele se apresenta para Eva em forma de serpente e a induz a cometer o primeiro pecado da humanidade

1 Licenciado em Letras (Português/Inglês) pela Universidade do Extremo Sul Catarinense (UNESC). Mestre e Doutorando em Literatura pela Universidade Federal de Santa Catarina (UFSC). Professor do Centro Universitário Barriga Verde (UNIBAVE). E-mail: lipet0@yahoo.com.br. 
ao comer o fruto proibido. A serpente genesíaca, contudo, é apenas um dos personagens que compõem o Diabo no imaginário cristão. Além dela, é possível discernir pelo menos outros quatro: o bode expiatório, em Levítico; Satanás, no Livro de Jó; o Diabo, nos Evangelhos; e o Anjo Caído e seus heterônimos, no Apocalipse.

Segundo o livro de Gênesis, Deus criou o céu e a terra. Assim, todos os seres, as plantas, a luz, a escuridão, a água, enfim, tudo o que faz parte do mundo trata-se de uma criação divina. Esse processo todo levou seis dias. Até que no sétimo, tendo tudo concluído, Deus finalmente descansou.

A terra se transformou em um paraíso, conhecido como Éden, que abrigou os primeiros homens criados por Deus, ou melhor, o primeiro homem (Adão) e a primeira mulher (Eva) respectivamente. Dada a criação destes, não demorou muito para que o mal também tivesse origem. Tal acontecimento se deu a partir de uma árvore plantada no meio do jardim do Éden, a árvore do conhecimento do bem e do mal. Em relação a ela, Deus advertiu Adão: “De toda árvore do jardim comerás livremente, mas da árvore do conhecimento do bem e do mal não comerás; porque, no dia em que dela comeres, certamente morrerás." (Gn 2, 16-17).

Eis que surge a serpente para tentar Eva a desobedecer às ordens divinas. Com uma linguagem extremamente persuasiva, o animal convence a primeira mulher a comer o fruto proibido e, consequentemente, a cometer o primeiro pecado da humanidade:

A serpente era o mais astuto de todos os animais do campo que Javé Deus havia feito. Ela disse para a mulher: "É verdade que Deus disse que vocês não devem comer de nenhuma árvore do jardim?” A mulher respondeu para a serpente: "Nós podemos comer do fruto das árvores do jardim. Mas do fruto da árvore que está no meio do jardim, Deus disse: 'Vocês não comerão dele, nem o tocarão, do contrário vocês vão morrer'." Então a serpente disse para a mulher: "De modo nenhum vocês morrerão. Mas Deus sabe que, no dia em que vocês comerem o fruto, os olhos de vocês vão se abrir, e vocês se tornarão como deuses, conhecedores do bem e do mal". Então a mulher viu que a árvore tentava 
o apetite, era uma delícia para os olhos e desejável para adquirir discernimento. Pegou o fruto e o comeu; depois o deu também ao marido que estava com ela, e também ele comeu. Então abriram-se os olhos dos dois, e eles perceberam que estavam nus. Entrelaçaram folhas de figueira e fizeram tangas. (Gn 3,1-7)

Após o pecado original, homem e mulher recebem os primeiros castigos impostos por Deus. Ela passa a sofrer com as dores do parto e se torna submissa ao marido, enquanto ele é condenado a uma vida sofrida, trabalhando arduamente e sendo acometido por uma fome insaciável. Não obstante, o gênero humano é expulso do paraíso, tendo que, a partir de então, lutar para se redimir do pecado e reconquistar a paz. Enfim, é concebido o mundo dos homens e todas as mazelas nele existentes.

Na leitura cristã da história da criação do mundo, a serpente é o próprio Diabo e este é a origem de todo o mal. Esse raciocínio é amparado pala perspectiva de que Deus é uma entidade essencialmente benevolente e que os homens foram criados à sua imagem e semelhança: "Façamos o homem à nossa imagem e semelhança." (Gn 1, 26) Sendo assim, as criaturas não poderiam ser diferentes de seu criador, não sendo pela existência de uma força contrária, ou seja, pelo Diabo. Nessa perspectiva, Adão e Eva não teriam se interessado pelo fruto proibido se não tivessem sido tentados pela serpente.

Em Levítico, capítulo XVI, surge o segundo personagem que compõe o Diabo no imaginário cristão, trata-se do bode expiatório. No livro, Arão, que havia perdido seus dois filhos, foi incumbido de apresentar ao senhor um bode sobre o qual seriam lançados todos os pecados e impurezas dos israelitas. Em seguida, esse bode deveria ser apartado do rebanho e solto no deserto, de modo a possibilitar a purificação completa do povo.

Arão porá ambas as mãos sobre a cabeça do bode vivo e sobre ele confessará todas as iniquidades dos filhos de Israel, todas as suas transgressões e todos os seus pecados; e os porá sobre a cabeça do bode e enviá-lo-á ao deserto, pela mão de um homem à disposição para isso. (Lv 16, 21) 
Segundo Ferraz (2010, p. 18), há os que enxergam o bode expiatório como Cristo, pelo fato de ele carregar a culpa dos homens e ser morto no deserto, e há também aqueles que o enxergam como o Diabo, uma vez que fez os primeiros pais falharem, o primeiro Adão pecar. Embora a primeira leitura seja pertinente, é fato que os cristãos costumam usar a imagem do bode para representar o Diabo. Em sua imagem mais tradicional, ele se apresenta com corpo semelhante ao de um homem, mas dotado de barbicha e patas de bode. Sendo assim, não há como negar a influência do bode expiatório na composição do inimigo cristão.

O Livro de Jó, por sua vez, apresenta a história de um homem extremamente íntegro, um verdadeiro servo de Deus, mas que, a certa altura, é posto à prova pelo próprio Todo Poderoso. O fato acontece quando Deus elogia seu servo para Satanás e este argumenta que Jó precisaria ser privado de toda a sua riqueza para dar prova real de sua lealdade:

Perguntou ainda o Senhor a Satanás: Observaste o meu servo Jó? Porque ninguém há na terra semelhante a ele, homem íntegro e reto, temente a Deus e que se desvia do mal.

(...)

Estende, porém, a mão, e toca-lhe em tudo quanto tem, e verás se não blasfema contra ti e na tua face. (Jó 1, 8-11)

Ao longo da história, Jó perde seus filhos, sua fazenda e adoece. Em suma, é submetido a uma vida miserável. Entretanto, ele tem tudo restituído ao final, porque permanece fiel a Deus mesmo diante de todas as adversidades. Assim, ele recompõe sua fazenda, torna a enriquecer e tem outros sete filhos e três filhas.

Embora Satanás tenha contado com a autorização e cumplicidade divina para tentar Jó, para os cristãos, ele é o único responsável por todas as desgraças que assolam o rico fazendeiro. Mediante essa leitura, Satanás e o Diabo são compreendidos como a mesma pessoa, cujo objetivo é desvirtuar os homens de boa índole, intuindo privá-los da salvação no post-mortem.

O personagem designado pelo nome Diabo, contudo, vai aparecer pela primeira vez somente nos Evangelhos. O fato se dá quando Jesus, 
após ter sido batizado por João Batista, recolhe-se no deserto para jejuar por quarenta dias e quarenta noites, em preparação para o início da sua atividade messiânica. É nesse momento que o Diabo surge para instigá -lo a romper com seu pai e, consequentemente, para fazê-lo desistir de morrer em prol da redenção da humanidade:

Então o diabo disse a Jesus: "Se tu és Filho de Deus, manda que essa pedra se torne pão." Jesus respondeu: "A Escritura diz: 'Não só de pão vive o homem'." O diabo levou Jesus para o alto. Mostrou-lhe por um instante todos os reinos do mundo. E lhe disse: "Eu te darei todo o poder e riqueza desses reinos, porque tudo isso foi entregue a mim, e posso dá-lo a quem eu quiser. Portanto, se te ajoelhares diante de mim, tudo isso será teu." Jesus respondeu: "A Escritura diz: "Você adorará o Senhor seu Deus, e somente a ele servirá'." Depois o diabo levou Jesus a Jerusalém, colocou-o na parte mais alta do Templo. E lhe disse: "Se tu és Filho de Deus, jogate daqui para baixo. Porque a Escritura diz: 'Deus ordenará aos seus anjos a teu respeito, que te guardem com cuidado'. E mais ainda: Eles te levarão nas mãos, para que não tropeces em nenhuma pedra'." Mas Jesus respondeu: "A Escritura diz: 'Não tente o Senhor seu Deus'." Tendo esgotado todas as formas de tentação, o diabo se afastou de Jesus, para voltar no tempo oportuno. (Lc 4, 3-13)

Conforme pode se observar no texto do evangelista Lucas, assim como a serpente em Gênesis e Satanás no Livro de Jó, o Diabo do Novo Testamento aparece como um grande tentador. Nem mesmo Cristo, o filho de Deus, está salvo de suas investidas. Data a semelhança, não haveria como deixar de associar os personagens desses três livros distintos.

O Apocalipse, por sua vez, é o livro responsável por justificar definitivamente a conexão estabelecida pelos cristãos entre os personagens de Gênesis, Levítico, Jó e dos Evangelhos. É no último livro bíblico que o leitor finalmente tem acesso à biografia completa do Diabo. Este foi originalmente um anjo do Senhor, mas que foi expulso dos Céus 
após liderar uma rebelião contra ele, daí a origem da designação Anjo Caído.

Aconteceu então uma batalha no céu: Miguel e seus Anjos guerrearam contra o Dragão. O Dragão batalhou juntamente com os seus Anjos, mas foi derrotado, e no céu não ouve mais lugar para eles. Esse grande Dragão é a antiga Serpente, é o chamado Diabo ou Satanás. É aquele que seduz todos os habitantes da terra. O Dragão foi expulso para a terra, e os Anjos do Dragão foram expulsos com ele. (Ap 12, 7-9)

Como pode se observar acima, São João coloca de forma bem explícita para o leitor que o Dragão, a Serpente, Satanás e o Diabo são manifestações de uma mesma entidade. Além disso, o Diabo é claramente apontado como o responsável por todo o mal. Em uma linguagem metafórica, o texto coloca o Diabo como o responsável pelo castigo de Eva (as dores do parto), acusa-o de tentar promover a morte do menino Jesus, atribui a ele a culpa pelos pecados dos homens e, por conseguinte, pelas mazelas mundanas:

Apareceu no céu um grande sinal: uma Mulher vestida com o sol, tendo a lua debaixo dos pés, e sobre a cabeça uma coroa de doze estrelas. Estava grávida e gritava, entre as dores do parto, atormentada para dar à luz. Apareceu, então, outro sinal no céu: um grande Dragão, cor de fogo. Tinha sete cabeças e dez chifres. Sobre as cabeças sete diademas. Com a cauda ele varria para a terra parte das estrelas do céu, jogando-as sobre a terra. O Dragão colocou-se diante da Mulher que estava para dar à luz, pronto para the devorar o Filho, logo que ele nascesse. Nasceu o Filho da Mulher. Era menino homem. Nasceu para governar todas as nações com cetro de ferro. Mas o filho foi levado para junto de Deus e de seu trono. (Ap 12, 1-5)

Ainda em relação ao Apocalipse, vale pontuar que neste livro também se encontra uma descrição física do Diabo bem detalhada, pelo menos em relação a uma das suas formas: sete cabeças, dez chifres, diademas sobre 
as cabeças e calda. A partir dessas características, o imaginário popular e a arte deram origem a muitas outras imagens para ele, sendo que a mais recorrente é, sem dúvida, a de um ser horrendo, de pele vermelha ou escura, com chifres, rabo em forma de seta, barbicha e patas de bode, cheirando a enxofre e armado com um tridente.

A leitura da Bíblia enquanto obra literária tem sido cada vez mais frequente em tempos modernos. A liberdade religiosa alavancada pelo Iluminismo tirou da igreja o monopólio sobre o livro, ou melhor, sobre a compilação de livros mais vendida do mundo, fazendo com que ela deixasse de servir exclusivamente ao panfletismo religioso.

Não é por se tratar de literatura, ou também de literatura, que a Bíblia se torna menos fascinante. O que se observa é que ela não é menos fonte de provisões literárias do que é de provisões religiosas, tanto que Sabino (1995, p. 15) afirma que, somente no século XIX, foram publicados mais de sessenta mil livros a respeito de Jesus Cristo, o protagonista do Novo Testamento. Com relação ao Cristo literário, Küng assume o seguinte posicionamento:

Um escritor certamente não almeja delinear uma imagem impessoal, histórica e objetiva para Jesus, contendo todos os pormenores relevantes. O que ele procura é trazer à tona e enfatizar um aspecto que pense ser importante, para reunir um número de temas, para clarear um ponto específico. O estilo é atingido pela ênfase subjetiva. $\mathrm{O}$ escritor, como tal, não está interessado em investigação historicamente exata, mas na visão das muitas imagens existentes de Cristo, não apenas na dos concílios, mas na dos devotos e apaixonados, dos teólogos e pintores, e também dos escritores. É o teólogo que deve responder à questão: que retrato de Cristo é verdadeiro? A qual dos retratos existentes devemos nos agarrar na prática? (KÜNG, 1976, p. 143, tradução nossa $)^{2}$

2 A writer certainly does not want to draw an objective, historically accurate picture of Jesus, containing all the relevant details. What he seeks is to bring out and emphasize one aspect which he thinks important, to bring together a number of themes, to throw a clearer light on one point. Style is achieved by subject emphasis. The writer as such is not 
A afirmação de Küng em relação ao Cristo literário também vale para os demais personagens bíblicos. Da mesma forma que o escritor não objetiva resgatar o Cristo histórico, ele também não objetiva recriar um diabo teologicamente correto. O que deseja com tais personagens é inseri-los segundo os interesses de sua obra, e não distorcer sua obra de modo a adequá-la aos personagens herdados do outro contexto.

Segundo Ferraz (2007, p. 235), o Diabo está presente no mundo medieval, ocidental e também no mundo das crianças, mostrando-se excelente motivo e tema da boa literatura. Ainda segundo a autora, ele representa o maior fantasma coletivo do Ocidente e, sem ele, a literatura, a teologia e a própria humanidade não seriam as mesmas. Contudo, na Literatura Pós-Iluminista, nem sempre coube ao Diabo o papel de vilão ou antagonista, pelo menos não como se prega ao longo dos séculos no meio cristão. Conforme afirma Souza (2007, p. 8), "no século XIX, a história divina contada nos textos bíblicos começa a receber interpretações heterodoxas pela História, Filosofia e Literatura."

A presença constante do Diabo na Literatura Pós-Iluminista, seja assumindo o papel de herói em um extremo, seja assumindo o papel de vilão em outro, deu margem a uma seara de estudos literários buscando compreender o fenômeno. Em relação a O Evangelho Segundo Jesus Cristo, de José Saramago, por exemplo, Pinheiro (2007, p. 8) lembra que ele "já foi dissecado pela crítica de todo o mundo e questionado até mesmo pelo governo e pela Igreja." No entanto, esses estudos preocuparam-se mormente com as obras literárias acessadas pelo público adulto, olvidando-se daquelas que são lidas por crianças e jovens.

Vale destacar que, no presente artigo, utilizar-se-á o termo Literatura Infanto-Juvenil com o único intuído de designar um grupo de obras que é direcionado ou lido mais especificamente pelo público dessa faixa etária. O uso desse termo não implica, de forma nenhuma, em segregação operada por critérios qualitativos. Nesse sentido, assume-se a concepção de Ferraz (2007, p. 222), a qual não concorda com nenhum tipo

interested in historically exact investigation. But in view of the many Christ images not only of the councils, of the devout and the enthusiasts, of theologians and painters, and also of the writers, it is the theologian who must answer the question: which portrait of Christ is the true one? To which of them should we cling in practice? (KÜNG, 1976, p. 143) 
de divisão terminológica para a Literatura. Para a autora, esta arte deve interessar ao leitor em geral, seja ele criança, adulto, mulher, branco ou negro. Do contrário, não se trata de Literatura.

Dadas as considerações acima, o presente artigo traz na sequência uma análise do processo de composição do personagem Diabo em duas obras da Literatura Infanto-Juvenil brasileira, atentando para os contrastes e semelhanças entre o arquétipo cristão e o modo como ele ressurge nos escritos de Monteiro Lobato e Luis Fernando Veríssimo.

\section{O Diabo segundo Monteiro Lobato}

José Bento Monteiro Lobato é possivelmente um dos maiores representas da Literatura para crianças no Brasil. O paulista de Taubaté, nascido em 1882 e falecido em 1948, deixou um legado de obras que, até hoje, são lidas por crianças de todo o país e também do exterior. Dentre elas, destacam-se principalmente as que integram a coleção Sítio do Picapau Amarelo, como Reinações de Narizinho (1931), Memórias de Emília (1936) e Histórias de Tia Nastácia (1937). Nesta está incluído o conto O Bom Diabo, que reflete nitidamente a personalidade anticonvencional do artista.

O Bom Diabo narra a história de um príncipe que estava fadado a morrer enforcado, mas que, por intervenção do Diabo, conseguiu livrar-se desse trágico fim. Ao tomar conhecimento de seu destino por intermédio da mãe, o menino decide se afastar da família, entendendo que a morte longe desta seria mais facilmente superada. Então, ele corre por cidades e reinos até que se depara com uma capela de São Miguel, na qual havia a imagem deste santo e do Diabo. O príncipe decide restaurar a capela e as imagens, dando ordens expressas para que os obreiros também contemplassem o Diabo, uma vez que este havia sido inicialmente deixado de lado. Findada a obra, pintados santo e Diabo, ele pede abrigo na casa de uma velha a qual, observando-o contar o dinheiro que ainda lhe restava, denuncia-o para o rei sob a acusação de roubo. Eis que o príncipe é condenado à forca. No entanto, ao tomar conhecimento do caso, o Diabo vai à casa da velha e a obriga a desmentir a história, conseguindo, assim, salvar o príncipe do seu destino indesejável. Tudo isso em gratidão àquele que lhe tratou de igual para igual em relação ao santo. Aquele que, contra tudo e contra todos, também assegurou que sua imagem fosse restaurada e pintada com dignidade. 
Como pode se observar, não é possível aferir nenhum atributo maligno ao Diabo de Lobato. Pelo contrário, a sua atitude em relação ao príncipe é mais do que benevolente. Ela também revela um Diabo que possui gratidão, que age desinteressadamente e que tem sede por justiça. Sua gratidão é demonstrada quando ele abandona a capela às pressas ao saber que o condenado à morte na forca era aquele que havia recuperado sua imagem. O seu agir desinteressadamente pode ser observado quando ele não cobra nada do príncipe por ter lhe salvado a vida. E a sua sede por justiça é confirmada quando ele, além de salvar o príncipe, também obriga a velha a confessar a sua mentira ao rei, sendo que este a condena a restituir o dinheiro ao seu verdadeiro dono e a ir para a forca:

...Terminado o caso, o moço partiu novamente a correr mundo.

Pelo caminho encontrou um fidalgo, ao qual contou tudo.

O fidalgo disse:

- E não sabes quem te valeu?

- Não sei de nada - respondeu o príncipe.

- Pois fica sabendo que foi o diabo da capelinha de S. Miguel, e esse diabo sou eu. No dia em que iam enforcar-te, S. Miguel me contou tudo. Montei num cavalo e voei à casa da velha; agarrei-a e levei-a ao rei, para que tudo se esclarecesse.

- E a que devo eu tanta bondade? - perguntou o príncipe.

- Ah! - exclamou o diabo, rindo-se. - Tudo deves àquele bocadinho de tinta que mandaste aplicar sobre minha figura. Agora estás livre da má sina, porque a velha vai ser enforcada em teu lugar. Podes voltar sossegadamente ao reino de teu pai, que nada mais te acontecerá. (LOBATO, 1995, p. 34)

Ainda que o Diabo de Lobato seja muito parecido com o que tradicionalmente se imagina de Deus, em um atributo aquele se difere deste: o personagem diabólico não é onipresente. Ele teve que recorrer a São Miguel para tomar conhecimento de como se deu a restauração de sua imagem e quem foi que a propiciou. Outro detalhe é que não há, no conto lobatiano, nenhuma descrição física do Diabo, conferindo, assim, liberdade ao leitor para imaginá-la. 
Por fim, é possível se fazer uma analogia entre o conto e a história do próprio autor. A partir de 1931, após retornar dos Estados Unidos, Monteiro Lobato foi perseguido, preso e criticado por divulgar a existência de petróleo no Brasil. Na época, havia interesse oficial em dizer o contrário e Lobato acreditava que o povo precisava usufruir desse recurso natural para conseguir uma vida mais digna. Sendo assim, parece que a dedicação do autor à Literatura para crianças pode também ser uma manifestação do seu desgosto para com o público adulto e a censura oriunda do mesmo.

No final do conto, a narradora, Tia Nastácia, confessa não acreditar nesse Diabo bonzinho presente na história, tratando esta como mera ficção e possibilidade de entretenimento. Emília, por sua vez, sai em defesa do Diabo. Para tanto, ela associa o personagem ao melhor amigo do homem em função do termo cão, que Tia Nastácia usa para se referir a ele:

Narizinho confessou que gostava muito das histórias com o diabo dentro, e disse que todas elas confirmavam o dito popular de que o diabo não é tão feio como o pintam.

- Credo! - exclamou tia Nastácia fazendo três benzeduras. - Como é que uma menina de boa educação tem coragem de dizer isso do canhoto?

Narizinho arregalou os olhos.

- Como? É boa! Pois você mesma não acaba de contar a história dum diabo bom?

- Mas isso é história, menina. História é mentira. O "cão" é "cão". Não muda de ruindade.

- Se o cão é cão, viva o diabo! - gritou Emília. Não há animal melhor, nem mais nobre que o cão. Chamar ao diabo cão é fazer-lhe o maior elogio possível. (LOBATO, 1995, p. 34, negrito nosso)

Através da personagem Emília, a boneca que não tem papas na língua, Lobato parece externar tudo aquilo que lhe é censurado pelos homens, bem como contestar as verdades socialmente aceitas. Assim ele o faz em O Bom Diabo, na medida em que ignora a imagem tradicional do personagem enquanto ser maligno e o remonta às avessas, como um ser tão benevolente quanto Deus. 


\section{O Diabo segundo Luis Fernando Veríssimo}

Luis Fernando Veríssimo, nascido em Porto Alegre no ano de 1936, é nacionalmente conhecido por suas crônicas e textos bem-humorados. Seus escritos são bastante difundidos entre os jovens. A coletânea Comédias para se ler na escola foi inclusive uma das obras contempladas pelo vestibular da Universidade Federal de Santa Catarina. Outra das suas coletâneas é Orgias, publicada em 2005. É neste livro que está inserida a crônica Belzebu.com, a qual aborda uma negociação virtual entre o narrador e o inimigo cristão.

A estória tem início com o narrador recebendo um e-mail do Diabo, no qual este dizia estar procurando pessoas dispostas a trocarem suas almas por aquilo que desejassem, uma única coisa. Interessado no negócio, o narrador tem dificuldades para decidir o que desejaria. Inicialmente, pensa na Vera Fischer, depois em uma vitória do Internacional no campeonato e, por fim, acaba optando por um pedido que, ao seu ver, acabaria beneficiando um número maior de pessoas: a transformação do Brasil em um país escandinavo.

A decisão vem após o narrador pensar nos problemas sociais e culturais brasileiros que seriam solucionados com tal transformação: a irresponsabilidade das pessoas, a indecência hipócrita da sociedade, os crimes impunes. Eis uma crítica presente em Belzebu.com aos padrões comportamentais do brasileiro e a problemas sociais que comprometem o desenvolvimento do país.

Quanto ao Diabo de Veríssimo, a grande novidade fica por conta da uma modernização do personagem, posto que a negociação da alma é feita por e-mail. Um detalhe interessante dessa negociação é que o Diabo não precisa fazer muito esforço para convencer o narrador a trocar sua alma, é este quem toma toda a iniciativa. Por outro lado, seu esforço se concentra em fazê-lo pensar em outra moeda de troca, ou seja, em dissuadi-lo da ideia de transformar o Brasil em um país escandinavo. Para tanto, ele coloca seu interlocutor a par das dificuldades que viriam com tal mudança, advertindo que as pessoas precisariam se adaptar à nova língua, à moeda, ao frio, aos hábitos diferentes. Além disso, alerta para os atributos positivos dos brasileiros que seriam deixados para trás: a alegria, a simpatia, a criatividade. Desse modo, fica evidente o interesse do Diabo em conservar as mazelas que afligem o povo brasileiro, portanto, diferentemente do Diabo de Monteiro Lobato, o personagem de Veríssimo conserva a malevolência do seu arquétipo cristão. 
Outra novidade em relação ao Diabo de Veríssimo é que ele não exige que os ganhos da negociação sejam todos para ele, algo inimaginável pelos cristãos mais ortodoxos para um ser que se atreveu a tentar o próprio filho de Deus. Em sua última tentativa de dissuadir seu interlocutor, o Diabo de Veríssimo sugere tornar o Brasil escandinavo durante o expediente e fazê-lo permanecer brasileiro no seu encerramento, ou seja, ele se propõe a resolver os problemas do Brasil parcialmente. Essa opção certamente não excluiria a bebedeira, as festas, o adultério, enfim, situações que potencialmente geram desordem mesmo sendo fora do âmbito profissional. Por fim, o narrador não aceita a proposta, mas ela serve para levá-lo a postergar a mudança do Brasil para depois do carnaval, de modo que ele pudesse a aproveitar a festa popular por uma última vez.

Com Belzebu.com, Luis Fernando Veríssimo conserva a característica malevolente e a condição de tentador do Diabo, mas também inova ao modernizar e nacionalizar a história do personagem. A modernidade reside no fato de o Diabo fazer uso do ambiente virtual para realizar os seus negócios. É justamente por se tratar de um ambiente virtual, que o leitor não conta com nenhum tipo de descrição física. Já a nacionalização está presente na abordagem dos problemas do Brasil e do jeito de ser do brasileiro, o que fica ainda mais evidente no desfecho da história, quando o narrador posterga a mudança do Brasil para depois do carnaval, ou seja, deixa a resolução do problema para em segundo momento.

As duas obras analisadas, O Bom Diabo e Belzebu.com, demonstram uma despreocupação por parte de seus escritores em seguirem os ditames da tradição religiosa ao inserirem o Diabo como personagem em suas obras. Pelo contrário, cada escritor recria o personagem bíblico à sua maneira e de acordo com a proposta de sua obra. Monteiro Lobato engendra um Diabo benevolente, desinteressado e justiceiro, indo abertamente contra a concepção cristã do personagem. Luis Fernando Veríssimo, por sua vez, conserva a imagem do Diabo enquanto tentador. Contudo, seu personagem é um Diabo moderno, que faz uso da internet para negociar almas. Além disso, o personagem de Veríssimo é um negociador, uma vez que aceita abrir mão de um pouco do seu lucro, algo que contraria a intransigência do Diabo bíblico, o tentador de Eva, Jó e Jesus. O Bom Diabo e Belzebu.com, obras que são acessadas pelo público infanto-juvenil brasileiro, o Diabo não é tratado como coisa séria. Pelo contrário, ele é retirado da esfera do sagrado para entreter o leitor, apresentando-se sob formas que demonstram uma total despreocupação com a ortodoxia religiosa: um Diabo às avessas (benevolente), no caso de Lobato; e um Diabo modernizado, no caso de Veríssimo. 


\section{Bibliografia}

BÍBLIA. Português. Edição pastoral. São Paulo: Paulinas, 1990. 1631p.

BÍBLIA. Português. Bíblia de estudo Almeida. Barueri: Sociedade Bíblica do Brasil, 2006. 1728p.

FERRAZ, Salma. O Diabo na literatura para crianças. Linguagens: Revista de Letras, Artes e Comunicação, Blumenau, v. 1, n. 3, p.220-238, 2007. Disponível em: <http://proxy.furb.br/ojs/index.php/linguagens/issue/ view/127/showToc $>$. Acesso em: 01 nov. 2010.

KÜNG, Hans. On being a christian. Tradução de: Edward Quinn. New York: Doubleday, 1976.

LOBATO, Monteiro. O Bom Diabo. In: LOBATO, Monteiro. Histórias de Tia Nastácia. São Paulo: Brasiliense, 1995. p. 33-34. Ilustrações e capa de Manoel Victor.

PINHEIRO, Vanessa Neves Riambau. O trágico e o demoníaco em “O Evangelho Segundo Jesus Cristo", de José Saramago. 2007. 95 f. Dissertação (Mestrado) - Curso de Pós-graduação em Literaturas Brasileira, Portuguesa e Luso-africanas, Departamento de Pós-graduação em Letras, Universidade Federal do Rio Grande do Sul, Porto Alegre, 2007. Disponível em: <http://www.lume.ufrgs.br/handle/10183/10789>. Acesso em: 10 jun. 2010.

SOUZA, Ronaldo Ventura. O Jesus de Saramago e a Literatura que revisita Cristo. 2007. 156 f. Dissertação (Mestre) - Curso de Pós-graduação em Literatura Portuguesa, Departamento de Letras Clássicas e Vernáculas, Universidade de São Paulo, São Paulo, 2007. Disponível em: < http://www. teses.usp.br/>. Acesso em: 10 jun. 2010.

VERÍSSIMO, Luis Fernando. Belzebu.com. In: VERÍSSIMO, Luis Fernando. Orgias. Rio de Janeiro: Objetiva, 2005. p. 136.

\section{Imagens:}

http://noticias.gospelmais.com.br/exorcistas-internet-facilita-trabalhodiabo-18378.html 


\section{O Diabo: O Malfeitor Cósmico}

Raphael Novaresi Leopoldo (UFSC) ${ }^{1}$

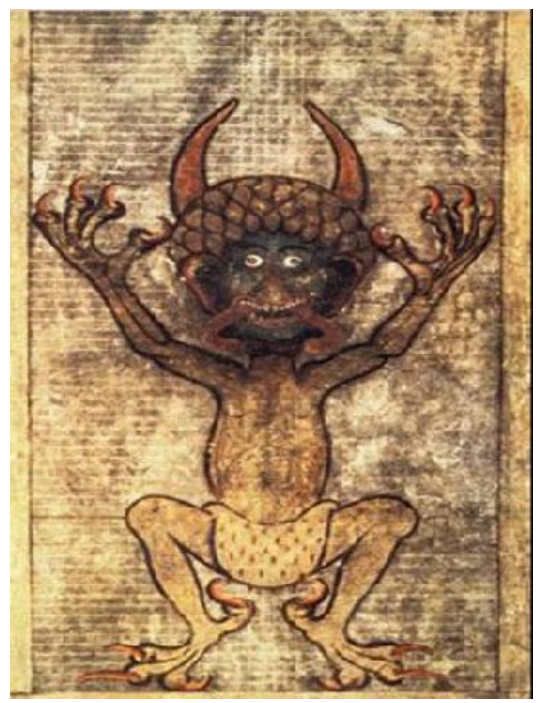

\section{Introdução}

As elucubrações teológicas sobre o ser denominado genericamente de diabo têm sofrido sensível variação desde suas primeiras noções ao hodierno. Sem formular conceito próprio, no vultuoso Dicionário crítico de Teologia, Édouard-Henri Wéber comenta a visão bíblica, patrística e medieval a respeito do diabo curiosamente reservando à contemporaneidade a seguinte colocação: "A modernidade que já tem dificuldade em

1 Mestrando em Literatura da Universidade Federal de Santa Catarina - UFSC e pesquisador do NUTEL _ Núcleo de Estudos comparados entre Teologia e Literatura. E-mail: raphanova@gmail.com. 
considerar seriamente a idéia de a. [anjos], remete na maioria das vezes o d. [demônio] ${ }^{2}$ à superstição mitológica, e os teólogos preferem calar-se a esse respeito." (2004, p. 519)

Em sua Biografia do diabo, Alberto Cousté comenta a atual situação do diabo - ao que parece, com pitada de humor -, sendo resultado da metamorfose mais radicalmente absoluta das já engendradas por este ser3 que o ensaísta identifica como sombra de Deus na história. ${ }^{4}$ A estratégia estaria na

\section{[...] argúcia por que [o diabo] conseguiu con- verter-se finalmente na idéia pura do mal, sem que se precise chamá-lo pelo nome ou dotá-lo de qualquer característica para que presida ao pen- samento dos homens (ainda mesmo daqueles que supuseram que o desaparecimento de sua fantasma- goria tivesse implicado o desaparecimento de sua essência). (COUSTÉ, 1996, p. 243, negrito nosso)}

Do ponto de vista da crítica literária, sublinhe-se, importam os problemas de representação e não questões de credo. No entanto, em possível busca por remotas fontes literárias, pode-se encontrar também o princípio norteador religioso e, com isso, criar-se certo desconforto. Harold Bloom, na introdução de Anjos Caídos (2008, p. 15), adverte sobre esse encontro sacro-literário e as querelas porventura deste surgidas: "Pode-se provocar um grande sentimento de injúria com a observação verdadeira de que o culto ocidental a seres divinos é baseado em vários exemplos distintos, porém relacionados entre si, de representação literária."

Explicite-se também que, no encalço do diabo tanto literário quanto teológico pela vereda dos estudos comparados - portanto, em águas confluentes de áreas a priori divergentes, repita-se, ainda que por razões naturalmente distintas -, já há amplos estudos cronológicos como a obra História Geral do Diabo, de Gerald Messadié. Todavia, é ainda no suscinto Anjos Caídos (2008, p. 15) - cuja edição brasileira se mostra executada

2 O dicionário remete a palavra diabo e seus correlatos à entrada unificada Demônios.

3 Como faz Cousté, este termo é aqui aplicado em sentido genérico, sem levar em consideração a materialidade ou não do referente.

4 O epíteto consta como subtítulo do livro. 
com arte - que Bloom consegue bem formular em poucas palavras essa história, pelo que se apura hoje, de bem mais de dois milênios:

Demônios [I] pertencem a todas as épocas e a todas as culturas, mas anjos caídos [II] e diabos [III] emergem essencialmente de uma série quase contínua de tradições religiosas que começa com o zoroastrismo, a religião mundial dominante durante os impérios persas, e passa dele para o judaísmo na época do Cativeiro da Babilônia e no pós-cativeiro. Há uma transferência bem ambivalente de anjos maus do judaísmo tardio para o cristianismo inicial, e depois uma transformação positivamente ambígua das três tradições angélicas no islamismo, dificil de rastrear, precisamente porque sistemas neoplatônicos e alexandrinos como o hermetismo entram na mistura. ${ }^{5}$

Transformado em personagem, o diabo torna-se presença marcante, em primeiro lugar, nos livros judaico-cristãos tomados como canônicos que hoje compõe a denominada Bíblia, célebre ainda quando não tomada pelo viés religioso, como é o caso do presente escrito, mas pelo status de matriz desse livro. Se, como afirma William Blake seguido por Herman Northrop Frye, em O código dos códigos (2004, p. 15), a Bíblia é o grande código da arte a relacionar-se com a tradição cultural ocidental, convém observar como acontece a transposição de sua imagética aos demais códigos de arte.

Assim migrado, o diabo bíblico passa por diferentes configurações, como aponta a fortuna crítica, sobretudo se contrastadas as duas grandes partes nas quais as Escrituras foram tradicionalmente dividias. Polêmico por natureza, se aqui permitida uma figura retórica, enquanto, no Segundo Testamento, Satã não poupa de provações nem mesmo a divindade naquele contexto, personificada, sobretudo, no Messias -, no Primeiro, marca presença um ser ambíguo, que ao menos se passa por um dos Filhos

5 Convém evidenciar que este crítico utiliza o termo demônios na acepção grega da palavra (daemónia - espíritos de genialidade, inspiração, amigáveis ou não), enquanto seres positivos; já anjos caídos (que envolvem o universo da morte) e diabos (obstaculizadores) como seres negativos. 
de Deus. Nessa conjuntura, cabe uma sintetização de Henry Ansgar Kelly em Satã: uma biografia (2008, p. 365-366, destaque do autor, negrito nosso): ${ }^{6}$

Entre os estudiosos da Bíblia aceita-se de maneira geral que os satãs de Jó e de Zacarias são espécies de funcionários públicos do Tribunal Divino. Mas tal sentimento não inclui o Satã do Novo Testamento. Ao contrário, assume-se que ele é visto como "maléfico" de tal modo que a figura em Jó não é; e que ele é, de fato, um inimigo de Deus assim como do homem, um tipo de Malfeitor Cósmico.

Todavia, seria de se esperar que uma biblioteca ${ }^{7}$ cujos livros foram escritos num intervalo temporal de aproximadamente 13 séculos, com autores sob realidades sociais diversas e sem conhecer muitos de seus pares que viriam a ser consagrados, ausência de originais e número de cópias milenares com variantes textuais tivesse coerência perfeita? No entanto, o reconhecimento de tal constatação parece não mudar o fato de que há lapsos de coerência na obra tida como palavra inspirada. Não obstante, as Escrituras permanecem como uma das mais antigas e boas fontes de literatura relegada à posteridade.

Perseguindo, sem exorcizar, o capiroto pós-bíblico que se encarna e toma posse da literatura declaradamente ficcional, neste breve ensaio, especificamente, busca-se registrar aspectos desse diabo aventureiro fixando os limites das considerações sobre as obras $A$ divina comédia e seu par $A$ divina paródia cujo motivo de escolha se evidenciará na exposição a seguir.

$6 \mathrm{O}$ autor propõe uma nova leitura do diabo bíblico, bem diversa da costumeira, valendose, para tanto, de altas hipóteses. Além disso, a tradução disponível no mercado editorial brasileiro parece revelar falta de apuro e desconhecimento do tradutor para com a área trabalhada por Kelly.

7 Reporte-se aqui ao sentido primevo do termo Bíblia (do gr. biblia, livros; plural de biblion, livro), levando em conta a formulação de que “[...] a Bíblia é uma coleção, muito mais uma biblioteca do que uma única composição literária.” (McKENZIE, John L. Dicionário bíblico. Trad. Álvaro da cunha et. al. 10. ed. São Paulo: Paulus, 2011. p. 112). 


\section{Figuração do ontem, paródia do hoje}

\section{O diabo à florentina: Lo'mperador del doloroso regno}

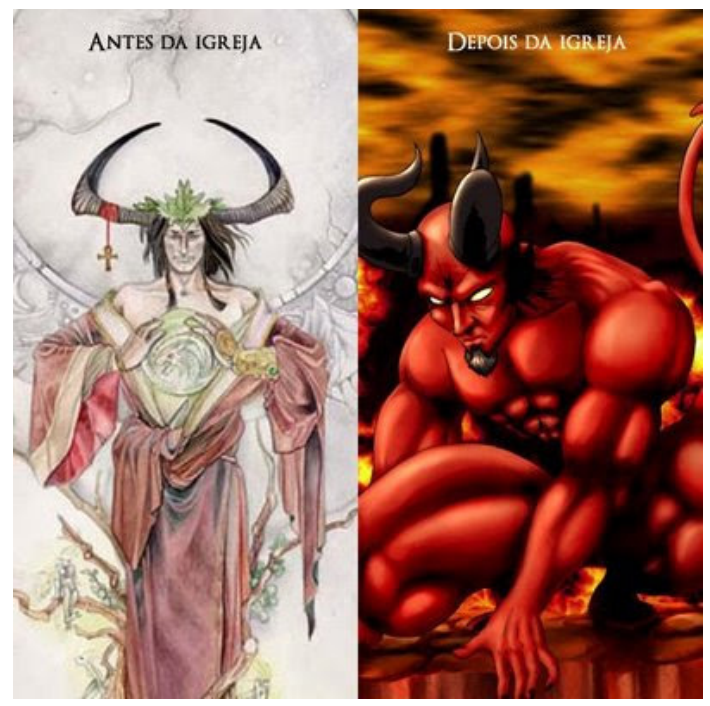

Se, na Bíblia, a figura do diabo não é una e a glosa dos Pais da Igreja ${ }^{8}$ para interpretá-la também não se mostra unívoca (MESSADIÉ, 2001, p. 330-331), uma convergência dessa matéria mista parece acontecer em $A$ divina comédia. Sem delongas na apresentação de tão familiar - ou assim deveria ser - escrito ficcional supostamente cristão, anterior cerca de três séculos ao Paraíso perdido de Jonh Milton, recorde-se as palavras de Otto Maria Carpeaux (2011, p. 11), que podem ser tomadas como resumo da vasta produção crítica publicada a respeito: "A Divina Comédia é um edifício colossal, cuja unidade está garantida pelas convicções religiosas, filosóficas e teológicas do poeta; e pela terza rima."

O alcance de Dante ultrapassa as considerações dos que tratam da aplicação estética da linguagem escrita. É relevante ressaltar que a Commedia granjeou a si uma posição singular entre os livros de ficção que tangem o sagrado e o epíteto de teólogo ao seu autor. Dante consta

8 Tratam-se de célebres figuras da igreja cristã primitiva consideradas referências no anúncio e exposição de fé cuja produção (c. séc. II a VIII) estabeleceu a base doutrinal da Igreja. (DROBNER, Hubertus. Manual de Patrologia. Trad. Orlando dos Reis e Carlos A. Pereira. 2. ed. Petrópolis, RJ: Vozes, 2008. p. 11-14). 
até mesmo como verbete em dicionários teológicos. No já citado anteriormente, por exemplo, Imbach e Maspoli (2004, p. 506ss) tratam d'A divina comédia como síntese teológica de Dante e como que endossam Carpeaux: "Verdadeira Summa do saber, misturando muitos gêneros literários, em particular a visão e a literatura de viagem, o poema é a expressão multiforme de uma experiência simultaneamente poética, filosófica e teológica [...]."

Entretanto, ressalve-se que tal teologia não pode ser restrita à cristã. Mesmo considerando os séculos de exegese sobre $A$ divina comédia, Cousté adverte quanto à polissemia ainda indecifrada a brotar do célebre livro tal qual manancial enigmático. Nesse aspecto, de modo incisivo, Bloom (2001, passim) sinaliza ir ao encontro de Cousté, porém, enquanto aquele parece conciso, este se mostra amplo e categórico:

Para além de sua fachada ortodoxa, a Comédia denuncia a cultura e a excepcional intuição de um homem cujo pensamento estava acima de qualquer dogmática: os elementos pitagóricos, islâmicos, persas, cátaros e do gnosticismo alenxandrino que aparecem em toda parte da obra [...] deixam supor uma profunda preparação esotérica, e até iniciática, que ilumina de maneira especial a estrutura da obra e as intenções do autor. (COUSTÉ, 1996, p. 202, itálico do autor)

O Inferno dantesco, primeira grande parte do poema, é apresentado ao leitor como "profundo fosso doloroso/ que acolhe o eco de infinitos ais" (IV,8-9). ${ }^{9}$ Destino e morada de pecadores incorrigíveis em vida, aquela "selva de espíritos espessa" (IV,66) é assombrada por diabos-monstros que incessantemente supliciam os condenados a ela. No quadro dessa espécie de funcionários do horror, figuram, sobretudo, personagens mitológicas: Caronte (Canto III), Minós (Canto V), Cérbero (Canto VI), Pluto (Canto VII), Flégias (Canto VIII), Fúrias (Canto IX), Minotauro (Canto XII), Harpias (Canto XIII), Gerion (Canto XVII).

9 Faz-se, neste artigo, referência à tradicional tanto de A divina comédia (por canto, em numerais romanos, seguido de verso(s), em arábicos) quanto dos livros bíblicos (por capítulo seguindo de versículo(s)), tornando fácil a consulta nas mais diversas edições. 
Porém a personagem preponderante é Lúcifer, o diabo-mor, por assim dizer.

O leitor que busque pela aparência do rex inferni o encontra ambientado em sua própria cova, ela e ele denominados Dite, ambos sob forte construção imagética ainda hoje, mesmo quando até o diabo encontra-se estereotipado. Que poete o próprio vate florentino:

Mas foi o meu assombro inda crescente quando três caras vi na sua cabeça: toda vermelha era a que tinha à frente, e das duas outras, cada qual egressa do meio do ombro, que em cima se ajeita de cada lado e junta-se com essa, branco-amarelo era a cor da direita $\mathrm{e}$, a da esquerda, a daquela gente estranha que chega de onde o Nilo ao vale deita.

Um par de grandes asas acompanha cada uma, com tal ave consoantes:

- vela de mar vira eu jamais tamanha essas, sem penas, semelhavam antes às dos morcegos, e ele as abanava, assim que, co'os três ventos resultantes, as águas de Cocito congelava.

Por seis olhos chorava, e dos três mentos sangrenta baba co'o pranto pingava. (XXXIV,37-54)

Contudo há mais n'A divina comédia que imagens impactantes, ou seja, “[...] a alegoria é utilizada num sentido ao mesmo tempo poético e teológico" (IMBACH e MASPOLI 2004, p. 506). Erguendo-se ligeiramente o véu, por exemplo, ali o Inferno é o triste reino (XXXIV,28) do infeliz Lúcifer, assim porque espelhado na desgraça - descontextualizada - que a tradição da Igreja sustenta ler na Bíblia, por exemplo, em Isaías 14. Explicitamente, além de outros pontos, em Dante é Lúcifer:

- o anjo caído (caíste do céu, foste atirado à terra - Is 14,12), poeticamente cuja queda cavou o fosso no qual situa-se o Inferno: "Para esta parte ele caiu do céu,/ e a terra toda, que aqui se estendia, / por medo dele fez do mar um véu" (XXXIV, 121); 
- o portador da luz (estrela d'alva, filho da aurora - Is 14,12) que, caído, passa a ser o horrendo arauto das trevas: "Se belo foi quão feio ora é o seu modo [...]" (XXXIV, 34);

- o rebelado deflagrador de todo mal (fazia tremer a terra, abalava reinos - Is 14,16), assim Iahweh escapa incólume de páginas difíceis da Bíblia, na qual a divindade pactua com flagelos: "[...] e contra o seu feitor ergueu a frente,/ só dele proceder deve o mal todo" (XXXIV, 35-36).

Complementando tais colocações, cabe destacar que o florentino consegue injetar nos versos de sua celebrada obra a grande questão teológica do mysterium iniquitatis, diante da qual nem a Igreja, mesmo após dois mil anos de catolicismo, tem dado suficiente remate, malgrado o esforço de Pais, papas e concílios.

\section{O diabo antigo em tempos novos}

Do docente, crítico literário, ensaísta e romancista brasileiro de Batatais (SP) Álvaro Cardoso Gomes, $A$ divina paródia revela ao que vem já no título: a palavra de ordem é parodiar declaradamente e, especialmente, $A$ divina comedia. $\mathrm{O}$ romance, publicado pela vez primeira em 2002, é uma obra às avessas que narra as desventuras do anti-herói Diogo Cão pelo mundo transformado nos lugares escatológicos de inferno, purgatório e céu que mais parecem imagens invertidas. Em tais errâncias, o protagonista é guiado pelo diabo Astarot, figura ímpar. A estrutura da obra ajusta-se com exatidão ao traçado por Linda Hutcheon (1998, p. 165): “A paródia não é a destruição do passado; na verdade, parodiar é sacralizar o passado e questioná-lo ao mesmo tempo. E, mais uma vez, esse é o paradoxo pós-moderno."

É no inferno instalado no Sagrado Pulmão de Jesus, colégio católico no qual vive-se em meio a padres autoritários com ares de pedófilos e alunos internos insubordináveis e sodomitas, que Diogo Cão, após uma confissão sacramental, entristecido por nunca haver cometido um pecado mortal, busca conhecer o avesso da pureza. Profanando o sacrário ao mexer indevidamente nas hóstias, a personagem finalmente alcança o intento perdendo o Espírito Santo em favor de Astarot, seu diabo da guarda, de quem será apresentada, nos parágrafos que seguem, cinco das múltiplas facetas. 
No primeiro contraste com seu par homólogo italiano, ou seja, Lúcifer, o filho das trevas d'A divina paródia que se apresenta a Diogo Cão é um diabo amistoso, até mesmo atendendo por apelido: "[...] o demônio lhe disse [a Diogo Cão], sorrindo amistosamente: sabe que gostei de você? Acho que seremos bons amigos. Como você se chama? Diogo Cão perguntou. Astarot, mas pode me chamar de Asta."10 (GOMES, 2002, p. 127). Assim sendo, enquanto em Dante o diabo é sinônimo de castigo, em Gomes há o diabo cúmplice, mesmo sem laços ou vestígios de laços de pacto algum, como em Johann Wolfgang von Goethe ou João Guimarães Rosa.

Se a perspectiva adotada pela Commedia é a de direita, ou seja, a do céu, na Paródia, as ações partem do ponto de vista de esquerda, isto é, do inferno. Em Gomes, o diabo é teólogo, sabendo se posicionar adequadamente quando a argumentação sobre questões fé se faz necessária. São palavras de Astarot instruindo Diogo Cão: "Veja bem: um homem comete um pecado mortal, ofende a Deus; neste caso, deveria ser nosso aliado, não é? Não tem cabimento você, como um bom demônio, se meter a castigá-lo." (GOMES, 2002, p. 128). Aliás, tal alegação ratifica a amistosidade e a cumplicidade destacadas anteriormente. Ante o questionamento de Diogo Cão (que inicia o diálogo no excerto abaixo), Asta vai mais a fundo em suas concepções diabólicas:

Mas os demônios não são criaturas inventadas por Deus para punir os homens? Quem lhe disso isso? Nunca vi maior tolice. Se Deus é o ser supremo, a suprema Beleza, o supremo Bem, como poderia ter criado seres tão horrendos como nós? Se quer saber, Deus e o diabo pertencem a departamentos diferentes... (GOMES, 2002, p. 128, negrito nosso)

Pode-se perceber que, pelo teor da explicação dirigida a Diogo Cão, valendo-se aqui, uma vez mais, de linguagem literária, o diabo de Gomes

10 É próprio de $A D P$, como nas obras de José Saramago a partir de Memorial do Convento, o fato de não haver parágrafo e travessão indicando diálogos ou ainda delimitando interpolações do narrador além de outras questões de estilística, como o que Hutcheon (1998) nomeia de deslocamentos da narrativa (ora a estória é contada por um narrador em primeira pessoa, ora em segunda, causando interferência). 
sugere ter adotado por leitura e estudo a bibliografia proscrita pela Igreja constante no outrora temido Index Librorum Prohibitorum ${ }^{11}$ e se debruçado mormente, sobre Il diavolo, de Giovanni Papini, ${ }^{12}$ cuja conversão no final da vida não anulou sua arguta refutação a demonologia cristã imposta ao diabo.

Todavia, o diabo de Gomes é inconstante. Contrastando com sua boa argumentação em matéria teologal, Astarot revela-se, muitas vezes, ser um diabo tolo, semelhante a personagens de fábulas infantis ou, no mínimo, carente no quesito vocabulário de língua portuguesa. Isso se deduz de passagens tais como (diálogo iniciado por Diogo Cão): “[...] não sabia que você podia metamorfosear-se... Meta o quê? Metamorfosear-se, isto é, transformar-se em quem quiser. Não é muito dificil, principalmente em se tratando de sua pessoa." (GOMES, 2002, p. 129-130). Não menos burlesco mostra-se o diálogo (também começado pelo anti-heroi):

[...] puxa, sempre pensei que os demônios tivessem o poder da ubiqüidade. Ubi o quê? U-bi-qüi-da-de, a capacidade de estar em vários lugares ao mesmo tempo. Quem lhe disso isso? Perguntou Astarot, arregalando os olhos. Jamais vi um diabo que pudesse fazer tal coisa. Aliás, nós, diabos, ao contrário do que pensa o senso comum, somos muito limitados, ainda que saibamos alguns pequenos truques que, mais tarde, posso the mostrar. (GOMES, 2002, p. 128)

Nessa paródia pós-moderna, o diabo também pode mostrar-se horrendo, apesar de apelar para isso apenas em casos extremos, quando a situação o requeira. Em tais casos, tem-se o que se poderia definir como diabo travestido. Eis uma cena ilustrativa:

Mal Diogo Cão e Astarot saíram do colégio, a primeira providência que o demônio tomou foi a de metamorfosear-se num moço loiro. Quando o jovem the perguntou por que fazia aquilo, ele

11 Relação oficial de livros cuja leitura era proibida pela Igreja a seus fiéis por considerá-los perigosos à fé e a moral tida por genuína. Foi abolido por Paulo VI em 1966.

12 PAPINI, Giovanni. Il diavolo: appunti per uma futura diabologia. 12. ed. Firenze: Vallecchi, 1954. 
explicou: e você acha que eu iria passear por aí fantasiado de capeta? [...] Repentinamente, foram abordados por um trombadão que os ameaçou com um estilete. Vendo que não tinham nada de valor, forçou-os a ir atrás de uma grande moita, onde tentou sodomizá-los. Astarot ficou tão aterrorizado que voltou atrás em sua metamorfose; como resultado, conseguiu que o trombadão se escafedesse, assustado com os cornos e as presas do demônio. (GOMES, p. 136-137)

Para concluir esta seção, convém registrar um interessante aspecto paródico da Commedia. O verso latino que Alighieri (XXXIV,1) põe nos lábios de Virgílio para abrir a visão de Dite - Vexilla regis prodeunt inferni trata-se de uma clara paródia do conhecido hino de Fortunato Venanzio, bispo de Poitiers no séc. VI - Vexilla regis prodeunt crucis. Em outras palavras, enquanto, em cada sexta-feira santa, ${ }^{13}$ a Igreja solenemente canta proclamando a realeza de Cristo pela Cruz, o inferno entoa a realeza do diabo pela queda. Caso fosse preciso uma referência em mesmo tom para o Sagrado Pulmão de Jesus, seria cabível algo do gênero Abaixo à tradição, abaixo à ortodoxia inclusive a diabólica.

Assim como a concepção religiosa do diabo foi se alterando com decorrer dos tempos, o condenado que habita as páginas da literatura, sempre inexorável, dá mostras de migração figurativa. Em outras palavras, com a mudança do homem, que concebe ou pensa o diabo, altera-se, em proporção semelhante, também o maligno. E assim como o homem, mudado e mutante, o tinhoso reconfigurado continua a ser retratado pela literatura, como não poderia deixar de sê-lo. Que há possibilidades cênicas mil $A$ divina paródia pode atestar por si.

Em outro sentido, se a face de Iahweh tem recebido novos contornos e expressões, esmaecendo o Deus-Tremor para ênfase no Deus-Amor, por exemplo, porque o diabo deveria permanecer o mesmo? Mudando, o diabo mostra-se que, como Deus, não pode ficar obsoleto. Aliás, ao que parece, o diabo sempre fora mais flexível e dinâmico que seu divino Criador, no que talvez seja Deus que tenha adotado estratégias de seu filho-oponente. Em certo sentido, a inversão pelo riso, como no caso do gênero paródico, pode dizer mais do que aparenta em primeira análise.

13 Trata-se da sexta-feira da Paixão, que antecede a Páscoa. 


\section{Bibliografia}

ALIGHIERI, Dante. A divina comédia. Tradução, comentários e notas de Italo Eugenio Mauro. São Paulo: 34, 2009.

La divina commedia. 13. ed. riveduta e migliorata. Testo critico della Società Dantesca Italiana riveduto col commento Scartazziniano rifatto da Giuseppe Vandelli. Milano: Ulrico Hoepli: 1946.

BÍBLIA de Jerusalém. Ed. rev. e ampl. 7. reimpressão. São Paulo: Paulus, 2011.

BLOOM, Harold. Anjos caídos. Ilustrações Bruno Liberati. Trad. Antonio N. Machado. Rio de Janeiro: Objetiva, 2008.

O cânone ocidental: os livros e a escola do tempo. Rio de Janeiro: Objetiva, 2001.

CHAVES JUNIOR, Edgard de Brito Chaves. Dicionário biográfico de personagens dantescos: biografia de todos os personagens da Divina comédia de Dante. Rio de Janeiro: Forense, 2009.

COUSTÉ, Alberto. Biografia do Diabo: o Diabo como a sombra de Deus na história. Trad. Luca Albuquerque. Rio de Janeiro: Record; Rosa dos Tempos, 1996.

FRYE, Northrop. O código dos códigos: a Bíblia e a Literatura. Trad. Flávio Aguiar. São Paulo: Boitempo, 2004.

GOMES, Álvaro Cardoso. A divina paródia: ou a vida e as grandes aventuras do herói bastardo Diogo Cão pelos quatro cantos do mundo e do que lhe sucedeu nessas andanças. São Paulo: Globo, 2002.

HUTCHEON, Linda. Poética do pós-modernismo. Rio de Janeiro: Imago, 1998.

KELLY, Henry Ansgar. Satã: uma biografia. São Paulo: Globo, 2008.

LACOSTE, Jean-Yves (dir.). Dicionário crítico de Teologia. Tradução de Paulo Meneses et al. São Paulo: Paulinas; Loyola, 2004. 


\section{Imagens}

O Diabo medieval: Disponivel em http://www.acemprol.com/download/ file.php?id $=6555 \& \mathrm{t}=1$

O Diabo antes e depois da Igreja: Disponivel em http://2.bp.blogspot. com/_qKkgxTBqGjU/Sd-ACuEOZNI/AAAAAAAAACQ/lfjIzXTsoSk/ s400/A+Verdade+sobre+o+Diabo.jpg 



\title{
A figura do Diabo nos Sueños de Quevedo
}

\author{
Andréa $\operatorname{Cesco}^{1}$ (UFSC)
}

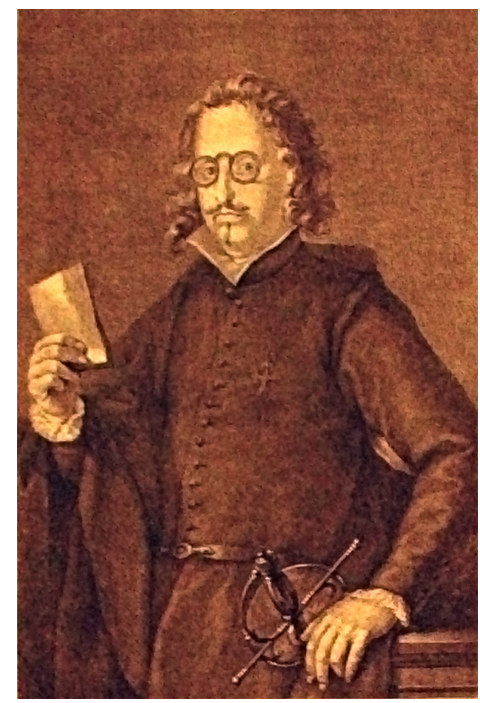

Este artigo tem por objetivo principal analisar a figura do diabo na obra satírica Sueños, escrita no século XVII pelo espanhol Francisco de Quevedo y Villegas, com base na reconhecida edição de James Crosby (Sueños y discursos. Madrid: Castalia, 1993). Também buscaremos analisar os traços típicos do estilo satírico, como a presença de palavras e expressões idiomáticas da língua coloquial e vulgar e a produção de burlas e humor. Este estilo se caracteriza pela reiteração direta ou por repetições com variantes de lexemas predicados para os mesmos sujeitos. O conceito

1 Professora Adjunta do Departamento de Língua e Literatura Estrangeiras e da PósGraduação em Estudos da Tradução da Universidade Federal de Santa Catarina. Email: andrea.cesco@gmail.com 
no discurso satírico é construído sobre o jogo de palavras ou metáforas (ou uma combinação destas com outras figuras) com o propósito de produzir riso no leitor e, ao mesmo tempo - pelo menos em alguns casos -, convidá-lo a refletir sobre a terrível realidade que se apresenta.

A obra Sueños é composta por cinco narrativas, porém nos focaremos no "Alguacil endemoniado" e no "Infierno", textos que satirizam costumes e personagens de todas as classes sociais, através da figura do diabo, e que são extremamente criativos no uso da linguagem coloquial, pois proporcionam o retrato da realidade social da Espanha no século XVII.

\section{"Alguacil endemoniado"}

No primeiro texto, "Alguacil endemoniado", que é uma forte sátira à igreja, temos um diálogo entre o narrador, o bacharel e o diabo, que ocupa a maior parte do discurso e que desempenha o papel principal. A história inicia quando o narrador entra na igreja de São Pedro e encontra o bacharel Calabrês, que é descrito de forma bastante detalhada, entregue a sua ocupação favorita, exorcizando um demônio de um meirinho (alguacil). Esse demônio concede uma breve trégua a sua vítima e conta aos dois, narrador e Calabrês, como vão os clientes no inferno. Ou seja, o próprio demônio que possui o meirinho é quem descreve os diferentes lugares do inferno.

O narrador faz ao diabo uma série de perguntas do tipo "Há reis no inferno?", "Que tipos de penas dão aos poetas?", "E as mulheres, quais são mais condenadas, as feias ou as bonitas?” (tradução nossa). ${ }^{2} \mathrm{E}$ o diabo the responde com uma série de descrições burlescas, dando a entender o caráter geral do inferno e afirmando a superioridade moral e intelectual dos diabos sobre a maioria dos homens.

O diálogo, muitas vezes, se converte num sermão moralizante sobre os benefícios da pobreza, a arte de governar etc. Nesse texto aparecem avaros, médicos, poetas, damas honestas ou não, comerciantes, pasteleiros, administradores da justiça, cornos, e aparecem também os apaixonados. É importante destacar que nesse texto os condenados estão agrupados segundo analogias engenhosas: o cego está entre os apaixonados, um assassino está entre os médicos, os mentecaptos junto aos alquimistas, e os negociantes, condenados por vender, estão com Judas.

2 “¿Hay reyes en el infierno?”, “¿Qué géneros les dan de penas a los poetas?”, "Y las mujeres, ¿cuáles se condenan más, feas o hermosas?” 
Segundo Crosby (QUEVEDO Y VILLEGAS, 1993, p. 28), a sátira de Calabrês como exorcista que tenta calar um diabo coincide com a crítica que Quevedo faz no prólogo dos que se calam por temor, dos que procuram deixar outros mudos, e daquelas más línguas que alimentavam um ambiente de repressão religiosa. Aqui, segundo o crítico, está o tema da expressão e da repressão, em que o narrador apóia a expressão, coincidindo com as palavras de Quevedo no prólogo ao leitor, em que elogiava a ousadia dos que se atrevem a publicar suas ideias. Esse texto é uma sátira à igreja, que não fica no mero plano abstrato.

No entanto, é importante fazer um aparte para explicar quem é o alguacil e o que ele fazia nessa época, já que chegam a inspirar os mais sangrentos sarcasmos do satírico barroco. O meirinho e os seus subordinados - os beleguins -, são agentes da lei que colocam em marcha o procedimento criminal e que no civil executam os mandamentos do juiz. Nesse texto, Quevedo parte da base das notáveis afinidades entre meirinhos e demônios, e enumera até seis ordens conhecidas de meirinhos, que vêm a coincidir com as potências demoníacas: Os ígneos, os aéreos, os terrenos, os aquáticos, os subterrâneos e os lucífugos (QUEVEDO Y VILLEGAS, 1993, p. 154).

Os ígneos são de natureza violenta e criminal, que perseguem o gênero humano a sangue e fogo; que perseguem os réus pelas ruas para agarrá-los e culpá-los, levantando falso testemunho. Os aéreos são os que sopram, pois são os delatores profissionais (os beleguins também são acusados de denunciar). Os terrenos são os civis, que à força de comissões e execuções destroem a terra; estes roubam o povo mediante a falsificação de embargos judiciais. Os aquáticos são os encarregados do cumprimento das ordenanças municipais em matéria de sanidade e polícia, prendendo o sujeito se este esvazia ou não as imundices pelas portas e janelas, sem dizer "Vai água!", ${ }^{3}$ e assim costumam ser chamados porque quase todos são bêbados e sequiosos por vinho. Os subterrâneos são os investigadores de vidas, fiscais de honras e levantadores de falsos testemunhos, que debaixo da terra arrancam o que acusar, e andam

3 No século XVI ao XVIII costuma-se esvaziar as águas imundas de cada casa diretamente na rua, antecipadas pelo grito de 'Vai água!', avisando assim os que passeiam pela rua. As autoridades de Madri tentaram repetidamente limitar as horas de lançar as águas para altas horas da noite (quando menos pessoas passeavam) e proibir que fossem jogadas de janelas altas (nota do editor - Crosby). 
sempre desenterrando os muertos e enterrando os vivos (QUEVEDO Y VILLEGAS, 1993, p. 156). Os últimos são os lucífugos, os que fazem as rondas noturnas para manter a ordem e vigiar as cidades, e estes fogem da luz porque ela pode denunciar as suas falcatruas; no entanto, a luz, que representa a iluminação interior e o juízo, e tudo que é bom e santo, é que deveria fugir deles.

Retomando o texto "Alguacil endemoniado", Calabrês na passagem abaixo se enfurece com o diabo que não quer se calar, e jogando-lhe água benta nas costas professa palavras para esconjurá-lo; este, porém, começa a gritar tentando escapulir. A partir daí o próprio diabo explica ao clérigo que o meirinho tenta escapar por causa da água e não da benzedura, e o faz detalhando a etimologia da palavra alguacil, pois esta se assemelha fonologicamente a água. E para Quevedo os alguaciles, além de mentirosos e usurpadores, eram bêbados que, evidentemente, não suportavam a água.

Clérigo, cata que no hace estos sentimientos el alguacil por la parte de bendita, sino por ser agua: ¿Hay cosa que tanto aborrezcan los alguaciles? Pues aun por no verla en su nombre llamándose propiamente 'aguaciles', han encajado una ele en medio, llamándose 'alguaciles'. Y por qué acabéis de conocer quién son y cuán poco tienen de cristianos, advertid que de pocos nombres que del tiempo de moros quedaron en España, llamándose ellos 'merinos', le han dejado por llamarse 'alguaciles', que es palabra morisca, 'guacil'; y hacen bien, que conviene el nombre con la vida y ella con sus hechos (QUEVEDO Y VILLEGAS, 1993, p. 163).

Então, para os alguaciles a água lhes aborrece tanto que para não escutarem essa palavra, ao ser pronunciado alguacil, colocaram um "l" no meio, já que sem ela soaria "agua-cil". Crosby, em nota de rodapé, explica que essa palavra deriva de wasir (árabe: ministro, visir), precedido pelo artigo árabe, "al"; e acrescenta que a partir do Poema del Cid surgiu em espanhol o vulgarismo aguazil, empregado ainda por alguns copistas no século XVII. Quevedo, para fazer uma piada com a palavra água, inverteu o processo de vulgarização, atribuindo a intercalação da letra "l" à vontade dos alguaciles. 
Nessa outra passagem, o alguacil endemoniado (o meirinho que está com o diabo no corpo) vira diabo alguacilado; ou seja, contrariamente à expectativa é o diabo que vai estar com o meirinho no corpo. Ao longo do texto o diabo manifesta nitidamente uma atitude de superioridade intelectual em relação aos homens. E Quevedo desumaniza os meirinhos, colocando-os numa situação inferior; ademais, se queixa de que o contato com eles resulta degradante para os diabos. A correspondência entre as funções diabólicas e meirinhais descansa no fato de que ambas se fundamentam em querer o mal dos humanos.

Y hase de advertir que los diablos en los alguaciles estamos por fuerza y de mala gana, por lo cual, si queréis acertar, me debéis llamar a mí diablo alguacilado, y no a éste alguacil endemoniado (QUEVEDO Y VILLEGAS, 1993, p. 161-2).

O estilo de Quevedo é rico também em neologismos, muitos deles produzidos pelo cruzamento de palavras. E esse tipo de invenção verbal é no satírico um elemento lúdico que contribui para o efeito de comicidade. Emilio Alarcos García, no artigo "Quevedo y la parodia idiomática", ${ }^{4}$ diz que as paródias são "flor e fruto do espírito corrosivo e zombador de Quevedo, da sua mentalidade de escolástico habituado ao discurso afiado e à argumentação refinada, e de sua fantasia deformadora e desrealizadora de coisas e atitudes". ${ }^{5}$ (tradução nossa)

No entanto, pelos parágrafos dos Sueños, além dos meirinhos infames, desfilam outros agentes da justiça, como juízes e escrivães corrompidos, relatores desonestos, advogados desleais, toda uma tipologia que nos transporta a uma realidade cujas dimensões, segundo Gacto Fernández (in GARCÍA DE LA CONCHA, 1996, p. 133-4), dificilmente seríamos capazes de captar mediante o exame das fontes jurídicas, normas, documentos e sentenças.

Quevedo critica nos juízes a tentação mais perigosa do seu oficio, a cobiça. Gacto Fernández ressalta que num sistema normativo de

4 Centro Virtual Cervantes - Las sátiras de Quevedo y su recepción: antología crítica. Recopilación de Lía Schwartz. http://cvc.cervantes.es/obref/quevedo_critica/satiras/alarcos.htm

5 “flor y fruto del espíritu mordicante y burlón de Quevedo, de su mentalidad de escolástico avezado al discurso afilado y a la argumentación sutilizante, y de su fantasía deformadora y desrealizadora de cosas y actitudes". 
contornos difusos havia muitas brechas para o jogo do arbítrio judicial, (in GARCÍA DE LA CONCHA, 1996, p. 138). Assim era possível ao julgador manter diversas e até contrárias interpretações de um mesmo texto, e se inclinar pela solução mais benéfica aos interesses do corrupto, sem escândalo, ou pelo menos, sem evidência de suborno.

Neste fragmento, os juízes estão associados à comida; estes são para o inferno e para os diabos o prato mais saboroso: faisão, ave galinácea notável pela excelência da carne. E também a melhor semente, pois é a que mais frutos dá aos diabos. E fruto aqui tem não só o sentido de produto da terra para sustento e beneficio do homem (dos diabos), como também no sentido de dar lucro, vantagem, resultado. E o diabo conclui que se o ano é fértil de trapaças, não há silo suficiente no inferno para recolher o fruto de um mau ministro.

Los jueces son nuestros faisanes, nuestros platos regalados, y la simiente que más provecho y fruto nos da a los diablos; porque de cada juez que sembramos cogemos seis procuradores, dos relatores, cuatro escribanos, cinco letrados y cinco mil negociantes, y esto cada día. De cada escribano cogemos veinte oficiales; de cada oficial, treinta alguaciles; de cada alguacil, diez corchetes; y si el año es fértil de trampas, no hay troj en el infierno donde recoger el fruto de un mal ministro (QUEVEDO Y VILLEGAS, 1993, p. 176-7).

Nesse trecho, quando o diabo fala sobre a acomodação das pessoas no inferno, feita de forma ordenada, levando em conta as afinidades que as combinam, Quevedo utiliza ironicamente os homógrafos. ${ }^{6}$

Y en el infierno están todos aposentados con tal orden que un artillero que bajó allá el otro día, queriendo él que lo pusieran entre la gente de guerra, como al decir el oficio que había tenido, dijese que hacer tiros, fue remitido al cuartel de los escribanos, pues son los que hacen tiros en el mundo. Un sastre,

6 Palavra que tem a mesma grafia de outra, mas significado diferente. 
porque dijo que había vivido de cortar de vestir, fue aposentado con los maldicientes; [...] (QUEVEDO Y VILLEGAS, 1993, p. 167).

$\mathrm{Na}$ primeira parte, que se refere ao soldado de artilharia, o diabo diz que ele queria que o pusessem entre gente de guerra, porque seu oficio havia sido dar "tiros", disparar projétil; porém foi enviado para onde estavam as tropas de escrivães, porque "tiro" significa também, segundo o Diccionario de Autoridades, de 1739, furto, ou grave dano físico ou moral; ou ainda "decepção ou zombaria, enganar alguém maliciosamente". Ou seja, os escrivães são acusados de alterar os depoimentos das testemunhas, agem de má-fé, porque o que importa e prevalece não é a verdade e sim a vontade de quem os suborna.

Na sequência, o alfaiate também será encaminhado para o lugar certo no inferno, com aqueles que armam intrigas ou confusões; e isso porque ele viveu de "cortar de vestir", ou seja, maldizer, difamar. O Diccionario de Autoridades, de 1729, nos mostra dois significados para essa expressão: "fazer vestidos, cortá-los e cosê-los: o que é próprio do ofício dos costureiros" ou "metaforicamente se toma por murmurar e falar mal de alguém”.

\section{"Infierno"}

Quanto ao segundo texto, "Inferno", que é o mais longo e mais complexo, o narrador desce pessoalmente para conhecer as mansões infernais. Tema e título remetem, como atesta Nolting-Hauff, de modo especialmente claro, a Dante. " Talvez a influência de Dante em Quevedo também possa ser explicada por este ter evitado a ficção do sonho e ter escolhido em seu lugar uma introdução alegórica" (1974, p. 22-3) (tradução nossa). ${ }^{8}$ Entretanto, há um ponto em que ele se afasta da tradição dantesca: a figura do poeta no sonho não tem acompanhante ou guia.

7 Um estudo de Rodrigo Cacho Casal oferece novas evidências e análises na interação entre os escritos de Dante e Quevedo. Dante y Quevedo: la Divina Commedia en los Sueños. Manchester: Manchester Spanish \& Portuguese Studies: Cañada Blanch, 2003.

8 Quizá también se pueda explicar por la influencia de Dante el que Quevedo evitara la ficción del sueño y eligiera en su lugar una introducción alegórica" (1974, p. 22-3). 
O panorama agora é mais extenso, mas os motivos quase não variam. $\mathrm{Na}$ introdução desse sonho é descrita uma paisagem agradável e dela partem dois caminhos; logo saberemos que um deles é o caminho da virtude e o outro conduz ao inferno. Ingressando o narrador pelo caminho do bem, mas demonstrando não estar satisfeito com a sua escolha, por ser este um caminho muito penoso, decide mudar, mas não percebe que a sua escolha o leva diretamente ao inferno. E quando se dá conta já é tarde para voltar.

Gómez-Quintero (1978, p. 78-9) chama a atenção do leitor, porque até este momento o narrador está situado no mesmo plano que os demais: escolhe o caminho mais fácil e por ele se lança como um condenado ao inferno. Porém, a partir de agora visitará o inferno como um espectador. E no final do texto, de condenado ele passa a mensageiro de Lúcifer, mudando completamente a sua posição. Além disso, ele muda frequentemente de atitude e por várias vezes titubeia: não sabe qual caminho seguir, escolhe um caminho, depois desiste e muda; e quando chega ao inferno muda totalmente de atitude: julga, repreende e zomba dos condenados porque não está entre eles; fala de um ponto de vista de quem está seguro de não pertencer ao grupo repreendido. E é esta atitude, de espectador-crítico, que mantém em todos os sonhos.

O texto se desvia do caminho da virtude e segue a história entre juízes, hipócritas, mulheres, eclesiásticos, soldados, boticários. Os diabos repartem castigos numa série heterogênea que inclui açougueiros, fidalgos, tintureiros, cornos, canhotos, taberneiros, poetas, alquimistas e astrólogos. Aparecem Lutero, Maomé e Judas. No entanto, aparecem alguns retratos novos como os "mortos de repente", que por morrerem de forma repentina não tiveram tempo de se arrepender dos pecados, e os "Oh, quem me dera tivesse", que confiaram na misericórdia de Deus, e agora isso se converte em motivo de condenação para eles. No mais, Quevedo vai continuar agitando os mesmos fantoches das formas mais variadas e originais.

Nessa passagem do "Infierno", vamos encontrar vários jogos alusivos. Nela o diabo acusa os comerciantes de ladrões porque estes, em vida, sempre procuraram tirar vantagem de qualquer negócio realizado, usando as "varas" (antiga unidade de medida de comprimento / instrumento de madeira usado para medir) fraudulentas e impostoras. 
“- Pensaron los ladronazos que no había más, y quisieron con la vara de medir hacer lo que Moisés con la vara de Dios, y sacar agua de las piedras”. (QUEVEDO Y VILLEGAS, 1993, p. 214).

Quevedo faz uma alusão a uma passagem da Bíblia em que Moisés, estando em Horebe, fere a rocha com sua vara (bastão) e dali retira água para o povo beber (Êxodo, capítulo 17, versículos 2 a 10). Os comerciantes, segundo o diabo, querem fazer o mesmo que Moisés, e tirar água de pedras, ou seja, através das varas fraudulentas eles usam todos os meios e se empenham para conseguir o que querem: lucrar com base na fraude.

Neste outro trecho, a escuridão das vendas propicia o dolo dos comerciantes e as medidas falsas, então, como consequência, eles asseguram para si a escuridão absoluta. $\mathrm{O}$ diabo irritadiço os questiona e sentencia:

Mas ¿quién duda que la oscuridad de sus tiendas les prometía estas tinieblas? Gente es ésta (dijo al cabo muy enojado) que quiso ser como Dios, pues pretendieron ser sin medida; mas Él que todo lo ve les trajo de sus rasos a estos nublados, que los atormentan con rayos (QUEVEDO Y VILLEGAS, 1993, p. 214).

Aqui o jogo se faz baseado em homógrafos e antônimos. Quevedo explora ao máximo a palavra "raso", que segundo o Diccionario de Autoridades, de 1737 , se refere tanto a um tipo de tecido vendido pelos comerciantes quanto ao céu limpo, sem nuvens. Então, nessa passagem, rasos se opõe a nublados (coberto de nuvens), que logo em seguida se atrela à palavra rayos, pois nublado é também uma nuvem que ameaça tormenta (temporal/desordem, agitação). Na comparação dos comerciantes com Deus também há um trocadilho: pois quiseram ser sin medida (grandiosos, infinitos) como Ele, ou seja, através de falsas medidas com as varas de medir.

Nesta outra passagem, em que o fidalgo injuriado toma a palavra e se vangloria da sua linhagem, como se esta lhe protegesse de qualquer condenação, encontra-se o emprego cômico de homógrafos e antônimos referentes a partes do corpo: 
- Pues si mi padre se llamó tal de cual, y soy nieto de tales y cuales, y ha habido en mi linaje trece capitanes valerosísimos, y de parte de mi madre doña Rodriga desciendo de cinco catedráticos, los más doctos del mundo, ¿cómo me puedo haber condenado? y tengo mi ejecutoria y soy libre de todo y no debo pagar pecho. -Pues pagad espalda, -dijo un diablo, y diole cuatro palos en ellas, que le derribó de la cuesta. Y luego le dijo: [...] (QUEVEDO Y VILLEGAS, 1993, p. 216).

O jogo irônico, demolindo o argumento do interlocutor, se faz através dos vocábulos pecho (peito) e espalda (costas). Porém pecho é usado também como "o tributo pago ao rei pelos que não são fidalgos" (Diccionario de Autoridades, de 1737).

No "Infierno", as graças dos cômicos, patifes, trovadores e piadistas são tão frias, e deixam o ambiente tão frio, que os diabos que os vigiam explicam por que: "estão aqui retirados porque se andassem soltos pelo inferno, sua frieza é tanta que atenuaria o calor do fogo" (QUEVEDO Y VILLEGAS, 1993, p. 209) (tradução nossa).

José Montesinos, Dámaso Alonso e Octavio Paz afirmam que Quevedo não teve rival no seu século e nem o tem agora. Para eles, sem dúvida, Quevedo os atrai tanto, por nele existir algo demoníaco: o orgulho (ou o rancor) da inteligência.

Hay que leerlo para saber qué son, realmente, las noches y los días del solitario, el acicate del apetito insaciado, el peso de la sombra de la muerte en la conciencia, las vigilias del rencor, las caídas en la melancolía, el encontrado ir y venir de la cólera al ludibrio y, en fin, toda esa gama de sentimientos y sensaciones que va de la desesperación a la resignación orgullosa. Hecho de contrastes y oposiciones geométricas, violento y simétrico, sentencioso y sarcástico, Quevedo se burla de sí mismo y de los otros [...] (in RICO, 1983, p. 157).

Para Carlos Alberto Loprete (1981, p. 169-170) as cenas são fantásticas e irreais, mas é nesta fantasia que reside a burla; grotescas e caprichosas

9 "están aquí retirados porque si anduvieran por el infierno sueltos, su frialdad es tanta que templara el calor del fuego". 
tornam-se por alguns momentos exorbitantes e sarcásticas. Chegam às vezes ao cinismo e à impiedade, apesar do fundo religioso. Não há nelas nenhum lugar para o amor ou o perdão.

Com a ideia da morte sempre presente, o espetáculo da vida humana atravessa os infernos, com um enorme sarcasmo e uma fúria imaginativa pouco frequentes na literatura. Quevedo traça nos Sueños um quadro satírico da sociedade que não tem estado nem ofício, defeito físico ou moral, ideia ou sentimento, que não estejam representados de maneira grotesca, vivaz e exagerada. 


\section{Bibliografia}

CARPEAUX, Otto Maria. História da Literatura Ocidental. V. II. Rio de Janeiro: O Cruzeiro, 1960.

GARCÍA DE LA CONCHA, Víctor (ed.) e Academia Literaria Renacentista. Homenaje a Quevedo: actas de la II Academia Literaria Renacentista: Universidad de Salamanca, 10, 11 y 12 de diciembre, 1980. $1^{a}$ ed. Reimpressa. Salamanca: Universidad de Salamanca, 1996.

GÓMEZ-QUINTERO, Ela Rosa. Quevedo, hombre y escritor en conflicto con su época. Miami (Flórida): Universal, 1978.

LOPRETE, Carlos Alberto. Literatura española, hispanoamericana y argentina. Buenos Aires: Plus Ultra, 1981.

NOLTING-HAUFF, Ilse. Visión, sátira y agudeza en los "Sueños" de Quevedo. Tradução de Ana Pérez de Linares. Madrid: Gredos, 1974.

QUEVEDO Y VILLEGAS, Francisco de. (edição anotada de James O. Crosby). Sueños y Discursos. Madrid: Castalia, 1993.

RICO, Francisco. Historia y crítica de la literatura española. Siglos de oro: Barroco, V. III, al cuidado de Bruce W. Wardropper [et. al.]. Barcelona: Crítica, 1983.

SCHWARTZ LERNER, Lia. Metáfora y sátira en la obra de Quevedo. Madrid: Taurus, 1983.

\section{Imagens}

Quevedo: Disponível em ttp://2.bp.blogspot.com/_6SsDbu46AJw/ TEOrelXWQwI/AAAAAAAABbE/R5Sv379evkg/s1600/don_francisco_de_ quevedo-villegas.jpg 


\title{
A virulência da flor peçonhenta do desespero: o profano e o demoníaco em Lavoura Arcaica de Raduan Nassar
}

\author{
Raphael Bessa Ferreira $(U E P A)^{1}$
}

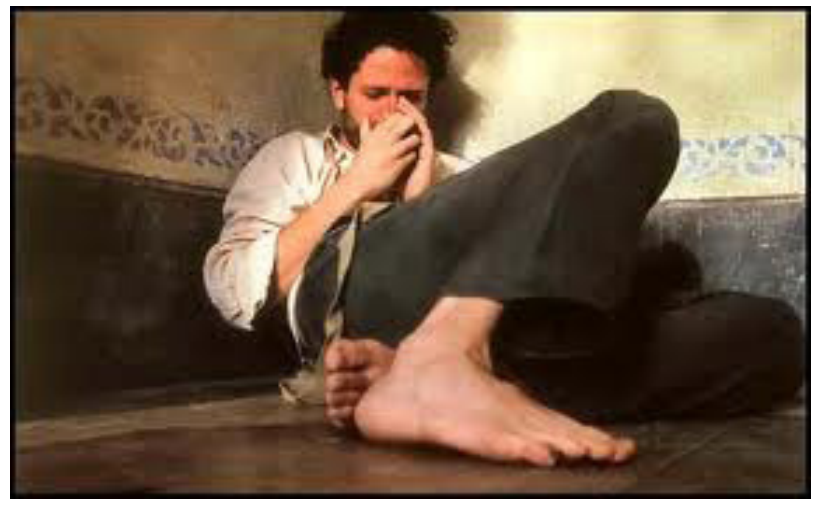

O romance Lavoura Arcaica (1975), do autor paulista Raduan Nassar, prima pelo diálogo conflituoso entre a tradição bíblica-corânica de uma família do interior e o problema do moderno, do novo, da revelia à tradição de vertente patriarcal. A obra é narrada em primeira pessoa pelo narrador-personagem André, que relata os fatos da derrocada familiar de forma não linear, ainda que a ordem ou uma possível linearidade dos fatos possam ser vistas e apreciadas de forma sutil pelo leitor sem esforços maiores.

1 Graduado em Letras pela Universidade da Amazônia - UNAMA. Mestre em Literatura Brasileira pelo Centro de Ensino Superior de Juiz de Fora - CES/JF. Professor Efetivo da Cátedra de Literatura da Universidade do Estado do Pará - UEPA. Coordenador Adjunto do Curso de Letras da UEPA. Endereço eletrônico: ru-98@hotmail.com 
Contudo, o que ainda chama atenção no livro é a sua grande carga estilística dada ao leitor pela linguagem: altamente lírica e simbólica, além de apresentar um deslocamento temporal dos fatos lembrados e narrados, fatos que enlevam à obra como uma narrativa densa, cheia de estilhaços e fragmentos nos quais o leitor se perde tal qual num labirinto.

Raduan Nassar emprega em seu romance um meticuloso engenho de ourives. O autor almeja a perfeição por meio da peculiar escolha de vocábulos, do uso dos tempos verbais, da seleção de metáforas e do cuidado com a sonoridade em alguns casos. Latente é o encadeamento das frases em períodos ora longos, ora curtos, juntos em um torrencial paragráfico capitular.

Misto de monólogo com fluxo de consciência, o narrador André ainda deixa momentos de diálogos que remetem às antigas tragédias gregas e à ação rápida e desconcertante de ritmo épico. O narrar elíptico é associado ao viver epiléptico de nosso narrador-personagem. Uma verdadeira verborragia ou um parto abortivo de dores, mágoas e tristezas que insistem na mente de André.

À primeira vista, o leitor pensa, com efeito, que está diante de uma obra barroca, devido à carga de conflito entre o racional-espiritual e o carnal-profano. O romance convida ainda à reflexão do contato com as tragédias grego-romanas, haja vista a enorme carga de tensão presente na narrativa nassariana.

O romance se divide em duas partes, sendo a primeira chamada de "A partida" e a segunda de "O retorno". Na trama, André, o protagonista e narrador do livro, é um jovem que ambiciona a sua liberdade devido ao modus operandi no qual trabalha e vive com sua família: em um meio rural antigo, arcaico e que faz lembrar um passado tradicionalista: patriarcal.

Compondo-se de oito membros, a família de imigrantes libaneses tem Iohána como o patriarca, a mãe afetuosa, Pedro (o filho mais velho), André (o narrador), Ana (desejo incestuoso de André), Lula (o caçula), Rosa (filha mais velha), Zuleika e Huda. Como membro memorial temse o falecido e inominável avô árabe, para quem ainda reservam, por tradição, um lugar à mesa. A figura do avô, tanto quanto a personagem do pai, representam na obra o grande motif da narrativa: o tempo. 
Para exemplificar, a intertextualidade com o livro bíblico do Eclesiastes, de cuja fonte Lavoura Arcaica também bebe, aponta o empenho do homem medido ao esforço do tempo: "Há tempo de nascer, e tempo de morrer, tempo de plantar, e tempo de arrancar o que se plantou” (BÍBLIA SAGRADA, 1997, p.869).

Dessa forma, Lavoura Arcaica se apresenta com um hibridismo temporal no qual explícita e implicitamente o tempo será o grande tema no livro, fazendo com que a linha divisória entre os dois seja muito bem marcada, uma vez que uma mistura de reminiscências do período da infância se aglutinará com o período da adolescência em casa e com o período da adolescência fora de casa.

O que se tem, então, nada mais é do que uma narrativa fragmentária, onde o narrador, ardilosamente, irá compor um mosaico misto de expressionismo memorialístico com uma poética do tempo e da memória com o intuito de ludibriar pelo seu próprio discurso, ora deixando ciente alguns fatos, ora omitindo perspicazmente outros fatos.

Ao abandonar sua família para ir morar em uma pequena cidade (fuga do campo para a cidade, do interior para o centro), André foge também de um mundo asfixiante, opressor, repressor, dominador da lavoura, onde o passar do tempo parecia consumir as gerações com as proibições e interdições paternas,no qual a rigidez moral mantinha as estruturas sociais análogas às tradições das famílias árabes (no caso da narrativa, a família é descendente de libaneses).

O mundo familiar em que André vivia era o mundo em que a loucura das paixões primitivas consumia sua alma, o inquietava e o atormentava, exemplo é o relacionamento incestuoso com sua irmã, Ana. O mote da narrativa se baseará nisto: na quebra deste tabu como quebra dos paradigmas sociais, familiares e quaisquer estruturas ou instituições de ordem social.

Não é por acaso que se pode fazer uma união de motifs entre André e outros dois personagens incestuosos das tragédias: Édipo e Calígula. Enquanto que o primeiro "é inocente, porque vítima da fatalidade; o segundo, um sonhador (além de seu amor por sua irmã, ele queria possuir a Lua)" (ALABDOU, 2001, p.59) 
Contudo, cumpre destacar que essa quebra do tabu por parte dos irmãos Ana e André se faz devido a um anseio por

descobrir a sacralidade da natureza. A importância da nudez cerimonial e das relações sexuais rituais não deve ser interpretada simplesmente como manifestações libidinosas. A revolução sexual recente tornou obsoletos tais tipos de hipocrisia e farsa. Em vez disso, a nudez ritual e as práticas orgiásticas buscam recapturar o valor sacramental da sexualidade. Pode-se falar da nostalgia inconsciente por uma existência fabulosa, paradisíaca, livre de inibições e tabus (ELIADE, 2001, p.66)

Com sua fuga, André destrói a harmonia da família. Família em que a voz paterna se faz presente como a voz de um Deus, na qual os demais membros devem segui-la, tornando assim o regime um misto de familiar com religioso.

$\mathrm{Na}$ trama de Lavoura Arcaica, observamos o personagem-narrador André divergir das palavras do pai, vistas como moralizantes e verdadeiras. Esta rebeldia às palavras paternas nada mais é do que um processo de fuga das amarras e das normas impostas. É quando foge de casa para viver em um novo lugar que André pode viver em mundo próprio, somente seu e de mais ninguém, é o mundo profano, que nas palavras do personagem é o "quarto catedral" (NASSAR, 2005). Catedral religiosa e símbolo do profano, espaço sagrado de André, que promove a inversão de valores patriarcais:

Se para o homem arcaico a vida no mundo tem um valor religioso, isso resulta de uma experiência específica do que se pode chamar "espaço sagrado". De fato, para o homem religioso, o espaço não é homogêneo, algumas partes dele são qualitativamente diferentes. Há um espaço sagrado e daí, forte e significante; e há outros espaços que não são sagrados e, conseqüentemente, são sem estrutura, forma e significado. Isso não é tudo. Para o homem religioso, essa heterogeneidade espacial se expressa na experiência de uma oposição entre espaço sagrado — o único real e realmente existente — e todos 
os outros espaços, expansão amorfa circundando o sagrado. A experiência religiosa da heterogeneidade do espaço é uma experiência primordial, comparável à descoberta do mundo. Isso porque é essa divisão espacial que permite a constituição do mundo, uma vez que revela o ponto fixo, o eixo central para toda orientação futura. Quando o sagrado se manifesta em qualquer hierofania, há não apenas uma ruptura na homogeneidade do espaço; há também a revelação de uma realidade absoluta, oposta à irrealidade do vasto espaço circundante. A manifestação do sagrado cria o mundo ontologicamente. $\mathrm{Na}$ expansão homogênea e infinita, na qual é impossível haver um ponto de referência, de onde se possa estabelecer alguma orientação, a hierofania revela um ponto fixo absoluto, um centro (ELIADE, 1979, p.26-27)

Logo na página inicial da trama, vê-se uma descrição do quarto de pensão onde André está refugiado: "Os olhos no teto, a nudez dentro do quarto; róseo, azul ou violáceo, o quarto é inviolável; o quarto é individual, é um mundo, quarto catedral” (NASSAR, 2005, p. 7). Em sua descrição, pode-se ver que o quarto, não o de seu lar familiar, mas sim o de uma pensão (fora de casa), passa a ser para André um lugar de refúgio do mundo patriarcal de sua família, torna-se não apenas uma moradia bem como uma "catedral", um "mundo" que é "individual". Tem-se então, a imagem de um mundo solitário (de André) em que este é o templo, a catedral erguida pelo personagem, a fim de criar seu lugar-no-mundo, sua religião: "fundarei minha igreja particular, a igreja para o meu uso, a igreja que frequentarei de pés descalços e o corpo desnudo, despido como vim ao mundo"; e mais à frente, "me senti num momento profeta de minha própria história” (NASSAR, 2005, p. 88).

Essa criação de um templo e de uma religião não é à toa, pois André, devido à criação ora opressora do pai ora amorosa da mãe, acaba por tornar-se um ser solitário que busca um refúgio da conturbada vida familiar. Daí o personagem querer afastar-se de casa, principalmente por causa do pai (opressão), da mãe (muito carinho) e da irmã (incesto). 
O quarto (sagrado) da pensão nada mais é do que a caverna primordial, o buraco-útero-refúgio no qual André pode contemplar o retorno a um tempo inicial e primordial do mundo primitivo e arcaico, o universo sagrado em que os seres mitológicos e deuses religiosos criaram-se. É o caos inicial que engendrará o mundo tal qual se conhece.

A sensibilidade captada dentro da própria solidão agora pode, no quarto-catedral, ser expressa no momento último e apoteótico da consagração do espaço, "onde, nos intervalos da angústia, se colhe, de um áspero caule, na palma da mão, a rosa branca do desespero, pois entre os objetos que o quarto consagra estão primeiro os objetos do corpo" (NASSAR, 2005, p.7). O rito sexual (onanismo) literalmente "batiza" e "abençoa" André em sua nova religião: a profanação do sagrado por meio da sexualidade e da revolta aos preceitos morais, revelando o caráter simbólico do ato sexual em local sagrado; santificar o ato genitor, o ato da criação, pois André cria por meio de sua semente (líquido espermático e fecundo) a sua religião. O sagrado é e torna-se profano. Como no grande evento do "adeus à carne" (carnivale), onde o corpo se desprenderá em partes, em risos na alegria, haverá uma ordem que conviverá com a desordem, seria a ordem de Deus (pai, Iohána) que é desordenada, às vezes, com a desordem filial (os homens destituídos do Paraíso, André) que em algumas ocasiões traveste-se de ordem.

André é um personagem que busca a desordem diabólica e profana pela linguagem, em contraposto ao palavreado arcaico e sermonístico do pai. Dessa forma, o narrador-personagem precisa criar uma nova forma de linguagem e, consequentemente, a sua palavra sagrada. Ele a cria na profanação do sagrado, já em casa e diante do pai, onde usa sua nova arma para combater o inimigo. Engana e ludibria o pai. Mais tarde, no desfecho trágico da narrativa, André apenas observa o pai cair em suas próprias armadilhas, no próprio jogo de palavras por ele criado e expressado, mas naquele momento não utilizado.

O personagem de André converte-se em típico exemplo de possesso e/ou endemoniado, característico, inclusive, das personagens de Dostoiévski: "Há momentos intensos de medo, por exemplo, em que um homem de repente grita feito um possesso, e com uma voz que nem sequer se poderia supor que tivesse antes". (DOSTOIEVSKI, 2004 p.587). Embebido pelo vinho inebriante a personagem nassariana jorra 
toda a peçonha desesperadamente à própria família: "Você tem um irmão epilético, fique sabendo" (NASSAR, 2005, p.39); "Nosso irmão é um epilético, um convulso, um possesso" (2005, p.40); "Traz o demônio no corpo" (2005, p.40).

A fala e o discurso de André podem parecer jorrar de forma aleatória, e é isso que o personagem quer. Não há mais regras a serem cumpridas e observadas. Contudo, o pai quer fazer ver ao filho o erro cometido: "Não receba com suspeita e leviandade as palavras que te dirijo, você sabe muito bem que conta nesta casa com nosso amor!" (NASSAR, 2005, p.166).

A fúria e o ímpeto de André, o gauche, endemoniado, aquele que pertence ao lado esquerdo, à posição que é contrária a Deus (como na doutrina cristã, onde os que serão salvos ficarão sentados à direita de Deus). André, Ana, Lula e a mãe sentam-se à esquerda do pai, posição do errôneo, do canhestro, do sinistro e do malévolo na tradição cristã. Os ataques possessos do personagem são causados pela sua cólera incandescente ao mando violento e abusivo do pai opressor ao mesmo tempo em que são derivados da não aceitação amorosa de sua irmã, Ana. A tempestuosidade do narrador-personagem alia-se não só às feridas paternas, mas também às feridas passionais.

Com tudo isso uma possível ruptura na tradição familiar se faz presente e o pai já a pressente. Iohána intenta cessar com o jorro verborrágico e incontrolável do filho, mas de nada adianta: "Quero te entender, meu filho, mas já não entendo nada" (NASSAR, 2005, p.163).

O intento paterno para restabelecer a ordem em casa e no discurso desanda: "Já basta de extravagâncias, não prossiga mais neste caminho, não se aproveitam teus discernimentos, existe anarquia no teu pensamento, ponha um ponto na tua arrogância, seja simples no uso da palavra!" (NASSAR, 2005, p.166). Uma verdadeira arena onde a linguagem filial desafia a linguagem patriarcal.

O homem é livre e liberto pelo espírito dionisíaco da vida, a força contrária, a opressão, é conflito contínuo de expansão e diminuição da vontade libertária. O processo demoníaco e profano de André se faz presente devido ao poder dominador de seu genitor. 
Ampliando os limites da obra de arte literária, Raduan Nassar amplifica as reflexões concernentes aos trâmites universalistas. Lavoura Arcaica não se deixa subordinar ao mero relato literário, mas estende-se ao fenômeno reflexivo que engloba a linguagem, a cultura, a sociedade e a história. Como nas palavras (des)encantadas de André: "Estranho é o mundo, pai, que só se une se desunindo" (NASSAR, 2005, p.75).

$\mathrm{Na}$ tessitura de um poema em prosa, ou de poesia em prosa, Nassar mescla o lírico com o trágico (filosofia do trágico) e lança uma tragédia (poética do trágico) moderna baseado em pressupostos ancestrais. $\mathrm{Na}$ escolha meticulosa das palavras proferidas pelo filho desgarrado André, narrador que torna-se um sábio da arte poética, um espadachim da retórica, como o seu pai, o autor trabalha arduamente com as palavras, os vocábulos e suas colocações nas estruturas frasais.

A leitura feita aqui permite crer que Lavoura Arcaica se vale do discurso opressor paterno para discutir acerca da liberdade, mas, destoando das leituras aos moldes históricos, vê-se que tal liberdade se alia a uma afirmação da vida (Nietzsche) e que, para que se possa afirmar uma liberdade à vida humana, há de se confrontar com o incógnito, com a Natureza, com o destino, daí o sentido trágico que o romance possui e demoníaco do personagem principal, André, o coxo, o esquerdo, o possesso, o epilético. 


\section{Bibliografia}

ALABDOU, Leonard Mouti. Palavra e Veneno. Revista Bravo. São Paulo: Abril. N.49. Outubro de 2001. p.59.

BÍBLIA SAGRADA: Edição Pastoral. São Paulo: Paulus, 1997.

DOSTOIEVSKI, Fiódor. Os Demônios. São Paulo: Ed.34, 2004.

ELIADE, Mircea. Ocultismo, bruxaria e correntes culturais: ensaios em religiões comparadas. Belo Horizonte: Interlivros, 1979.

. O sagrado e o profano. São Paulo: Martins Fontes, 2001.

NASSAR, Raduan. Lavoura Arcaica. São Paulo: Companhia das Letras, 2005.

\section{Imagem:}

Disponível em http://t1.gstatic.com/images?q=tbn:ANd9GcSd6tQ5r-rrVYFl-9vcK3C3aU3TV9dAUqvNAlxKOC2eRKe3EMBM2w, 07/10/2012 



\title{
Baudelaire e Belzebu
}

\author{
Larissa Drigo Agostinho (Paris IV-Sorbonne) $)^{1}$
}

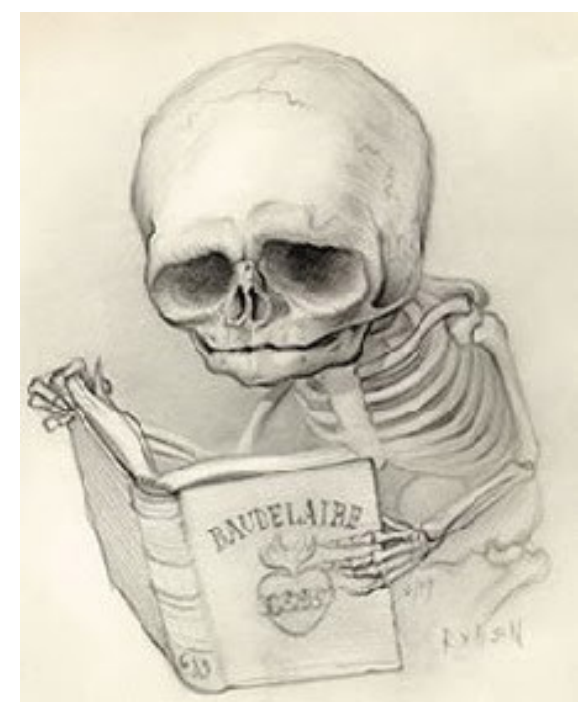

Propomos neste artigo discutir o significado do satanismo de Baudelaire com relação ao seu tempo e a poesia do primeiro romantismo francês. Isto significa discutir o significado do satanismo de Baudelaire com relação ao imaginário católico do primeiro romantismo.

A primeira geração de poetas românticos franceses, Victor Hugo, Lamartine e Vigny será fortemente marcada pelo terror revolucionário que provocou no começo do século XIX um retorno das forças

1 Larissa Drigo Agostinho, mestre em filosofia pela Universidade de Paris I-PanthéonSorbonne e mestre e doutoranda em literatura francesa pela Universidade de Paris IV-Sorbonne é professora convidada do mestrado lato sensu Psicanálise e linguagem: Uma outra Psicopatologia na Pontifícia Universidade Católica de São Paulo. E-mail: larissadrigo@yahoo.com.br. 
conservadoras que pretendiam negar todos os ideais do século XVIII. Trata-se de um movimento estético, moral e político a que se chamou contrarrevolução. O poeta romântico, desta primeira geração, é aquele que procura um retorno ao antigo regime e a reinstauração do catolicismo. Uma geração que Paul Bénichou definiu a partir do termo "sacre de l'écrivain":

Por mais difícil que seja definir através de caracteres constantes a visão romântica do mundo, percebemos que uma certa modificação na fé humanista do século precedente forneceu o essencial, e que no seio desta modificação, mesmo que ela se apresentasse como um compromisso com a fé religiosa, continuava a se desenhar os contornos de um poder espiritual novo. Este poder, residia na literatura, elevada a uma dignidade até então desconhecida. O espiritualismo romântico se inclina na direção de um investimento particular na poesia, neste sentido o romantismo é uma sacralização do poeta. (...) É na exaltação da poesia, colocada na altura do valor mais elevado, que se tornou religião, luz do nosso destino, que devemos ver o traço distintivo do romantismo. ${ }^{2}$ (BENICHOU, 2004, p. 259)

O poeta do primeiro romantismo é o poeta mago, profeta, aquela que fala ao povo em nome de Deus, como guardião de seu destino terrestre e ponte entre o divino e o humano. O poeta é investido de um poder "extraordinário", uma vez que se faz porta-voz dos costumes e tradições nacionais e religiosas, ele é capaz de unificar a nação em torno de uma crença, em torno de um único Deus, como um rei simboliza o poder divino, encarna-o na terra e assim reúne a totalidade do seu reino em torno de sua figura.

"Do Consulado à Restauração, um longo movimento do pensamento conservador exalta a poesia para torná-la o esteio da religão, a reparadora salutar da subversão filosófica" (BENICHOU, 2004, p 131) Por subversão filosófica entenda-se o racionalismo do século XVIII, sua crítica à dogmática religiosa, enfim todo movimento de ideias que transformou o pensamento das Luzes em agente da revolução. Portanto, nos anos 20 do sécul XIX, os jovens românticos, católicos e monarquistas fundam sua poesia na referência religiosa que o movimento da

2 As traduções são da autora. 
contra-revolução exaltava como único meio para restaurar os costumes e tradições banidos da França pela revolução. O romantismo tem sua origem no movimento contrarevolucionário posterior à 1789: "é do seio da contra-revolução que emergiu entre 1800 e 1820 a fonte poética do século XIX. A ideia de um ministério espiritual do poeta, que é a alma da poesia moderna, germinou neste meio; os poetas saíram primeiramente, de lá” (BENICHOU, 2004, p.186.)

É desta poesia que Baudelaire extrai o material de sua lírica, do romantismo católico e conservador que transformou a religião na fonte que garantiu legitimidade aos governos restauradores.

\section{Deus, o diabo e as mulheres}

É justamente nos poemas de temática "amorosa" que Baudelaire destila todo seu veneno contra os ideais românticos. Observemos, por exemplo, o poema "Je t'adore à l'égal de la voûte nocturne" (XXIV), ("Eu te amo como se ama a abóbada noturna").

Eu te amo como se ama a abóbada noturna,

Ó taça de tristeza, ó grande taciturna,

E mais ainda te adoro quanto mais te ausentas

E quanto mais pareces, no ermo que ornamentas,

Multiplicar irônica as celestes léguas

Que me separam das imensidões sem tréguas. ${ }^{3}$ (BAUDELAIRE, 1985, p. 161)

A evocação da mulher amada adorada contrasta com os adjetivos empregados pelo poeta para descrevê-la. O eu lírico compara sua amada a um "vaso", poderia ele ter sido mais cruel e irônico? A mulher é aqui reduzida ao estatuto de um objeto de decoração. Em seguida, ele a qualifica de "grande taciturna". Uma mulher triste, portanto, como uma espécie de zumbi, uma morta-viva, que aparece sempre à noite, para "ornamentar" o poema.

3 "Je t'adore à l'égal de la voûte nocturne,/ Ô vase de tristesse, ô grande taciturne,/ Et t'aime d'autant plus, belle que tu me fuis, / Et que tu me parais, ornement de mes nuits, / Plus ironiquement accumuler les lieues/ Qui séparent mes bras des immensités bleues." BAUDELAIRE, 1999, p. 73) 
Como constatamos nos últimos versos da estrofe citada, o poeta se pergunta se "não é irônico que seu amor aumente com a distância que o separa de sua amada"? Não é irônico que o eu se sinta cada vez mais apaixonado à medida que se sente cada vez mais distante de seu ideal, cada vez mais incapaz de ter em seus braços as "imensidades azuis "? Eis que a mulher adquire seu estatuto ideal, ironicamente distante, e idealizada, ela é inacessível, comparada com o "azur", ou "Ideal”. Assim quando ela finalmente ocupa o lugar que é o seu no imaginário romântico, não sem ironia, pois ao se indagar sobre este ideal, Baudelaire já procura indicar a sua nulidade, eis que ocorre o seu rebaixamento, e se produz o ataque certeiro dos versos/vermes baudelairianos:

Ao assalto me lanço e agito-me na liça,

Como um coro de vermes junto a uma carniça,

E adoro, ó fera desumana e pertinaz,

Até essaalgidezquemaisbelatefaz! ${ }^{4}$ BAUDELAIRE, 1985, p. 161)

O eu lírico avança na direção da mulher sempre distante, e a ataca. Este ataque é dirigido a mulher ideal, comparada as "imensidões azuis" que se torna agora uma "besta" ,um animal, uma "presa". O poeta é comparado a um "coro de vermes" que profana um cadáver, o corpo inerte da mulher idealizada e "querida" por poetas românticos de várias gerações.

Para Vaillant (2007, p. 121) o alvo de Baudelaire seria a frigidez feminina, "Devemos sem duvida entender que a mulher (...) cria a ilusão pela sua ironia de estar a quilômetros de distância de seu parceiro: a ironia qualifica o efeito de distanciamento - portanto, de centralização - induzido pela indiferença" A ironia seria assim, aquela da mulher que frigida se distancia do poeta, é indiferente à ele e ao seu desejo.

Mas poderíamos ir muito mais longe nesta interpretação. Devemos nos perguntar: Contra quem Baudelaire dirige sua ironia? Quem é esta mulher fria e ideal? A ironia em questão não é a da mulher frigida, mas sim aquela que faz com que o amor do poeta aumente com a distância

4 "Je m'avance à l'attaque, et je grimpe aux assauts,/ Comme après un cadavre un chœur des vermisseaux,/ Et je chéris, ô bête implacable et cruelle !/ Jusqu'à cette froideur par où tu m'es plus belle !" (BAUDELAIRE, 1999, p. 73) 
que o separa de seu objeto de desejo. Como se Baudelaire se perguntasse, "não é irônico, e cômico, tantos poetas cantando amores impossíveis, cantando amores que existem apenas em sua imaginação, amores ideais, idealizados, justamente pela distância que separa os amantes"? Esta frieza é na verdade, não a de uma mulher irônica ou frigida, mas a de uma mulher morta, de um ideal feminino romântico que Baudelaire transforma num cadáver em putrefação, que ele ataca como um verme com seus versos.

Esta mulher que para o crítico Vaillant é a mulher-frigida é na verdade a mulher idealizada pelo primeiro romantismo que é identificada com a própria Virgem Maria. Tomemos, por exemplo, o poema de Victor Hugo (1972, p. 166) «À toi » presente na antologia Odes et ballades de 1822, portanto, do primeiro livro do autor, marcado pelo imaginário católico, e pelo conservadorismo político, do jovem e monarquista Victor Hugo.

Este poema foi escrito em comemoração a festa da Virgem, "le jour sacré parmi les jours !’. O eu lírico relembra sua infância, que em Victor Hugo, rima com inocência, ignorância e esperança, onde o eu via apenas a virgem no céu, "belle et pure", aquela que deveria como ele compartilhar uma felicidade sem fim ("partager un bonheur qui ne doit pas finir"). Mas este tempo passou. Hoje "o mal se eleva" ("le malheur s'est levé"). O poeta "órfão", "sem os prantos de sua bem amada" ("sans les pleurs de sa bien-aimé") segue sozinho, uma "lâmpada apagada entre os vivos" (il est chez le vivants comme une lampe éteinte”).

Notamos que a Virgem "bela e pura” é também a bem amada do poeta, ela é também a sua mãe que adquire cada vez mais traços humanos ao longo do poema. O eu clama para que a Virgem embeleze sua vida com seu sorriso, pois "A maior felicidade ainda está no amor" ("Le plus grand bonheur est encore dans l'amour") e a convida a experimentar com o poeta "um casto casamento" ("chaste hymen"). Finalmente, ele pede que ela venha para seus braços sem temor, pois "teu esposo não quer que sua glória/ prejudique sua felicidade" ("ton époux ne veut pas que sa gloire / Retentisse dans son bonheur "). O poema termina com o eu se dirigindo à mulher amada/ a Virgem e declarando que, se arrependerá " gemendo", "aquele que morreu sem reclamar,/”E que te amava com tanto amor!" ("gémissant à son tour", "celui qui mourut sans se plaindre, / Et qui t'aimait de tant d'amour !’). 
Aqui observamos que a mulher fetiche dos românticos é ainda mais adorada quanto mais se assemelha a Virgem Maria, quanto mais distante, portanto, está do poeta, que vê o seu amor ainda aumentado pela possibilidade de uma união casta e pura com essa mulher idealizada. Esta ideal de amor e de mulher, construído a partir do imaginário católico será explorado por Baudelaire em todos seus contornos e desdobramentos. Esta mulher casta será identificada com uma "taciturna", um "vaso de tristeza", enfim uma morta - um cadáver - que o poeta ataca e devora como um verme, com o único intuito de ironizar, desmascarar e rir de uma poética católica que negava a vida e seus prazeres materiais em nome da salvação extraterrena, da felicidade casta, a "voluptuosidade santa" do paraíso celestial.

Constatamos que a trajetória irônica do poema "Je t'adore à l'égal de la voûte nocturne" onde a mulher é idealizada e em seguida rebaixada ao estatuto de cadáver se torna cada mais evidente quando comparamos à poesia de Baudelaire à de Victor Hugo, por exemplo. Isto deixa claro que o alvo da ironia baudelairiana era justamente a poesia do primeiro romantismo. Como se esta mulher fria, fosse não somente o indício da impossibilidade de se alçar este ideal de amor puro, esta mulher que na verdade é um cadáver, simboliza aqui a morte do ideal romântico. Ao transformar um ideal de amor num corpo inerte e em decomposição Baudelaire ataca estes ideais, procura mostrar que o que está verdadeiramente em estado de putrefação neste momento da história são os ideais românticos de pureza, castidade, os ideias católicos que asseguram a manutenção de um imperador que usurpou o poder que lhe foi concedido "democraticamente".

Assim ao rebaixar este ideal romântico é todo o imaginário do romantismo que Baudelaire procura ironizar. A mulher pálida e casta só poderia ser um cadáver, pois todo o amor que não se materializa simplesmente não existe. A negação da realização amorosa, a insistência romântica em manter o amor sempre casto ou impossível, contribui certamente para a afirmação do amor, como um ideal que não encontra lugar sobre a terra, mas para Baudelaire essa negação da vida, este ascetismo católico não passa de uma abstração vã, fora de moda, de uma ideologia em ruínas, que insiste em se perpetuar. Baudelaire quer deixar em evidência o estado de ruínas no qual se encontra o imaginário romântico, que seria absolutamente incapaz de dar conta da experiência dos sujeitos na modernidade. 


\section{Mas afinal, porque o diabo?}

Julles Vallès, crítico literário e jornalista do século XIX, contemporâneo de Baudelaire, escreve, no momento da morte do poeta, no jornal La rue uma dura crítica ao poeta seu contemporâneo, o crítico afirma o seguinte:

Havia nele algo de padre, de velha dama, e do ator. Era sobretudo um ator, mal ator. (...)

Satã, este diabinho, fora de moda, acabado, que ele se colocou como objetivo de cantar, adorar e abençoar! Por quê? Por que o diabo ao invés do bom Deus? É que, vejam vocês, este palhaço da imortalidade, era no fundo um religioso ; não um cético ; ele não era um demolidor, mas um crente ; ele era o niam-niam de um misticismo besta e triste, no qual os anjos tem asas de morcego e rostos de meninas; eis o que ele inventou para nos chocar, este Jeune France velho demais, esta criança livre pensadora. (VALLES, In : BAUDELAIRE, 1975, p. 971-973, negrito nosso)

Esta crítica é muito importante, uam vez que além de nos revelar que o satanismo, em meados da metade do século XIX não tinha nada de chocante, pelo contrário não passava de um lugar-comum desgastado da poesia francesa, nos mostra também que a pior acusação que poderia ser feita a um poeta neste período era justamente compará-lo aos poetas católicos do começo do século. Por que o crítico para desqualificar a poesia baudelairiana atribui a ela total ausência de originalidade devido ao seu caráter "religioso".

O texto já nos fornece um caminho interpretativo, antes de mais nada, o recurso ao satanismo não tinha como intuito o choque, assim ele deixa evidente que a agressividade da poesia baudelairiana não era gratuita, e isso nos coloca diante da questão de saber por que, mesmo sabendo que o satanismo já estava fora de moda em seu tempo, Baudelaire decide, apesar deste fato, utilizar esta temática em sua poesia. Devemos nos perguntar que função teria esse recurso que longe de chocar seus contemporâneos os deixaria na verdade entediados ao ter diante dos olhos nada além de um desgastado clichê? 
Em seu Baudelaire Sartre afirma que Baudelaire faz o Mal de maneira consciente, e justamente por ter consciência do mal que ele praticava, afirma na verdade, sua adesão ao Bem. Para Sartre ao querer fazer o contrário do Bem, Baudelaire afirma e conserva a ordem que ele pretende negar. Assim a moral baudelairiana parece ser o último recurso racional que procura evitar a confrontação com a verdadeira natureza, fictícia da moral. O hipócrita seria assim um homem satânico, um pecador, aquele que faz o contrário do Bem, conscientemente e que sente um verdadeiro prazer na culpa, no remorso, na martirização na qual a ação maldosa the engaja.

Mas o que Baudelaire procura ao ironizar os ideais românticos, é evidenciar a falência moral de seu tempo expondo suas contradições, demonstrando o caráter hipócrita desta moral que mesmo ao fazer o mal afirma o bem supremo, clama por redenção, nega a vida e se mantém pregando ideais absurdos. A ironia, esta que permite ultrapassar a dicotomia entre o bem e o mal só é possível a partir da reivindicação de autonomia da poesia que se faz justamente a partir de sua desobrigação com relação a moral:

"Eu digo que se um poeta persegue um objetivo moral, ele diminuiria a força de sua poesia, não é imprudente apostar que sua obra será ruim. A poesia não pode, sob pena de morte, se assimilar à ciência ou a moral; ela não tem a verdade por objeto, ele só tem a si mesma" (BAUDELAIRE, 1976, p. 628, negrito nosso)

Esta independência da arte com relação a moral nos permite justamente pensar a moral, como Nietzsche também pretendia, como uma mentira, uma ficção. No Salão de 1859, capítulo cinco, intitulado, "Religião, historia, fantasia" Baudelaire anuncia como devemos compreender a moral presente numa obra de arte: "Digamos, portanto simplesmente que a religião, sendo a mais elevada forma de ficção do espírito humano (eu falo propositadamente como falaria um professor ateu de belas artes, e nada deve ser concluído contra a minha fé)." (BAUDELAIRE, 1976, 628, negrito nosso) Em seguida, ele explica que o poeta, um comediante, um artista "acreditam na realidade do que representam, porque são acalentados pela necessidade", por isso a arte é o único domínio onde o homem pode dizer " eu acredito se quiser, se eu não quiser, eu não acreditarei”. (BAUDELAIRE, 1976, 629) 
Um hipócrita, dissimula, mente, age contrariamente aos princípios e ideias dos quais fala. E o que faz um poeta? Não é esta, a arte mesma de escrever: mentir? Dissimular? Tornar-se outro ?

Não é assim que Fernando Pessoa define o poeta, como um fingidor ? Um fingidor que finge tão bem que chega a fingir que é dor a dor que deveras sente? Como quem diz que a verdadeira arte da poesia consiste em criar uma mentira convincente.

Mas Baudelaire não quer convencer e por isso confessa sua hipocrisia, a ironia de sua arte está no desejo de expô-la justamente como uma mentira, uma dissimulação, ele não quer convencer não quer esconder nada, quer expor a mentira que sustenta a sua arte, quer expor a verdade do material a partir do qual ele cria, que é a temática do primeiro romantismo francês.

A ironia de Baudelaire que é a mentira desvelada, a arte que se assume enquanto mera aparência exprime e desvela a contradição entre a ação e o enunciado, entre o imaginário romântico e o baudelairiano onde o primeiro aparece em estado de putrefação. A ironia abre uma fissura entre o real e o ideal, entre o conjunto das ideias românticas a realidade cotidiana, que o poeta assim como seus leitores hipócritas conhecem bem. A ironia denuncia a distância entre o ideal e o real, e instaura uma desconfiança com relação a esses ideais, que parecem ironicamente cada vez mais puros quando comparados à imundice e miséria do mundo prostituído no qual o poeta parece diabolicamente mergulhado. O que Baudelaire quer não é simplesmente chocar seus leitores, mas levá-los a desconfiar de um imaginário literário que os faz viver inexoravelmente na mentira.

Por isso Baudelaire recorre ao cômico. O próprio Baudelaire nos deixou um tratado sobre a essência do riso, um artigo que atesta a importância da questão em sua obra, uma questão e o poeta confessa ter se tornado "uma obsessão". Ele tem como título "De l'essence du rire et généralement du comique dans les arts plastiques".

Neste texto Baudelaire define o riso a partir de sua dimensão diabólica como contrário às disposições dos sábios, (o sábio ri tremendo) entenda-se aqui, por exemplo, Virginie, o sábio, a moça casta, ele é aquele que é incapaz de rir, que nos mostra a força demolidora do riso. 
Rir da moral, rir dos costumes e de um sistema de valores é muito mais do que simplesmente criticá-los.

O riso é próprio dos espíritos superiores, ele implica uma certa superioridade do homem que ri em relação ao que provoca o seu riso. Por isso o riso demonstra a insignificância do que nos faz rir, ele denigre, rebaixa, desqualifica. Mas o riso é também o resultado da própria insignificância humana. Ele se situa entre estes dois extremos, por isso ele é também diabólico, porque o riso é essencialmente humano, ele se situa entre a grandeza divina e a baixeza animal. Esta oscilação é que nos faz rir, rimos das nossas pretensões de grandeza assim como da nossa mediocridade.

Rindo Baudelaire não apenas instaura uma desconfiança com relação ao sistema de valores de seu tempo, expondo suas contradições, ele pode, através do riso dissolvê-las, rindo da sua incoerência é todo o edifício moral que se abala, que desvela sua hipocrisia, que se mostra como uma mentira, mera aparência.

Ao rir de seu tempo, dos costumes e da moral cristã que limitava a experiência poética moderna, Baudelaire indica um novo horizonte para o qual a poesia deveria se abrir. Nela o romantismo aparece como um clichê degradado, risível, rebaixado, exposto em toda a sua insignificância.

Com Baudelaire a poesia se desprende das antigas formas de expressão da subjetividade e da gramática religiosa dos afetos, (que mantém as relações amorosas enclausuradas pelas oposições entre amor/sexo, corpo/ alma, ideal/ spleen, pecado/redenção etc.) ela se desprende do jogo de poder entre submissão e dominação, se libera de toda obrigação moral (se desliga do Bem como do Mal, de Deus como de Satã). Um passo decisivo na configuração da arte autônoma, aquela que não pretende ensinar, educar ou oferecer redenção, mas ser o veículo de expressão e renovação do próprio presente, oferecer aos seus leitores uma arte na qual eles possam não apenas se identificar, mas ir além de si mesmos.

A partir deste momento, uma outra modernidade poderá surgir, a que Baudelaire anuncia em seu Peintre de la vie moderne, este momento em que a arte autônoma, liberada de toda e qualquer obrigação moral, se dedicaria a extrair o que há de eterno e imutável no fugídio e fugaz presente. 


\section{Bibliografia}

BAUDELAIRE. CEuvres complètes II. Paris : Gallimard, 1976.

Les fleurs du mal. Paris : LGF, 1999.

As Flores do mal. Trad : Ivan Junqueira, Rio de Janeiro:

Nova Fronteira, 1985.

HUGO, V. Poésie. Paris : Seuil, 1972.

SARTRE, J-P. Baudelaire. Paris: Gallimard, 1975.

VAILLANT, A. Baudelaire, poète comique. Rennes: Presses universitaires de Rennes, 2007.

VALLES, J. «Charles Baudelaire », La rue, 7 septembre 1867, In :

Baudelaire, Guvres, R. Bellet ed., t. I, Paris : Gallimard, "Bibliothèque de la Pléiade ", 1975.

\section{Imagem:}

Disponível em http://1.bp.blogspot.com/-Qpuvx1oDQVA/Tl2W70Ny3sI/ AAAAAAAAIw4/Hc_wjVrr0Zk/s400/baudelaire888\%25281\%2529.jpg, consultado em $07 / 10 / 2012$ 



\title{
O Satã de John Milton
}

\author{
Fabiano Seixas Fernandes $(U F C)^{5}$
}

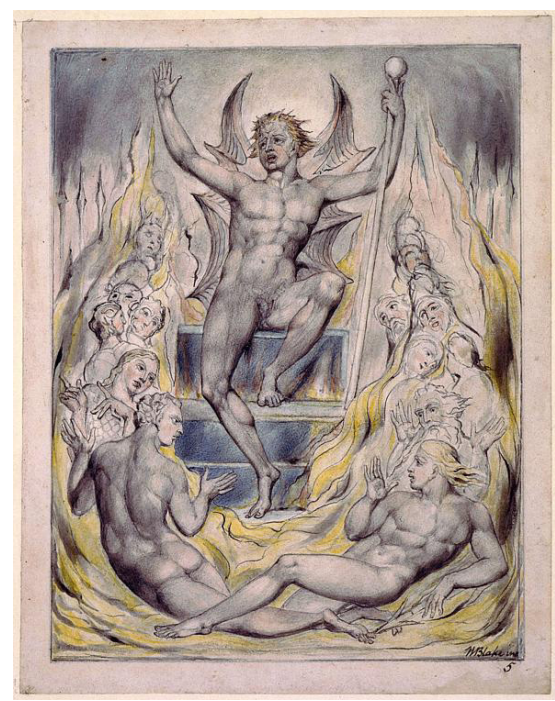

Uma das primeiras discussões que suscita a leitura do poema épico de John Milton (1608-74), Paradise Lost (1667; 2.ed.rev.1674), é o papel que Satã nele desempenha. Sua centralidade inicial e a visão favorável que dele tiveram alguns críticos (em especial, os românticos ${ }^{6}$ ) parece alçá-lo à condição de herói do épico. No que segue, apresento uma breve revisão

5 Possui graduação em Licenciatura em letras: inglês (1999) e Doutorado em Literatura (2004), ambos pela Universidade Federal de Santa Catarina. Atuou como Professor Substituto na mesma instituição (2008-9). Atualmente, é professor de Língua Inglesa e Literaturas pela Universidade Federal do Ceará. Email: fbnfnds@gmail.com.

6 Para um comentário acerca do papel da crítica romântica de Satã, ver Steadman: 1976, pp. 258-60. 
da crítica recente acerca do Satã presente em Paradise Lost (com especial ênfase em publicações em periódicos) ${ }^{7}$; a discussão formal do papel de Satã dentro do poema dará vazão a uma descrição da personagem, organizada a partir de duas estratégias recorrentes de Milton para apresentá-la.

De fato, é opinião difundida entre os críticos que os primeiros dois livros de Paradise Lost parecem estabelecer Satã como herói (ver, por exemplo, Hughes: 1957, p.177). Com a perspectiva destes dois livros centrada no Inferno ${ }^{8}$, observamos a agonia dos demônios (I.60-77, p.213) ${ }^{9}$; seu reerguer-se da torrente de lava (I.331-63, pp.219-20); sua proeza em construir para si um palácio (I.671-751, pp.228-30) e explorar os recursos do Inferno (II.570-628, pp.545-7), buscando superar como lhes for possível a perda de sua antiga glória (II.521-69, pp.244-5); sua aparentemente ponderada discussão acerca de como vencer um oponente a quem descrevem como tirano (II.01-506a, p.232-44). Não são, ainda, para o leitor, propriamente demônios, mas anjos menos lustrosos, empobrecidos em glória por uma derrota.

Satã é certamente o cerne desta descrição. Assistimos sua figura magistral inicialmente prostrada se reerguer da torrente de fogo (I.22130, p.217); ouvimo-lo esconder a própria dor e falar orgulhosamente a Belzebu (I.190-1, p.216) e, em seguida, às tropas (I.315-30, p.219), que, segundo afirma, preferiram-no e o apoiaram (I.101-5a, p.214), e precisam de sua voz para recuperar o moral (I.272b-82, p.218); sentimos sua

7 Os artigos aqui citados - compondo uma seleta certamente parcial de textos versando especificamente sobre o Satã de Paradise Lost—foram primeiramente coletados através de consulta à base virtual de dados do periódico Milton Quarterly, levando-se em consideração principalmente os publicados a partir dos anos 90; em segundo lugar, buscou-se o mesmo tipo de artigo junto ao portal Periódicos CAPES (http://www.periodicos.capes. gov.br/), com foco no mesmo período. Steadman (1976) apresenta uma extensa revisão de literatura acerca da figura de Satã em Paradise Lost de um período anterior àquele em que me concentrei. Agradeço a Daniel Hight Moore Jr por haver me facultado acesso tanto à base de Milton Quarterly quanto ao artigo de Steadman.

8 O que não significa que Milton neles se exima em absoluto de nos direcionar acerca de como deveríamos interpretar Satã. Alguns críticos, porém, prefeririam minorar a importância destas interferências diretas—como, por exemplo, A. J. A. Waldock (apud Steadman: 1976, pp.263-4).

9 Em todas as referências a Paradise Lost, ofereço inicialmente o livro (em numerais romanos) e os versos (em arábicos); a seguir, o número de página pela edição de Hughes (1957). 
inabalável e consciente vontade (I.157-91, pp.215-6); ouvimo-lo aceitar posição de liderança entre os anjos caídos (II.18-25, p.232), declarando que sua tarefa é ainda mais árdua que a deles (razão pela qual não teme ser destronado) (II.24a-35a, pp.232-3); finalmente, vemo-lo se oferecer para se aventurar sozinho no Caos e em um mundo desconhecido, para confirmar os rumores da criação de um novo mundo e de novos seres (II.450b-66a, pp.242-3).

Devido a esta apresentação inicial, é a missão de Satã que nos é inicialmente apresentada como a missão "épica" do poema: desbravar um mundo novo em sua luta contra o Criador. Esta missão faz com que desempenhe papéis semelhantes aos de heróis da épica clássica: guerreiro intrépido (lembrando Aquiles ou Heitor), líder militar (como Enéias), estrategista (como Odisseu), viajante (como todos os três), e mesmo, como aponta Steadman, espião e mestre em disfarces (como Odisseu) (1976: p.269). A ira de Satã —ultrajado pela ascensão do Filho-é semelhante à de Aquiles; sua busca por um novo lar (o novo mundo) em meio ao Caos ecoa a de Enéias, e sua astúcia a de Odisseu.

Contudo, o terceiro livro se inicia com Deus, e seu discurso auto -explanatório (III.80-134, pp.260-1) coloca Satã sob outra perspectiva: um viajante solitário cruzando o Caos sem saber que é observado, sem saber que essa viagem lhe está sendo permitida pelos poderes contra os quais se rebelara (I.211b-20, pp.216-7); alguém cujos planos estão frustrados de antemão, pois previstos desde a Eternidade pela inteligência que tudo criou e sabe (III.77-8, p.260). Já ao final do segundo livro, conhecemos o incesto de Satã com sua filha (Pecado), gerando seu filho/ neto (Morte) (II.648-814, pp.247-51), guardiães das portas do Inferno (II.850-2, p.252). Ao chegar à Terra-após promessas a Pecado e Morte (II.816-44, pp.251-2), ao Caos e à Noite (II.970b-87, p.255), disfarces (III.636-44, p.274) e mentiras ${ }^{10}$ —, veremos seus inúmeros solilóquios

10 A opinião é de Hillier (2009: p.19): para poder viajar, Satã promete ao Caos não invadir seu reino (já invadido pelas criações de Deus); mais tarde, porém, Pecado e Morte constroem uma ponte entre o Inferno e a Terra para mais fácil tráfego dos demônios (X.285b-305, p.413), o que quebraria a promessa de seu pai/amante/avô, avançando sobre os já decrescentes domínios do Caos. É fato que Satã aceita feliz a obra dos consócios (X.385-93a, p.415), mas não a ordenou; não podemos afirmar que haja quebrado explicitamente sua promessa ao Caos. Assim, atesto a opinião de Hillier, mas faço uma ressalva à evidência textual que apresenta. 
(IV.32-113, pp.278-80; IV.358-92, p.287; IV.505-35, p.290; IX.99178, pp.381-3; IX.473-93, pp.389-90): em sua solidão física, seu desespero fica aparente em seu primeiro momento de fraqueza, quando cogita inclusive o arrependimento (IV.79-80, p.279), e revela ser a "tirania" divina não mais que uma ação de graças, honrosa a quem a recebe tanto quanto a quem a oferece (IV.42b-8a, p.278); também a felicidade conjugal de Adão e Eva o aguilhoa em sua solidão desejante e frustrada (IV.505-11, p.290); sente por um momento compaixão e respeito por aqueles a quem se resolve a destruir (IV.361-2a, 373b-6a, 388-92, p.287). Em sua primeira tentativa, havendo habilmente aprendido algo acerca das criaturas cuja ruína busca (IV.514-22a, p.290), os anjos vigilantes o encontram transformado em sapo a sussurrar no ouvido de Eva (IV.800, p.297); veremos seu orgulho ferido ao não se reconhecido pelos anjos que o descobrem (IV.283-43, pp.297-8), e sua primeira fuga (IV.1013-5, p.302). Quando Rafael fizer seu relato da Guerra Celeste aos primeiros pais (V.563-907 e VI, pp.315-43), observaremos Satã novamente como líder militar das massas angélicas (desta vez em ação); veremos suas primeiras derrotas (VI.189-98a, p.328; VI.296-334, pp.330-1)—os primeiros indícios para ele e para nós de que sua força não é o que julgava ser, e que os anjos fiéis, imunes à dor, têm vantagens físicas sobre ele-, sua tentativa de reanimar suas tropas (VI.418-45, pp.333-4) e sua invenção de uma arma (o canhão) para o segundo dia de combates; antes do novo combate, veremos sua postura pouco digna ao mentir uma trégua para esconder sua invenção (VI.558-67, p.337); durante o combate, fará pouco dos inimigos temporariamente abalados pelo poder do canhão (VI.609-27, p.338). Finalmente, observaremos o Filho encher de terror as tropas revoltosas, que por si se jogam no abismo para fugir de uma visão que aos demais anjos enche de maravilha (VI.824-66, pp.343-4). (É a ira do Filho que de fato se assemelha à do Aquiles que volta à batalha, após a morte de Patroclo; a Satã, que sequer pode desafiá-lo a combater homem-a-homem, não caberia o correlato de Heitor.) Quando Satã retornar por si à cena, cruzará numa famosa jornada a Terra por "sete noites contínuas" (IX.48-86, pp.379-80), fugindo da luz e ziguezagueando, até finalmente escolher a serpente como instrumento para tentar Eva (IX.85b-6, p.380; IX.532-781, pp.391-6). Após a queda da humanidade, Satã estará triunfal, retornando ao Inferno para se gloriar de sua conquista (X.460-503, pp.417-8). Neste momento, vemo-lo 
pela última vez, transformado em serpente, rastejando no chão junto a seus asseclas, abrasado por fome e sede, e por elas compelido a comer frutas fictícias sabendo a cinza (X.504-84, pp.418-20).

Como apontam os críticos (McQueen: 1970 em particular $^{11}$ ), e como o resumo acima deixa entrever, Milton constrói uma imagem inicial de Satã que pretende desfazer ao longo do épico. Ao longo de Paradise Lost, Satã é exposto como um anjo vaidoso, incapaz verdadeiramente de frustrar os desígnios divinos, e cujas ações são toleradas por Deus somente para serem punidas quando bem lhe aprouver (III.211b-20, pp.216-7). Satã é progressivamente degradado (Waldock apud Steadman: 1976, p.263; Hughes: 1957, p.177), ou (o que seria mais ao gosto de Milton) se degrada a si mesmo.

Como isso é feito? Em primeiro lugar, através de uma mudança de ponto-de-vista. McQueen (1970: p.60) crê que a perspectiva fechada dos dois primeiros livros vai se abrindo com o desenrolar do poema, de modo que a personalidade de Satã e sua real condição se mostram por completo, até sua última e mais humilhante aparição, transformado em serpente. Assim, com o acréscimo de dados vindos de outras fontes-os monólogos de Satã, os discursos de Deus sobre como reverterá a revolta de Satã em benesses aos homens, o relato da Guerra Celeste feita pelo anjo Rafael a Adão e Eva-podemos reinterpretar a impressão forte causada pelos primeiros livros. Por sua própria confissão, seu companheirismo inicial redunda em sedução de seus companheiros (IV.83, p.279), e a tirania divina oferece muito mais do que exige (IV.42-8, p.278); a descrição feita por Rafael da guerra nos céus mostra que suas táticas são traiçoeiras (mentir, esconder armas); mostra ainda que sua destreza militar é menor do que dá a entender, uma vez que a própria queda o tornou mais vulnerável e propenso à dor-essas derrotas militares o farão futuramente menos propenso ao embate que ao embuste-; sua coragem ao se aventurar sozinho pelo Caos pode ser então reinterpretada como vaidade; sua descrição de sua "eleição" por seus pares é

11 McQueen de fato avança essa ideia em outro artigo que não o citado aqui; neste, porém, resume-a como segue: "In an earlier paper, I suggested that in Book I [...] Milton's use of a limited point of view [...] deliberately distorts the action to establish Satan initially as a serious adversary of God, only to reveal through a gradual widening focus the falsehood of such an assumption" (1970: p.60). 
comprometida por sua confissão de que os seduziu, e mais ainda pelo fato de que é oriunda de Deus, que o havia colocado acima dos anjos que convencera e comandara à rebelião (II.18-9, p.232). Embora sincera em certa medida (IV.86-9, p.279), sua descrição das agruras da liderança é preventiva de traição, uma vez que é o próprio Satã um insurreto; as dúvidas que lança publicamente acerca do direito de Deus a reinar nos céus e de seu poder criador (V.853-66a; p.322) são contraditas por sua plácida aceitação dos mesmos quando está só (IV.43, p.278) ${ }^{12}$.

Em segundo lugar, inúmeros críticos apontam a pesada labuta intertextual de Milton. Satã é aproximado de diversas figuras da mitologia clássica, seja via símile, seja pela apropriação recreativa que Milton faz de certos trechos de obras da Antiguidade clássica e da Idade Média; quando vistas mais de perto, as comparações são negativas em ao menos um dos dois sentidos:

A comparação desfavorece Satã por semelhança ou diferença. ${ }^{13}$ Cito alguns estudos. Maggie Kilgour (2008) compara o papel desempenhado por Satã em Paradise Lost ao de Juno na Eneida:

Like Virgil's Juno, Satan both sets the plot in motion and then tries to delay its inevitable, ordained end. Juno and Satan are both associated with confusion, transgression, and boundary breaking [...]. They thus oppose the figures of Jove and Jesus, who, as the Son's appearance in Paradise Lost book 6 also indicates, are both connected with order, closure, and the setting of limits through discrimination and differentiation. (2008, p.654.)

12 Embora seja fato que sua opinião oscile mesmo quando está só. Por exemplo, seu primeiro monólogo no livro IX se inicia com um elogio à Terra e termina fazendo dela pouco. Certamente, o reconhecimento se dá em um momento inicial do monólogo; Satã é momentaneamente abalado por dúvidas também quando vê Eva e se deixa levar por sua beleza (IX.444-72, p.389). Quando se torna mais autoconsciente, porém, retoma sua atitude desafiadora-o que talvez indique que é uma tomada de atitude, não uma postura natural e sincera. Talvez possamos inferir disso que tamanha é, para Milton, a bondade e a generosidade divinas, que mesmo resisti-la se torna uma tarefa penosa, feita a muito custo.

13 A aproximação entre Satã e Tideu se dá através de uma personagem intermediária, sendo que Tideu nunca é mencionado em Paradise Lost. Essa cadeia de transferências (porque Tideu é como Briareos e Briareos é como Satã, Satã é como Tideu) parece exigir demais mesmo de um leitor familiarizado com os intertextos de Milton. 
Ambas as personagens apresentam emoções destrutivas, e estão relacionadas à procrastinação de eventos pré-determinados—a fundação de Roma por Enéias e a redenção da humanidade - aos quais não podem evitar; ao final, evidencia-se que suas tentativas de interferir acabam por serem instrumentais aos desígnios superiores:

The end of the narrative [da Eneida] thus seems to reaffirm a hierarchical cosmic order, in which reason prevails over passion, male over female, epic over romance, telos over suspense. What appeared to be a dualistic world, caught in a struggle between two equal antithetical principals, is resolved through subordination [...] (Kilgour: 2008, p.656.)

John Mulryan (2005) explora o óbvio intertexto entre o nascimento de Pecado e o de Palas Atena-ambas nascidas adultas das respectivas cabeças de Zeus e Satã. Segundo Mulryan, "whether the myth of Athenas's birth is interpreted positively or negatively, it still redounds to the discredit of Satan, undermining his self-esteem with scorn, derision, and contempt" (p.16). Mulryan se baseia na interpretação dada ao mito do nascimento de Atena por três mitógrafos do século XVI: dar à luz é um processo femininzante (e extremamente doloroso) tanto para Zeus quanto para Satã, que os submete às dores do parto; finalmente, enquanto Zeus dá à luz o conhecimento, Satã não gera senão ignorância.

Irene Samuel relaciona a transformação final de Satã em serpente aos procedimentos alegóricos de Dante na Comédia: "Only Dante could have suggested to Milton the idea of having the scene represent the penalty exacted by divine justice - that the criminal must go on being and doing involuntarily what he formerly was and did by choice" (apud Butler: 2006, p.148).

Phillip Cardinale (2003) e Katherine Calloway (2005) comparam Satã e Enéias. Cardinale comenta I.125-6, passagem na qual um comentário acerca de Satã (que esconde o próprio desespero enquanto fala a Belzebu) parafraseia um comentário presente na Eneida acerca de Enéias (que também tenta esconder suas dores ao se dirigir às tropas):

The allusion ennobles the false face that Satan puts on to cheer his troops. The substance of Satan's speech echoes that of Aeneas in themes of destiny and perseverance. The difference is that where Aeneas urges faith in divine providence, Satan 
exhorts divine vengeance. Milton thus empowers Satan with the political acumen of Virgil's hero, but at a subtler level reminds the reader that Satan lacks Aeneas's defining trait, piety. (Cardinale: 2003, p.183.)

Como, no trecho em questão, Satã fala não às tropas, mas exclusivamente a Belezebu, Calloway acrescenta outra negativa: "he appears to be pulling himself together rather than trying to boost the morale of his followers" (2005, p.84).

Além desta, Calloway abordará duas outras passagens em que Milton parafraseia a Eneida de modo a suscitar a comparação entre Satã e Enéias - em todas, a atitude de Enéias difere da de Satã, enfatizando os deméritos deste. No trecho em que Eva come a maçã, a descrição do estremecimento da terra frente ao crime da mulher (IX.781-3, p.396) é oriunda de descrição semelhante quando do casamento da rainha Didone e de Enéias em uma caverna. Satã, aqui, incorpora tanto o papel de Enéias como amante como o de Vênus, que deseja a ruína de Didone (Calloway: 2005, p.86). Finalmente, o aparecimento de Satã em seu trono em meio a uma nuvem no Inferno (X.449-51, p.417) lembra a igualmente nublada aparição de Enéias a Didone, ocasionada por Vênus. Calloway comenta:

Satan wills his own concealment in, and emergence from, the cloud. Aeneas thus submits again to the will of someone greater [Vênus] while Satan refuses to concede the existence of such a person. This difference in attitude is evident in the way each behaves after his miraculous appearance. Satan immediately begins to boast, not entirely truthfully, of his many brave exploits and the success of his journey. Aeneas, on the other hand, shining and god-like as he is, describes his band as worn-out and unable even to thank Dido properly for her welcome. As was the case when both Satan and Aeneas suppressed despair in order to speak courageously, Satan's tone is arrogant while Aeneas' is forbearing. (2005, p.87.) 
Finalmente, George F. Butler (2006) traça uma cadeia de relações entre os Briareos (monstro gigantesco de cinquenta cabeças e cem braços) e Tideu (chefe militar retratado na Tebaída de Estácio, que come o cérebro de Melanipo, morto em combate) e Satã - servindo-se, para isso, de símiles presentes na Eneida, na Tebaída e na Comédia e que seriam direta ou indiretamente retomadas em Paradise Lost ${ }^{14}$.

A comparação demonstra a superioridade do ponto-de-vista cristão frente aos valores da épica clássica ${ }^{15}$. Apesar de seu enorme conhecimento

$14 \mathrm{O}$ método de Butler me parece falho, por isso o comento à parte. Segundo Butler, "Milton's comparison of Satan to Briareos reminds us that Statius had compared Tydeus to the same monster. And so Satan is indirectly related to Tydeus through Milton's simile" (2006, p.140, grifo meu). Ou seja, ao ler a símile de Milton (Satã é como Briareos), o leitor deveria se lembrar de outra, presente na Tebaída (Tideu é como Briareos), para inferir uma terceira, intertextual e indireta (Satã é como Tideu). Vejo dois problemas aqui:.

15 É necessário que nos indaguemos acerca dos limites da símile. Creio que Butler transfere características demais de uma personagem a outra. Vejamos: Virgílio compara Enéias em combate a Briareos em combate quanto a poder bélico; Estácio compara Tideu em combate a Briareos em combate quanto a tamanho (aqui, o gigantismo é fácil sinônimo de poder bélico); finalmente, Milton compara Satã a Briareos quanto a tamanho (sem, porém, conotação de poder bélico: assim como Satã está neste momento prostrado na torrente de lava, creio ser lícito imaginar Briareos prostrado ao chão após sua derrota por Zeus). Butler deseja que, da comparação física entre Satã e Briareos, possamos inferir uma comparação moral entre Satã e Tideu: Satã tem o mesmo tamanho de Briareos; Briareos é ímpio como Tideu; logo, Satã é ímpio como Tideu.

É lícito compararmos moralmente personagens comparadas fisicamente? Se assim for, a impiedade de Briareos também deveria tocar a Enéias, posto que ambos são comparados na Eneida; dada, porém, a descrição criticamente pacífica de Enéias como pius, Butler (que reconhece a símile) não faz a transferência da igualdade em destreza bélica à correção religiosa e moral neste caso.

A isso se acresce o fato de que, para embasar sua cadeia de símiles, Butler afirma que a fonte de Milton para "Satã é como Briareos" é a Tebaída, não a Teogonia: na Eneida e na Tebaída, Briareos é descrito como inimigo de Zeus, contrariamente ao que ocorre na Teogonia e na Ilíada (Butler: 2006, pp.135-40). Não vejo razão para isso; apesar de a caracterização de Briareos em Paradise Lost estar bastante próxima à presente na Tebaída, Milton não poderia simplesmente esquecer ou ignorar seu conhecimento da Teogonia ao escrever.

Certamente, trata-se de três personagens que se revelam ímpias em situações de combate: Satã se rebelara contra Deus, Briareos contra Zeus e Tideu canibalizara um inimigo morto-esses fatos, por si, permitiriam comparação. Mesmo assim, creio que as comparações de Butler não podem ser tomadas como evidência certeira das fontes textuais de Milton, muito menos como chaves de interpretações propositais do poeta, embora, como comparações originais, iluminem nossa compreensão de Satã 
clássico e do respeito que nutre por autores clássicos, Milton também tomará parte da revisão de seus valores a partir da perspectiva cristã.

Um dos mitógrafos mencionados pelo supracitado estudo de John Mulryan (2005: pp.19-20) expõe o ridículo de Zeus dando a luz ao Conhecimento na ferraria de Hefesto, e com a ajuda deste; os pagãos, mesmo quando produzem conhecimento, não conseguem fazê-lo fluir naturalmente (i.e. pela boca), tendo de abrir à força um outro orificio para que saia. $\mathrm{O}$ aspecto potencialmente risível do nascimento de Atenas, apontado pelo mitógrafo, poderia ser transferido talvez ao nascimento do Pecado da cabeça de Satã.

Este tipo de contraste, porém, é comentado normalmente quando os críticos enfocam a relação entre Satã e o Filho. Aventando uma opinião difundida entre a crítica, Butler comenta que Paradise Lost apresenta o contraste entre o "classical heroism of Satan" e o "Christian heroism of the Son” (2006, p.134). Em artigo específico comparando Paradise Lost e a Eneida, Butler comenta que o Filho é quem mais se aproxima de Enéias, embora as qualidades menos louváveis do herói troiano estejam presentes em Satã (Butler: 1997 apud Calloway: 2005, p.83). Também Calloway, ao tratar do paralelo entre as personagens de Enéias e Satã, conforme exposto acima, procura demonstrar que Milton aproxima Satã de Enéias para que suas diferenças sejam enfatizadas (2005, p.82)—o que contaria pejorativamente para Satã. Rebaixar Satã através do uso de intertextos-especificamente de Enéias, o herói clássico cuja pietas mais se aproxima dos valores cristãos $^{16}$, mas que nem por isso deixa de ser e agir ocasionalmente como pagão—cumpre não apenas a função de caracterizar o quedo arcanjo como personagem, mas também a de contrastar a moral e os métodos do heroísmo tradicional aos do heroísmo

16 Calloway afirma que Enéias "fits neither the classical nor the Miltonic ideal of a hero"; para ela, a grande diferença entre Satã e Enéias reside no fato de que "Aeneas accepts and makes the best of those situations into which he is thrown by fate and the gods, while Satan fiercely opposes, and indeed denies, any authority that supersedes his own". Também afirma que, ao escolher Enéias como modelo para imitação na construção de Satã, Milton "argues that even the most Christian of all pagan heroes fails to realize this higher standard" (todas as citações Calloway: 2005, p.88). Apesar de não negar a validade interpretativa da última asserção, confesso ter certa dificuldade em compreendê-la como um desejo direto de Milton sem conhecimento de evidência direta de que Milton considerasse de fato Enéias como "the most Christian of all pagan heroes". 
cristão ao quais Milton deseja exaltar: "the better fortitude / Of Patience and Heroic Martyrdom” (IX.31-2, p.379).

O estudo de Russell M. Hillier (2009) acerca de "fraud and force"as duas táticas militares comumente empregadas no heroísmo clássico, cujas mais puras manifestações são exemplificadas pela sanha assassina de Aquiles e pelos ardis de Odisseu-demonstra a constância dessas atitudes na fala e nos atos de Satã, bem como nos comentários acerca destes feitos por Milton:

Force and fraud, I am arguing, can be seen to relate to the Satanic heroic mode across Paradise Lost and Paradise Regained as a pejorative revaluation of both the ancient heroic code-as ancient epic is arguably foundational for the force-fraud collocation - and the Renaissance political philosophies of Machiavelli and Milton's contemporary, Thomas Hobbes. Set against the Satanic mode, an opposing Messianic mode of heroism can be evinced, the revealed Miltonic hero, who is exemplary, if not to a nation, then to Milton's readers, fit though few. (2009, pp.17-8.)

Finalmente, além de seu conhecimento de literatura clássica, Milton também usa seus vastos conhecimentos geográficos para demonstrar a decadência física e moral de Satã. Em seu estudo, Sherry Lutz Zivley descreve a supracitada a rota da Satã na escuridão após haver fugido do Éden e antes de decidir encarnar na serpente para tentar Eva (IX.48-86, pp.379-80), chegando à seguinte conclusão:

Having determined to rebel against God, Satan is no longer capable of being straightforward-not even in his travels. He cannot move with clear direction. Instead, he is driven with an careening [sic] frenzy. Although God and the angels can travel between Heaven and earth with lightning speed without assistance, Satan needs longer to find his way to Eden than God needed to create the earth. Yet the analogy with the seven days of creation is significant. In seven days God created the world and rested. But in the seven days of Satan's equinoctial 
and colurian orbits, he accomplishes nothing. $\mathrm{He}$ ends up at exactly the spot in the universe from which he began. And he certainly finds no rest. (1997, pp.134-5.)

Ademais, os críticos apontam o uso instrumental que Satã faz de $\operatorname{todos}^{17}$, seu orgulho desmesurado, seu potencial destrutivo e autodestrutivo. Rejeitando a autoridade divina, a fonte de toda a vida e de toda a criação, Satã pode apenas se isolar em si mesmo, em sua vontade. E essa vontade encontra pouca escolha senão ser oposta à do Criador-daí sua propensão ao ódio, à destruição e a ruína, de si tanto quanto do resto. Seu castigo final, convertido em serpente, é alegórico à maneira de Dante (conforme aponta Irene Samuel no estudo citado por Butler [2006]). O bravo movimento de se erguer das chamas e se desprender de correntes por um ato volitivo acima da própria dor em sua primeira aparição contrasta com seu rastejar involuntário e transformado em serpente em sua aparição final. Sua vontade, que até então o guiara, revela-se pelo que é: pulsão incontrolável que leva à frustração e à morte (a fruta com aparência de vida, mas com sabor e textura de cinzas).

17 Hillier (2009) cita um estudo de Simone Weil (1956) acerca da Ilíada, no qual a filósofa advoga ser força o conceito central do épico homérico, e a descreve como sendo "that $x$ that turns anybody who is subjected to it into a thing" (Weil: 1956 apud Hillier: 2009, p.29). Hillier acredita que "Milton's Satan fits Weil's category $x$, because he understands all matter and phenomena that are creative expressions of God's intrinsic goodness to be functional and reducible to instruments only valid in accomplishing his own self-glorification. The angels Lucifer leads into battle, the complicity of Sin and Death, his pact with Chaos and eternal Night, and the innocence of Adam and Eve are for Satan all ontologically degradable to means used by which he might set himself higher. [...] Like Weil's intoxicated Homeric hero, a proponent of desolating force, Milton's characterization of Satan delineates the deleterious psychological development of an essentially unattractive 'hero' for whom 'onely in destroying I finde ease', a debased figure tragically divided against everyone, everything, and even itself' (2009: p.29). 


\section{Bibliografia}

Butler, G. F. The fall of Tydeus and the failure os Satan: Statius' Thebaid, Dante's Commedia, and Milton's Paradise Lost. In: Comparative Studies in Literature, vol.43, n.01-2. Penn State University Press, 2006, pp.134-52.

Calloway, K. Beyond parody: Satan as Aeneas in Paradise Lost. In: Milton Quarterly, vol.39, n.02. Wiley, 2005. pp.82-92.

Cardinale, P. Satan as Aeneas: An Allusion to Virgil in Paradise Lost. In: Notes and Queries, n. 248. Jun/2003. p.183.

Hillier, R. M. "By force or fraud / Weening to prosper": Milton's Satanic and Messianic modes of heroism. In: Milton Quarterly, vol.43, n.01. Wiley, 2009. pp.17-38.

Kilgour, M. Satan and the wrath of June. In: English Literary History, vol.75, n.03. The John Hopkins University Press. outono/2008. p. 653-671.

McQueen, W. A. “The hateful siege of contraries": Satan's interior monologues in Paradise Lost. In: Milton Quarterly, vol.04. n.04. Wiley: dez/1970. p. 60-65.

Milton, J.; Hughes, M. Y. (ed.). Complete Works and Major Prose. Indianapolis: Hackett, 1957, reimp.2003.

Mulryan, J. Satan's headache: the perils and pains of giving birth to a bad idea. In: Milton Quarterly, vol.39, n.01. Wiley, 2005. p.16-22.

Shawcross, J. T. An early view of Satan as hero of Paradise Lost. In: Milton Quarterly, vol.32, n.03. Wiley: out/1998. p. 104-105.

Steadman, J. M. The idea of Satan as the hero of Paradise Lost. In:

Proceedings of the Amerian Philosophical Society, vol.120, n.04 (Symposium on John Milton). 1976. p. 253-294.

Zivley, S. L. Satan in Orbit: Paradise Lost: IX: 48-86. In: Milton Quarterly, vol.31, n.04. Wiley: 1997. p. 130-136.

\section{Imagem}

Satã por William Blake. Disponível em http://escamandro.files.wordpress.com/2012/07/william-blake-satan-in-council.jpg, consultado em $07 / 10 / 2012$ 



\section{Uma comparação entre os Satãs do Paradise Lost e Paradise Regained}

Paloma Catarina Zart (UFSM) ${ }^{18}$

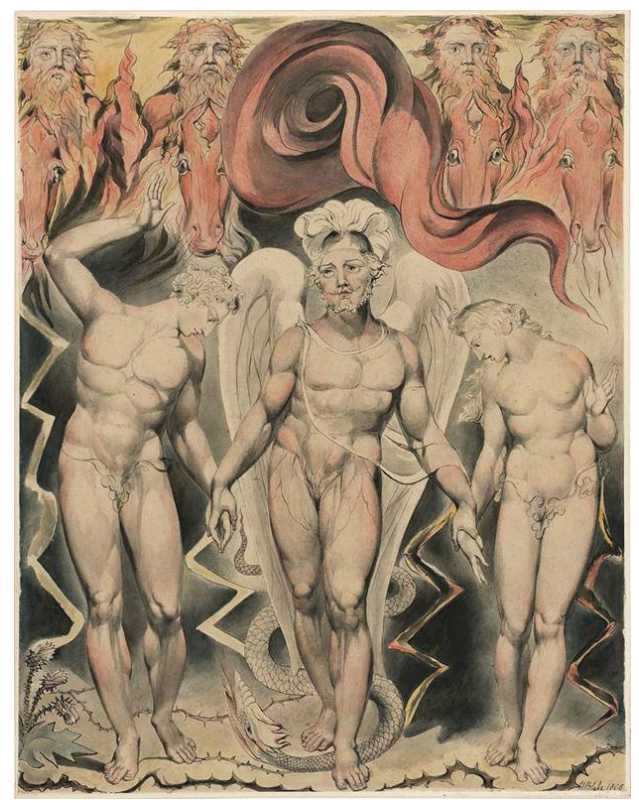

Barbara K. Lewalski (2003) lembra duas anedotas acerca dos épicos miltonianos. Ao fim da composição de Paradise Lost, Milton entregou o manuscrito a um amigo para que este o lesse, ao devolver o texto, o amigo haveria dito estar ansioso para ler a continuação do título. A outra anedota está ligada ao editor, responsável pela publicação do épico. Diante da boa aceitação do título miltoniano, o editor haveria pedido

18 Doutoranda pelo Programa de Pós-Gradução em Letras da Universidade Federal de Santa Maria. Bolsista CAPES. Email: paloma.zart@gmail.com 
um segundo livro. Surgiria destes pedidos a primeira ideia para o Paradise Regained. Independente da veracidade dos episódios é constantemente levantada a possível sequência entre eles, algo fortalecido pela semelhança entre os títulos, bem como pelas suas temáticas. Enquanto que Paradise Lost narra a perda do paraíso terrestre e, em consequência, do celeste; Paradise Regained apresenta a promessa da recuperação do paraíso áureo, revelando, com isso, um movimento contínuo. Ao nosso entender, no entanto, os épicos não são uma continuidade, prova disto está nas personagens dos títulos, em especial na representação de Satã apresentada nas duas obras. Os diabos são distintos ao ponto de terem como única semelhança o nome que envergam e a função tentadora que exercem sobre outras personagens. Analisados em profundidade, os dois Satãs são tão distintos quanto o dia da noite.

Várias são as fontes de influência que podem ter sido utilizadas por Milton para a construção do Satã do Paradise Lost, ao passo que o Satã do Paradise Regained encaixa-se somente em uma destas fontes ${ }^{19}$. Neil Forsyth (2003) lembra, sumariamente, o complexo espectro de possíveis construções para a compreensão de S1, sendo que a análise da personagem pode variar da perspectiva puramente literária, com suas raízes na literatura grega, até a uma abordagem exclusivamente teológica. Essa gama de possíveis aproximações torna extremamente flexível uma determinação da personagem como, por exemplo, protagonista ou antagonista no épico, tudo dependendo da perspectiva argumentativa adotada.

O mito do combate é exemplar desta maleabilidade. Assevera Forsyth (2003) que o mito está relacionado com a polarização de forças, sendo uma delas dominante, enquanto a outra, dominada, tenda destronar a primeira. Uma análise inicial deste espectro coloca em posições fixas os polos, há um rebelde que, normalmente, será considerado como o lado negativo. A simples observação de qual dos dois postos é ocupado por quem, no entanto, não encerra a complexidade envolvida neste mito. Na Teogonia, Hesíodo apresenta uma versão do mito do combate. Nele, Zeus é apresentado como o lado positivo, apesar de ser o rebelde. A construção da narrativa permitiu que Hesíodo apresentasse Urano como um déspota, capaz de devorar sua prole para defender sua posição. Neste

19 Para fins de desambiguação o Satã do Paradise Lost será nomeado, doravante, S1, enquanto que o Satã do Paradise Regained, S2 
caso, a revolta de Zeus, observa Forsyth (2003), embasada no destronamento de um tirano, passa a ser vista como positiva e aceitável. Ou seja, a construção narrativa de Hesíodo, escolhendo o lado de Zeus, reverte a noção inicial do mito do combate (Forsyth, 2003).

A presença massiva de fontes, mitos e episódios, no Paradise Lost, permitiu a Milton construir uma personagem que não pode ser determinada, sem perdas significativas. Em Paradise Regained, porém, o domínio de uma única fonte, o relato de Lucas, e uma ação singular, a tentação de Jesus no deserto, crava a caracterização de S2.

\section{A complexidade de Satã no Paradise Lost}

Uma personagem redonda, definida por E.M. Forster (2010), é aquela capaz de surpreender de modo convincente. Ainda, é impossível, continua Forster, defini-la em uma sentença ou lembra-la por si só, ou seja, sem elencá-la a um conjunto de episódios. O crítico, ao fazer essas afirmações, pensava na personagem de romance, mas as assertivas são extensíveis a outros gêneros. Ao Satã do Paradise Lost, por exemplo, as definições são muito apropriadas, pois, não é possível defini-lo somente como o tentador do homem que busca vingança, e, ainda, a percepção desta personagem envolve a indicação de cenas. Em suma, S1 exige mais esforço daqueles que tentam analisá-lo.

A complexidade de Satã está relacionada às posições assumidas ao longo da narrativa épica, bem como nas relações estabelecidas com outras personagens. Passado e presente de S1 são relatados no épico, revelando a evolução da personagem e a necessidade que enfrenta para se adaptar e compreender o que está vivenciando. Para tanto, em determinadas situações, o anjo rebelado precisa enfrentar seus fantasmas e definir sua posição. Os solilóquios são a representação deste momento crucial, pois, é quando S1, sozinho e tendo diante de si toda a criação, se deixa conduzir por todos os pensamentos que o atormentam. Nestes momentos, Satã é triforme (Carey, 2008), uma vez que apresenta traços de seu passado angélico - como arcanjo - e as marcas de seu presente infernal - como Príncipe das Trevas e serpente tentadora. 
Para John Carey, o entendimento de que a queda angélica é de responsabilidade do próprio arcanjo representa um destes momentos em que a natureza triforme de Satã é evidente:

In it, Satan concedes his own criminality, and his own responsibility for his fall. He vacillates between remorse and defiance. He confesses that his rebellion was completely unjustifiable, that he had the same 'free will and power to stand' as all God's creatures, and that he therefore has nothing to accuse but 'heaven's free love dealt equally to all'. Since heaven's love means his own damnation, he curses it ('Be then his love accursed'), but then, rationally, turns his curse against himself ('Nay, cursed be thou'). Satan could be called evil at this point of the poem only in some attenuated sense, since he speaks the truth and curses himself as God curses him. He and God are in accord. (CAREY, 2008, p. 163) ${ }^{20}$

A admissão de culpa, porém, não significa o cessar dos conflitos de Satã ou a aceitação pacífica do destino que aguarda o anjo. Os embates internos continuam ao longo da narrativa épica e são superados na medida em que S1 aceita, definitivamente, sua condição de caído. A reiterada afirmação do mal, que finaliza os cinco solilóquios satânicos provam a constante necessidade de lembrar a nova posição da personagem na estrutura tripartida do universo. Admitir a queda está relacionado à compreensão da perda e a aceitação de um papel secundário. $\mathrm{O}$

20 Nele [primeiro solilóquio], Satã reconhece sua criminalidade e sua responsabilidade pela queda. Ele vacila entre remorso e provocação. Confessa que sua rebelião era injustificável e que tinha o mesmo 'livre-arbítrio e força para permanecer' como todas as criaturas divinas, portanto, não tinha nada a acusar senão 'o livre amor do céu igualmente distribuído'. Uma vez que o amor celeste significa sua própria condenação, ele o amaldiçoa ('Seja seu amor amaldiçoado'), mas, em seguida, racionalmente, transfere sua maldição a si ('Não, seja tu amaldiçoado'). Satã pode ser chamado de mal, neste ponto do poema, somente em um sentido atenuado, pois fala a verdade e amaldiçoa a si como Deus o amaldiçoa. Ele e Deus estão de acordo. Tradução da autora. 
reconhecimento do amor divino, como enfatiza Carey (2008), demonstra que Satã não esqueceu completamente sua posição na hierarquia celeste, no qual seu papel estava delimitado de acordo com o que era esperado dos anjos.

David Masson (1874) defende que a queda fora mais prejudicial ao seu líder do que aos outros anjos que o seguiram. Ainda no primeiro solilóquio, Satã lembra o sentimento de eterna dívida imposto sobre os seres celestes ("The debt immense of endless gratitute,/ So burdensome still paying, still to owe; $)^{21}$, condenados a pagar com honrarias e louvores um débito não compreendido. Fruto do tempo, mas sem registros do momento, a personagem indaga a capacidade divina para gerar a vida e acredita que sua existência resulta da autocriação. Durante o concílio rebelde, ainda nos domínios celestes, ao proclamar-se capaz de criar, o arcanjo se equipara com Deus e evidencia a visão equivocada do poder que detinha na estrutura celestial. Masson (1874) atribui a uma inabilidade de assimilar a própria posição um dos motivos por trás da queda do anjo. Como um dos quatro arcanjos, Satã era designado para executar ordens divinas. Para tanto, era-lhe concedida uma parcela de poder, a qual the permitia o cumprimento das demandas. Inebriado por este poder momentâneo e limitado, a personagem passa a acreditar que essa faculdade concedida lhe pertencia de fato e de direito.

Após a queda, algumas situações permitem que Satã viva essa posição de poder. Diante das hostes caídas e de seus herdeiros, Pecado e Morte, o anjo posiciona-se de modo a respaldar uma posição hierárquica superior e paternal. A postura assumida por Satã nestes episódios é distinta daquela testemunhada quando a personagem encontra-se sozinha. Nos discursos para as hostes e os herdeiros, S1 revela uma certeza e segurança inexistente nos solilóquios. Isso ocorre porque há uma necessidade de convencer aos outros sobre o percurso percorrido - a guerra celeste e a reclusão no inferno - a fim de angariar o auxílio dos mesmos na execução de novos planos - a tomada do Éden e corrupção de seus habitantes.

21 O débito imenso de eterna gratidão/ Oneroso, sempre pagando e sempre devendo. Tradução da autora. 
Diante de testemunhas, o ex-anjo assume a liderança e demonstra uma segurança que não corresponde com as dúvidas e as incertezas expostas nos solilóquios. A natureza triforme de Satã, apontada por Carey (2008), revela-se nesta contradição entre o exterior e o interior da personagem. A ação, representada na segurança exterior, contraposta à observação dos fatos, apresentada nos solilóquios, vem confirmar a afirmação de Masson (1874), de que o Satã miltoniano, do Paradise Lost, vive um momento de escolha, na qual precisa decidir sua posição, assumindo-se, definitivamente, como o adversário e, consequentemente, esquecendo qualquer possibilidade de perdão.

\section{A linearidade de Satã no Paradise Regained contraposta à complexidade de Paradise Lost}

Defendemos a tese de que os Satãs do Paradise Lost e do Paradise Regained não são os mesmos. $\mathrm{O}$ argumento basilar desta hipótese encontra-se nas divergências entre as duas personagens. A primeira delas refere-se ao grau de complexidade com que são representadas por Milton. Enquanto S1 é uma personagem redonda, S2 é plana. Posto que, contrária à personagem dita redonda, a plana, lembra Forster (2010), é aquela que não passa por nenhum processo que resulte em alguma modificação no modo como ela age ou em suas crenças. Novamente, deve-se observar, as colocações de Forster foram apresentadas com relação à personagem de romance, mas podem ser úteis na compreensão de atores em outros gêneros.

De modo análogo com a simplicidade da personagem, a trama de Paradise Regained também é simples. Completamente centrada na tentação de Jesus no deserto, o épico está embasado na história de Jó, considerada modelo por Milton, e em Lucas (RADZINOWICZ, 2008). Não há oscilação temporal na peça ou qualquer modificação na polarização entre as personagens. Tudo, inclusive os atores, é voltado para a ação singular que transcorre no épico, ao ponto de Kerrigan, Rumrich e Fallon (2007) observarem que tanto o Satã quanto o Cristo representado na narrativa não lembram seu passado: 
We deduce that while Satan knows that Jesus is the woman's seed destined to bruise his head [...] he does not recognize in Jesus the Son of Book 6 of Paradise Lost, whose elevation prompted his envious rebellion and whose decisive appearance on the third day of the war drove him and his troops from Heaven. Jesus also indicates no knowledge of those cosmic events. He understands by searching the Scriptures that he is the prophesied Messiah, destined to redeem mankind and deliver a weakening blow to Satan [...] but he does not realize that defeating Satan belongs to his divinity as much as to his humanity. (p. 634) ${ }^{22}$

A observação dos críticos reforça a compreensão de que as personagens demoníacas representadas nos dois épicos miltonianos não são, de fato, a mesma. Caso a hipótese fosse válida, teríamos de encontrar no Paradise Regained um Satã capaz de recordar e reconhecer seu inimigo dos tempos cósmicos. Tem-se no épico, no entanto, uma personagem que pode ser facilmente aproximada, em um sentido muito largo, das morality plays medievais, posto que o sentido didático destas parece estar presente no último escrito de Milton. Morality plays, de acordo com a definição da Enciclopédia Britânica, são dramas alegóricos em que lições morais eram ensinadas por meio de personagens que personificavam qualidades morais ou abstrações.

Uma terceira divergência está no modo como o antagonismo entre Satã e Jesus é construído. O diabo apresentado no Paradise Regained lembra a mão esquerda de Deus, uma vez que ele age conforme estabelecido, conduzindo as tarefas sujas necessárias para a realização dos desígnios divinos, de modo bastante semelhante à compreensão de Luther Link

22 Deduzimos que enquanto Satã sabe que Jesus é a semente da mulher destinada a pisar sua cabeça [...] ele não reconhece em Jesus o Filho do canto 6 do Paradise Lost, cuja elevação provocou sua inveja e cuja aparição decisiva no terceiro dia de guerra lançou-o e suas tropas para fora do Céu. Jesus também não demonstra nenhum conhecimento destes eventos cósmicos. Ele compreende, pela leitura da Escritura, ser o Messias profetizado, destinado para redimir a humanidade e desferir o golpe final em Satã [...] mas ele não entende que vencer Satã pertence a sua divindade tanto quanto à sua humanidade. Tradução da autora. 
(1998) sobre o papel desta figura mutável e nefanda que acompanha a sociedade ocidental. Não há questionamentos por sua parte, mas a simples aceitação do papel a ser desempenhado. Isso lembra, novamente, Masson (1874) e encerra a questão, momentaneamente.

A distinção maior entre os dois Satãs está no fato de S1 ter um passado, um presente e a perspectiva de um futuro, ao passo que S2 não tem passado ou futuro, somente o presente no qual cumpre sua tarefa. Afirmamos que o Satã do Paradise Lost é vítima da culpa cristã ao passo que o Satã do Paradise Regained está livre dela. 


\section{Bibliografia}

CAREY, J. Milton's Satan. IN: DANIELSON, D. (ed.). Cambridge

Companion to Milton. Cambridge: Cambridge University Press, 2nd ed. 8th print, 2008, p. $160-174$.

ENCYCLOP EDIA BRITANNICA. Em sua versão digital disponível em http://www.britannica.com/EBchecked/topic/391805/morality-play

FORSTER, E. M. Aspects of the novel. New York: RosettaBooks, 2010. Versão digital para e-readers.

FORSYTH, N. The Satanic Epic. Princenton: Princenton University Press, 2003.

KERRIGAN, W.; RUMRICH, J.; FALLON, S. The complete poetry and essential prose of John Milton. New York: Modern Library, 2007.

LEWALSKY, B. K. John Milton: a critical biography. Oxford: Blackwell Publishing, 2003.

LINK, L. O Diabo: a máscara sem rosto. Tradução Laura Teixeira Mota. São Paulo: Companhia das Letras, 1998.

MASSON. D. Three Devils: Luther's, Milton's and Goethe's. IN: Three Devils: Luther's, Milton's, and Goethe's. With other essays. London: Macmillan \& Co, 1874, p. 3-58.

MILTON, J. Paradise Lost; Paradise Regained. IN: KERRIGAN, W.; RUMICH, J.; FALLON, S.M. (eds.) The Complete Poetry and Essential Prose of John Milton. New York: Modern Library, 2007, p. 251 - 630; $631-697$.

RADZINOWICZ, M. A. How Milton read the Bible: the case of Paradise Regained. IN: DANIELSON, D. (ed.). Cambridge Companion to Milton. Cambridge: Cambridge University Press, 2nd ed. 8th print, 2008, p. 202-218.

\section{Imagem:}

Expulsão do Paraíso, William Blake. Disponível em http://escamandro. files.wordpress.com/2012/06/william_blake-the_expulsion_of_adam_and_ eve_from_the_garden-of-eden.jpg 



\title{
Algumas considerações sobre o Diabo na Divina Comédia
}

\author{
Daniel Lula Costa (UEM) ${ }^{1}$ \\ Solange Ramos de Andrade (UEM) ${ }^{2}$
}

Desde a Antiguidade o cristianismo professa a salvação das almas bondosas e, acima de tudo, cristãs: "pregar era, de fato, definir os contornos da verdadeira religião diante da heresia e da superstição" (BEAULIEU, 2006, p.367). Por meio de grandes conflitos entre numerosas ideias mitológicas ela se estabelece no Ocidente como uma referência religiosa e passa a aumentar seu território religioso por meio de seu discurso e de suas estratégias de profissão: "as armas da Igreja eram mais espirituais" (LE GOFF, 2005, p.275)

O cristianismo se instituiu como explicação para a vida, para a conduta humana e para a morte. O discurso religioso caracteriza-se pela ideia do pós-morte, do supremo e do sobrenatural. Na Idade Média o medo do desconhecido estava presente no cotidiano, o homem medieval reagia aos conflitos e as dificuldades por meio de sua fé, muitas vezes conflituosa entre o desconhecido e a ideia cristã. Esse imaginário medieval confundia-se com as diversas mitologias antigas e a busca por novas explicações.

1 Daniel Lula Costa é Mestrando em História pelo Programa de Pós-graduação em História da Universidade Estadual de Maringá (PPH-UEM). Bolsista da CAPES. Integrante do Laboratório de Estudos em Religiões e Religiosidades (LERR-UEM). E-mail:daniellcosta23@yahoo.com.br

2 Solange Ramos de Andrade é Professora Associada do Departamento de História e do Programa de Pós-Graduação em História da Universidade Estadual de Maringá - PR. Bolsista Produtividade em Pesquisa pela Fundação Araucária de Apoio ao Desenvolvimento Científico e Tecnológico do Estado do Paraná. Coordenadora do Laboratório de Estudos em Religiões e Religiosidades (LERR-UEM). E-mail: sramosdeandrade@gmail.com 
O Além foi o tema de maior repercussão no medievo, saber a trajetória da alma após a morte é uma ideia confortante e interessante. "O além é um dos grandes horizontes das religiões e das sociedades. A vida do crente transforma-se quando ele pensa que nem tudo fica perdido com a morte." (LE GOFF, 1981, p.15)

A própria estrutura das cidades estava ligada à mentalidade da relação entre o vivo e o morto. Os cemitérios estavam mais próximos do solo sagrado, ao lado das Igrejas e os rituais como a preparação do corpo para ser enterrado e a confissão antes da morte mostram a extrema influência do cristianismo no imaginário ocidental. Estas formas de conduta estão ligadas a preocupação do vivo com a sua alma e com o seu destino após a morte, "O quadro de todas essas práticas é a comunidade local dos vivos e dos mortos, a paróquia, o par indissociável da igreja e do cemitério no próprio centro da aldeia ou do bairro." (SCHMITT, 1999, p.145)

De certa forma o próprio conhecimento do pós-morte não era em seu todo confortante. Do ano mil ao século XIII, um dos ambientes descritos no medievo caracterizou-se pelo medo, pela punição, pelo pecado, pelos seres monstruosos e pelo Diabo. Este ambiente foi muito citado no medievo e ficou conhecido como Inferno. Dos três ambientes do pós-morte cristão (Inferno, Purgatório e Paraíso) este foi o que mais marcou o imaginário e a conduta do fiel, pois uma de suas caracteristicas era estabelecer a punição pelo ato do pecado. Ao conhecer a punição e o mal que habitava este local o cristão buscava levar uma vida de paz e bondade.

Terrificantes ou tranqüilos, a morte e os mortos estão igualmente presentes muito concretamente em um grande número de relatos para dar esperança (mostrando, com o apoio de exemplos, que até o último suspiro nunca é tarde demais para arrepender-se dos pecados) ou para despertar o medo (descrevendo com grande luxo de detalhes os castigos infernais). (SCHMITT, 1999, p.144)

Dessa forma nos deparamos neste momento com as seguintes perguntas: Quem é o Diabo? Como ele é descrito? Por meio destas perguntas reconstruiremos este ser de acordo com algumas das diversas imagens e discursos que relatavam ou descreviam o Diabo como rei do reino do mal absoluto cristão, principalmente buscando entender a representação do Diabo na obra magna de Dante Alighieri: a Divina Comédia. 
Antes de conhecermos o Diabo dantesco devemos entender alguns empecilhos como: o mito de origem do reino do mal cristão, as imagens de Lúcifer que foram pensadas e como seu mito foi construído. A existência do Inferno é resultado de um conflito celestial, de acordo com a mitologia cristã, um dos anjos de Deus rebelou-se contra seu Senhor com o desejo de ser como seu criador ou até mesmo melhor que ele. Ao descobrir está ideia recorrente na mente de um de seus anjos, Deus acaba punindo-o, e também aqueles que o apoiaram.

Estava presente no imaginário medieval que do Paraíso celestial o anjo foi lançado à Terra, sua queda foi tão forte que modificou a própria geografia do planeta. De acordo com está interpretação o Inferno é criado como um grande buraco em formato de cone que se prolonga até o centro da Terra, onde está o anjo caído, conhecido também como Lúcifer.

Lúcifer é um dos nomes dados a personificação do mal na religião cristã. Não se sabe ao certo a própria origem deste nome, alguns historiadores atribuem a esta denominação uma interpretação do livro de Isaías. Na realidade o termo Lúcifer não seria um nome, mas um adjetivo que significa: "o que leva a luz" (LINK, 1998). Ao analisarmos o próprio contexto desta afirmação, contida no livro de Isaías, notamos que o termo poderia ter qualificado a estrela Vênus, uma das primeiras a aparecer ao anoitecer; e que Isaías teria utilizado está palavra para se referir a um rei tirânico que havia caído (LINK, 1998).

No século XIII, ao escrever a Divina Comédia, o poeta florentino, Dante Alighieri, denomina o ser maligno do Inferno como Lúcifer, ou seja, para o poeta a denominação Lúcifer e Diabo são atribuídas ao mesmo ser (LINK, 1998), consequentemente, significam a mesma coisa. Mas como isso acontece?

A atribuição das ações malignas e de tudo aquilo que é tido como mal são tidas como obras do Diabo, ou seja, podemos deduzir que o Diabo é o próprio mal. As denominações Diabo e Lúcifer referindo-se ao ser maligno não estão nas Escrituras (LINK, 1998). No entanto devemos investigar a apropriação deste termo pelo cristianismo e pelos fiéis para que, posteriormente, significasse a personificação do mal.

O Diabo possui inúmeros nomes, estes vão de Satã, Demônio, Rei do Inferno, até chegar a Lúcifer. Como observamos, o termo Diabo não 
está presente no Antigo Testamento, portanto, como o próprio Link descreve: "fora introduzido pelos judeus alexandrinos: ao verterem o Antigo Testamento para o grego, traduziram o satan hebraico para o grego diabolos." (LINK, 1998, p.24). A palavra Diabo provém de três línguas diferentes: hebreu, grego e latim, sendo respectivamente; satan, diabolos, diabolus.

O Antigo Testamento, mais precisamente, o Livro de Jó contribuiu para a história do Diabo e, também para a atribuição da associação angelical que a ele será atribuída na arte do século IX. "Deus está satisfeito com seu servo Jó e o louva, mas eis que se adianta o Satan (= 'hostilizar, acusar, caluniar'), um dos 'filhos de Deus', isto é, um anjo." (NOGUEIRA, 1986, p.8)

Mas o que significa Diabo? De acordo com a maioria dos dicionários de figuras simbólicas, o termo Diabo significa: caluniador, provocador de discórdia, acusador. Averiguamos o significado da palavra Diabo em dois dicionários de símbolos. De acordo com Udo Becker, o termo Diabo significa:

[gr. Diabolos= caluniador, provocador de discórdia; hebr. Satã]. Segundo a doutrina cristã, trata-se de $>$ anjos que se rebelaram contra Deus, especialmente o mais elevado entre eles, Lúcifer, que seduziu o primeiro casal humano ao pecado desde então é o "príncipe do mundo". (BECKER, 2007, p.88)

Já, de acordo com o Chevalier e Gheerbrant Diabo significa:

El maligno es el símbolo de lo malvado. Vistase de gran señor o gesticule sobre los capiteles de las catedrales, tenga cabeza de boque o de camello, los pies ahorquillados, cuernos, pelo por todo el cuerpo, poco importan las figuras, él no anda nunca escaso de apariencias, pero es siempre el Tentador y el Verdugo. (CHEVALIER; GHEERBRANT, 1986, p.414, negrito nosso)

Notamos que o primeiro dicionário busca a explicação na própria etimologia da palavra, enquanto o segundo analisa o próprio termo produzido pelo imaginário, sendo ambos por este motivo necessários. Esta 
breve explicação nos mostrou as várias denominações do Diabo, mas qual seria a sua forma?

De acordo com Link, o Diabo é uma máscara sem rosto (LINK, 1998); título que ele atribuiu a seu livro. A explicação é que diferente das figuras cristãs como, por exemplo, Jesus Cristo e Maria, o Diabo não possui uma imagem estabelecida e institucionalmente aceita. Dessa maneira o termo e o próprio imaginário carregam inúmeros modelos do que seria a figura fisica de Lúcifer. Perante os séculos notamos uma imagem do Diabo muito variável, ela passa por diversas metamorfoses, de uma figura angelical para a de um monstro grotesco.

A própria associação de Deus como luz, brilhante e iluminado possibilita uma contraposição do Diabo, seu maior adversário, como representante da escuridão, do preto e obscuro. Lúcifer é o adversário de Deus e, portanto, é tudo aquilo que é oposto a Deus, de acordo com Chevalier e Gheerbrant, o Diabo é: "centro de noche, por oposición a Dios, centro de luz.” (CHEVALIER; GHEERBRANT, 1986, p.414). No século IX, Lúcifer passa a ser representado como um anjo negro, escuro e nu.

Por que o Diabo é preto? Seu negrume contrastava com a beleza branca dos anjos. O preto representa o mal e a poluição. Satã sentado em seu trono no Inferno é sempre preto. Quando cai do céu, é preto o mais das vezes. Talvez o negrume do Diabo tenha relação com os deuses egípcios e núbios. (LINK, 1998, p.63, negrito nosso)

$\mathrm{Na}$ maioria das vezes o Diabo é representado como um anjo nu e pintado em tinta preta. A nudez pode ser tanto uma representação da tentação ou a ideia de um ser não social, ou seja, que não vive mais em sociedade desde a sua expulsão do Paraíso celestial. "Nudez tornou-se desnudamento, e desnudamento tornou-se degradação e humilhação, um sinal de ser enxotado como um louco ou um animal [...]" (LINK, 1998, p.67).

O Diabo não era representado de forma homogênea pelos pintores e escritores, eles não sabiam como construir ou encarar o anjo caído. Muitas pinturas anteriores ao século XVI colocam o Diabo em comparação com o Deus Pã; um sátiro metade homem e metade animal, com cascos, chifres, orelhas pontudas e barda. Não se sabe o porque os sátiros e o próprio Deus Pã foram transformados em demônios e, muitas vezes, no próprio Diabo. 
Constatamos que a figura do Diabo passou por diversas transformações que culminaram em diversas associações ao mal, ao grotesco e aos seres mitológicos. Estas intenções de entender o Rei do Inferno, pertencentes às diversas obras de arte do período medieval, à literatura e ao discurso cristão possibilitaram que o poeta florentino Dante Alighieri construísse outra versão do Diabo cristão; verificaremos a forma e a representação deste monstro na Divina Comédia.

\section{O Lúcifer dantesco}

O Diabo, como vimos, possui diversos nomes e isto também ocorre na obra de Dante, na qual encontramos a nomenclatura: Dite, Lúcifer e Satã. Este ser possui características grotescas, medonhas e monstruosas, mas antes de verificarmos a personificação do Diabo na Divina Comédia faz-se necessário uma breve apresentação do poeta, Dante Alighieri e de sua obra magna.

O poeta florentino nasceu na cidade de Florença em 1265 (FRANCO JUNIOR, 2000). Não possuímos grandes informações sobre a sua infância e adolescência, mas perante algumas biografias do poeta e de acordo com as suas obras, verificamos que ele frequentou instituições de ensino e dedicou-se ao conhecimento. Dante foi um poeta preocupado com o seu mundo e com a sua cidade natal, mas acima de tudo ele amou Beatriz.

O poeta conheceu Beatriz aos nove anos de idade, e apaixonouse. Não sabemos ao certo se Dante encontrou-se muito com a dama, pois foi obrigado a casar-se com Gema Donatti por meio de um acordo matrimonial (DISTANTE, 2008). Dessa forma o amor de Dante por Beatriz não passou de um sentimento reprimido. Beatriz morreu em 1290 (FRANCO JUNIOR, 2000), e o amor entre ela e o poeta não foi concretizado.

Por meio de desentendimentos políticos, Dante Alighieri foi exilado de sua cidade natal. Foi durante este exílio que ele dedicou-se integralmente a poesia, e escreveu sua obra magna Divina Comédia. O objetivo central deste poema é possibilitar que Dante reencontre seu grande amor, Beatriz. Como eles não puderam ser felizes em suas vidas terrenas, Dante pensou em amá-la na vida após a morte. Dessa forma o protagonista de sua obra é 
ele mesmo, ainda vivo que peregrinará pelos ambientes do pós-morte cristão para encontrar a alma de Beatriz que foi destinada ao Paraíso celestial.

O poema é dividido em três partes: o Inferno, o Purgatório e o Paraíso. Cada uma delas possui 33 cantos, com exceção do Inferno que possui 34, sendo que o primeiro é uma introdução para toda a obra. As estrofes são compostas por três versos, em tercetos encadeados (DISTANTE, 2008). O número três é muito presente na estrutura do poema; uma referência a Santíssima Trindade: Pai, Filho e Espírito Santo.

Para cumprirmos com o nosso objetivo focaremos na primeira parte do poema, o Inferno. Ele é dividido em nove círculos infernais, cada qual diferenciado pelas punições, pelos pecados, pelos demônios e pela estrutura ambiental. O poeta organizou e criou uma geografia para o Inferno cristão, conforme lemos o poema conseguimos pensar imageticamente como Dante e o imaginário medieval conceberam o Inferno cristão.

Ainda segundo este imaginário, o Inferno originou-se próximo a cidade de Jerusalém. A queda de Lúcifer deu forma ao ambiente e o estruturou em círculos. O primeiro círculo é o Limbo, daqueles que não foram batizados ou nasceram antes de Cristo. O segundo círculo é o dos luxuriosos; no terceiro estão os gulosos; no quarto círculo estão os avaros e pródigos; no quinto encontramos os danados pela ira; no sexto círculo estão os hereges; no sétimo os violentos; no oitavo os fraudulentos; no nono e último círculo, os traidores.

A figura central para nossa análise encontra-se no nono círculo do Inferno, o círculo dos traidores e também, o último círculo, onde o peso da alma ganha o seu ápice, pois para Dante a traição era o pior dos pecados. Este círculo é localizado no centro da Terra e é dividido em quatro partes: Caina, Antenora, Ptoloméia e Judeca. Este círculo tem uma peculiaridade, ele é frio e seu lago Cocito está congelado, onde estão as almas traidoras. Lúcifer está na última parte onde mastiga os traidores: Judas, Brutus e Cássio.

A própria imagem que Dante transmite de Lúcifer é algo um tanto diferente. Devemos compreender que a partir do ano mil o Diabo estava solto, "O Inimigo e miríades de demônios vagavam por toda parte, tentando e corrompendo, explorando cada fraqueza e desejo" (NOGUEIRA, 1986, p.35). Ao lermos e verificarmos o Diabo na Divina 
Comédia percebemos que a intenção de Dante não é mostrar um ser livre que vaga pelo seu reino assim como anda pela Terra, mas uma figura que em seu lar é presa, medonha e grotesca.

Lúcifer ‘já foi belo como hoje é feio’, lembrou Dante a seus leitores, mas somente a feiúra e maldade de Satã estiveram na mente dos crentes, pensadores, escritores e artistas durante mais de mil anos. Até mesmo Botticelli, amante da beleza, desenhou uma fera repulsiva para ilustrar o Lúcifer de Dante. (LINK, 1998, p.31)

No século XI e XII a arte constrói o Diabo com barba, cascos e pelos, Muchembled (2001) afirma que o Diabo passa a tornar-se bestial a partir do século XIII. A herança das imagens do demoníaco ainda estão presentes e transformam o Diabo em um ser animalesco, grotesco, com unhas grandiosas, uma expressão tenebrosa e dentes horríveis, como o oposto dos anjos.

Ele deixa sua abstração sem forma para tornar-se devorador de homens, uma besta do Apocalipse. As faces de um homem com barba, antes atribuídas ao sátiro, orelhas pontudas e olhar fulminante marcam a figura do Diabo neste período. Ele causa medo às elites da fé e se sobrepõe sobre os cristãos mais simples que antes o viam como uma abstração sem forma e agora vinculam as imagens das catedrais, do teatro e das obras de arte ao modelo de Diabo.

O diabo ainda é buscado, ou melhor, os homens que o imaginam hesitam entre a lição grotesca que agrada a muitos e uma definição mais assustadora nascida de uma meditação teológica desenvolvida desde Gregório, o Grande. A Acentuação de traços negativos e maléficos dos demônios pode ser realmente assinalada a partir do século XIV [...] (MUCHEMBLED, 2001, p.34)

Dante Alighieri descreve a figura de Lúcifer no final do século XIII e início do XIV. A sua interpretação é baseada no monstruoso, na ideia do anjo caído possuidor de asas que não são mais belas e angelicais, mas grossas, negras e em formato igual às asas de morcego. O Lúcifer dantesco é descrito no canto 34, último canto do Inferno, Dante apresenta primeiramente as faces do Diabo: 
Mas foi o meu assombro inda crescente

quando três caras vi na sua cabeça:

toda vermelha era a que tinha à frente,

e das duas outras, cada qual egressa

do meio do ombro, que em cima se ajeita

de cada lado e junta-se com essa,

branco-amarelo era a cor da direita

e, a da esquerda, a daquela gente estranha

que chega de onde o Nilo ao vale deita.

(ALIGHIERI, 2008, p.226)

Nesta descrição, Lúcifer possui três faces e cada uma delas difere-se pela cor. A do meio é vermelha, a da esquerda é negra e a da direita é branco-amarelada. Diversos historiadores buscam explicações para a distribuição de cores das faces do Diabo dantesco, mas as suas interpretações ainda são incertas. De acordo com Russel (2003), diversas são as teorias sobre as cores aqui analisadas e uma delas foi a de Freccero que as analisou da seguinte forma:

Ele começa a explicação com Lucas 17:6, no qual Cristo diz que com fé profunda o bastante a pessoa poderia pedir para uma amoreira se mover e ela se moveria. Santo Ambrósio usou a amoreira como um símbolo do Diabo, pois da mesma maneira que sua fruta começa branca, amadurece e fica vermelha, e então fica preta, assim o Diabo começa glorioso e branco, brilha vermelho no poder dele, e então fica preto com o pecado. Mas Agostinho usou a amora tricolorida como um símbolo da cruz. E Ubertino de Casale descreveu vexilla de Cristo como colorido da mesma maneira. O que Dante fez foi reunir a cruz, o Diabo e as três cores. (RUSSEL, 2003, p.224)

Depois de descrever a cabeça de Lúcifer, Dante descreve o seu corpo bestial. Podemos identificar a figura de um anjo caído, o Diabo dantesco é possuidor de três pares de asas de morcego em comparação as asas dos Serafins que no Paraíso dantesco possuem três asas brancas e grandiosas; o branco e iluminado em oposição ao escuro e macabro. Segundo Link 
(1998), a atribuição de asas de morcego ao Diabo não é algo originado em Dante, algumas teorias apontam que ele pode ter se baseado nas pinturas das catedrais, principalmente na pintura de Giotto que desenhou os demônios com asas de morcego.

$$
\begin{aligned}
& \text { Um par de grandes asas acompanha } \\
& \text { cada uma, com tal ave consoantes: } \\
& \text { - vela de mar vira eu jamais tamanha- } \\
& \text { essas, sem penas, semelhavam antes } \\
& \text { às dos morcegos, e ele as abanava, } \\
& \text { assim que, co' os três ventos resultantes, } \\
& \text { as águas de Cocito congelava. } \\
& \text { (ALIGHIERI, 2008, p.227 ) }
\end{aligned}
$$

O Lúcifer dantesco é um monstro grandioso, com três faces que diferem-se não só pelas cores, mas pelos danados que mastiga. Em cada uma das bocas são mastigados os pecadores: Judas, Brutus e Cássio. Dante narra está cena de uma maneira que provoca no leitor a sensação de horror e desgosto, algo repugnante e bestial. Além das faces e dos pares de asas, Dante apresenta a bestialidade do Diabo cobrindo seu corpo grandioso com pelos.

$$
\begin{aligned}
& \text { Ao chegarmos à altura da junção } \\
& \text { da coxa ao tronco do gigante averno, } \\
& \text { meu guia, dando sinais já de exaustão, } \\
& \text { reverteu o corpo, sem perder governo } \\
& \text { do pelame, e seguiu, ora subindo, } \\
& \text { dando-me o senso de voltar pro inferno. }
\end{aligned}
$$$$
\text { (ALIGHIERI, 2008, p.228) }
$$

O corpo felpudo e as suas asas são uma demonstração das figuras bestiais e do desconhecido, uma associação das características animalescas ao Diabo. O Rei do Inferno é apresentado de diversas formas e não carrega uma representação ideal sendo muitas vezes o oposto daquilo que é tido como bom pela religião cristã. O Diabo da Divina Comédia reina no Inferno e carrega o peso de todos os pecados, sendo por isso a ponta do cone invertido deste ambiente. Ele é grotesco e animalesco, a sua queda do Paraíso celestial o deformou: 
Dante pretendeu apresentar Lúcifer vazio, tolo, e desprezível, um contraste fútil para a energia de Deus. Dante viu o mal como negação e teria pensado o Diabo de Milton muito mais ativo e efetivo. A ausência formal de Lúcifer de grandes áreas da Comédia e do próprio Inferno indica o acorde de Dante com a teologia escolástica, limitando o papel do Diabo. (RUSSEL, 2003, p.217)

O Diabo passa a ser transformado na besta primordial, não apenas na besta física retratada na literatura e na arte, mas também na besta que produz atos monstruosos e animalescos, atos que todo ser humano teria de evitar para não deixar que o próprio Diabo o possuísse. Dessa forma a besta passa a ser considerada um animal possuído pelo demônio, cujas ações seriam conduzidas para a anarquia, matança e carnificina, o mais longe possível da luz e de Deus. O lobisomem e todos os outros seres que aterrorizavam as civilizações passam a ser considerados servos do Diabo, sendo ele retrato dessa maneira, com rabo, pêlos, garras, cauda, asas e cuspidor de fogo, muitas vezes confundido ou idealizado como um dragão (MUCHEMBLED, 2001).

O Lúcifer dantesco é apresentado de uma forma medonha, monstruosa, grotesca e horrorosa, uma oposição ao belo, à luz, ao Cristo, aos anjos e a Deus. A partir do século XIII e início do XIV, o Diabo é associado às bestas, ele passa de um ser meio humano com características animalescas para se constituir na própria imagem do monstro e do desconhecido que gera e transmite medo da mesma forma que é grotesco e medonho. 


\section{Bibliografia}

ALIGHIERI, D. A Divina Comédia: Inferno. 1ª Edição (1998). Prefácio por Carmelo Distante, tradução e notas por Italo Eugenio Mauro. Edição bilíngue. 15ª Ed. São Paulo: Editora 34, 2008.

BEAULIEU, M. P. Pregação. In: LE GOFF, J; SCHMITT, J. Dicionário temático do ocidente medieval. São Paulo: EDUSC, 2006. p.367-376.

BECKER, U. Dicionário de Símbolos. São Paulo: Paulus, 2007.

CHEVAlIER, J; GHEERBRANT. Diccionario de los Símbolos. Barcelona: Editorial Herder, 1986.

DistAnTE, C. Prefácio. In: ALIGHIERI, D. A Divina Comédia: Inferno. São Paulo: Editora 34, 2008. p. 7-17.

FRANCO JUNIOR. H. Dante: o poeta do absoluto. São Paulo: Ateliê Editorial, 2000

LE GOFF, J. A Civilização do Ocidente Medieval. São Paulo: Edusc, 2005

LE GOFF, J. O nascimento do purgatório. Lisboa: Estampa, 1981.

LINK, L. O Diabo: A máscara sem rosto. São Paulo: Companhia das Letras, 1998.

MUCHEMBLED, R. Uma história do Diabo: séculos XII-XX. Rio de Janeiro: Bom Texto, 2001.

NOGUEIRA, C.R.F. O Diabo no imaginário cristão. São Paulo: Editora Ática, 1986.

RUSSEL, J. B. Lúcifer: O Diabo na Idade Média. São Paulo: Editora Madras, 2003.

SCHMITT, J. C. Os vivos e os mortos na sociedade medieval. São Paulo: Companhia das Letras, 1999.

\section{Imagem:}

Um Diabo Lógico, Salvador Dalí. Disponível em http://extra.globo. com/incoming/5661795-dec-76d/w448h673-PROP/dali-divina-comedia. jpg, consultado em 07/10/2012. 


\section{Demoniologia de Eça de Queiroz no conto O Senhor Diabo}

Davi da Silva Oliveira ${ }^{1}$

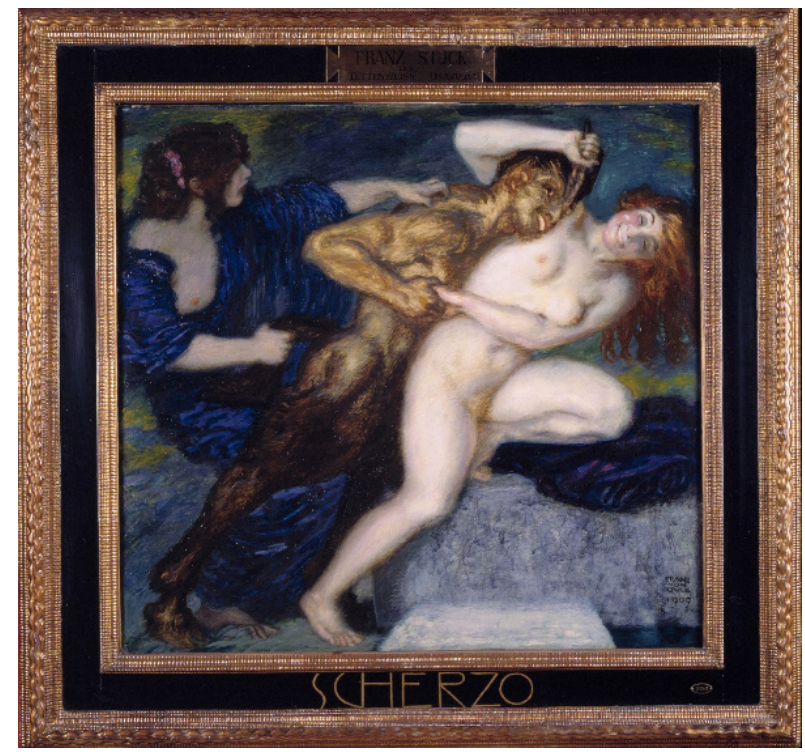

\section{Diabo histórico}

Um breve histórico das manifestações demoníacas através da história já nos traz um panorama sobre as dissimulações materializadas pelo Diabo. De acordo com Cousté, (1997, p. 112-113), o Maligno caminhava com

1 Mestre em Literatura e Crítica Literária pela PUC-SP, professor de Literatura Brasileira e Portuguesa no UNASP, Campus Engenheiro Coelho (SP). Email: davi.oliveira@uasp. edu.br 
a humanidade desde a Pré-História, quando se praticava o exorcismo e ritos com sacrificios. No entanto, os registros na crença e no medo em um deus do mal surgem a partir da Idade Média.

Os mesopotâmios atribuíam grande importância à divindade do mundo. Sataran, o deus-serpente, era o mito central. Ele e seus demônios como Namtaru, responsável pelas pestes e catástrofes; Rabisu, aquele aparecia imprevisivelmente para perturbar a vida dos homens; e Labasu, um ser ladrão. Todos eles atuavam como promotores de desgraças dos seres humanos.

A personagem demoníaca mais fascinante, na Mesopotâmia, após receber influências de outros povos, chama-se Lilith. De acordo com Cousté (1997, p. 116), Lilith:

Era o terror dos que se achavam entregues ao sono; obtinha deles o sêmen de que necessitava para engendrar monstros. Tais aberrações que povoavam de ciladas o dia e a noite sumerianas apresentavamse no leito de morte de seu desditoso pai e tornavam atrozes as horas de agonia.

Singular é este fato, pois é a primeira vez em que o Mal vem materializado numa divindade feminina. Ainda de acordo com Cousté (ibiden), os talmudistas acreditam que, perdendo Lúcifer a batalha para Adão, o Mal se personifica como Lilith.

Para os egípcios, (3.000 a. C), sob o nome de Seth, o Diabo, segundo (OLIVEIRA, 2011, p. 171) "era ameaça do deserto, a seca, a fome e a morte". Em consórcio com Seth, demônios femininos como Nut (vaca celeste), Pax het e Tef net (diabinhas felinas) também atuavam no meio da população.

Ainda na esteira de Cousté (1997, p. 123) o mundo ocidental recebeu a influência do povo persa com crença baseada no dualismo Bem/ Mal, por meio do masdeísmo. O masdeísmo apregoa que há um princípio indeterminado denominado de Ahuramazda (Deus/Zerman/Temp no sentido de eternidade) que dá origem a dois demiurgos complementares, Ormuz (infinito para o alto) e Arimã (infinito para baixo).

Na Idade Média, portanto, segundo Brandão (2003, p. 157), “(...) a imagem do Diabo se cristalizou no imaginário do Ocidente. 
Corroborando com esta declaração, (NOGUEIRA, 2000, p. 74), assevera que:

(...) o Diabo odeia a Deus e por conseqüência o homem, feito a Sua imagem e semelhança, fora fortemente difundido e, com isso, a crença de que o Mal estava longe de ser vencido. Assim, o Diabo e seus servos estavam por toda a parte tentando corromper homens de modo afastá-los de Deus.

\section{Diabo no cordel}

Relevante é a presença do Diabo na literatura de Cordel, na qual o ser do mal se traveste como conquistador de mulheres, negociante, avarento, gerente do inferno (com livro-ponto, mercadorias e controle de fluxo de caixa) e engraçado. Folhetos como Carta de Satanás ao amigo George Busch, de Zé de Madalena, O Satanás reclamando a corrução de hoje em dia (sic), de José Costa Leite reportam à figura do Diabo. Dentre aqueles onde o Diabo adquire notoriedade como personagem, citemos uma estrofe do emblemático folheto $A$ chegada de Lampião no inferno, de José Pacheco:
Lúcifer mais Satanás
Vieram olha do terraço
Tudo contra Lampião
De cacete, faca e braço
E o comerciante no grito
Dizia - Briga bonito,
Negrada chega-lhe o aço!

\section{Diabo bíblico}

Inclinando o olhar sobre o texto das Sagradas Escrituras, encontramos pela primeira vez a designação do nome 'demônio' em Deuteronômio 32:17 a citação: "Sacrifícios ofereceram aos demônios, não a Deus; a deuses que não haviam conhecido, novos deuses recém-chegados, aos quais vossos pais não veneraram." 
Já no livro de Lucas 8:29, portanto, no Novo Testamento, é registrada a presença desta entidade, demônio, nas seguintes palavras: "Pois Jesus tinha ordenado ao espírito imundo que saísse do homem. Já havia muito tempo que se apossava dele, e embora o mantivesse preso com grilhões e cadeias, quebrava as prisões, e era impelido pelo demônio para o deserto."

De posse destas duas referências bíblicas em que se menciona a palavra e os atos do demônio, Davis (1897, p. 153) diz que este termo

Entre os gregos tinha várias significações, podendo ser um deus, ou uma divindade no sentido geral; o gênio ou a fortuna; a alma de alguém que pertenceu à idade de ouro e que agora se transformou em divindade tutelar; um deus de categoria inferior.

Segundo Davis, há uma diferença entre Diabo e demônio no idioma grego. Os demônios se apoderam dos homens maus que são subordinados aos diabos.

Enquanto isso, os judeus materializavam outras noções sobre o assunto tais como: que os demônios eram almas dos maus; que poderiam ser exorcismados por meio de raízes e do nome de Salomão ou até serem expelidos através da fumaça do coração do fígado de peixes queimados.

A palavra Diabo, segundo o próprio Davis (idem, 157) vem do grego diabolos, caluniador. Este substantivo é aplicado aos espíritos maus, conforme encontramos em Marcos 1:34: "e Jesus curou a muitos doentes de diversas enfermidades, e expulsou muitos demônios, porém não permitia que eles falassem, porque o conheciam."

Diabo também é o nome que é aplicado ao maligno Satanás, o maior de todos os anjos caídos (Ap. 12:9). Sobre Diabo-Satanás recaem os mais negativos predicativos tais como: a) o pecado que originou a sua queda foi o orgulho (I Tm 3:6); b) o maior inimigo de Deus e do homem (I Pe 5:8); c) foi ele quem tentou a Jesus e incentivou os homens a pecar (Mt 4:1); d) é a antiga serpente que tentou a Eva (II Cor 11:3); e) é chamado de mentiroso, homicida e pai da mentira (Jo 8:44); f) Quando a boa semente é lançada sobre a terra, o diabo arrebata (Lc 8:12); g) incessantemente, cerca os filhos de Deus como um leão rugidor, procurando a quem possa devorar (I Pe 5:8); h) arma ciladas contras os filhos de Deus (Ef. 6:11); i) é um astucioso enganador (II Cor 11:3); 1) Ele tem poder para se apoderar 
das criaturas (At 10:38); k) fomenta a perseguição dos mártires (Ap. 2:10); m) acusador, "E ouvi uma grande voz no céu, que dizia: Agora é chegada a salvação, e a força, e o reino do nosso Deus, e o poder do seu Cristo; porque já o acusador de nossos irmãos é derrubado, o qual diante do nosso Deus os acusava de dia e de noite" (Ap 12:10). Finalmente, ele será lançado no fogo eterno, feito para ele e seus anjos (Mt 25:41).

$\mathrm{Na}$ esteira das nomenclaturas, Satanás também é conhecido no recinto bíblico desde o terceiro século, especialmente por causa de uma interpretação de Lucas 10:18, que é uma explicação de Isaías 14:12 como Lúcifer - quem tem ou dá luz, "Como caíste do céu, ó estrela da manhã, filha da alva! Como foste lançado por terra, tu que habitavas as nações."

A lista de substantivos aplicados ao Diabo amplia-se quando se associa a ele a imagem da serpente e do dragão, de acordo com Apocalipse 12:9: "E foi precipitado o grande dragão, a antiga serpente, que se chama diabo e Satanás, que engana a todo mundo."

Num processo de genealogia de pecado e pecador, na Bíblia, os pecadores contumazes, os injustos, os mentirosos e os assassinos são metaforicamente denominados de filhos do diabo, de acordo com João 8:44: "Vós pertenceis ao vosso pai, o diabo, e quereis executar o desejo dele. Ele foi homicida desde o princípio, e não se firmou na verdade, pois não há verdade nele. Quando ele profere mentira, fala do que lhe é próprio, pois é mentiroso e pai da mentira."

Mais do que filhos do diabo, Jesus, ao se dirigir a Judas Iscariotes, declarou que este interiorizou o próprio diabo, conforme o relato de João 13:27: "Assim que Judas tomou o pão, entrou nele Satanás. Disselhe Jesus: O que estás prestes a fazer, faze-o depressa."

No livro de Judas, 19, o apóstolo, o escritor bíblico faz referência a uma disputa ocorrida entre o Arcanjo Miguel e o Diabo. Esta disputa é sobre o corpo do Messias: "Mas, o arcanjo Miguel, quando contendia com o Diabo, e disputava a respeito do corpo de Moisés, não ousou pronunciar contra ele juízo de maldição, mas disse: O Senhor te repreenda."

Ao dragão-diabo-satanás-serpente é plasmada a característica física como: aspecto cromático e anatômico, segundo o texto do livro do Apocalipse 12:9: "Viu-se também outro sinal no céu: um grande dragão vermelho, que tinha sete cabeças e dez chifres, e sobre as suas cabeças sete diademas." 


\section{Diabo eclesiástico}

Volvendo o olhar para o mundo eclesiástico, mais precisamente para o padre Antônio Vieira, percebemos a presença do Diabo num dos brilhantes excertos do prodigioso escritor (apud SARTIN, p. 75):

Dizem que quando o diabo caiu do céu, que no ar se fez em pedaços, e que estes pedaços se espalharam em diversas províncias da Europa, onde ficaram os vícios que nelas reinam. Dizem que a cabeça do diabo caiu em Espanha, e [...] suposto que à Espanha lhe coube a cabeça, cuido eu que a parte dela que nos toca ao nosso Portugal é a língua, ao menos o entendem as nações estrangeiras que de mais perto nos tratam.

Neste texto, o Diabo materializa-se alegoricamente, sem a rigidez teológica e mais adequadamente com aspecto pedagógico. Em termos de analogia, desloquemos olhar para o seguinte episódio narrado pelo padre Bernardes (apud DELFINO, p. 76):

Vindo este santo religioso com outras pessoas de tomar Ordens Sacras desde Tortosa para Valença, se lhe juntou no cainho hum moço grande fallador, e muy inquieto, e audaz, o qual chegando a pousada, porfiou, que havia de ficar no mesmo aposento, e cama com o Fr. Domingos. [...] queria o Servo de Deos tomar a necessária refeição do sono, ma elle não deixava com estrondos, e inquietações. Depois começou-se a despir, até a camiza, e a tempo que Fr. Domingos o queria reprehender pela imodéstia, viu que despia também a pelle. Aqui acabou de entender, que era o demônio, e como era costumado a ver semelhantes tramoyas, quis advertir em que parava esta. Lançou o demônio a pelle de remessão sobre huma mesa, e logo esgravatando com hum dedo, tirou hum olho, e depois outro, e com tento, como que receava quebrarem, os acomodou em lugar a parte. Depois desencaixou os dentes, pondo-os em outra parte por sua ordem. Depois foy tirando os músculos, e nervos, e cartilagens, e veyas, 
e finalmente a carne, raspando-a dos ossos com vagarosa curiosidade, e ficou como pintão a morte, e logo de hum fato se foi meter com Fr. Domingos na cama, manchando-lhe os vestidos com sangue, que estava escorrendo. Sentia o servo de Deos na vizinhança de uma tal companhia, huma frieza mais que de neve, mas não se turbou; a força de calor de oração foy desfazendo aquella ossada, ate que desappareceo. (sic).

O religioso Bernardes busca seus suportes literárias na vida dos santos, mais precisamente nas tradições literárias da vida dos santos, local em que o Diabo enfrenta os heróis da Igreja. Segundo Tausiet e Amelang (2004, p. 74), “(...) não se tratam de combates alegóricos, mas [...] de combates reais, fisicos, que com freqüência deixam o santo gravemente ferido."

Em se comparando os dois textos, o de Vieira e o de Bernardes, visivelmente percebe-se a maneira como o ser diabólico se materializa. Como já mencionado antes, em Vieira, o diabo é alegórico, enquanto que neste último episódio narrado pelo padre Bernardes, visualizamos um diabo mais concreto, com presença física, sendo anatomicamente construído, um ser tangível, perceptível pelo contato.

\section{O Diabo Eceano}

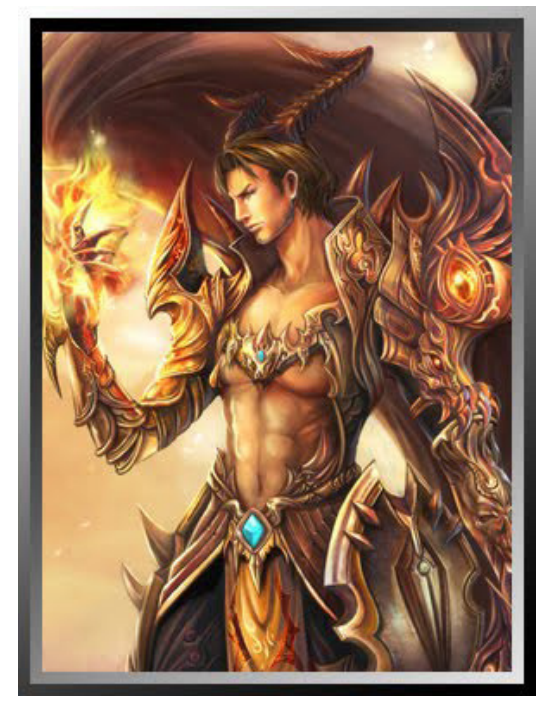


O Diabo como personagem literária na obra de Eça de Queiroz não é privilégio do conto em estudo. Em O Mandarim (p. 29-30, negrito nosso), o escritor faz menção deste ser nas seguintes palavras:

\begin{abstract}
Eu nunca acreditei no Diabo - como nunca acreditei em Deus. Jamais o disse alto, ou o escrevi nas gazetas, para não descontentar os poderes públicos, encarregados de manter o respeito por tais entidades: mas que existem estes dois personagens, velhos com a Substância, rivais bonacheirões, fazendo-se mutuamente pirraças amáveis - um de barbas nevadas e túnica azul, na toilette do anti Jove, habitando os altos luminosos, entre uma corte mais complicada que a de Luís XV; e o outro enfarruscado e manhoso, ornando de cornos, vivendo nas chamas inferiores, numa imitação burguesa do pitoresco Plutão -não acredito. Não, não acredito! Céu e Inferno são concepções sociais para uso da plebe - e eu pertenço à classe média.
\end{abstract}

No conto O Senhor Diabo, após uma ligeira introdução em que o narrador se diz inapto para escrever para Revistas, bem como de falar de literatura, o narrador argumento que conta, esporadicamente, uma história romântica para adormecer senhoras arquiduquesas da Áustria.

Imediatamente à introdução do texto, escrevendo "Diabo" sempre com letra maiúscula, o narrador formula uma indagação: "Conhecem o Diabo?" O próprio narrador se adianta para dizer que não vai contar a história desta personagem, mas que, sabe de cor a trajetória do ente infernal. História esta que é pautada por ser trágica, luminosa, celeste, grotesca e suave. Também diz que o Diabo é a figura mais dramática da História da Alma. A vida do Diabo, segundo o narrador, é a grande aventura do Mal.

Seguem-se alguns predicativos. Segundo o narrador, O Diabo foi o primeiro a ser citado e que foi ele o inventor dos enfeites que enlanguescem a alma e as armas que ensanguentam o corpo. Também se registra que o Diabo é o representante imenso do direito humano. Isto se explica pelo seguinte motivo: ele quer a liberdade, a fecundidade, a força e a lei. Ele é comparado à Pã sinistra, “(...) onde rugem as fundas rebeliões da Natureza". Acrescente-se a estes predicativos, o fato de que ele combate 
o sacerdócio e a virgindade, aconselha a Cristo que viva, e aos místicos que entrem na humanidade.

A lista de predicativos segue assim: é incompreensível, tortura os santos e defende a Igreja. No século XVI é o maior zelador da colheita dos dízimos. É envenenador e estrangulador. É impostor, tirano, vaidoso e traidor. Conspira contra os imperadores da Alemanha; consulta Aristóteles e Santo Agostinho, suplicia Judas e Bruto que apunhalou César. (questões político-eclesiásticas)

Segue o narrador dizendo que o Diabo tem uma "tristeza imensa e doce, o que se explica talvez pelo fato de que esta nostalgia seja por conta da saudade dos Céus."

Sobre um conflito no céu, o narrador comenta que quando o Diabo era novo e os astros the chamavam de Lúcifer, o portador de luz, ele se revolta contra Jeová e comanda uma grande batalha entre as nuvens.

Em seguida, apresenta-se uma lista de personagens bíblicas que foram vítimas do Diabo: Eva foi tentada; Daniel, o profeta, enganado; Jó, apupado; e Sara, torturada. Focando a atuação em Babilônia, o narrador diz que neste local o Diabo foi jogador, palhaço, difamador, libertino e carrasco.

No exílio dos deuses, o Diabo acampa-se com eles nas florestas úmidas da Gália e embarca expedições olímpicas nos navios do imperador Constâncio. Diante dos olhos de Jesus, tem medo e vai torturar os monges do Ocidente.

Ironicamente, o Diabo escarnecia de S. Macário, cantava salmos na igreja de Alexandria, oferecia ramos de cravos a Santa Pelágia, roubava as galinhas do abade de Cluny, espicaçava os olhos de S. Sulpício e à noite ia, cansado e empoeirado, bater portaria do convento dos dominicanos em Florença e ia dormir na cela de Savonarola.

Teologicamente, o Diabo estudava o hebreu, discutia com Lutero, anotava glosas para Calvino, lia atentamente a Bíblia e ia ao anoitecer para as encruzilhadas da Alemanha jogar com os frades mendicantes, sentados na relva, sobre a sela do seu cavalo. Intentava processos contra a Virgem; era o pontífice da missa negra, depois de ter inspirado os juízes de Sócrates. Sobre este, que nos seus velhos dias havia discutido com Átila sobre os planos de batalha, entregou-se ao pecado da gula. 
$\mathrm{Na}$ lista de argumentos sobre o Diabo, algumas personagens retribuem-lhe algumas ações: Rebelais apupou-o ao vê-lo fatigado, engelhado, calvo, gordo e sonolento; Weir escreve contra ele panfletos sanguinolentos; Voltaire criva-o de epigramas.

Pela primeira vez o narrador apresenta reações do Diabo: O Diabo sorri e olha os calvários do deserto ao redor de si, escreve memória e num dia enevoado, depois de ter dito adeus aos seus velhos camaradas, os astros, morre enfastiado e silencioso. Nesta ocasião, Ceranger escrevelhe um epitáfio.

Eça elabora um dossiê de personagens da história e da literatura que mencionaram a presença e a característica do Diabo, desde as trágicas até às cômicas. $\mathrm{O}$ próprio narrador afirma, em um parágrafo isolado, dedicado a esta declaração: "O Diabo amou muito".

Tudo o que narrador revela parece nada representar, porque ele declara uma frase, começando com a adversativa "mas", "eu quero só contar a história de um amor infeliz do Diabo, nas terras do Norte.", mais precisamente, na Alemanha.

O narrador anuncia que vai contar a história de um amor infeliz do Diabo.

No conto, narra-se um episódio numa casa de pau, onde havia um Jesus de marfim, tendo como personagem Maria - clara, loura e santa -, que fiava constantemente, filha de um velho gordo, vaidoso, sonolento e mau, que bebia cerveja de Heidelberg, vinhos da Itália e cidras da Dinamarca. A outra personagem, de cor branca, um lindo moço, Jusel, delicado, melodioso, santo e tímido, que se encostava a um pilar em frente à casa de Maria.

A dinâmica da pequena cidade é marcada pelo rosnar das aves, o cantar dos peregrinos nas estradas, pelos santos que liam nos seus nichos, e, ele, o Diabo, aliás, os diabos, escarneciam na grimpa das igrejas. O Diabo sempre se apresenta onde o "clima" é tranquilo e sereno.

O narrador, após caracterizar a paisagem e o comportamento de Maria e Jusel, irrompe com uma poesia. É uma poesia de declaração proferida por Jusel para Maria. A história do relacionamento entre Maria e Jusel tem um final feliz para os dois, apesar da tentativa de cisão provocada pelo pai da noiva. 
No texto, o aparecimento do Diabo é marcado por intercalar-se em momentos de paz e romantismo para o casal Maria e Jusel. Já no segundo parágrafo, o narrador apresenta o currículo do Diabo. A lista de peripécias e predicativos vai até o momento em que o narrador anuncia que vai contar a história de um amor infeliz do Diabo.

A história do amor feliz, para Mara e Jusel, e infeliz para o Diabo, segue o seu percurso normal, quando o narrador diz que os diabos escarneciam na grimpa das igrejas. Apesar dos escárnios, as descrições amorosas prosseguem incrustadas por uma poesia encomiosa à Maria.

Mais uma vez o Diabo surge, sendo descrito como tendo uma palidez de mármore, a testa triste e serena como a dos que têm saudade imortal da pátria perdida. Além do mais, o ser do Mal esboça umas risadas frias e metálicas. Neste ínterim, o Diabo diz que é a sua dama que ali está para casar, referindo-se à Maria.

O Diabo até sugere ao seu pajem, Rabil, estragar aquela paixão, pois isto seria uma farsa bem feita ao Compadre lá de cima dos sóis. Jusel diz que a sua força está no Jesus posto na varanda.

A cena de romantismo desenrola-se entre o casal, atingindo o grau maior quando o apaixonado noivo grava no peito de Jesus as inicias J. M. Isto materializa a cerimônia do noivado. Seguem-se a este episódio declarações amorosas responsivas entre Maria e Jusel, Até que o Diabo pede ao pai de Maria que raspe a inscrição gravada no peito do Cristo. O pai de Maria esboça ser possuído ou incentivado pelo Diabo. Maria dirigi-se ao seu genitor, conscientizando-lhe que Jusel é o esposo dela.

Finalmente, o pai de Maria pergunta em tom de grito: Quem é ele? A resposta imediata vem do pajem: É o senhor Diabo. Então, revela-se que o Diabo gostava daquela rapariga, o que explicaria toda a ira do ser do Mal contra a efetivação do relacionamento. Decepcionado com o ocorrido, o Diabo bate em retirada dizendo que vai para o meio da Natureza.

\section{Demoniologia queirosiana}

As aparições do Diabo no texto de Eça assemelham-se ao que encontramos em Jó 1:6, onde se relata que “(...) os filhos de Deus vieram apresentar-se perante o Senhor, e veio também Satanás entre eles.” Aqui 
em Jó a visita de Satanás em meio a um passeio bem que explica o oportunismo do ser do Mal se apresentando diante de ocasiões de estabelecida tranquilidade. Em Jó era um momento feliz, em Eça, o tempo era de uma das festas mais desejadas do mundo: o casamento.

Outro episódio bíblico que se coaduna com o relato queirosiano é o da retirada do Diabo diante de sua derrota. Em Mateus 4:1-11, texto conhecido com "A tentação de Jesus", o Diabo, após três tentativas fracassadas de ludibriar o filho de Deus, finalmente perde seu espaço. O texto diz: "Então, o diabo o deixou, (...)."

O Diabo no conto de Eça de Queiroz é semelhante ao Diabo em padre Bernardes (apud DELFINO, p. 76), ou seja, um diabo concreto, com presença física, sendo anatomicamente construído, um ser tangível, perceptível pelo contato.

Eça prova, pelo episódio narrado, que o Diabo é mesmo aquele que foi mencionado no início do texto: impostor tirano, vaidoso, traidor, conspirador, tentador, enganador, carrasco, acusador e até mesmo poeta. Estes predicativos são basicamente os mesmos largamente apontados pelos escritores bíblicos à figura de Satanás.

$\mathrm{Na}$ demoniologia queirosiana, neste conto, um dos objetivos é caracterizar o Diabo como um destruidor de relacionamentos. Corrobora com esta ideia (NOGUEIRA, 2000, p. 74), asseverando que: “(...) o Diabo odeia a Deus e por consequência o homem, feito a Sua imagem e semelhança (...)". 


\section{Bibliografia}

A BÍBLIA sagrada. 2 ed. Trad. João Ferreira de Almeida. São Paulo: Sociedade Bíblica do Brasil, 1993.

BARCELLOS, José Carlos. Literatura e teologia: aproximações. In JORGE, Silvio Renato (org.). Literatura de Abril e outros estudos. Niterói, RJ: EdUFF, 2002, p. 89-108.

BARROSO, G. Lendas do diabo: ao som da viola. P. 574-579. Disponível em: HTTP://www.jangadabrasil.com.br/agosto60/im60080a.htm acesso em 25 jul.2010.

BETH, Brait. A personagem. 6 ed. São Paulo: Ática, 1998.

BRUNEL, Pierre (org.). Dicionário de mitos literários. 2 ed. Rio de Janeiro: José Olympio, 1998.

CANDIDO, A. et al. A personagem de ficção. 10 ed. São Paulo: Perspectiva, 2007.

CASCUDO, L. C. Antologia do folclore brasileiro, v. 1, 8 ed. São Paulo: Global, 2002.

CLARK, Stuart. Pensando com demônio. São Paulo: EDUSP, 2006.

COHN, Normam. Europe's inner demons. Chigago: University of Chicago Press, 2002.

COUSTÉ, A. Biografia do diabo. O diabo como a sombra de Deus na história. trad. Luca Albuquerque. 2 ed. Rio de Janeiro: Record; Rosa dos Tempos, 1997, p. 249.

DA CAL, Ernesto Guerra. Língua e estilo de Eça de Queiroz. Rio de Janeiro: Edições Tempo Brasileiro: 1969.

DAVIS, John D. Dicionário da Bíblia. Trad. Ver. J. R. Carvalho Braga. 14 ed. Rio de Janeiro. Junta de Educação Religiosa e Publicações, 1987.

ELIADE, Mircea. Ocultismo, bruxaria e correntes culturais. Belo Horizonte: Circulo do Livro, 1977. 
FERRAZ, Salma. Pólen do divino: textos de teologia e literatura.

Blumenau: Edifurb; Florianópolis: FAPESC, 20011.

GABEL, John B; WHEELER, Charles B. A Bíblia como literatura. São Paulo: Edições Loyola, 1993.

GABEL, John B; WHEELER, Charles B. A Bíblia como literatura. São Paulo: Edições Loyola, 1993.

GANCHO, Cândida Vilares. Como analisar narrativas. 8 ed. São Paulo: Ática, 2004.

GOTLIB, Nádia Batella. Teoria do conto. 9 ed. São Paulo: Ática, 1999.

LINK, Luther. Diabo: a máscara sem rosto. São Paulo: Companhia das letras, 1998.

MASINA, Léa. 100 autores que você precisa ler. Porto Alegre: L\&PM, 2009.

MATOS, A. Campos. Dicionário de citações de Eça de Queiroz. Lisboa: Livros Horizonte, 2006.

Sobre Eça de Queiroz. Lisboa: Livros Horizontes, 2002.

MOISÉS, Massaud. A literatura portuguesa. 32 ed. São Paulo: Cultrix, 2007.

A literatura portuguesa através de textos. 28 ed. São Paulo:

Cultrix, 2009.

MESSADIÉ, C. R. F. O diabo no imaginário cristão. Bauru, SP;

EDUSC, 2000, p. 74.

MINÉ, Elza. Eça de Queirós jornalista. Lisboa: Livros Horizontes, 1986.

MINOIS, Georges. História do riso e do escárnio. Tradução Maria

Helena Ortiz Assumpção. São Paulo: Ed. Da UNESP, 2003.

MUCHEMBLED, Carlos Roberto Figueiredo. O diabo no imaginário cristão. Bauru, SP: EDUSC, 2000.

NOGUEIRA, Carlos Roberto F. O diabo no imaginário cristão. São Paulo: Ática, 1986. 
OLIVEIRA, Estela Ramos de Souza. O diabo violeiro: uma análise a partir da obra Dona do capeta. In FERRAZ, Salma (org.). Pólen do divino: textos de teologia e literatura. Blumenau: Edifurb; Florianópolis: FAPESC, 20011, p.171-179.

PAGELS, Elaine. As origens de satanás. Tradução Ruy Jungmann. 2. ed. São Paulo: Ediouro, 1996.

SARTN, Philippe Delfino. O diabo e o barroco na obra de Manuel Bernardes (1644-1710). In FERRAZ, Salma (org.). Pólen do divino: textos de teologia e literatura. Blumenau: Edifurb; Florianópolis: FAPESC, 20011, p.71 -85 .

SEGOLIN, Fernando. Personagem e anti-personagem. São Paulo: Editora Olho d'Água, 2006.

TAVARES, Hênio. Teoria da literatura. Belo Horizonte, MG: Itatiaia, 2002.

TAUSIER, Maria; AMELANG, James. El diabo em La Edade Moderna. Madrid, Marcial Pons Historia, 2004.

VAUCHEZ, André. Sermões. A espiritualidade na Idade Média Ocidental (século VIII a XIII). Rio Grande do Sul: Edelbra, 1998, 12 volumes.

WILKINSON, Tracy. Os exorcistas do Vaticano. Rio de Janeiro: Ediouro, 2008.

GABEL, John B; WHEELER, Charles B. A Bíblia como literatura. São Paulo: Edições Loyola, 1993.

ZUCK, Roy B. A interpretação bíblica. São Paulo: Vida Nova, 1994.

\section{Imagem}

1. Disponível em http://4.bp.blogspot.com/-URauJEnJJJU/ T-h8QZM2vcI/AAAAAAAADM0/j2EoYlekJYU/s1600/ xfig+Franz+Von+Stuck+Scherzo.jpg, consultado em 07/10/2012

2. Disponível em http://www.warriorsoul.com.br/images/Lucifer_ anime.jpg?692. Consultado em 07/10/2012 



\section{Sadismo ou Demonismo na poética de Machado de Assis}

Fabiana Gonçalves (UNESP) ${ }^{1}$

"O gosto pela crueldade apresenta traços humanos."

Umberto Eco (História da feiúra)

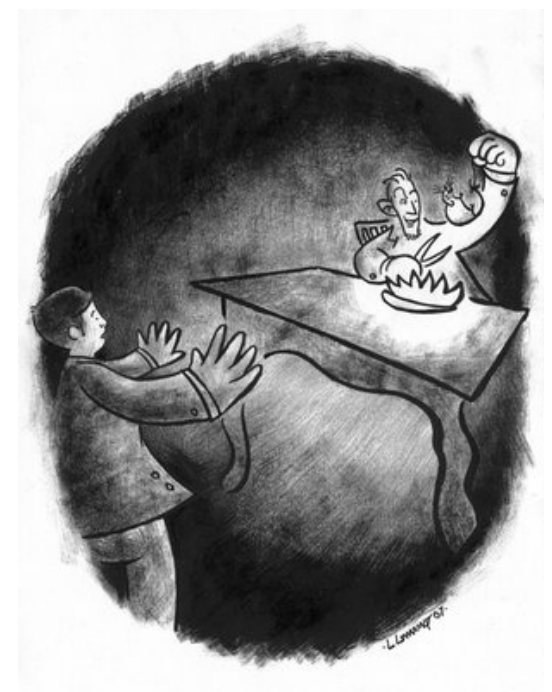

O soneto "À Ilma. Sra. D. P. J. A.”, dedicado a uma certa D. Petronilha, marca "até melhor aviso", para usar uma expressão de José Galante de Sousa, o início da carreira literária de Machado de Assis.

1 Doutoranda em Letras na UNESP/Assis. Recentemente publicou artigos sobre a poesia de Machado de Assis em revistas eletrônicas especializadas e atuou como membro do corpo editorial da Miscelânea: Revista de Pós Graduação em Letras. E-mail: fabivotu@ yahoo.com.br. 
Desde a publicação desse poema no Periódico dos Pobres em 3 de outubro de 1854 até 1908, Machado escreveu cerca de duzentos poemas, dedicou-se à tradução de poetas clássicos, contemporâneos, desconhecidos ou canônicos, e ainda produziu 48 crônicas versificadas. Desse conjunto, resultou em 1901 a antologia Poesias completas. Nesse volume, o poeta reeditou alguns dos poemas recolhidos em seus três primeiros livros de poesia - Crisálidas (1865), Falenas (1870) e Americanas (1875) - e apresentou ao público sua derradeira coletânea: Ocidentais.

Com relação ao exercício poético observado nessa última compilação, Cláudio Murilo Leal ressalta: "Em Ocidentais Machado de Assis domina inteiramente os segredos do artesanato poético, a par de ter adquirido uma cosmovisão que o permite superar o episódico e construir uma poesia em que são questionados os metafísicos problemas do Ser e do Mundo" (LEAL, 2008, p. 144). De fato, a maioria das composições responsáveis pelo reconhecimento de Machado de Assis poeta está nesse volume. Dentre as mais cultuadas, estão "Circulo vicioso"; "A mosca azul", "Uma criatura", "Mundo interior", e as recriações de "The raven", de Edgar Allan Poe, e do solilóquio shakespeariano "To be or not to be". Embora pouco lembrado, também podemos incluir nesta lista o poema "Suave mari magno".

Lançado pela primeira vez na Revista Brasileira em 15/01/1880 e posteriormente coletado nas Ocidentais, "Suave mari magno" apresenta um tema pouco comum na obra machadiana: o prazer diante do sórdido. Validando a presença do sadismo na poética de Machado de Assis, a narrativa de "A causa secreta", conto originalmente publicado na Gazeta de Notícias em 01/08/1885 e compilado dez anos depois em Várias histórias, também se dedica ao temário sádico.

\section{Khatarsis e sadismo}

Reconhecido também por purificação, o vocábulo catarse, pouco explicado inclusive pelo próprio Aristóteles, tem rendido muitas e variadas discussões nas mais diversas áreas do conhecimento. Um dos pontos-chave da poética aristotélica, o prazer catártico refere-se grosso modo às emoções suscitadas pela tragédia. Dito de outra maneira e igualmente em poucas palavras, na arte a catarse associa-se às reações 
apresentadas por indivíduos quando vivenciam uma experiência estética. Após a contemplação artística, “... estas almas se sentem aliviadas agradavelmente. O mesmo acontece com as almas presas de compaixão ou de terror ou de outra... paixão". ${ }^{2}$. Sob esse prisma, a teoria de Aristóteles nos induz a refletir sobre uma possível nuance desse mesmo fenômeno: o sadismo.

Modernamente difundida por Marques de Sade, cujo nome deu origem ao termo, a arte sádica, entre outros aspectos, busca demonstrar como o gosto pela crueldade está incrustado à natureza humana. Contemporâneo de Sade, Friedrich Schiller ao discorrer sobre a "disposição natural" do homem ao trágico observa: "É um fenômeno geral na nossa natureza, que aquilo que é triste, terrível e mesmo horrendo nos atraia com um fascínio irresistível; que certas cenas de dor e terror nos afastem, mas com a mesma força nos atraiam de volta [...]" (SCHILLER, apud ECO, 2007, p. 220).

De fato, conforme realça Umberto Eco (2010, p 222), desde os tempos dos anfiteatros romanos onde os rituais de suplício e execuções ganhavam contornos de espetáculos, a história registra atos de violência servidos em verdadeiros banquetes a fim de satisfazer o anseio popular. Ficcionalmente, o sadismo apresenta-se, sobretudo, de modo metafórico e quase sempre subscreve uma intenção subliminar de condenação ou denúncia às práticas violentas e/ou opressivas. Inúmeros autores retrataram artisticamente a violência enquanto estímulo do prazer e com isso relegaram aos pósteros inequívocos testemunhos verbais/pictóricos de diversas vertentes do comportamento sádico. Sade, escritor responsável pela popularização da atividade literária em torno do sadismo, além de celebrar o desprezo pelo corpo alheio, tacitamente também utilizou as diversas faces de sua obra como forma de desmascaramento dos poderes exploratórios da França do século XVIII.

Ampliando os horizontes sádicos, um dos escritores preferidos de Machado de Assis, Edgar Allan Poe, evidenciou no conto "O gato preto" que a violência não atinge apenas os humanos. A tortura infligida

2 O trecho transcrito consta do texto introdutório da Arte poética. A autoria, embora os comentários nesta edição nos levem a crer que o tradutor seja também o introdutor, não é identificada. Para mais detalhes ver: ARISTÓTELES. Arte poética. [Tradução de Pietro Nassetti] São Paulo: Martin Claret, 2003. 
a um gato na narrativa de Poe assemelha-se muito com o martírio aplicado por Fortunato ao rato em "A causa secreta". Convém ressaltar a proximidade de Machado de Assis com os textos do escritor, lidos diretamente do original. A predileção e familiaridade à literatura de Poe foram registradas por diversas vezes pelo próprio poeta e enfatizadas através de recriações, citações e alusões a obras do autor norte-americano. Longe de fermentar ainda mais os imbróglios envolvendo o paradigma de originalidade na obra machadiana, importa notar as ressonâncias entre a personalidade do causador de tanta aflição em "A causa secreta" e a do protagonista impiedoso de "O barril de Amontillado", publicado em 1846. Ambas as personagens poderiam ser classificadas de amantes do sofrimento. Além disso, talvez tenha saído dessa narrativa o nome da personagem machadiana ${ }^{3}$.

Duplamente vítima, o cão aparece em "Suave mari magno" padecendo de uma crise convulsiva e ao mesmo tempo protagonizando um espetáculo a céu aberto. Aos curiosos, deleite garantido pela dor alheia. Apenas coincidência ou propositadamente uma tentativa de atenuar os efeitos da violência, fato é que tanto no conto quanto no poema as vítimas das ações sádicas são animais, um rato e um cão respectivamente. No poema, a curiosidade dos transeuntes os detém perante a tragicidade da morte, e no conto, a fascinação de Fortunato pela tortura evita uma execução fatal instantânea. Assim, sob pretextos duvidosos, a personagem aprecia lentamente a destruição gradual do rato. Contudo, quando o objeto de prazer de Fortunato materializa-se na figura do amigo Garcia aos prantos diante do cadáver de Maria Luísa, a "justificativa" utilizada anteriormente (a personagem sádica atribui ao rato a destruição de um documento, por isso a tortura) dilui-se por completo.

Produzidas na mesma década, as duas composições retratam a privação de liberdade, o desfiguramento e o sofrimento alheio como fontes prazerosas. Passemos então aos pormenores sádicos promulgados por "Suave mari magno" e "A causa secreta".

3 No início do conto de Poe, o narrador apresenta Fortunato ao leitor: 'The thousand injuries of Fortunato I had borne as I best could ; but when he ventured upon insult, I vowed revenge.' "Eu aguentara as incontáveis injúrias de Fortunato da melhor forma possível, mas quando ele se atreveu a me insultar jurei vingança”" (Tradução de Guilherme da Silva Braga). 


\section{A curiosidade sádica em verso e prosa}

Recuperando as palavras iniciais do segundo volume da obra De rerum natura (Sobre a natureza das coisas), de Titus Lucretius Carus que viveu durante o século I a.C, Machado de Assis intitula o poema e ao fazê-lo ilumina um dos maiores poetas e filósofos de língua latina. Lucrécio, conforme ficou conhecido no idioma português, poeticamente afirma: "Suave, mari magno turbantibus aequora ventis e terra magnum alterius spectare laborem; non quia vexari quemquamst iucunda voluptas, sed quibus ipse malis careas quia cernere suavest". ${ }^{4}$ Embora relacionado ao epicurismo, cuja doutrina prega o prazer através da libertação dos temores e das culpas, Lucrécio lança com essa passagem as bases para "Suave mari magno".

A alusão ao fragmento latino imediatamente no pórtico do poema introduz o leitor em um universo polarizado pela dor e pelo alívio. Por um lado, o trecho de Lucrécio, assim como os versos machadianos, expõe as intempéries sofridas por determinados seres, e por outro o bem-estar experimentado por aqueles que se julgam salvos dos mesmos infortúnios. Afora a similitude inicial evidenciada pelo título, a composição machadiana afasta-se do pensamento latino, na medida em que descarta a ideia genuína e desinteressada do alívio para potencializar o prazer diante do sofrimento. Estruturado sob a forma do soneto, estrutura poética designada tradicionalmente para expressão do belo, "Suave mari magno" recorre a vocábulos ligados à doença, à metamorfose, à morte enfim, para simbolizar o gosto humano pela crueldade.

Lançado no mesmo ano de Memórias póstumas de Brás Cubas, cujo capítulo reservado para o delírio do defunto-autor apresenta a figura da natureza alegorizada como "mãe e inimiga" divertindo-se com a agonia alheia, "Suave mari magno" recebeu diversas interpretações. Para Lúcia Miguel Pereira (1988, p. 236), os versos traduzem um drama autobiográfico. Em decorrência das crises epilépticas, Machado de Assis teria

4 “É bom, quando os ventos revolvem a superficie do grande mar, ver da terra os rudes trabalhos por que estão passando os outros; não porque haja qualquer prazer na desgraça de alguém, mas porque é bom presenciar os males que não se sofrem. É bom também contemplar os grandes combates de guerra travados pelos campos sem que haja da nossa parte qualquer perigo." (Tradução de Agostinho da Silva) 
transposto para os versos a humilhação e indiferença sentidas durante as convulsões sofridas em público. Abaixo, os quartetos dedicados à descrição das deformidades causadas pelo ataque:

Lembra-me que, em certo dia,

$\mathrm{Na}$ rua, ao sol de verão,

Envenenado morria

Um pobre cão.

Arfava, espumava e ria,

De um riso espúrio e bufão,

Ventre e pernas sacudia

Na convulsão. ${ }^{5}$

Com efeito, Machado pode ter retratado um episódio particular em "Suave mari magno", no entanto, o meio empregado para desenvolver a tópica desvincula as ações versejadas de uma experiência unicamente pessoal e as conecta ao universal humano. A construção de uma personagem antropomorfizada - "De um riso espúrio e bufão" -, atrelada à ironia machadiana, responsável pela caracterização de um sorriso fake e jocoso ao cão, expande o horizonte de leitura, sugerindo assim outros caminhos interpretativos. Dessa forma, o poema revela-se, para compartilhar uma expressão difundida por Eco, "opera aperta".

Portanto, a ambuiguidade presente em "Suave mari magno" institui frestas para o leitor atento incursionar por suas camadas mais profundas e desse modo desvendar os recônditos dos versos. Seguindo esse raciocínio, o poema machadiano apresenta num primeiro nível um percurso superficial, cuja compreensão abarca o significado literal dos vocábulos, isto é, a convulsão de um cão envenenado e a permanência das pessoas diante da cena, e subliminarmente permite o aparecimento de outras possibilidades interpretativas. Ancorando-se no viés biográfico, Leal, um dos

5 As transcrições dos versos de "Suave mari magno" seguem o volume ASSIS, Joaquim Maria Machado de. Obra completa em quatro volumes: edição anotada. [Organização Aloizio Leite Neto, Ana Lima Cecílio, Heloisa Jahn]. 2. ed. Rio de Janeiro: Nova Aguilar, 2008. 3. v, p. 577. 
poucos especialistas a dedicar-se ao poeta, limita-se a observar: "'Suave mari magno" reflete o pessimismo do autor, o seu ceticismo em relação à concepção da bondade natural do homem.” (LEAL, 2008, p. 146).

Quanto à estrutura de "Suave mari magno", podemos caracterizá-la como um estandarte da linguagem cultivada pela poesia machadiana. Oscilando entre as orientações livres do romantismo e as regras do parnaso brasileiro, o poeta encapsulou os versos assimétricos de "Suave mari magno" em uma forma poética padronizada. Os dois tercetos, constituídos em ritmo ascensional tonalizado por uma voz reprovadora que reprime o comportamento do passante curioso, marcado, sobretudo, pela sequência de encerramento "Como se lhe desse gozo/ Ver padecer", seguem o mesmo modelo:

\author{
Nenhum, nenhum curioso \\ Passava, sem se deter, \\ Silencioso. \\ Junto ao cão que ia morrer, \\ Como se lhe desse gozo \\ Ver padecer.
}

Enquanto as duas estrofes iniciais descrevem a metamorfose canina, os tercetos retratam primeiramente a indiferença dos pedestres perante a tragédia encenada em plena rua e, em seguida, exprimem uma versão mais apurada desse comportamento, ou seja, demonstram a provocação do eu-poemático a respeito de um suposto deleite dos espectadores diante do sofrimento alheio. Simbolicamente, o poema evidencia a condição humana atrelada ainda aos instintos mais primitivos de crueldade e desamor. A razão para nenhum curioso, mas nenhum mesmo - como o verso enfatiza por meio da repetição do vocábulo - deixar de assistir a um show de horror e/ou evitar uma brutalidade qualquer se resume no fascínio natural do homem pelo horrendo, isso porque "O filho bruto da natureza, sem as rédeas de nenhum sentimento de humanidade, abandona-se sem pudor a esse poderoso impulso.” (SCHILLER, apud ECO, 2007, p. 220).

Fortunado, personagem de "A causa secreta", bem o sabe, pois não resiste às enfermidades físicas ou morais dos indivíduos a sua volta e no ápice de sua obsessão sádica chega a provocá-las. Além de Fortunato, o 
conto apresenta a esposa dele, Maria Luísa, e Garcia, estudante de medicina e amigo do casal. No início da história, o narrador relata como fora o encontro dos futuros amigos num teatro: "A peça era um dramalhão, cosido a facadas, ouriçado de imprecações e remorsos $[\ldots]^{6}$. Nos lances dolorosos, a atenção dele (de Fortunato) redobrava, os olhos iam avidamente de um personagem a outro, a tal ponto que o estudante suspeitou haver na peça reminiscências pessoais do vizinho."

O tempo e as oportunidades os aproximaram. Aproveitando-se da profissão do amigo, Fortunato propôs-lhe uma sociedade: a abertura de uma casa de saúde. Apesar da relutância de Garcia, o projeto concretizou-se. A dedicação de Fortunato aos doentes surpreendia o médico: "Não recuava diante de nada, não conhecia moléstia aflitiva ou repelente, e estava sempre pronto para tudo, a qualquer hora do dia ou da noite.". A amizade com o sujeito de alma misteriosa também estreitou os laços entre Garcia e Maria Luísa, e "Manso e manso, entrou-lhe o amor no coração.". À pretexto do novo trabalho, "Fortunato metera-se a estudar anatomia e fisiologia, e ocupava-se nas horas vagas em rasgar e envenenar cães e gatos.". No clímax da narrativa, a esposa, adoentada, flagrou ao lado do amigo a cena reveladora da causa secreta responsável pela personalidade estranha do marido. Ambos assistiram a tortura infligida por Fortunato a um rato. Ao executá-la, sentia: “[...] tão somente um vasto prazer, quieto e profundo, como daria a outro a audição de uma bela sonata ou a vista de uma estátua divina, alguma coisa parecida com a pura sensação estética".

Desvendada a identidade sádica de Fortunato, o quadro de Maria Luísa agravou-se. Desde então, o marido "Não a deixou mais; fitou o olho baço e frio naquela decomposição lenta e dolorosa da vida, bebeu uma a uma as aflições da bela criatura, agora magra e transparente, devorada de febre e minada de morte.". No final do conto, Garcia desesperado beija o cadáver de Maria Luísa. Fortunato não teve ciúmes, apenas embebido de prazer "saboreou tranquilo essa explosão de dor moral que foi longa, muito longa, deliciosamente longa.”.

6 As passagens de "A causa secreta" seguem o volume ASSIS, Joaquim Maria Machado de. Obra completa em quatro volumes: edição anotada. [Organização Aloizio Leite Neto, Ana Lima Cecílio, Heloisa Jahn]. 2. ed. Rio de Janeiro: Nova Aguilar, 2008. 2. v, pp. 476-483. 
Após essa síntese, necessária para seguirmos com as aproximações entre a narrativa e o poema, convém ressaltar alguns aspectos circundantes à literatura machadiana. Considerada a fortuna crítica do autor, a prosa, em contraposição à atenção dispensada a sua produção em verso, recebeu inúmeros enfoques. Em Machado de Assis: um escritor nos trópicos (1998), Patrícia Lessa Flores da Cunha discute as confluências entre a atividade contística do autor brasileiro e a de Poe. De acordo com a ensaísta, o poeta norte-americano concebeu a unidade de efeito para levar seus leitores, ainda que dispersos em lugares diferentes, a sentir com a mesma intensidade o conteúdo de sua prosa. Segundo Cunha, a relação de Machado de Assis com o leitor era igualmente forte, porém, a teoria do contista fluminense constitui-se de modo bastante diverso, isso porque a presença de um narrador pretensamente indiferente, como acontece na maioria das narrativas machadianas, instabiliza o texto e, consequentemente, amplia as possibilidades de leitura.

Nesse caso, o efeito do conto machadiano "não é apenas fruto da técnica ou da habilidade do escritor em lidar com elementos expressivos da linguagem que utiliza e cria, mas decorre principalmente do 'susto' que dá no leitor” (CUNHA, 1998, p. 107). Logo, compete ao leitor a opção de escolha de como ler a narrativa, levar ou não o susto. Entretanto, para desnudar uma história de amor infeliz ou então uma série de acontecimentos corriqueiros e dessa forma desvendar o "outro" texto, a ação do intérprete é fundamental. Nessa linha, os contos machadianos apresentam dois níveis narrativos: o primeiro, mais acessível, estabelece a história narrada, e o segundo, institui o texto subliminar sugestionado e aberto a múltiplas interpretações.

\section{Últimas intersecções}

O eixo temático do conto "A causa secreta" e o mote poético desenvolvido em "Suave mari magno" assemelham-se. Ambos retratam o gosto perverso pela degeneração como característica inerente ao ser humano. Com efeito, os atos sádicos expostos na narrativa e no poema são atribuídos a indivíduos pertencentes a núcleos sociais comuns, até mesmo os curiosos desconhecidos retratados no poema indicam uma vida regular, na medida em que caminham livremente pela rua. Não se trata, portanto, de painéis ocupados por personagens assumidamente acometidas 
por síndromes psiquiátricas; pelo contrário, os agentes ou observadores do sofrimento alheio nessas composições representam tipos "normais".

Formalmente, a narrativa segue o esquema tradicional de formulação contística: anúncio de um conflito - desenvolvimento - desfecho. Assim como acontece em "A causa secreta", o poema também apresenta um enredo com início, meio e fim. Nesse sentido, poderíamos identificá -lo como um mini-poema narrativo. Assim sendo, o primeiro quarteto lança o conflito, facilmente adaptável para o texto em prosa (Lembro-me que em certo dia de verão um cão envenenado morria), em seguida, ocorre o desenvolvimento e ápice desse conflito (nesse momento as reações convulsivas do animal são narradas) e por último, nos dois tercetos, há o desenlace da história: nenhum curioso passava sem se deter diante da cena demonstrando prazer.

A possibilidade de compreender os poemas machadianos pelo viés da prosa levou Cláudio Murilo Leal (2008) a creditar à poesia de Machado de Assis certa "vocação narrativa". No ensaio "Um poeta todo prosa" (1998), o pesquisador investiga a presença de procedimentos narrativos descrição de personagens, cenários, narrador, enredo - na produção em verso do autor e examina até que ponto o aproveitamento dessa linguagem foi benéfica à poesia machadiana. De acordo com o Leal:

É possível afirmar que a influência da prosa atuou de duas maneiras na poesia de Machado. Uma, negativamente, enfraquecendo a voz do poeta lírico, devido ao uso abusivo de lugares comuns e clichês, que reduzem a tensão da linguagem. Outra, de maneira positiva, trazendo para a poesia uma consciência humanística, ainda válida nos dias de hoje, inclusive ao exercer uma função ética, para que a literatura não se perca nos jogos fúteis das formas poéticas, autárquicas e vazias (LEAL, 1998, p. 214).

Nesse sentido, convém ressaltar a censura do eu-poemático em "Suave mari magno" ao comportamento do passante curioso que se mostra extasiado com o sofrimento alheio; conduta esta também verificada na narrativa de "A causa secreta", onde a personagem responsável pelas atrocidades contra o rato é desqualificada física e moralmente pelo narrador. Assim como sugestionado nessas produções, muitas vezes buscamos repelir e até mesmo desumanizar as ações sádicas relacionando-as a impulsos demoníacos, porém não sabemos "[...] se é o demônio quem 
empurra os seres humanos em direção à crueldade ou se não é uma tendência natural à crueldade que os leva a imaginar, como justificativa e motivo de excitação, uma relação com o diabo.” (ECO, 2007, p. 220). A decisão pertence ao leitor.

\section{Bibliografia}

ARISTÓTELES. Arte poética. [Tradução de Pietro Nassetti] São Paulo: Martin Claret, 2003.

ASSIS, Joaquim Maria Machado de. Obra completa em quatro volumes: edição anotada. [Organização Aloizio Leite Neto, Ana Lima Cecílio, Heloisa Jahn]. 2. ed. Rio de Janeiro: Nova Aguilar, 2008. v. 4.

CARO, Tito Lucrécio. De rerum natura. Tradução Agostinho da Silva. Introdução de E. Joyau e G. Rebbech. Rio de Janeiro: Globo, 1962.

CUNHA, Patrícia Lessa Flores da. Machado de Assis: um escritor na capital dos trópicos. Porto Alegre: IEL: Editora Unisinos, 1998.

. História da feiúra. [Tradução de Eliana Aguiar]. Rio de Janeiro: Record, 2007.

LEAL, Cláudio Murilo. O circulo virtuoso: a poesia de Machado de Assis. Brasília, DF: Ludens, 2008.

. Um poeta todo prosa. In: SECCHIN, Antonio Carlos. et al (Org.). Machado de Assis: uma revisão. Rio de Janeiro: In-Fólio, 1998. pp.

PEREIRA, Lúcia Miguel. Machado de Assis: estudo crítico e biográfico. 6. ed. rev. Belo Horizonte: Itatiaia; São Paulo: Edusp, 1988.

POE, Edgar Allan. O gato preto e outros contos. [Organização e Tradução de Guilherme da Silva Braga]. São Paulo: Hedra, 2008.

\section{Imagem}

Disponível em http://2.bp.blogspot.com/-NwezqnU1TEs/TrrjVi6a9II/ AAAAAAAAAac/Lfe4dOoPOuk/s1600/causa_secreta1.jpg. Consultado em 07/10/2012 



\section{A representação do demoníaco na cultura africana em Do Amor e Outros Demônios, de Gabriel García Márquez}

Fernanda Medeiros de Figueirêdo ${ }^{1}$ (PPGLI-UEPB)

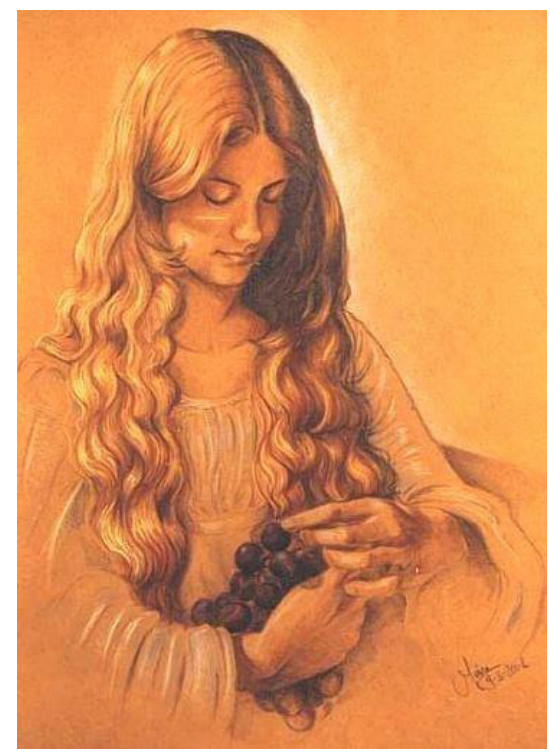

Do amor e outros demônios, obra do escritor colombiano Gabriel García Márquez, é marcada pelo contexto colombiano-caribenho do final do século dezoito, durante o vice-reinado da Colômbia, esta sendo ainda colônia da Espanha.

1 Mestranda em Literatura e Interculturalidade pela UEPB. Graduada em Comunicação Social pela mesma universidade. Email: nandavarzea@gmail.com 
A narrativa conta a história da adolescente Sierva Maria de Todos los Ángeles, que foi fruto de um plano da mãe Bernarda Cabrera (uma plebeia pobre) para casar com Ygnacio (marquês rico) por causa dos seus bens materiais. A menina nasceu de sete meses, enlaçada pelo cordão umbilical e, além disso, rejeitada pelos pais e prometida aos santos e orixás africanos pela escrava Dominga de Adviento, que prometeu que se a criança sobrevivesse não cortaria os cabelos até o dia do seu casamento. Esta foi criada junto aos escravos, onde aprendeu a cultura africana, suas línguas e danças. Sendo neste sentido que Magalhães (2008, p.3) afirma que "após seu nascimento [Sierva] foi batizada em Cristo e consagrada a Olokum", o que já representa a primeira contradição dentro de um contexto onde a religião e os costumes africanos não eram bem aceitos pelo cristianismo e pela própria sociedade.

Mais tarde, sendo mordida por um cachorro na ocasião em que foi ao bairro dos escravos em companhia de uma escrava comprar guizos para celebrar a festa de seus doze anos, a criança apresenta sintomas a princípio considerados pelos médicos como raiva, mas vistos pela igreja católica como possessão demoníaca.

O fato ocorreu no auge da Inquisição Moderna, levada a cabo pela Espanha e Portugal desde o século XV, nas sedes de seus reinos e em seus domínios coloniais, a qual, segundo Anita Novinsky "ultrapassou de longe a crueldade e intensidade da Inquisição papal na Idade Média”. (ARAÚJO, p.6)

Por este viés, abordamos neste artigo até que ponto os mitos a respeito do "mal" são apresentados nas diferentes culturas, priorizando o impacto causado pelos ritos e pela cultura africana na América Latina, uma vez que a "cultura dos negros" é vista pelo clérigo e pela sociedade como predisposição a atrair demônios diversos, embora o termo demônio possa ser interpretado ao longo da obra de maneiras diversas. $\mathrm{O}$ demônio é explicado pela igreja e seus adeptos como possessão maligna - o mal corporificado - o que culminou com os exorcismos (do grego exorkismós, "ato de fazer jurar", pelo latim exorcismu), designando o ritual executado por uma pessoa devidamente autorizada para expulsar espíritos malignos (ou demônios) de outra pessoa, prática bastante utilizada na Inquisição, quando se julgava que havia crimes de duas naturezas: 
De um lado estavam aqueles contra a fé, que eram considerados os mais graves e tinham as penas mais severas; de outro, os contra a moral e os costumes, que comportavam toda uma gama de modalidades, tais como bigamia, sodomia, feitiçaria etc., e que, inclusive, se misturavam com o campo religioso. (ARAÚJO, p. 11-12).

Considerando o imaginário e as identidades que permeiam a trama, esperamos abordar as representações do demoníaco nos costumes e santos de um povo subjugado durante o sistema colonial. Além da opressão imposta ao povo africano, o cristianismo teme e pune a liberdade de pensamento em relação às questões espirituais e identitárias.

Também é importante ressaltarmos que estamos analisando o demônio enquanto força maligna, termo recorrente do catolicismo, e também como o mal dentro das pessoas, não por motivos espirituais, e sim através da imagem que as pessoas atribuem ao desconhecido, neste caso, ao povo africano em terra estrangeira. Para adentrarmos esse estudo e relacionarmos a intolerância religiosa e cultural com conceitos já estabelecidos, utilizamos como pressupostos teóricos as colocações de DURAND (2004), MAGALHÃES (2008), LANDOWSKI (2002), FANON (2008), entre outros autores.

\section{Crises identitárias no colonialismo}

Longe de mostrar um contexto de tolerância cultural, Do Amor e Outros Demônios é a representação de um povo colonizado e subjugado aos "conhecimentos" de outrem, que aponta como "errada ou pecadora" toda e qualquer manifestação que não seja comum ao país e a seus nativos.

Entre alguns estudos focados na obra do escritor colombiano Gabriel García Márquez, alguns colocam como foco norteador a teoria psicanalítica para explicar a possessão demoníaca defendida pelos Tribunais Eclesiásticos da Igreja Católica, outros a colonização, ou ainda o fator religioso e norteador das vidas e destinos dos personagens principais. O que pretendo destacar ao longo da trama é a não aceitação de ritos e cultos africanos; o mal sempre provindo da cultura negra presente na 
localidade onde se passa toda a narrativa, ou seja, o estranhamento e a rejeição ao estrangeiro, a tudo que não pertence à "sociedade oficial" e, sobretudo, a valorização dos mitos e a importância do imaginário no desenrolar das ações narradas.

É importante frisar, como lembra Magalhães (2008), a resistência que culturas e religiosidades possuem na defesa de seus conteúdos e práticas. Dessa forma, na obra fica evidente que o clérigo, através do retiro de Sierva em um convento e do exorcismo imposto à criança, não pretende ajudá-la, mas tão somente tratá-la de um "mal” e infligir os cânones e crenças cristãs, inferiorizando e ridicularizando os cultos, costumes e a religião afro-colombiana. Exemplo disso é que os três idiomas africanos falados por Sierva foram observados pelas clarissas do convento como atributos satânicos, uma vez que a menina sentiu-se em seu mundo, pois ali era o lugar onde os escravos negros do Convento Santa Clara reconheciam seus colares de macumba e falavam a linguagem ioruba.

Além do mundo colonial tão bem retratado em Do Amor e Outros Demônios, Márquez revela o mundo do outro em um contexto de estranhamento. $\mathrm{O}$ estrangeiro, neste caso o africano, já chega com rótulo de dominado, classe inferior; escravo que é obrigado a submeter-se aos costumes da sociedade dominante, que ironicamente, também é reprimida pelas regras e tradições, muitas vezes cruéis, do cristianismo. Fato que corrobora a afirmação do teórico Eric Landowski de que "[...] toda diferença de comportamento um pouco marcada, pela qual o estrangeiro trai sua proveniência, parece para ele (assimilador do grupo dominante), extravagância despida de razão." (LANDOWSKI, 2002, p. 6)

Neste sentido, a representação do mal na obra de Márquez está sempre condicionada à imagem do africano ou do diferente, alheio às regras, seja em seu aspecto social ou cultural, e principalmente religioso. É tanto que o princípio que levou todos a crerem que a menina estava possuída por um demônio foi o fato de ela ser uma marquesa de pele branca, mas de "alma" negra. A jovem foi criada em um alojamento de escravos, com costumes e tradições africanas vividas no anonimato, silenciadas para não agredir a cultura branca e cristã, inclusive revelada pelo autor com toda a sua carga de incertezas, resistências, falhas e medo. 
Mesclam-se diversas culturas em busca de identidade, uma vez que muitos personagens possuem cidadanias construídas e decadentes, como, por exemplo a esposa sem títulos do marquês - Bernarda Cabrera - filha de índio ladino com branca de Castella, e que se auto afirmava 'não negra'. Também o próprio padre Cayetano Delaura, criado no Novo Reino de Granada, era filho de uma nativa de San Martín de Loba, na província de Mompox, que emigrara com os pais para a Espanha, mas sempre convencido de que seu pai era descendente direto de Gargilaso de la Vega. Ou seja, a trama sempre apresenta personagens que não reconhecem o outro, ou mesmo o outro dentro de si. Todos vivem perturbados com seus próprios demônios, o mal provindo de características, raças e situações consideradas inferiores pela sociedade nativa e sua cultura. E todos estes preferem apontar, por orientação da igreja Católica, os demônios africanos presentes na menina branca com costumes negros.

Percebe-se então que nos processos relativos à diferença e à identidade sobrepõe-se uma relação de poder do mais forte, uma luta pela hegemonia que tem início em uma espécie de demarcação de território através da cultura que "vale mais". Os negros fazem seus rituais e práticas escondidos, uma vez que os brancos, comandados sempre pelo poder do clérigo (que reina exatamente por meio do domínio que emana da fé e do medo) se colocam em posição de destaque em um embate de posicionamentos ideológicos. Sobre isto, entende-se que:

A identidade e a diferença estão, pois, em estreita conexão com as relações de poder. O poder de definir a identidade e de marcar presença não pode ser separado das relações mais amplas de poder. A identidade e a diferença não são, nunca, inocentes. (SILVA, 2000, p.81)

Uma vez que a própria diferença é utilizada como recurso do poder da igreja para apontar os demônios presentes na cultura africana e assim fazer a sociedade esquecer-se dos próprios enganos e deficiências que os cercam, essa conexão apontada pelo autor citado demonstra a relação de poder entre crenças e culturas distintas. Uma que tende a impor seu poder com violência e outra que pratica seus rituais de forma mais oculta possível, protegendo e assumindo sua identidade de maneira camuflada. 


\section{Cultura mitificada - estrangeiro ou demônio?}

A obra apresenta não só o estrangeiro africano, mas também as identidades escondidas no interior de pessoas que assumem máscaras para serem aceitas pela sociedade e pelo domínio cristão. Sierva María era na verdade Maria Mandinga, a negra devota e praticante de cultos e costumes africanos, que viu sua vida mudar drasticamente após uma mordida, causadora de doença ou possessão demoníaca, algo que aparentemente só existiu para os outros.

Além disso, Magalhães em debate informal, afirmou ainda que essa mordida pode ser metaforicamente interpretada: $O$ demoníaco, neste caso, está presente em diferentes relações, nas variadas tramas. E a mordida do cão é uma alegoria que elucida todo o restante da trama, uma vez que há elementos determinantes em torno deste cão: 1) O próprio nome “cão" pode ser associado ao diabo; 2) Ele estaria com raiva, então aponta para uma influência violenta, feroz sobre a vida; 3) Vem do mundo animal, o que configura que forças para além da cultura entram na cultura, invadem o cotidiano, alteram práticas e possuem corpos.

Esse foi então o primeiro passo para a morte tão precoce de Sierva, consequência da mitificação de uma cultura e da intolerância de outra. E tratando-se de imaginário, cabe então recorrer às colocações de Durand (2004, p.7) no que diz respeito ao costume do Ocidente em considerar-se "o único herdeiro de uma única verdade", na maioria das vezes opondo-se e desafiando as imagens, em uma constante atitude de desconfiança iconoclasta, na qual essas imagens são, no mínimo, suspeitas.

A partir disso podemos lembrar a figura de Sierva com suas longas madeixas ruivas e pele muito branca, com um aspecto de menina astuta (considerada uma espécie de feiticeira por muitos) - presente na narrativa onde a imaginação corrobora a suspeita de ser "amante do erro e da falsidade", afirmação feita pelo filósofo francês Nicolas Balebranche.

Ainda de acordo com Gilbert Durand, agora em seu livro A Imaginação Simbólica, ele afirma que a consciência tem duas formas de apresentar o mundo. E em uma dessas formas situamos a representação imagética de um poder que supera os limites humanos (da morte, por exemplo), 
esse poder que tanto pode ser divino como demoníaco. O importante é a forma e as características que a consciência atribui àquela imagem desconhecida.

Um directa, na qual a própria coisa parece estar presente no espírito, como na percepção ou na simples sensação. A outra indirecta quando, por esta ou por aquela razão, a coisa não pode apresentar-se em $<<$ carne e osso $>>$ à sensibilidade, como por exemplo na recordação da nossa infầncia $[\ldots]$ ou na representação de um além morte. (DURAND, 1964, p.7)

O mito, intuição visionária da alma já conhecida desde os gregos, admite verdades indemonstráveis, dentre as quais a imagem mítica muitas vezes se sobrepõe à razão e causa resistências e até severas rejeições, como aconteceu à menina com todos os seus dezesseis colares e trejeitos africanos, embora brancura marcante, sugestionando inclusive um atributo a mais para reafirmar uma presença demoníaca através da imagem: a brancura extrema em meio à negritude africana.

Da mesma forma que em outros tempos as imagens de santos nas igrejas cristãs foram vistas pelos imperadores de Bizâncio como ameaça à pureza iconoclasta, no tempo em que se passa a narrativa, foi a imagem da religião africana em território caribenho dominado pelo poder sacro que foi vista como ameaça ao bem comum, à paz que emana do único Deus aceito pelo cristianismo. E como ocidente marcado por uma única verdade, esta pode ser considerada apenas uma das batalhas em uma guerra contínua pelo domínio do que é certo ou errado.

Como bem colocou Durand (Ibidem, p. 83) Freud já observara anteriormente que o herói depende do monstro ou do dragão para transformar-se em herói, sendo assim era necessário para a igreja cristã daquela época, marcada pelo que Magalhães (2008, p.2) conceituou de decadência e esgotamento espiritual da cristandande colonial, maximizar os monstros presentes na religião do outro (afro-colombiana) e distorcer uma rede de imagens simbólicas coligidas em mitos e ritos para assim ser talvez considerada a religião mais lógica dentro de um contexto marcado pelo caos, pela desordem e pela confusão mental. 
O autor Frantz Fanon argumenta que a colonização requer mais do que a subordinação material de um povo. Ela também fornece os meios pelos quais as pessoas são capazes de se expressarem e se entenderem, o que também os colocaria na relação de cumplicidade e conivência de contrários defendida por Durand. "Para o colonialismo, esse vasto continente [África] era um antro de selvagens, uma região infestada de superstições e fanatismo, digna de desprezo, carregada de maldições divinas, lugar de antropófagos, lugar de negros" (FANON, 2005, p. 245). Desta forma, a África presente na América Latina, representada através dos escravos africanos com suas doenças, ritos e "possessões demoníacas" também era algo a ser combatido através da fé e do domínio cristão. A imagem do negro, inclusive em uma menina branca, era capaz de responsabilizá-la por todos os males que pudessem ocorrer onde esta estivesse.

Do Amor e Outros Demônios trata principalmente dos mitos que envolvem e amedrontam a sociedade através dos tempos e da história. A repercussão e poder do mal atrelado ao mito da menina branca que foi possuída pelos demônios africanos exatamente por ter sido entregue a eles por uma escrava. A criança filha do pecado e rejeitada pelos pais, filha de Olokum e entregue à morte pela autoridade cristã, acolhida pelos negros e vítima da crueldade do seu próprio clã, dos brancos que se diziam bons.

Através do imaginário humano, nos mais variados contextos, pode-se perceber que o estranhamento à cultura do outro é o responsável por produzir os tão temidos demônios presentes desde o surgimento das civilizações. A eterna disputa pela razão do que é certo ou errado na cultura ocidental tem marcado o cerne das maiores guerras ideológicas que se teve notícia até então. Com as religiões, poder norteador e temido pelas sociedades, não foi diferente. Em Do Amor e Outros Demônios, a situação escandalosa de um possível demônio que se apoderou de uma menina branca filha de marquês resultou em grande tragédia. E esta, semelhante a tantas outras, serviu apenas para "honrar" a consciência dos grupos hegemônicos.

Os meios usados no embate contra o diferente geralmente são os mesmos, o que muda com o decorrer do tempo são os personagens. Identidade e alteridade (representação da diferença) caminham juntas, uma depende da outra para existir, no entanto, a supremacia da verdade mostra quem domina e quem obedece. E claro, a mitificação do bem e do mal produz santos e monstros com objetivos bem definidos pelos que detêm o poder. 


\section{Bibliografia}

ARAÚJO, Maria Inês de. Do amor e outros demônios. Paroxismo, exorcismo e desamparo no romance de Gabriel García Márquez. Pulsional Revista de Psicanálise, ano XIII, n 134, p. 5-15. Disponível em: <http:// www.editoraescuta.com.br/pulsional/134_01.pdf>. Acesso em: 6 jun. 2012.

DURAND, Gilbert. A imaginação simbólica. Trad. Carlos Aboim de Brito. Lisboa: Edições 70, 1993.

DURAND, Gilbert. O Imaginário: ensaio acerca das ciências e da filosofia da imagem. $4^{\mathrm{a}}$ ed. Rio de Janeiro: DIFEL, 2010.

FANON, Frantz. Os Condenados da Terra. Trad. Enilce Albergaria Rocha, Lucy Magalhães. Juiz de Fora: Ed. UFJF, 2005.

FANON, Frantz. Pele Negra, Máscaras Brancas. Trad. Renato da Silveira. Salvador: EDUFBA, 2008.

LANDOWSKI, Eric. Presenças do outro: Ensaios de sociossemiótica. São Paulo: Editora Perspectiva, 2002.

MAGALHÃES, Antônio C. M. Identidade Cultural e Cristianismo em Textos de Gabriel García Márquez. In: Segundo Colóquio Latino-americano de Literatura e Teologia. Simpósios. Chile: 2008. Disponível em: < http:// www.alalite.org/files/chile2008/ponencias/Antonio\%20Magalhaes.pdf>. Acesso em: 20 abr. 2012.

SILVA, T. T. (org.). A produção social da identidade e da diferença. In -Identidade e diferença: a perspectiva dos estudos culturais.

Petrópolis, RJ: Vozes, 2000.

\section{Imagem}

Disponível em http://images.epilogue.net/users/monstarling/siervamaria.jpg. Consultada em 07/10/2012. 



\section{A demonização em A Conquista Espiritual (1639), de Antonio Ruiz de Montoya e na Festa de S. Lourenço (1587), de José de Anchieta}

Silvio Ruiz Paradiso (PG- UEL Capes/UEM) ${ }^{1}$

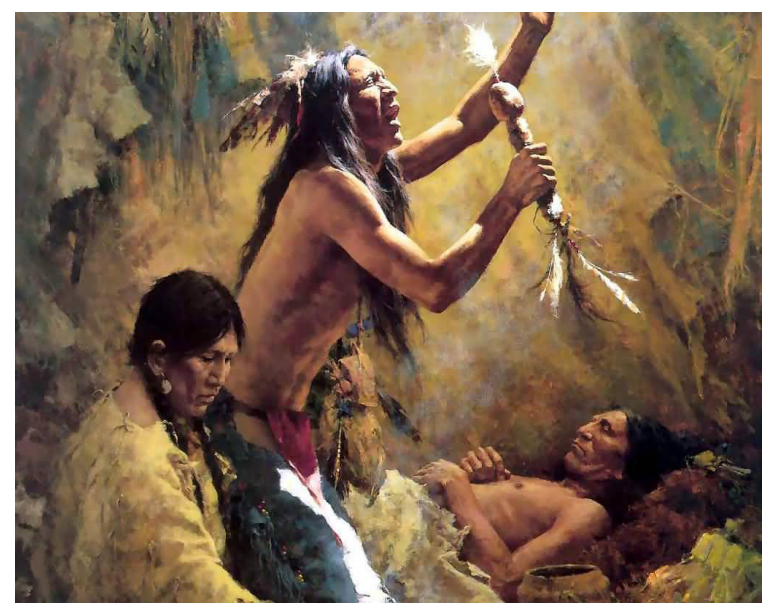

O cristianismo está intimamente ligado à expansão ultramarina e à colonização da América. A crença na supremacia europeia se baseava também na supremacia da religião cristã, afinal, para portugueses, ingleses e espanhóis, a colonização era, também, a expansão da única e verdadeira fé. Nesse sentido, Deus não apenas abençoava, mas tornava possível a expansão colonial. A missão religiosa foi um dos elementos mais importantes nos processos colonizatórios entre os séculos $X V$ e XX por todo mundo, em especial, no projeto colonial português e espanhol, com o padroado, por exemplo.

1 Doutorando pela Universidade Estadual de Londrina (UEL) em Estudos Literários/ Diálogos Culturais. Bolsista CAPES. Graduado em Letras Anglo-portuguesas pelo Centro Universitário de Maringá. E-mail: silvinhoparadiso@hotmail.com 
Embora não tenha sido o único aspecto importante, o processo de conversão foi fator decisivo para conquistas territoriais ou estratégias políticas. Em muitos casos, os missionários estavam entre os primeiros 'desbravadores' mandados às colonias. Sua ação ao conquistar corações e mentes, abria caminho para os demais conquistadores. Tal caminho, iluminado pela Sagrada Escritura, tinha êxito devido à conversão de chefes e reis das então 'novas' terras, resultando, por consequência, a conversão dos súditos e de toda a comunidade autóctone ali representada.

Pregar o cristianismo, isto é, a prática de prosélytus nasce da frase profética de Jesus no Evangelho de Marcos (16:15-16): "E disse-lhes: Ide por todo o mundo, pregai o evangelho a toda criatura. Quem crer e for batizado será salvo; mas quem não crer será condenado”. Os missionários cristãos se espalharam por todo mundo, subsidiados pelo projeto colonial. Nas caravelas, sacerdotes católicos e protestantes - em menor grau, quando na Ámerica do Norte e Caribe -, armados com Bíblias e com grande eloquência, dirigiam-se às terras imaculadas pela ideologia europeia, levando à frente a sentença predita por Jesus: "quem não crer será condenado". E a condenação não tardou a chegar para muitos ameríndios e africanos, que se recusaram a assimilar a nova religião trazida pelo colonizador.

Uma mentalidade medieval mostrou sua persistência na Península Ibérica e fez com que ideais "cruzadistas" estivessem presentes nos grandes empreendimentos marítimos. Por essa razão, a conquista da América está relacionada com dois signos da civilização cristã europeia: a cruz e a espada.

A palavra conversão vem do latim conversio, traduzindo o grego metanoia, que significa literalmente "ir sentido oposto" ou "mudar a mente". A conversão religiosa seria, basicamente, a adoção de uma nova religião que difere da anterior do converso. Pessoas se convertem a uma religião diferente por várias razões, incluindo: a conversão ativa por livre escolha, devido a uma mudança nas suas crenças pessoais; a conversão secundária; conversão no leito de morte; a conversão de conveniência e de conversão civil e conversão forçada.

A Igreja considera que a conversão exige internalização do novo sistema de crença, implicando um novo ponto de referência: a autoidentidade do converso. Isso implica em assimilação completa (língua, mitos, estrutura, hierarquia, ritos) da nova religião e recusa da antiga. Entretanto, Machado (1994) aponta que "em situações de desorganizações de 
esquemas culturais de interpretação", isto é, os choques culturais, que acontecem frequentemente nos ambientes coloniais, a conversão não é feliz nessa reinterpretação hegemônica da sociedade autóctone. Neste contexto falho de reinterpretação, repleto de lacunas e conflitos identitários, o fenômeno da conversão e catequese podem não apresentar o sucesso pretendido, gerando exclusões, conflitos, desestruturas sociais e em especial a demonização.

A demonização é fruto, quase sempre da alteridade e da não aceitação e da nova fé e é imposta. No caso da colonização portuguesa da América, os grandes protagonistas desse processo de rejeição são os pajés e os índios inimigos das reduções aliadas, isto é, o outro demoníaco.

No presente artigo, analisar-se-á a demonização dos nativos analisados sob a perspectiva pós-colonial em duas narrativas: A Conquista espiritual (1639) do missionário peruano Antonio Ruiz de Montoya, e Na festa de S. Lourenço (1587), do jesuíta José de Anchieta.

\section{Conversão em $A$ conquista espiritual (1639), de Antônio Ruiz de Montoya}

Em 1585, em Lima, no Peru, nascia Antonio Ruiz de Montoya, um padre jesuíta que escreveria a primeira gramática escrita da Língua Guarani - o Tesoro de la lengua guaraní, publicado em 1639 em Madri, na Espanha. Entrou na Companhia de Jesus em $1^{\circ}$ de novembro de 1606, e no mesmo ano, acompanhou o Padre Diego Torres, o primeiro provincial do Paraguai, para tal missão.

Junto com os padres Cataldino e Mazeta, o peruano fundou as reduções de Guairá, trazendo uma série de tribos silvícolas para os seios da Igreja Católica, e afirma ter batizado pessoalmente mais de cem mil índios. Como chefe das missões, Montoya tinha a encargo de 1620 a "redução" no curso superior e médio do rio Paraná e do rio Uruguai, acrescentando mais treze "reduções" para as 26 já existentes. Quando as missões de Guairá foram ameaçadas pelas incursões dos paulistas do Brasil em busca de escravos, os padres Mazeta e Montoya resolveram transportar os índios 'convertidos' (um total de 15 mil), por água se deu com a ajuda de 700 balsas e canoas, mostrando sua convicção na empreitada. 
Montoya em 1637 (em nome do governador, do Bispo do Paraguai e dos chefes das ordens) apresentou uma reclamação formal a Filipe IV da Espanha, sobre a política portuguesa de envio de expedições às regiões vizinhas, na América espanhola. Montoya também foi o padre jesuíta encarregado de se queixar diretamente ao rei de Portugal, sobre os bandeirantes paulistas que atacavam as missões jesuítas em busca de índios para serem vendidos. Toda sua catequese foi escrita por ele mesmo, em a Conquista Espiritual. Enquanto escrevia, vivia no Paraguai, onde outros jesuítas mantinham inconteste a jurisdição sobre os indígenas no Vice-Reinado do Peru. Após o retorno à América, Montoya faleceu em 1652.

\section{Montoya e os pajés/caciques Neçu, Taubici, Guirabera, Maracanã e Artiguaye}

A divisão maniqueísta que se formava entre toda população das margens dos rios Paraná, Uruguai e do rio Tape era inegável. O fato se dava na clara divisão: bem e mal, fomentada pelos jesuítas, cujas legiões dessa guerra se formavam entre o clero e os índios convertidos contra pajés e xamãs e os índios rebeldes, liderados por Jesus e pelo diabo respectivamente.

A Igreja Católica espanhola entrou em território sul-americano, junto com os demais colonizadores espanhóis, encabeçados pelo conquistador Pedro de Medonza y Luján, em 1535, na região da Prata. Lozano (1912) observa que com a Igreja fixada, anos depois, o bispo de Tucumán, Francisco de Victoria, convida a Cia. de Jesus a fazer parte da região, apesar desta já possuir algumas reduções controladas pelos franciscanos (VIEIRA \& SOUZA, 2004, p.3). Os missionários chegam ao Paraguai e Peru entre 1587-1588, encontrando uma gigantesca mãe-natureza, a qual abrigava duzentos mil índios guaranis - um local muito propício para a catequese dos então "selvagens" do Novo Mundo.

O catecismo guarani, utilizado em toda a província, foi elaborado pelo frei Luis de Bolaños e oficializado em 1603 pelo Sínodo de Assunção (VIEIRA \& SOUZA, 2004, p.3). Bolaños havia escrito um dicionário e uma gramática do guarani, facilitando em muito o êxito da evangelização 
entre tribos da região. O jesuíta Antônio Ruiz de Montoya possuía uma definição própria para as reduções, locais com "diligencia de los padres a poblaciones grandes y a vida política y humana, a beneficiar algodón con que se vistan" (MONTOYA, 1892, p.29), isto é, para Montoya, as reduções não só cristianizaria os índios, mas os "civilizariam".

Em 1604, com as bênçãos do Padre Aquaviva geral da Companhia de Jesus, em Roma, e o aval de Felipe III, formou-se a província jesuítica do Paraguai. Montoya, todavia, iria chegar a Guairá oito anos depois, em 1612. Antonio Ruiz de Montoya iria descrever suas ações e narrar todos os acontecimentos em Guairá, no seu texto Conquista Espiritual hecha por los religiosos de la Compañia de Jesús, en las Provincias del Paraguay, Paraná, Uruguay y Tape (1639). No texto, focamos nos obstáculos dessa conquista espiritual dos jesuítas: os caciques e pajés.

Para os espanhóis, caciques e pajés eram sinônimos. Esse reducionismo se baseava na ideia de denominação dos chefes indígenas americanos, difundida por portugueses e espanhóis. Cacique vem do arauaque (Haiti) cachique, "chefe político", castelhanado cacique. Para os guaranis, a denominação empregada para seus principais é mburovixá. Já o pajé é um termo tupi referente a uma pessoa de destaque, portadora de poderes ocultos ou orientadores espirituais. Segundo o dicionário: "chefe espiritual dos índios, misto de feiticeiro e médico” (LUFT, 2001, p.497).

Com uma enorme cruz fincada no centro da redução, o território para a guerra espiritual estava preparado - pajés e jesuítas conviviam na mesma zona de contato, outremizando ${ }^{2}$ um ao outro, afinal, os pajés contestavam o poder dos clérigos, acreditando serem eles destruidores de uma cultura religiosa ancestral, enquanto para os jesuítas, esses, que insistiam em não se converter eram (na concepção colonial) seres sem alma, trabalhadores do demônio, a fim de atrapalhar os planos da salvação daquela gente - a guerra estava formada.

2 Transformar em outro. O conceito de outremização foi cunhado por Gayatri Spivak (1985) e descreve o processo de "transformar" o sujeito colonial em outro, a partir dos pressupostos de superioridade do sujeito metropolitano. A outremização é particularmente muito próxima da objetificação, já que, segundo Spivak (apud Ashcroft et al.) a criação de outros, nada mais é que a criação de pequenos objetos do/para o imperialismo , no qual o indivíduo outremizado perde sua agência e sua subjetividade (PARADISO, BONNICI, 2012). 
A dialética nas reduções baseava-se na divisão dos índios em convertidos e não convertidos. Os grupos, em constante confronto, representavam, como o próprio Ruiz de Montoya refere-se, a imagem do Juízo Final: "uma representação do Juízo Final, como em geral se pinta. Assim, figurava ela [a redução] e os Anjos defendendo as almas, e os demônios atacando-as. Enxergou que faziam o papel de Anjos os da Companhia" (MONTOYA, 1985, p.30).

Aqueles que se recusavam se curvar perante a fé cristã eram constantemente demonizados e objetificados, a fim de garantir aos índios convertidos que estes fizeram a escolha pelo bem.

Encabeçando os rebeldes, estavam os líderes religiosos indígenas, os pajés e caciques, empenhados em desmoralizar os padres e a doutrina cristã. Os pajés eram outremizados pelos religiosos, recebendo adjetivos variados como: miserável, familiar ao diabo, feiticeiros, magos, fingidos, entre outros. Por não estarem convertidos ao propósito da fé católica, se armavam com estratégias como paródia e mímica (BHABHA, 1998), o revide e a subjetificação.

Dentre os "caciques", o mais problemático aos olhos da conquista espiritual, era Taubici, que segundo Montoya, significava "diabos em fila ou fileira de demônios [...]" (MONTOYA, 1985, p.48), um claro exemplo de demonização deste por parte do padre peruano.

O pajé ${ }^{3}$, mesmo salvando a vida dos inacianos, já era considerado como um indivíduo 'mau':

Esse homem recebeu-nos bem e, embora mau, livrou-nos da morte, porque naquela noite de nossa chegada alguns índios queriam matar-nos e, ainda que estivessem dispostos a fazê-lo, pareceu-lhes que não o deviam sem consulta sua. A isso respondeulhes ele: 'Se vós quiserdes matar os padres, fazei-o, mas eu não vou meter-me nisso!' Este desdém bastou para que não nos tirassem a vida, quando a esse respeito confabulavam,... (MONTOYA, 1997: 51. Grifo meu).

3 Alguns como Taubici eram caciques e pajés simultaneamente. 
As estratégias de Taubici eram variadas, já que contestava a liderança dos padres. Uma delas era o vaticínio mediante os transes que, quando confirmados, aumentava seu prestígio e confiança dentro da comunidade guarani. Uma das mais famosas profecias de Taubici foi sobre as consequências do furto de cana-de açucar por alguns índios; Taubici vaticinou aos reclamantes do furto, que os que roubaram seriam castigados "pela enfermidade de câmeras", isto é, diarreia. O próprio Montoya confirma a realização do fato pouco tempo depois (MONTOYA, 1997: 52). Entretanto, argumentava que os poderes de Taubici eram oriundos de sua fraternidade com o demônio: "[...] Ordenava descobrir alguma parte do telhado de sua casa, e era lá por onde houvesse de entrar o mau espírito. Sobrevinham então a esse miserável determinados desmaios, e as mulheres o ajudavam, segurando-lhe os braços e a cabeça, ao passo que ele fazia trejeitos e meneios ferozes" (MONTOYA, 1985, pp. 48-49).

Montoya percebeu o apego dos índios guaranis às visões, transes e premonições, fazendo discursos para a conversão, alertas para esses embustes diabólicos; até porque, o transe, o vaticínio e a possessão tornam-se armas políticas na boca do colonizado (PARADISO, 2011). O que não critica, porém, são os mesmos fenômenos vindos de sua gente, os cristãos, que também podiam ter seus sonhos premonitórios:

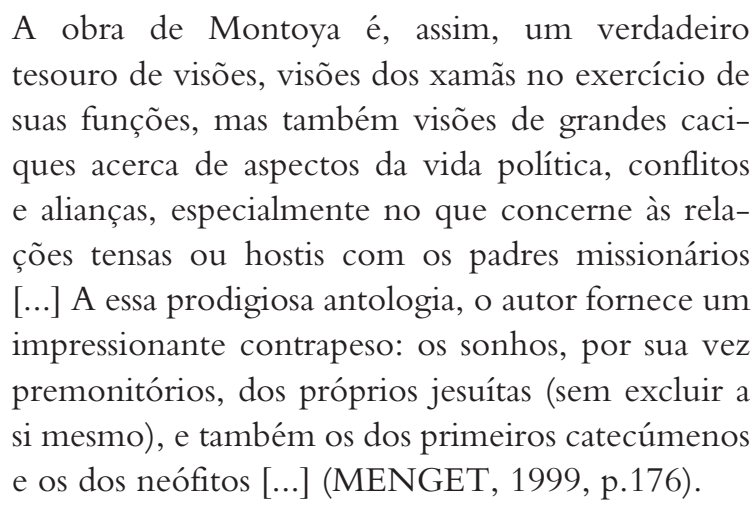

As visões dos não conversos deveriam ser repudiadas e demonizadas, para que as visões dos cristãos pudessem ser exaltadas. A coroação da sacralidade das visões cristãs veio com o "acerto" de uma profecia ocorrida em favor dos padres, no dia de Corpus Christi, em que Taubici decidiu convocar alguns índios para o encontro com outros não-conversos, ignorando a missa e a procissão do dia. O fato desencadeou a 
advertência do jesuíta Masseta, que os dissidentes iriam ser castigados pela falta. Aconteceu que, por coincidência, o grupo fora atacado por índios rivais, sedentos de vingança contra Taubici, que assassinara um membro daquele grupo tempos atrás. Era o fim do pajé (MONTOYA, 1997, p.52).

Outra pedra nos sapatos dos sacerdotes era Neçu, "o maior dos caciques que aqueles 'países' conheceram” (MONTOYA, 1997, p.223). Além disso, era caracterizado por suas "artimanhas, embustes e magias, com as quais enganava aquela gente bárbara” [...] consequência do furor em que o demônio ardia (MONTOYA, 1997, p.223). A conquista Espiritual narra uma das estratégias de $\mathrm{Neçu} \mathrm{-} \mathrm{a} \mathrm{fim} \mathrm{de} \mathrm{arrebanhar} \mathrm{os}$ índios já convertidos - usava os "paramentos litúrgicos" sacerdotais para se assemelhar aos jesuítas: "Neçu, de sua parte e para mostrar-se sacerdote, conquanto falso, revestiu-se dos parâmetros litúrgicos [...]. E fez trazer em sua presença as crianças, nas quais tratou de apagar com cerimônias bárbaras o caráter indelével, que elas pelo batismo tinham impresso em suas almas [...]" (MONTOYA, 1997, p.228). Neçu se apropriava das ideias ritualísticas católicas, subvertendo-as, afinal, sabendo dos ritos cristãos, usava o inverso para anulá-los; enquanto os religiosos focavam no batismo, Neçu incentivava o "desbatismo", lavando os recém-batizados dos pés à cabeça (no sentido inverso da queda d'água cristã), raspava a língua das crianças que "haviam saboreado o sal do espírito sapiencial", e as costas dos que foram ungidos por santos óleos (FAUSTO, 2005, s/p).

Todavia, quem outrora era demonizado, a partir da conversão passa a se tornar exemplos, homens virtuosos e mártires. O cacique e pajé Guirabera, por exemplo, antes chamado mago e canibal, que ardia em furor e desejo a devorar o padre Montoya (MONTOYA, 1997, p.137) e que parodiava missas no meio da mata, substituindo hóstia e o vinho, por bolo de mandioca e vinho de milho, se rendia à verdade cristã. Montoya ao usar o adjetivo "grande" ante ao termo feiticeiro", antecipava a conversão e o êxito de recuperação deste.

O sucesso de conversão também se deu ao cacique Tambavê, que "tão grande foi sua eficácia em pregar a Cristo que, transformado em Paulo, contribui na conversão de muitos gentis" (MONTOYA, 1997, p.231) ou a Roque Maracanã, "un honrado cacique, deseoso de oír las cosas de su salvación” (MONTOYA, 1892, p.47), que agora catequizado, isto é, 
no "lado bom" fora perdoado por ter assassinado um mago no rio, com uma pedra amarrada no pescoço. $\mathrm{O}$ assassinato de um ímpio pelas mãos de um índio cristianizado era visto não como "crime", mas como uma punição de Deus aos infiéis.

Contudo, alguns casos de conversão culminavam com o fracasso, como Miguel Artiguaye (Miguel, devido à conversão) que se apropria do termo "demônio" e de ideias cristã (imortalidade d'alma) para revidar o discurso dos jesuítas. Artiguaye chama os padres de demônios, que destroem a cultura ancestral (MONTOYA: 1892, 57), além de ironizar as ameaças dos padres com a frase: "no me matareis el alma por ser imortal" (MONTOYA, 1997: 235).

Assim, Artiguaye, Taubici, Neçu, Guirabera, Maracanã e Tambavê são exemplos dos resultados múltiplos da conversão no texto $A$ conquista Espiritual, de Antonio Ruiz de Montoya, um fenômeno que dividiu a América do Sul em paraíso e inferno, com seus respectivos habitantes.

\section{Demonização em Na Festa de São Lourenço, de José de Anchieta (1587)}

Cognominado de Apóstolo do Brasil, José de Anchieta foi um sacerdote jesuíta espanhol, nascido em San Cristóbal de la Laguna, nas Canarias, no dia 19 de março de 1534. Até 1548 viveu com a família, que abandonara para poder estudar Filosofia no Real Colégio das Artes e Humanidades, em Coimbra. Sua ida a Portugal foi consequência de sua ascendência judaica, uma vez que em Espanha, a Inquisição era muito mais rigorosa. Em 1551 decide entrar na ordem jesuíta como noviço.

Com a necessidade de atividades de evangelização no Brasil, o provincial dos Jesuítas na colônia, padre Manuel da Nóbrega, solicitou ao então provincial de todo ordem na época, Simão Rodrigues, uma indicação. Este por sua vez, indicou, entre outros, José de Anchieta, que chegou ao Brasil em 13 de junho de 1553, recebendo a incumbência de administrar e construir o Colégio. Em sua estadia, Anchieta aprendera o tupi, que se somava com os outros três idiomas que dominava: castelhano, latim, e português. O jesuíta além de escrever a primeira gramática desta que, na América Portuguesa, seria chamada de "língua geral", escreveu poemas líricos, cartas sobre filologia e várias peças teatrais. 
Com elenco formado por indígenas e portugueses, o auto Na festa de S. Lourenço ou apenas $O$ auto de São Lourenço, foi representado no átrio da capela do mesmo santo, em 10 de agosto de 1857, em idioma tupi, castelhano e português.

A peça gira em torno do martírio de São Lourenço, queimado por Valeriano, censor do Imperador romano Décio. Literatos modernos a dividiram em 5 atos ou cenas: [1] música de abertura, em castelhano, sobre o martírio do santo; [2] cena em tupi, sobre os três demônio índio controlando a comunidade;[3] demônios-índio punindo os romanos pelo martírio de s. Lourenço, cena em tupi e português; [4] cena com mensagens de personagens alegóricos, como o 'amor de Deus' e o 'temor de Deus', cena em português e castelhano e [5] resolução do conflito dramático, dança e música em tupi. O próprio ato 4 , sintetiza bem com suas alegorias, o binarismo necessário para o entendimento nativo acerca do pecado e absolvição, bem e o mal, inferno e Paraíso e Deus e o diabo.

Estudiosos (MARTINS,1948) consideram o auto de São Lourenço a melhor peça de Anchieta (apud MOUTINHO, 1999, p.196) "Longa sem ser monótona , simpática apesar de sátira, capaz, sem dúvida, do êxito que lhe atribuíram na época, e ainda hoje digna de atenção e interesse".

\section{Santos e demônios na América de Anchieta e dos índios tupis}

A catequese jesuítica se baseou em um plano de colonização comum no mundo colonial: o deslocamento de vários índios em locais menores, as aldeias jesuítas, chamadas posteriormente de reduções. As reduções, nome advindo do termo 'reduzir' sendo "usado para representar a submissão do índio ao cativeiro (BOGONI, 2009: 135), eram estruturas de aldeiamento o qual evitava a dispersão dos índios e do contato com os encomederos e/ou bandeirantes. Para Necker (1979) e Melià (1978), as reduções surgiram como "Projeto político de integração do ameríndio dentro do sistema colonial, transmitindo-lhe o cristianismo e a civilização, fortemente eurocêntricos" (apud BOGONI, 2009: 136). As reduções eram grandes 'palcos' para o teatro cristão. 
Havia uma necessidade de orientar a catequese, segundo os costumes e tradições indígenas. O Padre Manuel Nóbrega sabia das funções didáticas e pedagógicas do teatro, além de sua eficácia para doutrinamento teológico. Desta forma, as origens do teatro brasileiro estão intimamente ligadas ao início da catequese jesuítica, cuja autoria perpassa a Navarro, Nóbrega e principalmente, Anchieta (MOUTINHO, 1999, p.191), que foi incumbido de organizar a dramaturgia nas reduções.

O texto, trilíngue de Anchieta baseava na ideia de que os demônios advogavam pelos terríveis hábitos dos índios: o cauim ${ }^{4}$, o fumo, o curandeirismo e a poligamia, e tais demônios eram nada mais que os próprios índios que, todavia, não aceitavam a proposta civilizadora e messiânica dos portugueses cristãos. O demoníaco em Guiaxará, principal de Cabo Frio, é caracterizado a partir da sua não aceitação dos costumes europeus, isto é, costumes cristãos: "Esta virtude estrangeira/Me irrita sobremaneira./ Quem a teria trazido,/com seus hábitos polidos/estragando a terra inteira?" (ANCHIETA, 2012, p.4. Grifo meu).

Essas virtudes e hábitos trazidos pelos jesuítas visavam, segundo a crença dos religiosos, 'civilizar' os índios, destituindo-os de uma imagem tida como bestial, imagem essa oriunda da mentalidade colonial europeia frente aos povos de outras terras. Os índios-demônios são moldados a partir do estereótipo do homem-besta de Aristóteles, em Política, 1254 ab. (apud BONNICI, 2000, p.62), e recriados sob os resquícios dos monstros medievais e das bestas do Novo-Mundo.

Em contrapartida, a imagem idealizada apresentada pelo Anjo e pelos mártires cria a polarização entre o bem (civilizados) e o mal (selvagens).

A demonização é uma estratégia de corrigir hábitos autóctones que, de acordo com a mentalidade religiosa de Anchieta só cabia ao demônio, o deus estrangeiro5: "bebemos dias inteiros./Adornaram-se festeiros./Me abraçaram, me hospedaram,/das leis de deus estrangeiro" (ANCHIETA, 2012, p.7).

4 Cauym ou Cauim é uma bebida alcoólica tradicional dos indígenas brasileiros, feita através da fermentação da mandioca ou do milho.

5 Devemos entender que o discurso de Aimberê é escrito por Anchieta. Logo, o deus estrangeiro a quem o índio-diabo se refere não é o Deus cristão, mas sim o demônio, que habita outras tribos e não mais entre os tupis, agora acolhidos pelo cristianismo. 
Desta forma, apesar dos diabos não serem caracterizados fisicamente (com exceção de sabermos que possuem chifres, garras e tridentes [ANCHIETA, 2012, p.23], ou seja, uma estereotipada imagem do diabo medieval), são caracterizados a partir de um viés cultural, ou seja, a demonização se dá a partir do canibalismo, no excesso, na embriaguês, na dança, na poligamia, etc. (MELLO \& SOUZA, 1993, p.33), como percebemos na fala de Aimberê: "Os jovens que censuravam/ com morubixaba dançam,/ e de comer não se cansam,/ e no cauim se lavam,/ e sobre as moças avançam" (ANCHIETA, 2012, p.20). Esse excesso é a marca recorrente na construção dos demônios-índios: Meu sistema é o bem viver./[...]Boa medida é beber/cauim até vomitar. [...] Beber caium até vomitar,/ ser beberrões, embriagar (ANCHIETA, 2012, II, pp.5 e 6).

O mal é corporificado em três indígenas: Guiaxará, Aimberê e Saravaia, os dois primeiros, nomes de índios conhecidos pelos portugueses na época. Em suas cartas, Anchieta revela que estes índios tamoios lideraram com seus pares um apoio aos franceses contra os portugueses, numa batalha de 1567. Todavia, os portugueses liderados por Mem de Sá e Estácio de Sá venceram com auxílio dos índios temiminós. Já Saraiva ou Saravaia, seria a versão tupi 'criada' por Anchieta para o termo selvagem (BRAGA-PINTO, 2003, p.95). Desta forma, o diabo será corporificado em nativos que representam a não aceitação política e religiosa portuguesa.

Os demônios-índios Guaixairá, Aimberê e Saraiva no início do Ato II, demonstram discursivamente que têm poderes sobre os índios, e descrevem todos os terríveis pecados que eles os submetem. Entretanto, estes pecados são os elementos coesão sócio-cultural indígena (COSTA, 2007, p.108), notadamente as cauinagens e os rituais de antropofagia, sobre os quais se alicerçavam a cosmogonia desse povo. A demonização cultural é clara, quando Aimberê avalia que os rituais vêm de épocas antigas, alcançando velhos, moças e jovens, isto é, que fazem parte da identidade do povo tupi: "Todos os que aqui habitam/desde épocas mais antigas,/velhos, moças, raparigas,/submissos aos que lhes ditam/nossas palavras amigas./Vou contar todos seus vícios, /[...]" (ANCHIETA, 2012, p.19. Grifo meu). 
Ao por tal discurso na boca do demônio-índio, Anchieta já antecipa sua posição (e da Igreja) sobre a cultura autóctone, que independente de ser um elo identitário, tais práticas devem ser combatidas, afinal, os índios só serão salvos caso 'deixem de ser' índios. Essa é a ideia central de todo segundo ato: a orbis christianus entra em choque com a visão cosmogônica dos indígenas, objetivando provocar identificação e rejeição aos hábitos e costumes dos não catequizados e inimigos da coroa portuguesa.

É clara a oposição dos demonizados contra os missionários e seu projeto civilizador: "Vêm os tais padres agora/ com regras fora de hora/ prá que duvidem de mim./ Lei de Deus que não vigora" (ANCHIETA, 2012 , p.6). Ainda, a fala de Aimberê traz a mensagem que as regras civilizatórias trazidas pelos religiosos são regras divinas. Quem as cumpre está com Deus, quem as desobedece está contra Ele.

Na mentalidade religiosa, Anchieta faz uma analogia entre a dança, o folgar e o beber à selvageria, logo, à animalização:

O estatuto selvagem. Guiaxará, [...] identifica-se com boicininga (cascavel), jaguar, andirá-guaçu (morcego); Aimberê confunde-se com jiboia, taguató (gavião), tamanduá. S. Sebastião e o Anjo chamam Saravaia de rata, gambá, morcego, larva, cururu( sapo) e sanguessuga. Suas ações são estereótipos medievais de demônios metamorfoseados em animais. (BONNICI, 2000, p.65)

De acordo com Certaeu (1982) a produção de sujeito visa a produção de nomes, que só adquirem sentidos quando são excessivamente adjetivadas e predicadas (p.259). Desta forma, não é somente a zoomorfização que os constrói, os índios inimigos são adjetivados de forma negativa. Guaixará, por exemplo, é nomeado como embriagado, antropófago e matador (ANCHIETA, 2012, p.15). O vocabulário anchietano estrutura-se para dar significado ao processo de demonização. Contudo, a estrutura da peça também (re)cria novos significados, quando expõe o lirismo e a superioridade espiritual do europeu na língua vernácula dos religiosos em cena musicadas em oposição à língua nativa em cenas com os demônios e de conflitos: "A língua tupi, portanto, está a serviço da maldade, da raiva, da perversão e do castigo, em contraste com o conteúdo cristão e singelo transmitido em língua castelhana" (BONNICI, 2000, p.64). 
A demonização sempre está oposta a divinização e civilidade cristã -europeia no Auto de S. Lourenço. A única saída para essa bipolarização, que levaria uns ao Paraíso e outros ao Inferno seria homogeneiza-los, isto é, cristianizar todos, sem exceção, pois nas falas de S. Lourenço apenas a confissão e a comunhão católica pode curar e depurar a alma dos índios da perdição. (ANCHIETA, 2012, p.21). Tal mensagem salvífica é dada por "Bastião, de flechas crivado" e "O file Capitão de Deus" (ANCHIETA, 2012, p10), respectivamente, S. Sebastião e S. Lourenço.

Assim, a punição dos três diabos no inferno - "Guaixará seja queimado,/Aimbirê vá para o exílio,/Saravaia condenado!” (ANCHIETA, 2012, p.30) - representa a queima e aniquilação de todo antigo costume dos índios, a filiação política dos tamoios bem como a padronização da cultura cristã.

Finalmente, o outro demoníaco foi sepultado no inferno, cujo fogo acultural fora aceso na chegada dos missionários às Américas.

Ao analisarmos o outro em textos pós-coloniais, sempre esperamos um embate ou uma polarização frente ao Outro colonizador. Nas literaturas catequéticas observamos inúmeras estratégias do colonizador a fim de alicerçar sua considerada cultura superior, sendo a conversão e demonização as mais comuns.

No texto do missionário peruano Antonio Ruiz de Montoya, $A$ Conquista espiritual (1639) observa-se a incisiva resistência dos pajés/ caciques Neçu, Taubici, Guirabera, Maracanã e Artiguaye contra a dominação espiritual cristã. Já em Na festa de S. Lourenço (1587), do jesuíta José de Anchieta, o teatro é pano de fundo da apresentação dos índios rebeldes Guaixará ,Aimbirê e Saravaia. Em ambos os textos os jesuítas e os conversos fazem parte de um propósito salvífico, que visa à salvação da alma, bem como a civilidade dos autóctones. Entretanto, nos dois textos é clara a construção diabólica daqueles que não aceitam esse propósito eurocêntrico, processo chamado demonização.

Por fim, as práticas culturais indígenas, tanto dos guaranis, como a dos tupis e demais etnias, como a dança, folguedos, adornos, o fumo, a feitiçaria, a poligamia, e glutonia são lidas pela religião cristã como práticas pecaminosas, que somente a conversão e aceitação da fé católica podem apagar. Assim, o ambiente colonial, frequentemente, a aculturação torna-se o fenômeno resultante da prática 'pedagógica' que é o demonizar. 


\section{Bibliografia}

ANCHIETA, Pe. J. de. O auto de São Lourenço. (versão on-line).

Disponível em: http://virtualbooks.terra.com.br/freebook/port/download/ Auto_de_Sao_Lourenco.pdf. Acesso em 03 jun. 2012.

BHАВНА. H. O local da Cultura. Belo Horizonte, Humanitas: Ed. UFMG, 2005.

BOGONI, R. Resistência do sujeito colonial na região guaranitica do Paraná, em Conquista Espiritual (1639), de Antonio Ruiz de Montoya. In: BONNICI,

T. Resistência e intervenção nas literaturas pós-coloniais. Maringá: EDUEM, 2009. P.

BRAGA-PINTO, C. As promessas da história: discursos proféticos e assimilação no Brasil colonial (1500-1700). São Paulo: EDUSP, 2003.

COSTA, P. E. da S. Do sensível ao inteligível - $\mathbf{O}$ auto de $\mathbf{S}$.

Lourenço. Dissertação de Mestrado, UFPB, João Pessoa, 2007, 201p.

FAUSTO, C. Se Deus fosse jaguar: canibalismo e cristianismo entre os Guaranis (séculos XVI-XX). In: Mana, Rio de Janeiro, v. 11, n. 2, 2005, p. 385-418.

GREENBLATT, S. Possessões Maravilhosas: o deslumbramento do Novo Mundo. São Paulo: EDUSP, 1996.

LUFT, C. P. Minidicionário Luft. 20ª Ed. $6^{\text {a }}$ impressão. São Paulo: Ática, 2001.

MACHADO, G. J. C. A Conversão Religiosa. nov/94. Disponível em: http:// www.urisan.tche.br/ cienciadareligiao/artigos/artconversao.htm. Acesso em 06 out. 2011 [1994].

MARTINS, M. de L. de P. Auto representado na festa de São Lourenço, de José de Anchieta. Museu Paulista, boletim I, São Paulo, ano I, documentação linguística 1, pp138. [peça triligue do séc. XVI, transcrita, comentada e traduzida do tupi por Maria de Lurdes de Paula Martins], 1948.

MELLO \& SOUZA, L. Inferno atlântico. São Paulo: Companhia das Letras, 1993. 
MENGET, P. A política do espirito. In: NOVAES, A.(org) A Outra Margem do Ocidente. São Paulo: cia. da letras, p.p. 167-180. 1999.

MONTOYA, A. R. de. Conquista espiritual feita pelos religiosos da Companhia de Jesus nas Províncias do Paraguai, Paraná, Uruguai e Tape (1639). $2^{\mathrm{a}}$ ed. Brasileira. Porto Alegre: Martins Livreiro Editor, 1997. . Conquista espiritual. Porto Alegre: Martins Livreiro,

1985.

Conquista espiritual hecha por los religiosos de la Compañía de Jesús em las provincias del Paraguay, Paraná, Uruguay y Tape. Bilbao: Imprenta del Corazon de Jesús, 1892.

MOUTINHO, M. Pe. Bibliografia para o IV centenário da morte do beato José de Anchieta [ 1597-1997], v.1. Ed. Loyolas: São Paulo, 1999.

PARADISO, S. R. A Possessão como ambivalência colonial. Identidade e resistência na religiosidade africana em $O$ outro pé da sereia. In: Nau Literária (UFRGS), 2011.

PARADISO, S.R; BONNICI, T. Objetification and Othering in Is there nowhere else where we can meet? (1951), by Nadine Gordimer In: Acta Scintiarum

Language and Culture, v. 34, n. 2 (on line), 2012.

VIEIRA, C. M. N.; SOUZA, N. M. O enfrentamento entre indígenas e o colonialismo luso-espanhol no Itatim $(\mathbf{1 6 3 0 - 1 6 5 9 )}$ in: Anais do XVII Encontro Regional de História - O lugar da História. ANPUH/SPUNICAMP. Campinas, 6 a 10 de setembro de 2004. Disponível em http://www.anpuhsp. org.br/sp/downloads/CD\%20XVII/Paineis/Carlos\%20 Magno\%20Naglis\%20 Vieira.pdf Acesso em 03 jun. 2012[2004].

\section{Imagem}

Disponível em http://t3.gstatic.com/images?q=tbn:ANd9GcTSHP6GEz4xlYfqKJE2-MO5VRoAsqgyi4NPt-YxO8Fp3P7Z254U. Consultado em $07 / 10 / 2012$ 


\section{Configurações do mal no romance Caim, de José Saramago}

Hudson Marques da Silva (UEPB/IFPE) ${ }^{1}$

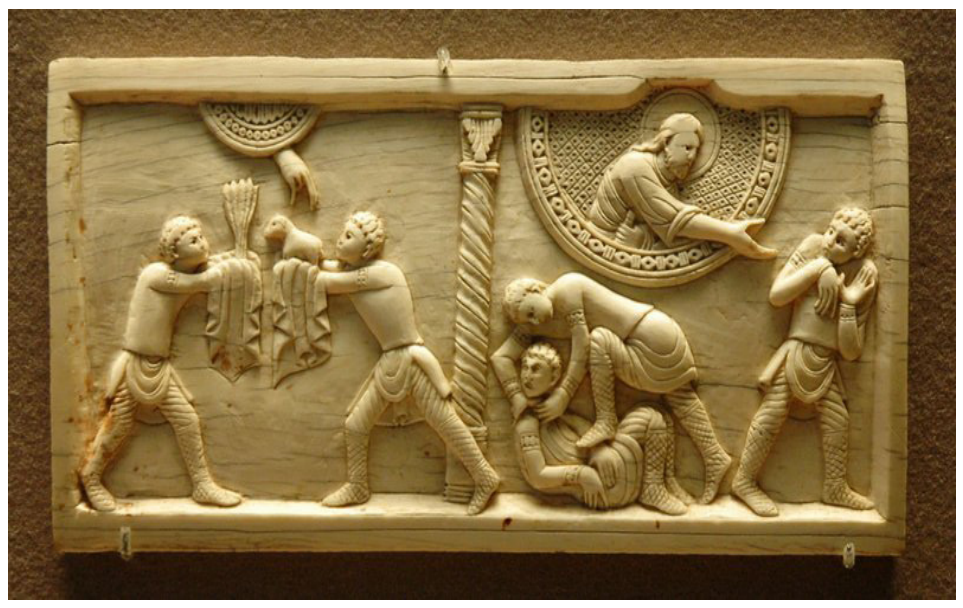

A obra literária Caim, o último romance de José Saramago, publicado em 2009, apresenta uma forte relação intertextual com alguns mitos do Antigo Testamento bíblico, o que a torna um palimpsesto. E isso se dá tendo em vista que "[...] o discurso não se constrói sobre o mesmo, mas se elabora tendo em vista o outro.”, como diz Eli Brandão (2008, p. 94). Desse modo, em uma perspectiva distinta e confrontante das interpretações eclesiásticas tradicionais, o romance saramaguiano remonta os seguintes mitos: Adão e Eva, Caim e Abel, Abraão e Isaac, a Torre de Babel, o encontro de Moisés com Deus no Monte Sinai, a destruição

1 Mestre em Literatura e Interculturalidade pela Universidade Estadual da Paraíba e Professor do Instituto Federal de Educação, Ciência e Tecnologia de Pernambuco - campus Belo Jardim. 
das cidades de Sodoma e Gomorra e, por fim, o contexto do dilúvio e a Arca de Noé, destacando, a partir da personagem caim, questionamentos sobre as ações de deus.

O romance Caim, assim como O Evangelho Segundo Jesus Cristo, de 1991, não foi bem aceito pela comunidade cristã, principalmente, pelos católicos portugueses, devido a seu caráter irônico, crítico e questionador em relação aos textos bíblicos originais, sobretudo no que se refere às ações de Deus. Em entrevista, Saramago (2009b) chegou a declarar:

A Bíblia é um manual de maus costumes, um catálogo de crueldade e do pior da natureza humana [...] Sem a Bíblia, um livro que teve muita influência em nossa cultura e até em nossa maneira de ser, os seres humanos seriam provavelmente melhores.

Contudo, vale salientar que este artigo comenta o texto de José Saramago e não os textos bíblicos. Portanto, como declara Antonio Carlos Magalhães (2008a, p. 15), Deus é um “[...] personagem literário, que, como qualquer outro personagem, cresce ou diminui à medida que dialoga com outros personagens."

Com base nessas premissas, o presente estudo propõe um diálogo acerca desses questionamentos perante as ações do Deus personagem, que neste romance surge como um ser antropomórfico, isto é, um Deus com atitudes e características humanas, portanto, passível a cometer erros, injustiças e até crueldades.

Enquanto re-escritura literária, o romance apresenta uma modificação na ordem cronológica dos mitos em relação aos textos bíblicos originais, além de uma estilística própria do autor, cujos sinais de pontuação não seguem o modelo proposto pela norma padrão: locais em que se grafariam ponto final (em fim de sentenças) e travessões (introduzindo falas de personagens), Saramago opta pelas vírgulas, promovendo uma confluência em que a voz do narrador e a voz das personagens se confundem. Além disso, identifica-se que os nomes de personagens e lugares cujas primeiras letras, normativamente, são grafadas em maiúsculas por representarem substantivos próprios, no romance aparecem em minúsculas. Por um lado, poder-se-ia presumir que isso se dá porque esses nomes, etimologicamente, possuem um significado, ou seja, não 
são nomes próprios. Por exemplo, a palavra adão, em hebraico $\mathbf{T}_{z}$ significa "terra vermelha" ou "homem vindo do barro"; eva (I-l) significa "vivente"; caim (ְְּ) significa "lança"; e assim por diante. Por outro lado, os nomes com primeira letra minúscula também podem representar um modo proposital de diminuir ou dessacralizar essas personagens. Por essa razão, os nomes das personagens, incluindo deus, serão grafados com primeira letra minúscula neste trabalho.

\section{Deus e o Demônio: duas faces de um mesmo ser}

O primeiro capítulo do romance narra o contexto do jardim do éden, onde se encontram adão e eva, que, inicialmente, não possuem a língua nem um idioma, mantendo-se, assim, em silêncio. Deus se irrita ao notar seu erro e, como diz o narrador, enfia-lhes "[...] a língua pela garganta abaixo." (SARAMAGO, 2009a, p. 9). Esse é o primeiro sinal de um deus potencialmente colérico, que falha, se arrepende e se enfurece.

Em seguida, surge um tema que tem levantado diversas interpretações ao longo do tempo, que é o pecado original. O texto de Saramago descreve a árvore como símbolo do conhecimento (do bem e do mal). Antes de comer do fruto, adão e eva não tinham acesso a esse conhecimento. Nesse sentido, questiona-se como poderia o casal não almejar o novo, o diferente, já que eles, representantes da humanidade, são seres de desejo, como ressalta Magalhães (2008b, p. 109): “A proibição sobre o fruto é porque o ser humano é um ser de desejos". E o fruto (que representa o conhecimento) é o objeto desejado. Se não fosse assim, não haveria razões para a proibição, uma vez que, como corrobora Rubem Alves (2005, p. 89, itálico do autor), "Não é necessário proibir que as pessoas comam pedras, porque ninguém o deseja. Só se proíbe o desejado."

No romance Caim, o narrador também propõe essa reflexão, uma vez que, sendo seres de desejo, deus não poderia esperar que adão e eva lhe obedecessem. Nessa mesma perspectiva, Magalhães (2008b, p. 109) declara que "O desejo do conhecimento é um desejo fundamental do ser humano, está em seus códigos mais profundos, não pode ser negado por nenhuma repressão." Nesse caso, deus surge como este repressor que proporciona um "mal" para o casal, primeiro por reprimi-los e, depois, expulsando-os do paraíso. 
Nessa ótica, os questionamentos sobre as ações de deus persistem no romance. Se o real objetivo divino fosse que adão e eva não comessem do fruto, diz o narrador, "[...] bastaria não ter plantado a árvore, ou ir pô-la noutro sítio, ou rodeá-la por uma cerca de arame farpado." (SARAMAGO, 2009a, p. 13). Em outras palavras, deus poderia ter evitado o tal pecado, se de fato fosse de sua vontade. Para realizar tais questionamentos, o autor se utiliza da ironia, ao introduzir elementos como a "cerca de arame farpado" no contexto do mito da criação.

Com a fertilidade de eva e subsequente nascimento dos irmãos, surge o protagonista da obra: caim. Em princípio, a relação entre os irmãos caim e abel era de compaixão e amizade recíprocas, como descreve o narrador: "Desde a mais tenra infância caim e abel haviam sido os melhores amigos, a um ponto tal que nem irmãos pareciam, aonde ia um, o outro ia também, e tudo faziam de comum acordo." (SARAMAGO, 2009a, p. 32).

Repentinamente, e sem motivo aparente, deus passa a acolher as oferendas de abel, a queima de cordeiros, e rejeitar as de seu irmão caim, a queima de vegetais. Desse modo, "Estava claro, o senhor desdenhava caim.” (SARAMAGO, 2009a, p. 33). O irmão abel, em vez de apoiar e confortar o irmão, pelo contrário, zombava dele:

Foi então que o verdadeiro carácter de abel veio ao de cima. Em lugar de se compadecer do desgosto do irmão e consolá-lo, escarneceu dele, e, como se isso ainda fosse pouco, desatou a enaltecer a sua própria pessoa [...] (SARAMAGO, 2009a, p. 33).

Por isso, com razão, o ódio é despertado em caim. Indaga-se por qual motivo deus havia realizado essa desfeita com ele, incitando o ódio que leva caim a assassinar seu irmão, como corrobora Salma Ferraz (2012).

Deus, ao questionar o crime cometido por caim, afirmando ter sido resultado de mais um de seus testes, tem como resposta: "[...] mas o primeiro culpado és tu, eu daria a vida pela vida dele se tu não tivesses destruído a minha [...]" (SARAMAGO, 2009a, p. 34). Deus explica sua façanha, "Quis pôr-te à prova", à qual caim responde: 
E tu quem és para pores à prova o que tu mesmo criaste, Como tu foste livre para deixar que eu matasse a abel quando estava na tua mão evitá-lo. [...] permitiste que abel morresse, Tu é que o mataste, $[. .$.$] matei abel porque não podia matar-te$ a ti, pela intenção estás morto, [...] (SARAMAGO, 2009a, p. 34)

Nessa cena, o próprio deus assume sua parcela de culpa pela morte de abel e, como acordo, põe a marca que protegerá caim de qualquer infortúnio. A marca, para deus, representa, como ele mesmo afirma, "[...] um acordo de responsabilidade partilhada pela morte de abel [...]" (SARAMAGO, 2009a, p. 35).

O romance aborda ainda o mito de abraão, fundador de três grandes vertentes religiosas da história: judaísmo, islamismo e cristianismo. Nesta cena, o narrador saramaguiano refere-se tanto a deus quanto a abraão como "filho da puta". O primeiro por ter ordenado o assassinato do garoto isaac e o segundo por ter-lhe obedecido:

O lógico, o natural, o simplesmente humano seria que abraão tivesse mandado o senhor à merda, mas não foi assim [...] Fiquem aqui com o burro que eu vou até lá adiante com o menino, para adorarmos o senhor e depois voltamos para junto de vocês. Quer dizer, além de tão filho da puta como o senhor, abraão era um refinado mentiroso, pronto a enganar qualquer um com a sua língua bífida, que, neste caso, segundo o dicionário privado do narrador desta história, significa traiçoeira, pérfida, aleivosa, desleal e outras lindezas semelhantes. (SARAMAGO, 2009a, p. 79)

Nota-se, portanto, que a personagem deus se apresenta como um ser cruel, uma vez que ordena ou permite crimes, bem como testa as outras personagens, além de egoísta, por exigir soberania, obediência de todos, desejando tudo apenas para si. O garoto isaac, por sua vez, questiona a ordem de deus, acusando-o de rancoroso por sempre condenar à ruína aqueles que não lhe correspondem: 
Pai, que mal te fiz eu para teres querido matar-me, a mim que sou o teu único filho, Mal não me fizeste, Isaac, Então por que quiseste cortar-me a garganta como se eu fosse um borrego, perguntou o moço, [...] a ideia foi do senhor, que queria tirar a prova, A prova de quê, Da minha fé, da minha obediência, E que senhor é esse que ordena a um pai que mate o seu próprio filho, [...] E se esse senhor tivesse um filho, também o mandaria matar, perguntou isaac, O futuro o dirá, Então o senhor é capaz de tudo, do bom, do mau e do pior, Assim é, Se tu tivesses desobedecido à ordem, que sucederia, perguntou isaac, $\mathrm{O}$ costume do senhor é mandar a ruína, ou uma doença, a quem lhe falhou, Então o senhor é rancoroso [...] (SARAMAGO, 2009a, p. 82)

Ao indagar se deus mataria seu próprio filho, o texto faz alusão a Jesus, que seria enviado à morte. Em outras palavras, deus está sempre ligado ao sacrificio. Agradar-lhe significa sacrificar-se ou sacrificar algo ou alguém, senão, haverá a punição.

No monte sinai, quando moisés encontra-se com deus e, enquanto isso, a multidão adora um bezerro de ouro, caim verifica a maldade de deus:

Não bastavam sodoma e gomorra arrasadas pelo fogo, aqui, no sopé do monte sinai, ficara patente a prova irrefutável da profunda maldade do senhor, três mil homens mortos só porque ele tinha ficado irritado com a invenção de um suposto rival em figura de bezerro, Eu não fiz mais que matar um irmão e o senhor castigou-me, quero ver agora quem vai castigar o senhor por estas mortes, pensou caim, e logo continuou, Lúcifer sabia bem o que fazia quando se rebelou contra deus [...] (SARAMAGO, 2009a, p. 101, negrito nosso)

Nesse trecho, nota-se que Caim dá razão a Lúcifer por ter ficado contra deus, pois sua crueldade supera a do Demônio. Deus julga todos, mas ninguém pode julgá-lo, pois ele decide todas as coisas e pode cometer qualquer injustiça. 
Nas cidades de sodoma e gomorra, milhares de pessoas, incluindo crianças, são mortas pelo fogo de deus, que as julga estarem cometendo pecados exorbitantes, inclusive práticas homossexuais (deus também é homofóbico). Os dez filhos da personagem job são mortos e sobre esse fato realizou-se uma espécie de assembleia no céu, quando ocorre o seguinte:

[...] realizou-se no céu uma nova assembleia dos seres celeste e satã estava outra vez entre eles [...] A mulher de job, de quem até agora não tínhamos ouvido uma palavra, nem sequer para chorar a morte dos seus dez filhos, achou que já era hora de desabafar e perguntou ao marido, Ainda continuas firme na tua rectidão, eu, se fosse a ti, se estivesse no teu lugar, amaldiçoaria a deus ainda que daí me viesse a morte, ao que job respondeu, Estás a falar como uma ignorante, se recebemos o bem da mão de deus, por que não receberíamos também o mal, esta foi a pergunta, mas a mulher respondeu irada, Para o mal estava aí satã [...] Sempre ouvi dizer aos antigos que as manhas do diabo não prevalecem contra a vontade de deus, mas agora duvido de que as coisas sejam assim tão simples, o mais certo é que satã não seja mais que um instrumento do senhor, o encarregado de levar a cabo os trabalhos sujos que deus não pode assinar com seu nome. (SARAMAGO, 2009a, p. 140)

Nesse trecho, a mulher de job classifica deus como covarde, na medida em que, por não ter coragem de assumir suas ações, responsabiliza satã por elas. Desse modo, a injustiça divina revela-se em várias cenas como: adão e eva foram expulsos do paraíso só porque desobedeceram a deus ao comerem do fruto, caim foi punido porque matou o irmão abel (fato incitado pelo próprio deus), abraão seria punido se não obedecesse a deus em assassinar seu filho isaac, os habitantes de sodoma e gomorra foram queimados por cometerem pecados (segundo deus) inadmissíveis, vários indivíduos foram mortos no monte sinai simplesmente por adorarem um bezerro de ouro. 
Embora multifacetado, o romance parece ter como principal foco questionar as ações de deus, que de forma impiedosa e cruel devasta milhares de indivíduos simplesmente por não atenderem às suas expectativas, sendo, portanto, um deus "mal".

No desfecho do romance, deus dirige-se a caim e declara: "Caim és, e malvado, infame matador do teu próprio irmão [...]" (SARAMAGO, 2009a, p. 172). A que caim replica: "Não tão malvado e infame como tu, lembra-te das crianças de Sodoma.” (SARAMAGO, 2009a, p. 172). Esse trecho, de certo modo, resume a principal tese apresentada aqui, que é a manifestação do lado mal de deus, ou deus e o Demônio como duas faces de um mesmo ser.

A personagem deus é o princípio e o fim, alfa e ômega. Com isso, o criador é responsável pela sua criação, incluindo o "mal" e o demoníaco. Essa concepção surge do princípio monoteísta que a tradição judaicocristã tem professado. É importante destacar que o deus e o Demônio sobre os quais se fala aqui, bem como todas as outras personagens, estão em nível literário, ou seja, trata-se de ficção, porém, uma ficção que tanto levanta novas perspectivas em relação aos textos bíblicos originais quanto aponta questionamentos sobre as interpretações que têm sido preservadas por eclesiásticos ao longo da história. Portanto, o romance Caim, de José Saramago, levanta debates acerca de mitos e tradições cuja legitimidade nunca é questionada, por ser tida como sagrada. 


\section{Bibliografia}

ALVES, Rubem. O que é religião? 6. ed. São Paulo: Loyola, 2005.

BRANDÃO, Eli. Resignação de Jó em "Ritual de Danação”, de Gilvan Lemos. In: FERRAZ, Salma et al. Deuses em poéticas: estudos de literatura e teologia. Belém: UEPA, UEPB, 2008.

FERRAZ, Salma. As Faces de Deus na Obra de um Ateu. 2. ed. Blumenau: EDIFURB, 2012.

MAGALHÃES, Antonio Carlos de Melo. A Bíblia como obra literária: hermenêutica literária dos textos bíblicos em diálogo com a teologia. In: FERRAZ, Salma et al. Deuses em poéticas: estudos de literatura e teologia. Belém: UEPA, UEPB, 2008a.

.; PORTELA, Rodrigo. Expressões do sagrado: reflexões sobre o fenômeno religioso. São Paulo: Santuário, 2008 b.

SARAMAGO, José. Caim. São Paulo: Companhia das Letras, 2009a.

Igreja católica critica novo livro de José Saramago. 2009b.

Disponível em: <http://www.josuegoncalves.com.br/familiaeGraca/artigos_ detalhe.asp? $\operatorname{cod}=1226 \&$ sessao $=10>$ Acesso em: 29 de ago 2010 .

\section{Imagem}

Disponível em http://4.bp.blogspot.com/_EmX17974UbE/

TRd3ZWTUBCI/AAAAAAAAEsY/KiEpXOzUfOE/s1600/caim-abel.jpg. Consultado em 07/10/2012 



\section{Vivendo na morte: a História dos Vampiros e seu lugar na cultura popular}

Iliane Tecchio ${ }^{2}$

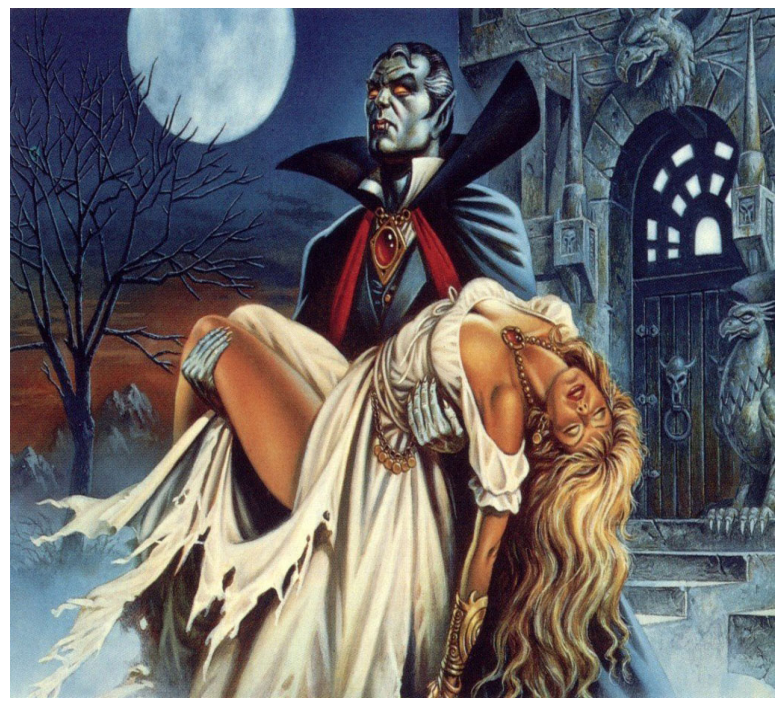

O vampiro é um ser lendário que tem sido temido por pessoas ao redor do mundo por muitos e muitos séculos. Apesar da grande diferença geográfica e temporal de onde surgiram as histórias sobre vampiros, o folclore que o abarca é surpreendentemente uniforme especialmente em relação aos poderes e as suas limitações do vampiro. De acordo com Melton (2003, p. XXXVII) em cada cultura o vampiro adquiriu características distintas que precisam ser levadas em consideração de acordo com seu contexto ambiental. A maioria das descrições sobre ataques

2 Doutoranda em Estudos da Tradução - UFSC- SC, professora de Língua Inglesa na rede Municipal de Educação do município de São José - SC. Email: iliane.tecchio@gmail.com 
destes temidos seres tem origem, principalmente, na Grécia, na China, na Índia, no Leste Europeu e "civilizações como a dos sumerianos, dos babilônios, dos indianos e os povos hebreus, maias e astecas conviveram como o fenômeno do Vampirismo." (TORRIGO, 2009, p. 10).

O vampiro é normalmente considerado como sendo aquele que existe no estado de "morto vivo", literalmente um corpo reanimado. Algumas tradições descrevem o vampiro como sendo um corpo habitado por um ser maligno, outros, como um corpo possuído por uma feitiçaria [uma situação dentro dos domínios da magia negra] e ainda outros que descrevem o vampiro como um corpo possuído pela alma que ele tinha em vida. Para Bourre (1986, p. 04) a Europa Central foi, durante muito tempo, o feudo "destes senhores da noite", e que as antigas religiões caracterizavam como diabos ou demônios. "Para um vasto público," afirma Lecouteux (2005, p. 10) “o vampiro é um sugador de sangue que se aproxima à noite de quem está dormindo e provoca-lhes morte lenta aspirando sua substância vital".

Qualquer que seja sua origem, o vampiro é um ser que tinha vida, morreu fisicamente e então se ergueu do caixão para andar na terra e assustar os vivos. De acordo com McNally e Florescu (1995, p.124) a ideia do vampiro supõe o conceito oriental do eterno retorno, segundo o qual ninguém é realmente destruído, mas volta infinitas vezes em reencarnações. Eles são seres noturnos, e o brilho do sol transforma-os em pedra e algumas vezes em pó. Tipicamente, eles são descritos como vestindo capas pretas, são magros e pálidos e como tendo habilidade de voar e transformar-se em animais, sendo o morcego o mais famoso, embora se essas características estavam ou não presentes nos mitos originais sobre vampiros, não se sabe ao certo. Eles habitam o caixão durante o dia e perambulam à noite, não suportam igrejas e temem o alho. O propósito de suas andanças é buscar aquilo que mantém seu estado de morto-vivo: sangue. Esse é o alimento do vampiro, o fluido essencial e único para a sua "vida," e que nutre sua imortalidade. Suas vítimas ficam anêmicas e extremamente fracas até que comumente morrem, enquanto que ele, o vampiro, continua no estado de Nosferatu. O vampiro retira as qualidades de vida e saúde do sangue dos humanos ou animais tornando-se, assim, extremamente forte. 
É somente durante o dia que aqueles que procuram destruir este ser das sombras podem fazer suas tentativas, pois o poder do vampiro existe somente durante a noite, desaparecendo ao amanhecer já nas primeiras cantigas dos galos. Quando o corpo de um vampiro é exumado, sua aparência é de um corpo ainda em vida, apenas com algumas mudanças resultantes do tempo passado desde o seu enterro. O corpo parece ter engordado e inchado, os cabelos e as unhas crescidas, os lábios com manchas de sangue, olhos abertos, e as bochechas parecem até mais rosadas quando em vida. Para acabar com este morto vivo uma estaca deve ser cravada em seu coração. Então, a cabeça deve ser cortada e colocada entre as pernas. Uma vez que o vampiro é "morto", o corpo se transforma em pó imediatamente, ou no estado de decomposição que deveria estar naturalmente por ocasião do período subsequente a sua primeira morte. Frequentemente o corpo é também cremado para não deixar dúvidas da sua destruição total.

Somente um vampiro pode criar outro vampiro, então a lógica nos leva a crer que a história dos vampiros começou com um simples vampiro que criou outros vampiros. Como o fato de quem nasceu primeiro: o ovo ou a galinha, resta saber como nasceu o primeiro vampiro, pois, se não existiu nenhum vampiro para fazer o primeiro vampiro, como o primeiro vampiro nasceu? Dunn-Mascetti na introdução da obra Vampiros: além da saga Crepúsculo (2010, negrito nosso) relata que:

As origens dessas criaturas poderiam remontar ao antigo Egito, quando o culto e a veneração aos mortos eram representados de forma ritual em cerimônias nas quais os acólitos adoravam uma divindade semelhante a um pássaro preto. Esse pássaro sinistro representava o vôo da alma no momento da morte e sua viagem ao mundo das sombras. Os mortos que estavam "vivos" no mundo a que pertenciam, ocasionalmente voltavam e às vezes levavam os habitantes do mundo da luz para o desconhecido, roubando-lhes a vida.

Enquanto Vlad Tepes, um príncipe do século XV conhecido como O Empalador, parece ter inspirado o vampiro ficcional moderno, as raízes do vampiro "real" têm origens muito diferentes. Como uma entidade cultural, ele é um fenômeno mundial. Praticamente cada cultura 
tem sua história sobre vampiros. Os relatos seguem um padrão consistente: alguma desgraça inexplicável se abateria sobre uma pessoa, uma família ou uma cidade, talvez uma seca destruísse toda a plantação ou surgisse uma epidemia. Antes que a ciência fosse capaz de explicar os fenômenos meteorológicos e o surgimento de doenças e epidemias, os acontecimentos que não tinham uma explicação ou causas óbvias poderiam ser culpa do vampiro. Ele era uma resposta fácil para a velha questão do porque que coisas ruins acontecem às pessoas.

Duas doenças não explicadas pela ciência na época do surgimento do vampirismo podem contribuir para nos ajudar a entender a origem desta crença.

Uma teoria envolve uma doença rara conhecida por Porfiria. Basicamente, porfiria faz parte de um grupo de distúrbios raros transmitidos hereditariamente, conhecidos como "porfirinas" em que uma importante parte da hemoglobina, a heme, não é produzida corretamente podendo causar: palidez extrema, lábios muito vermelhos, pele sensível ao sol, aumento da produção de pêlos, saliva e urina vermelhas, dentes deformados, mau hálito, lábios contraídos com lábios caninos expostos, crises oriundas da ingestão de alho, bebidas alcoólicas, etc. ${ }^{3}$

A catalepsia pode ser uma outra doença que o vampirismo tenha se inspirado. A catalepsia é associada com a epilepsia e a esquizofrenia, distúrbios que afetam o sistema nervoso central. Uma pessoa que sofre de um ataque cataléptico pode ter ser corpo paralisado, a frequência cardíaca e a respiração praticamente inexistem. É possível que uma pessoa que esteja em uma situação de catalepsia seja dada como morta, especialmente porque o episódio da doença pode durar horas ou até mesmo dias ${ }^{4}$. Assim, no passado, as pessoas com essa doença poderiam ter sido confundidas como cadáveres e serem enterradas ainda com vida. Após, eles poderiam emigrar do estado da doença e então sair dos túmulos. Esse comportamento, sem explicação científica na época, foi associado com vampirismo.

Temos também algumas crenças que explicam as causas de alguém se transformar em vampiro após a morte. Entre as diversas crenças existentes, lembramos algumas. A principal causa se refere a alguma irregularidade

3 Fonte: http://educar.sc.usp.br/licenciatura/98/vampiros.html

4 Fonte: http://super.abril.com.br/superarquivo/2002/conteudo_120294.shtml 
que acontece nos rituais do enterro. Assim, a alma não recebe a permissão de descansar e é obrigada a caminhar no mundo dos vivos até que seu corpo tenha um enterro apropriado ou dentro das leis da igreja por terem sido excomungados ou que tenham morrido sem serem absolvidos de seus pecados em vida, e ainda, os que tenham cometido suicídio ou morrido por afogamento. Para aqueles que tiveram mortes violentas é negado um enterro apropriado, bem como, a aqueles que morreram por ação de um raio porque suas mortes são atribuídas diretamente à ira de Deus. Aqueles que foram perversos em vida eram enterrados em solos não consagrados por serem suspeitos de feitiçaria. Os que morreram sob a maldição de uma bruxa, as crianças recém-nascidas filhos ilegítimos de segunda geração, as crianças não batizadas, o sétimo filho de uma família, qualquer um que tenha sido tocado pelo sangue de um vampiro, ou qualquer um que é morto por um vampiro vai se tornar um vampiro após seu enterro.

Existem também dois mitos parecidos que explicam a origem do vampiro. Eles provavelmente são variações de contos do mesmo folclore. O primeiro mito é a história de Lamia, uma linda rainha que era amada por Zeus. Segundo Suenaga (2010) as lâmias (do grego laimos: garganta) da Grécia antiga, eram espécies de monstros ou demônios que apareciam sob a forma feminina com cabeça de mulher, corpo de dragão e voz de serpente, devoravam cadáveres em cemitérios e sugavam o sangue de criancinhas. Uma criança nasceu da união de Lamia e Zeus. Hera, sob o domínio da inveja e da ira, raptou a criança. Triste, Lamia foi viver nas profundezas do mar. O tempo passou, e Lamia, agora representada por uma forma raivosa, perambulou pelas noites, roubando e comendo os bebês recém-nascidos. Gradualmente ela passou a seduzir homens jovens, e enquanto mantinha relação sexual com eles, sugava o sangue deles até a morte. Lamia era capaz de mudar de uma forma bela até uma assustadora. A metade dragão era considerada um dos estágios de sua existência e/ou a transição entre uma linda mulher e uma serpentedragão. As vampiras femininas da modernidade são descritas como tendo o cabelo ruivo, pele pálida, olhos verdes.

O segundo mito envolve Lilith, provavelmente a primeira mulher de Adão. Lilith foi criada ao mesmo tempo em que Adão. Aguiar (2009, p. 63) nos diz que o legendário em torno da Bíblia fixou que Lilith seria uma primeira mulher de Adão, supostamente a mãe dos demônios ou 
dos falsos espíritos, uma espécie de Vampira, devoradora de crianças e adolescentes, chupadora de sangue e uma das mulheres mais marcantes da literatura. Ela recusou a ser submissa a Adão, criando assas e fugindo dele. Os anjos encontraram o esconderijo de Lilith e falaram que a punição dela por ter deixado Adão seria que todas as crianças que nascessem dela morreriam. Com tristeza profunda, ela pensou em suicídio. Os anjos, com pena, deram a ela completo poder sobre os bebês na primeira semana de vida. Mais tarde Lilith se tornou esposa de Satanás, ele mesmo descrito como uma serpente. Lilith também seduzia homens jovens e depois os matava.

Um importante fator que também contribuiu para a construção da figura do vampiro se refere ao grande medo primitivo da morte e tudo o que era conectado a ela. As crenças sobre o estado da morte variavam muito, e também aquelas relacionadas com a exata extensão da ligação entre a vida e a morte ${ }^{5}$. Os primitivos Europeus acreditavam que o corpo de um morto tinha que ser enterrado. Para que a alma passasse para qualquer tipo de mundo astral depois da morte, o enterro era uma necessidade. O corpo carregava o espírito da terra, então o espírito não seria libertado até que o corpo não fosse coberto por terra até sua total desintegração. Uma crença universal Eslávica acreditava que após a morte a alma pairava sobre a terra, flutuando perto do túmulo e visitando os lugares conhecidos em vida. Após quarenta dias a alma tentava reentrar no corpo enterrado e parcialmente decomposto pelo tempo. A alma é repelida pela decomposição, e deixa a terra para voltar para seu novo ambiente astral. Então o dever do homem era enterrar os corpos mortos para o descanso da alma e para salvar suas próprias vidas, pois caso contrário, as almas dos corpos que não foram enterrados assombrariam os vivos.

Os povos primitivos não viam a morte como a completa extinção da vida, ou a separação total dela. Eles acreditavam que o morto vivia em um mundo subterrâneo. No início pensava-se que esse mundo subterrâneo era a réplica exata do mundo dos vivos, crença reforçada pelo fato de que o sol parecia penetrar na terra quando anoitecia. Posteriormente, surgiu a concepção de que o mundo subterrâneo era escuro e horrível. Parecia ser a extensão do mundo subterrâneo que Ishtar [um dos deuses

5 Para aprofundamento do assunto recomendo a leitura da revista História Viva, Entre o

Céu e o Inferno, edição especial temática no. 25, 2009. 
da religião mesopotâmica: deusa da chuva, da primavera e da fertilidade] entrou na procura de seu amor, Tammuz. Como esse é um mito antigo, as ideias dos Gregos e dos Romanos sobre o inferno podem ter sido desenvolvidas da ideia que a Mesopotâmia tinha sobre o inferno. Para os antigos romanos, a alma descansa com o corpo dentro do túmulo. De acordo com Lecouteux (2005, p. 59) objetos relativos à manutenção da vida eram colocados em volta do túmulo para sustentar a alma em sua vida após a morte. A existência da alma depois da morte era muito enfatizada. Os Gregos também acreditavam na imortalidade da alma. Para eles, a alma residia com o corpo no túmulo.

Outro fator que se tornou parte do surgimento do vampiro diz respeito ao significado especial do sangue para a vida. As andanças noturnas dos vampiros eram especialmente para a procura de sangue. A obtenção dessa meta significava a renovação das capacidades corporais da vida humana, mas não somente temporariamente. Se alimentando do sangue dos vivos, o vampiro adquiria poder da palavra, força, resistência, potência sexual, e aparência de um corpo extremamente saudável. A vida do vampiro, de fato, vinha do sangue de suas vítimas, literalmente e figurativamente. A ideia de beber sangue para ser imortal não é estranha à mente humana. Indianos, gregos e cristãos fazem parte dessa concepção. O homem primitivo sentia que o sangue era a vida da pessoa. A prova empírica era o fato de que a perda de sangue em grande quantidade era sempre seguida de morte. Assim, a possessão do sangue era a essência da vida. Fisicamente levando sangue de uma pessoa para outra resultava na melhoria da vitalidade da sua própria vida. Desde que o sangue era tão precioso para a vida, se pensava que ele tinha uma alma própria, assim, beber do sangue de outra pessoa era identificado como a remoção e a possessão da alma e, ainda, a concepção de que por o corpo de alguém no seu próprio corpo significava obter mais vida.

Como exemplo podemos citar a Condessa húngara Elizabeth Bathory [1560-1614], conhecida também como A Condessa de Sangue, era acreditada como sendo uma vampira. Ela acreditava que banhar-se em sangue e/ou talvez beber sangue, era o segredo de manter-se jovem e bela para sempre. Por causa dessa crença, ela torturou e matou centenas de jovens, a maioria mulheres jovens. Ela foi condenada por seus crimes, sendo presa em um pequeno cômodo em um castelo onde morreu. Até onde vai a lenda e onde terminal o real nunca saberemos... 
A origem dos mitos eslavos sobre vampiros desenvolveram-se durante o século IX advindo de conflitos entre os pagãos e os cristãos. Os cristãos venceram os conflitos, mas algumas crenças pagãs, como a do vampiro, sobreviveram no folclore. A Romênia encontra-se geograficamente cercada por países Eslavos, então não é de admirar que seus vampiros sejam variantes dos vampiros Eslavos. Eles são chamados Strigoi, palavra baseada no termo Romano Strix aquele que pia como uma coruja, mas que após foi expandida para a significação de demônio ou bruxa e ainda ao espírito maligno que atacava as crianças durante a noite. Os romenos também usavam o termo vircolac - variação do grego vrykolakas - para descrever uma velha criatura mitológica parecida com um lobo que devorava o sol e a lua.

O termo vircolac descrevia uma pessoa que periodicamente se transformava em diversos animais, geralmente num porco, cachorro ou lobo. Nosferatu é um termo arcaico do antigo eslavo derivado aparentemente de nosofuratu, do grego nosophoros, "portador de pragas". Tem sido usado como uma palavra romena significando "Morto-vivo" ou "Demônio". A palavra se popularizou com a contribuição de Friedrich Wilhelm Murnau no filme Nosferatu (1938) baseado na obra Drácula (1897) de Bram Stoker 6 .

Na Romênia, acreditava-se, o vampiro aparecia primeiro e principalmente como um produto de nascimento irregular. As crianças nascidas fora do casamento ou que morressem antes de serem batizadas poderiam se tornar vampiros. Mulheres grávidas que não comessem sal ou que se permitissem ser vistas por um vampiro poderiam gerar uma criança vampira. O sétimo filho do mesmo sexo numa família tenderia a nascer com um rabo e se tornar um vampiro. Embora as crianças frutos de nascimentos irregulares fossem as principais candidatas ao vampirismo, qualquer pessoa poderia se tornar um vampiro se mordida por um deles. Outros vampiros em potencial incluíam pessoas que levavam uma vida pregressa (incluindo as que juravam em falso), bruxas (que tivessem tido relações com o Demônio), um cadáver sobre o qual um gato tivesse pulado ou uma pessoa que cometesse suicídio.

6 Fonte: http://www.consuladoromenia.com.br/turismo.php 
De acordo com Torrigo (2009, p. 16) os vampiros tem um lugar de destaque na religiosidade cigana. Segundo o pesquisador, entre os ciganos havia a profissão de "caçador de Vampiros" (Dhampir) sendo o caçador ele próprio filho de um Vampiro e "que morava entre os ciganos e os eslavos do sul” (MELTON, 2003, P. 87). O Mulo (aquele que está morto) era a forma mais conhecida de Vampiro cigano. Um morto-vivo que atacava durante a noite e voltava para a sepultura ao amanhecer. Este vampiro foi acreditado por voltar do túmulo e fazer coisas maldosas e também chupar o sangue de uma pessoa, geralmente um parente que tinha contribuído para com sua morte ou que não tivesse observado as cerimônias de enterro e até quem tivesse guardado as posses materiais do morto ao invés de destruí-las como era costume. Mesmo hoje em dia os Ciganos são frequentemente lembrados em filmes e na literatura de ficção sobre vampiros, sem dúvida, tendo a influência da obra Drácula de Bram Stoker na qual os ciganos aparecem carregando caixões do vampiro com terra nativa e ainda protegendo-o.

O tipo mais moderno dessa criatura apareceu por volta do século XII na Europa Oriental, mas o frenesi apareceu em algum momento do século XVIII. Nesta época houve um grande surto de vampiros na Europa Oriental que chamou a atenção do público. O que seu viu foi uma grande busca e caça para a exterminação dos vampiros pela população e até por funcionários do governo. Os corpos das pessoas que eram suspeitas de serem vampiros eram desenterrados e decapitados ou uma estaca era fincada no coração. Também era costume enterrar a pessoa de cabeça para baixo para que, ao tentar escapar, cada vez mais ela mergulhasse para as profundezas do solo.

Estudiosos começaram a analisar seriamente a existência dos vampiros pela primeira vez devido ao que foi considerado um surto de ataques de vampiros na Prússia Oriental em 1721 e no império HúngaroAustríaco de 1725 a 1734. Dois casos famosos chamaram a atenção: Peter Plogojowitz e Arnold Paole. 


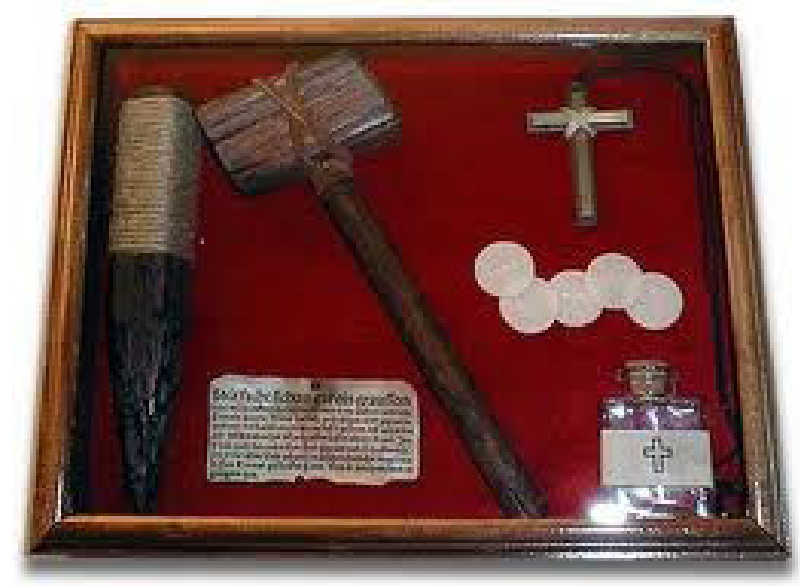

Conta a história que Peter Plogojowitz morreu aos 62 anos, mas retornou algumas vezes após a morte para pedir comida a seu filho. Quando o filho recusou, foi encontrado morto no dia seguinte. Logo Peter Plogojowitz retornou novamente e atacou a vizinhança que morreu através da perda de sangue. Arnold Paole, um ex-soldado da Sérvia que se tornou fazendeiro e foi atacado por um vampiro anos antes de morrer. Após a sua morte, pessoas começaram a morrer inexplicavelmente e então se acreditava que Paole tinha retornado para caçar os seus vizinhos. Segundo Dunn-Mascetti (2010, p. 22) o caso de Paul foi tão grave que atraiu a atenção das autoridades e estas solicitaram um relato da história que acabou sendo conhecida como Visium Et Repertum (Visto e Descoberto) e que de acordo com Bourre (1986, p. 6), o inquérito foi conduzido pelo tenente Buttner, do regimento de Alexandre de Vurtemberga, a 7 de Janeiro de 1732, que intrigou Luís XV e o Duque de Richelieu.

Estes dois casos foram documentados em detalhes. Oficiais do Governo examinaram os casos e os corpos, escreveram relatórios, e mais tarde livros foram escritos e distribuídos pela Europa após o caso de Paole. De acordo com Melton (2003, p. X) provavelmente a palavra vampire ou vampyre entrou pela primeira vez na língua inglesa quando a história foi publicada por dois periódicos ingleses, o London Journal e o Gentleman's Magazine em 1732. A história estimulou debates nos círculos intelectuais principalmente na tentativa de descobrir maneiras racionais de explicar o fenômeno desses relatos sobre vampiros. As controvérsias 
sobre se os casos realmente aconteceram ou não perduraram por muitas gerações. O problema foi evidenciado pela população rural que dizia estar sendo alvo de ataques de vampiros. Muitos estudiosos falaram que vampiros não existiam e atribuíram os casos a enterros prematuros, ou a raiva cujo um dos sintomas é uma sede excessiva.

O vampirismo, como descrito acima, tem, provavelmente, sua origem como sendo um produto dos medos, dos desejos, dos anseios e das crenças dos homens. O medo primitivo da morte, a busca por imortalidade, o desejo de controlar o meio ambiente, conceitos antropomórficos sobre a fertilidade da terra e a sua criação, seu animismo, sua concepção de universo e seu lugar nele, a gradual maturidade intelectual, convergiram para desenhar a imagem do vampiro que temos hoje. E como nos diz Lecouteux:

A espantosa unanimidade das reflexões, para além de todas as variantes, prova que o problema da vida e da morte é realmente fundamental, o que não é nada espantoso já que, em função das respostas apresentadas, o homem pode conhecer o desespero ou a esperança, encontrar um sentido para a sua existência ou conhecer o absurdo. (LECOUTEUX, 2005, p. 39).

O vampiro existe ou não? Ele certamente não pode ser estudado apenas como um fenômeno mitológico. Há explicações científicas, sociais e psicológicas ao invés de apenas concepções mitológicas. O folclore sobre os "hábitos" macabros dos vampiros pode ter advindo de fenômenos psicológicos ligados a ações de pessoas vivas em relação aos mortos. As perversões incluem: necrofilia, comer o morto, necrosadismo, sentir satisfação erótica através da mutilação de um cadáver e ainda o desejo não natural por sangue. Devido ao pouco desenvolvimento da ciência médica na época em que os vampiros eram temidos, as pessoas em coma ou em estado de choque eram na maioria das vezes, enterrados vivos, e aqueles que conseguiam escapar das sepulturas eram temidos por eles terem "retornados".

O desenvolvimento das concepções do homem sobre a criação ao longo das épocas tem cristalizado a forma como o vampiro pode ser descrito pela frase revolucionária: "Ontogenia recapitula filogenia" - o 
desenvolvimento individual da pessoa repete a história da raça. O desenvolvimento perceptivo de uma criança da infância até a idade adulta segue a mesma progressão que as concepções do homem sobre o seu ambiente, das raízes mais primitivas até a sua presente sofisticação. O homem primitivo via o seu mundo como um bebê vê o seu: um ambiente que ele não pode controlar: as estações, o dia e a noite, e a progressão da vida para a morte. Como uma criança faz, ele nomeou as coisas, pois dar nomes significa ter o controle e o poder. Ele atribuiu vida a objetos inanimados e tentou sobreviver nesse seu desconhecido universo.

Maravilhas diárias, como o nascer do sol a cada manhã, deram confiança ao homem do seu ambiente. Como uma criança que sente medo quando algo estranho acontece, também o homem sentia medo quando acontecia alguma mudança no ambiente em que vivia. Embora o homem tenha desenvolvido intelectualmente, ele sempre foi objeto de fantasias sombrias que, apesar do avanço tecnológico, nunca puderam ser explicadas. $\mathrm{O}$ vampiro nasceu dessas fantasias e ainda permanece na raça humana, como um medo infantil inexplicável pode permanecer em um homem para o resto de sua vida. E embora os vampiros "originais" há tempos já não existem, seu legado continua e eles continuam fascinando o mundo. Parece que nem a ciência e nem tampouco estacas de madeira conseguirão "matar" o vampiro para sempre.

A literatura, o cinema, o teatro e as artes em geral nos dão uma visão da sede do público por vampiros que parece ser infinita, assim como a sede dos vampiros por sangue. Escritores modernos de ficção, incluindo Stephanie Meyer, Anne Rice, Stephen King, André Vianco, e inúmeros outros, têm um folclore riquíssimo em que se basear.

\section{Bibliografia}

AGUIAR, Flávio. Sob o olhar da crítica literária. A Bíblia muito além da Fé. Entre Livros, ano I, n. 2, edição especial, p. 60-67, 2009.

ARGEL, Martha. NETO, Humberto Moura. (Org.). O vampiro antes de Drácula. São Paulo: Aleph, 2008.

BOURRE, Jean-Paul. Os Vampiros. Portugal: Euro - América, 1986. 
DUNN-MASCETTI, Manuela. Vampiros: além da saga Crepúsculo.

Tradução de Denise de C. Rocha Delela. São Paulo: Pensamento, 2010.

JÚNIOR, Pedro Augusto Moraes Simões. O Eterno Retorno de

Nosferatu. 2009. Disponível em http://migre.me/7tzgG. Acesso em setembro de 2010

LECOUTEUX, Claude. História dos Vampiros: autópsia de um mito. UNESP, 2005.

MCNALLY T, Raymond. FLORESCU, Radu. Em busca de Drácula e outros Vampiros. Tradução: Luiz Carlos Lisboa. São Paulo: Mercuryo, 1995.

MELTON, J. Gordon. O Livro dos Vampiros. São Paulo: M. Books do Brasil Editora LTDA, 2003.

MORAES, A.C. Marco. O Vampiro: Um retrato em mosaico. In:

FERREIRA, Cid Vale (org.). Voivode: Estudos Sobre os Vampiros. Jundiaí, São Paulo: Pandemonium, 2002.

STOKER, Bram. Drácula. Tradução de Theobaldo de Souza. Porto Alegre: LPM, 2007.

SUENAGA, Claudio Tsuyoshi. Vampiros: do gótico ao ufológico. Revista Sexto Sentido, São Paulo, n. 50, jun. 2010.

TORRIGO, Marcos. Vampiros: origens, lendas e mistérios. São Paulo: Idéia e Ação, 2009.

\section{Imagem:}

1) Disponível em http://3.bp.blogspot.com/-RLtXYVtKnTM/

Te5c2Zrf6CI/AAAAAAAAAEc/CEuvjPWR_DE/s1600/vampiro1.jpg. Consultado em 07/10/2012.

Disponível em http://3.bp.blogspot.com/_iBYMT_507zs/SQmxPcQS2-I/ AAAAAAAAfro/tTtIVvLOEL0/s400/Vampiro-1.jpg. Consultado em 07/10/2012. 



\section{O Horror na Literatura Gótica e Fantástica: uma breve excursão de sua gênese à sua contemporaneidade}

Rhuan Felipe Scomaçao da Silva (PG-FAFIPAR $)^{1}$

A emoção mais antiga e mais forte da humanidade é o medo, e o mais antigo e mais forte tipo de medo é o medo do desconhecido. Esses fatos poucos psicólogos irão discordar, e sua verdade admitida deve estabelecer, por todo o tempo, a genuidade e dignidade do estranhamente horrivel conto como uma forma literária. (LOVECRAFT, 1973 p. 12)²

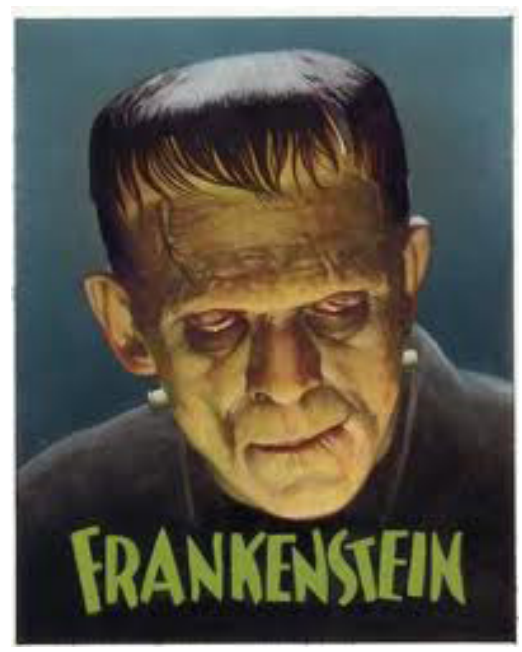

1 Graduado em Letras - Português, Inglês e Respectivas Literaturas pela UNESPAR Campus FAFIPAR, Pós graduando em Metodologia de Ensino na Educação Superior pela FACINTER e Pós graduando em Ensinos Linguísticos e Literários pela UNESPAR Campus FAFIPAR. Email: rfss_hcp@hotmail.com / rs.ss2010@uol.com.br

2 Tradução livre do autor 
Lovecraft relata, no parágrafo acima, o que é literatura de horror em sua concepção, e, considerando o autor como um dos maiores nomes do gênero, há de se considerar a verossimilhança de tal afirmação. Porém, para consagrar um valor ainda mais verossímil à afirmativa de Lovecraft, analisemos o que alguns teóricos e escritores dizem acerca desse gênero da literatura fantástica. França escreve logo no início de seu artigo que: "Literatura de Horror é a denominação mais usual dada a textos ficcionais que, de algum modo, são relacionados ao sentimento de medo físico ou psicológico (França, 2008)". Adicionemos, também, a visão de Beghini com relação ao gênero:

O terror é um gênero literário riquíssimo, pois mostra ao leitor o que não é convencional em narrativas, mas que está presente em cada um de nós. Todo ser humano, desde a infầncia, tem vários medos e os alimenta a cada dia, seja por desconhecer algo e persistir na ignorância, seja por vivenciar experiências traumáticas, seja através do medo alheio, que é divulgado e se torna de senso-comum. O medo, a principal sensação que se tem ao ler um livro de Edgar Allan Poe, de Stephen King ou de H. P. Lovecraft, por exemplo, é uma descarga enorme que causa considerável impacto físico-emocional no indivíduo. Portanto, as mensagens que o texto de terror nos transmite, sejam elas explícitas ou implícitas, serão gravadas irremediavelmente na memória, fazendo-nos muitas vezes até sonhar com tais situações macabras. (BEGHINI, 2010)

Tzvetan Todorov apresenta a visão de diversos outros escritores para uma tentativa de representação do gênero, afirmando que a relação de gênero é muito particular, e que "há um fenômeno estranho que pode ser explicado de duas maneiras, por tipos de causas naturais e sobrenaturais. A possibilidade de vacilar entre ambas cria o efeito fantástico" (TODOROV, 1981 p. 16). Dessa forma, defende que o fantástico, o sobrenatural, só existem por causa da dúvida.

Logo, a literatura de horror em si se ramifica em vários outros gêneros, e nessa grande gama serão encontrados todos os diferentes graus do horror: psicológico, social, alegórico, gótico, ficção científica, fantasia, 
entre muitas outras divisões, os quais possuem como função primordial causar o sentimento tão comumente relatado por Lovecraft: o medo.

Se colocarmos a definição de horror como sendo um intenso medo e dor, no estado físico, ou medo e desânimo, no estado psicológico, o gênero não pode ficar preso apenas nos conceitos sobrenaturais, pois o horror lidará com a humanidade, com a vida e aquilo que ela propicia ao ser humano. Tendo isso em vista, trataremos o horror como Todorov apresenta, deixemos de lado apenas a classificação por gênero, e nos foquemos naquilo de maior aderência desse tipo de escrita: a tendência em causar o medo.

Uma das mais usuais dúvidas entre os leitores e estudiosos do gênero horror/terror é exatamente essa diferença, o porquê de alguns títulos serem discriminados como horror e outros como terror.

Ann Radcliffe levanta que podemos fazer uma divisão primária de cada um dos gêneros dispostos, horror, então, trataria do medo em seu estado mais psicológico; o horror secreto do ser humano, o medo de olhar em baixo da cama, ou na fresta do guarda-roupa, ou, ainda, o medo de um estranho ou de um assassino serial, por exemplo. O terror, pelo contrário, trata de levar o leitor ao mundo dos monstros, das anomalias naturais e sobrenaturais, explorando o medo visceral do ser humano, do inevitável, daquilo que foge do seu conhecimento de mundo.

Por consequência, talvez a principal afirmativa dessa dificuldade em exemplificar o que é o horror seja a grande expansão que o gênero teve nos anos 80, com uma explosão de títulos explorando muitos temas clichês do gênero, fazendo a literatura do horror criar uma defasagem cultural em sua estrutura. Principalmente devido a seu caráter inicial, o gênero horror tinha como intuito assustar, e para isso os escritores deviam sempre estar modificando seus escritos para causar no leitor o sentimento de novidade, o sentimento de algo nunca visto, e tudo o que é novo deve ser temido, proporcionando, desse modo, o sentimento que o leitor procura.

\section{Da gênese a Poe}

O horror tem sua origem muito antes desses escritos que conhecemos como gênese do gênero. Os povos da antiguidade, que possuíam um sistema politeísta de crença, tinham os deuses como seres onipotentes, não 
diferentes de hoje em dia, e acreditavam que através da oferta em forma de sacrificios, os deuses os auxiliariam na colheita e em suas tarefas diárias. Entretanto, ao mesmo tempo em que esses deuses eram uma bênção, eles também traziam o terror àquelas nações, em suas crenças, acreditavam que se determinado deus não ficasse satisfeito com os sacrificios, ou não fosse possível completar o que era pedido pelo sacerdote, o Deus os puniria com destruição e terror. Desse modo, temos uma sociedade controlada pelo horror da destruição, e não pela benevolência de um ser supremo. Deve-se a isso o poder fantástico da psiquê do ser humano em crer no invisível, em reverenciar algo imaterial. Logo, é possível constatar que esses foram os primórdios do terror na história, o medo de algo incontrolável, que fazia todos se sentirem impotentes diante de tão grande poder.

Uma visão interessante disso é apresentada por Melo, no qual o autor mostra uma visão atraente quanto a esse tema:

Os deuses foram feitos para termos medo, pelo seu poder e pela sua influência. Uma vingança divina traz horror a um coração quente, pois o medo de ser o alvo disso condiciona a pessoa a nunca ir contra essas forças. Para ir contra elas, existem os heróis. Assim acontece com Beowulf, onde o grande herói luta contra um perigo que nenhum homem pode enfrentar; assim é com Hercules, com Teseu, com Siegrifield, com Vasco da Gama (em Os Lusíadas), entre outros. A figura do herói fará o papel de todas as pessoas que nele se enxergam, pois aquele herói será a sua representação para enfrentar algo que está além dele (MELO, 2007)

Logo observamos que o principal intuito de qualquer sociedade para sua sobrevivência, a criação do herói para salvá-los do mal que antes os ajudava, agora só traz destruição. Temos então uma visão histórica do que é considerado terror fantástico, ou sobrenatural, onde aquilo que se enfrenta é algo fora dos conceitos aceitáveis pela ciência.

Contudo, consideremos também como horror não apenas aquilo a que não se deve acreditar cientificamente, e se o horror for tão real quanto essa folha de papel, como o local onde moramos ou como os livros onde são escritos essas estórias, Stephen King em seu livro Dança Macabra (2007) falará exatamente isso, que o horror não precisa ser necessariamente aquilo fora do contexto do real, o horror é muito mais real do que muitos levam a crer, é tudo aquilo que nos faz refletir devido 
a certa situação, desde se devemos ou não abrir aquela porta, até a mais intensa discussão familiar. O horror real da humanidade é usado por King, o horror de perder alguém querido, ou, para alguns, seu herói, aquilo que você presa com tanto cuidado, e que lhe é tirado de forma abrupta e assustadora, quando o real se torna tão assustador, que o maior desejo daquele que vive o fato é fugir, e não encarar algo tão perturbador com a mente sã:

Atingimos a Idade Média, ou Idade das Trevas como é referenciado, na qual a Igreja criou a "santa" inquisição, e durante a qual, aqueles que diziam possuir poderes sobrenaturais, eram assassinados, por vezes de maneira sádica. Temos nessa época a criação das primeiras lendas, entre elas os vampiros, lobisomens, fantasmas, etc, que embasarão toda a literatura futura. Temos nessa época a caça às bruxas, um fato que marcou a humanidade, assim como afirma Melo:

Isso muda na Idade Média. Nela, a tradição oral dos povos dominados pelos cristãos incorporouse ao imaginário local. Passou ao estado de lenda, de sobrenatural, por fugir daquilo que as leis cristãs consideravam naturais. Então foi nesse período que vieram as figuras do vampiro, do lobisomem, dos espíritos, da bruxa, do mago, dos seres imaginários que podiam acabar conosco. Isso causava medo no homem cristão, uma vez que estava diante de algo que seu deus não conseguia conceber (MELO, 2007, negrito nosso).

Apesar de terem se passado vários séculos, as tradições não mudaram tanto quanto parece, o horror ocasionado pelos deuses, e os horrores causados por esses seres sobrenaturais funcionam praticamente da mesma maneira. O que isso causa naqueles que vivenciam é o sentimento de impotência diante do fato, parece que nada pode detê-lo, e nesse momento, assim como no passado eram criados heróis.

Avançando alguns séculos na história, passando da Idade Média ao século XVII, encontramos um dos primeiros escritores a adentrar nesse universo paralelo, Horace Walpole que, apesar de não escrever exatamente sobre esse tema, é de primordial importância para os escritores futuros. Em seu livro O Castelo de Otranto (1764), Walpole explora 
muito mais a ficção científica do que o horror em si. Entretanto sua influência extrapola seus escritos, sendo que a dimensão de sua influência é gigantesca, chegando a servir como modelo para grandes mestres como Edgar Alan Poe, Bram Stoker, Daphne du Maurier em The Loving Spirit e um número considerável de outros escritores. Um bom exemplo na literatura muito posterior a Walpole é o romance de Shirley Jackson $A$ Assombração da Casa da Colina.

Chegamos então a um escritor com extrema influência na literatura do horror, Matthew Gregory Lewis, que em sua obra Monk denuncia a inquisição espanhola, e com esse livro se torna extremamente conhecido recebendo o pseudônimo de Monk Lewis. As obras de Lewis tratavam o sobrenatural de maneira mais ofensiva, e sua visão era mais visceral que o de costume. Monk Lewis detalhava cenas sangrentas e sádica, além de criticar fortemente os ideais morais, religiosos e sociais da época, sua atmosfera era muito mais densa que seus antecessores, suas sombras, como é relatado no ensaio de Melo (2007), são eternas, e suas ações, violentas.

Avançamos então ao que, para a grande maioria dos estudiosos, foi o maior escritor de contos fantásticos: Edgar Alan Poe. Poe foi, e ainda é, a base concreta para grandes escritores de horror ao longo da história e suas obras servem como referência para conhecidíssimos escritores, tais como Lovecraft, Clive Barker, Anne Rice, Stephen King, e o brasileiro André Vianco.

A influência de Poe ultrapassa todos os ramos da história como sendo o mais conhecido escritor do gênero, autor de O Poço e o Pêndulo (The Pit And The Pendulum (1842)" e O coração Delator, além do poema The Raven (O Corvo, 1845)" Poe mostra seu estilo próprio de escrever, estilo esse que será usado como referência.

Em Poe encontra-se aquilo que é de maior aceitabilidade na literatura do horror, visto que sua obras tratam o sobrenatural de maneira subjetiva. Poe deixa o leitor imaginar as cenas de maneira própria, não lhe impondo nada, algo semelhante a Lovecraft, o qual deixa o "monstro" sem aparecer por vezes. As obras de Poe têm um teor poderoso de impessoalidade, comprovada por sua poderosa capacidade de fazer o leitor não perceber a existência de um narrador, como se o próprio leitor estivesse vivenciando o que a história narra. Além disso, suas obras exploram algo que será muito utilizado na literatura de horror: o suspense. 


\section{Três grandes nomes}

A partir de agora iremos tratar especialmente de três obras que formaram muitos dos escritores que hoje atuam, e que, ainda hoje, possuem suas ideias imitadas e usadas das mais variantes formas. Vejamos esse trecho retirado do livro de Stephen King, Dança Macabra, para darmos uma breve introdução a respeito da influência de tais obras no gênero horror:

Os três romances que eu gostaria de discutir nesse capítulo parecem ter realmente alcançado tal imortalidade... Todos os três experimentam um certo tipo de exclusão do iluminado círculo das obras literárias inglesas reconhecidas como "clássicos". Talvez por bons motivos. (KING, 2007, p. 51)

No princípio do capítulo da qual a citação acima foi retirada, King apresenta as obras que se tornaram verdadeiras lendas do gênero terror, Frankenstein, Drácula e O Médico e o Monstro, cada qual de maneira única. Ele irá refletir acerca da grande força que essas obras tiveram no intelecto geral dos escritores que vieram após tais obras, e como elas foram usadas como referência das mais diversas maneiras.

Iniciemos então de forma cronológica. Mary Shelley (Frankenstein: or the Modern Prometheus, 1818) utiliza a idéia da morte e ressurreição para nos trazer seu terror. Na obra, o doutor Frankenstein está obcecado com a ideia de criar vida, e seu conhecimento abrangente em medicina faz de sua ciência realidade, sendo que ele acaba por criar um monstro a partir de partes de corpos humanos, monstro esse que "nasce" a partir de uma cirurgia bem sucedida, ou não; contudo, esse monstro o assusta e acaba fugindo. O livro passará por diversas excursões e acabará na derradeira batalha entre o criador e sua criação. Mas o que nos vale nesse breve resumo dessa obra prima da literatura é seu valor para os futuros escritos; a ideia de "criar" vida, ou renascer dos mortos, será difundida de maneira consecutiva, e não apenas na literatura mas também para as telas do cinema. Mary Shelley mostrou que apesar de sua pouca idade - possuía 19 anos quando publicou Frankenstein -, seu talento era impressionante, e nem mesmo seu anonimato da primeira edição foi capaz de apagar isso. O que não se deve, por outro lado, é criar uma visão prematura da 
leitura devido à pouca idade da escritora. Acerca disso, Stephen King faz uma comparação interessante ao ritmo que Mary Shelley coloca em sua obra:

O romance de Mary Shelley é um melodrama de ritmo bem lento e prolixo, seu tema desenvolvido em tacadas largas, cuidadosas e até mesmo brutas. Ele se desenvolve da maneira como um estudante brilhante, mas ingênuo, defenderia seu argumento. (KING, 2007 p. 55)

Logo, é possível dizer que a obra de Shelley é uma das precursoras do tema monstro, muito utilizada na literatura do horror. Contudo, a criatura de Shelley possui desejos ambíguos, visto que por vezes ele é extremamente humano, chegando a ajudar pessoas e salvar uma menininha; em outras vezes ele se vê como um verdadeiro monstro odiado por todos, e escorraçado aonde fosse, até o desejo de possuir uma esposa de sua raça para satisfazer seus desejos mais primários. Indiferente de preceitos, temos nessa obra uma noção que terá importância de grande valia no futuro literário. As obras que irão usar como base as ideias de Shelley serão imensas, incontáveis poderia se dizer, entretanto o legado que essa jovem escritora deixou é inegável, e imitado de forma eficaz por poucos.

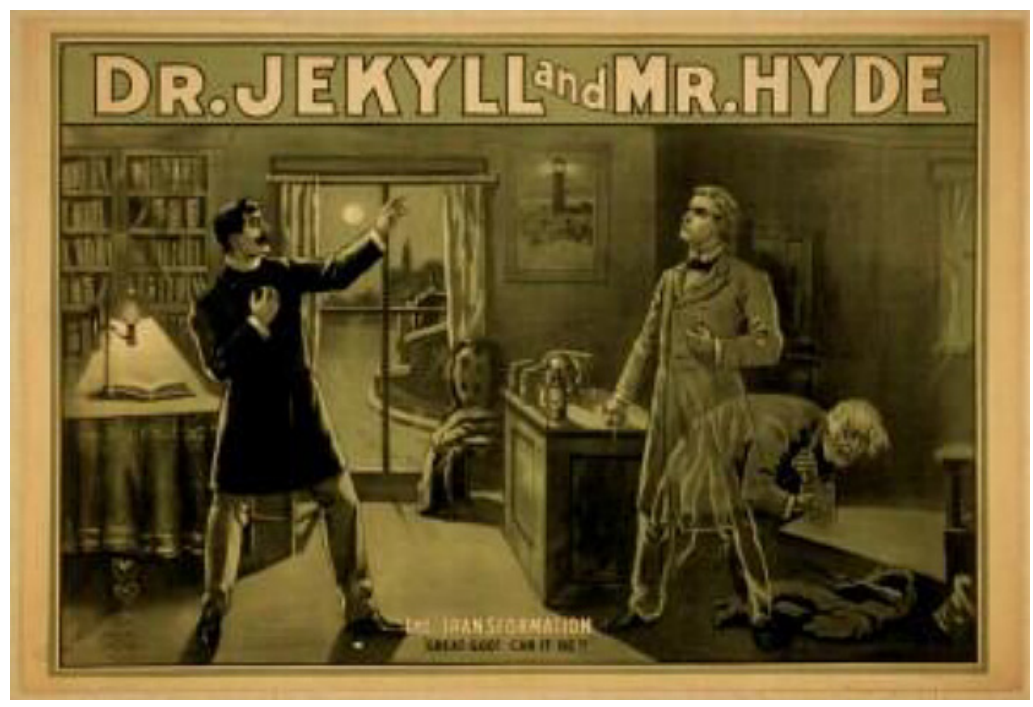


Passando então de monstros reais, físicos, para a psique monstruosa de um personagem estudado com afinco desde seu primeiro lançamento em 1886, temos O Médico e o Monstro de Louis Stevenson (The Strange case of Dr. Jekyll and Mr. Hyde). Nesse livro, o autor nos apresenta o que a pura maldade pode fazer quando toma o controle do ser humano. Dr. Jekyll é um personagem da aristocracia local, muito respeitado por ser considerado um exemplo de bons costumes. Entretanto, devido a uma de suas experiências, descobre que pode trocar sua imagem para outra completamente diferente de si, tornando-se o execrável Mr. Hyde. Contudo, o que ele faz com esse outro eu é de grande repugnância social, pois Jekyll experimenta várias sensações e ações, que não teria coragem de fazer com o estereótipo adquirido no decorrer dos anos. Todavia, o que ele não sabe é que essa nova personalidade começa a controlá-lo aos poucos, até chegar ao ponto em que a criatura toma conta de seu criador.

Mais uma vez temos a visão de um monstro, porém, desta vez, muito diferente do ser abominável de Mary Shelley. O monstro de Stevenson tem aparência humana, mesmo que por vezes o narrador tente descrevê-lo e não consiga, podendo ser facilmente considerado um transtorno bipolar do Dr. Jekyll, conforme afirma Magalhães (2010).

Observamos aqui uma excursão de Stevenson ao retratar um monstro fora dos padrões visuais. A criação de Stevenson primeiramente é apenas ficcional, obra de um cientista envolvido em seus experimentos, entretanto esse monstro toma a forma de algo muito maior, algo poderoso que transforma totalmente o plano personagem Dr. Jekyll em duas personalidades totalmente diferentes.

Todavia, o que essa obra realmente vale para essa pesquisa é seu caráter amplamente imitado, tanto na literatura como no cinema, logo podemos dizer que O Médico e o Monstro será uma das bases para futuros escritores. 


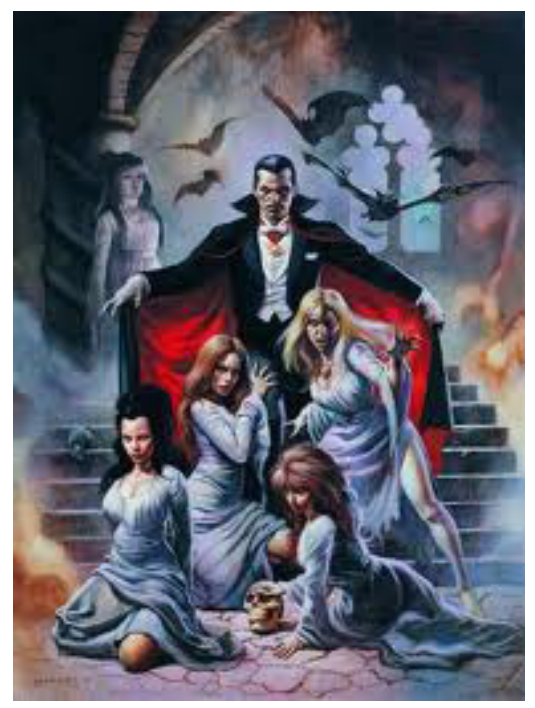

Como obra final desses três pilares do gênero horror, analisaremos aquela que vem sendo a mais utilizada e readaptada lenda no decorrer do tempo, o vampirismo. Drácula (1897), de Bram Stoker, aborda uma das criaturas mais difundidas como sendo o clássico do horror, e, mesmo sabendo que Stoker não foi o primeiro a escrever sobre a lenda, poucos discordam que ela não seja a mais bem escrita e, sem dúvida, a mais estudada no universo acadêmico.

Em Drácula, o que temos é a humanização do conceito de mal exterior (King, 2007, p. 61), já que todos os atos do conde Drácula são predestinados unicamente com vistas à maldade. Interessante também observar como ele não coloca o Conde em todo o livro, sendo que em dado momento o Conde praticamente desaparece da obra, reaparecendo apenas algumas vezes e no clímax final, fazendo assim o leitor ter a sensação do horror que não apenas é evidenciado pelas repentinas aparições do vampiro principal, como também, pelos outros personagens que antagonizam a obra - como a preferência alimentícia de Reinfield por insetos.

Temos nessa obra o estereótipo que será utilizado por muitos no futuro, infelizmente muitas vezes de maneira errônea, para criar personagens "vampirescos". Em Drácula é possível sentir toda a sensualidade que Stoker coloca na obra, criando aquele verdadeiro personagem que nos vem à mente quando pensamos num ser da noite, que sobrevive de 
sangue. Temos nessa obra o que se consagra como sendo a maior realizaçao sobre esse tipo de "monstro" e que será referenciada diversas vezes no futuro literário do horror.

Entre os escritores que falarão sobre vampiros após Stoker, teremos alguns que fizerem sucesso abordando esse tema. Entre eles, Anne Rice, famosa por seu vampiro Lestat e Stephen King, em seu romance $A$ Hora do Vampiro (2010). O cinema também nos presenteará com diversas adaptações "vampirescas" de qualidade, entre elas algumas muito famosas como M, o vampiro de Dusseldorf, de Fritz Lang, (1931) e Nosferatu, uma sinfonia de horrores, de Murnau (1922).

Como adendo, analisemos Howard Phillips Lovecraft, o qual é considerado um dos maiores nomes da literatura gótica. Suas obras retratam muito o passado mitológico, nas quais suas criaturas eram vistas com tanto poder que algumas chegavam a ser consideradas deuses. Muito disso se dá pela influência de Lord Dunsany, famoso escritor de contos fantásticos. Esses seres místicos criados por Lovecraft fizeram-no obter um termo próprio, os Cthullu Mythes, criado após a morte de Lovecraft pelo escritor August Derleth, variante de seu livro The Call of Cthulhu (1928). Esse foi o nome dado às lendas criadas por Lovecraft, e posteriormente imitadas por muitos.

O interessante de Lovecraft, e um dos principais atrativos de suas obras, é a visão conclusiva que ele tem com seu público. Lovecraft escreve sempre para assustar, tudo o que permeia a obra, a atmosfera, ambiente, clima, tem como finalidade primária levar o leitor aonde o escritor deseja. Acrescentamos que, na maioria de suas narrativas, o autor trabalha com a primeira pessoa. Lovecraft pode explorar toda a psique do personagem.

Todorov usa Lovecraft como exemplo de escrita que leva muito em consideraçao o ponto de vista do leitor. Ele afirma que, de acordo com diversos teóricos do gênero, Lovecraft invoca, frequentemente, o sentimento de medo e perplexidade, condições necessárias para que o gênero seja muito efetivo.

Para Lovecraft o critério do fantástico não se situa na obra a não ser na experiência particular do leitor, e essa experiência deve ser o medo. A atmosfera é o 
mais importante, pois o critério definitivo de autenticidade [do fantástico] não é a estrutura da intriga a não ser a criação de uma impressão específica. (...) Por tal razão, devemos julgar o conto fantástico nem tanto pelas intenções do autor e os mecanismos da intriga, a não ser em função da intensidade emocional que provoca. (...) Um conto é fantástico simplesmente se o leitor experimenta em forma profunda um sentimento de temor e terror, a presença de mundos e de potências insólitas. (TODOROV, 1981, p.20, negrito nosso)

Contudo, Todorov apresenta a visão de outros teóricos acerca do tema, todos eles concordando com o fato dessa literatura ter Lovecraft como ponto de referência, mas, também, apresentando seus pontos de vista. Peter Penzoldt diz que, com exceção do conto de fadas, todas as histórias sobrenaturais são histórias de terror que nos obrigam a nos perguntar se o que se toma por pura imaginação não é, depois de tudo, realidade (Todorov, 1981, p. 20). Ao mesmo tempo, pode-se considerar os argumentos de Caillois (Todorov. 1981, p. 21) que teoriza que a pedra fundamental do fantástico é a impressão de estranheza irredutível. Ambos os autores mostram como a maneira de escrever de Lovecraft é referência quando se fala no gênero fantástico do terror e do horror.

\section{O Horror moderno}

Chegamos à fase em que mais foram, e ainda são, lançadas obras do gênero, comecemos por uma famosíssima escritora que explorou muito bem um campo que há tempos não recebia uma boa obra, antes extraordinariamente bem explorado por Bram Stoker: a criadora de Interview with the Vampire (1976) Anne Rice.

Nesse meio tempo em que a história da literatura de horror passou com poucos livros que alcançassem o antigo âmbito a que essa literatura um dia pertenceu, Anne Rice aparece reinventando o romance gótico de forma a incorporar a estética moderna (Melo, 2007). Seu tema primordial são os vampiros e todos os sentimentos que eles possuem, suas paixões, motivações e lutas, entretanto num molde atual atraente tanto aos leitores assíduos dessa literatura, como aos novos leitores que ainda estão em processo de formação. 
Interessante é observar como Anne Rice apresenta seu principal personagem, Lestat de Lioncourt, como um vampiro não tão maligno como Drácula. Seu personagem tem vítimas específicas; ele as estuda e as escolhe principalmente por seus modos de vida. Com relação a esse fato, Danielle de Oliveira Costa (2010), em sua tese de Mestrado em teoria da literatura, faz interessante comparação entre Lestat e o personagem fictício de Oscar Wilde, Dorian Gray, ambos relatando a situação caçador e presa em que se apresentam perante a sociedade.

Constataremos então que após as obras de Anne Rice fazerem o grande sucesso que se tornou, seus temas serão cada vez mais utilizados pelos escritores futuros. Na realidade, são muito atuais os romances que tratam o mito vampiresco de uma maneira menos nociva do que foi tratado em seu início. Os vampiros das obras de hoje agem muito mais como humanos, exatamente como Rice tentava colocá-los em suas obras, e suas atitudes refletem ações pensadas paulatinamente.

Clive Barker é outro autor que vale a citação neste estudo. Ele irá explorar o visceral, o grotesco, o mortal do homem, coisa que ainda é pouco explorada (Melo, 2007). Com isso, ele conseguiu angariar uma legião de fãs, que estavam cansados das mesmas tramas de sempre, copiadas desde sempre. Para exemplificar isso, citamos o que a revista Fangoria revela sobre a escrita de Barker:

O trabalho de Barker combina a prosa rica de Straub com uma imaginação que não conhece limites. Adicionemos ainda algumas alfinetadas com humor negro e uma sabedoria afiada, e teremos uma idéia dos horrores de Clive Barker. (TIMPONE, 1997, p. 124)

Com essa análise em mente, podemos ter uma breve noção do estilo sangrento desse escritor. Os textos de Barker normalmente são carregados com o erotismo capaz de causar ânsia aos olhos não acostumados com seus livros. Tudo isso, aliado a um senso de inteligência muito apurado, tornam as obras de Clive Barker muito bem posicionadas no âmbito mundial do horror.

King talvez seja considerado por muitos o maior escritor do gênero fantástico, citado e estudado por diversos e renomados pesquisadores. $\mathrm{O}$ autor é considerado praticamente uma lenda viva da literatura de horror, 
não apenas por seus livros proporcionarem temor para todas as idades, mas por sua poderosa capacidade de fazer o leitor permear o caminho que ele desejar enquanto lêem um de seus livros.

Citar uma obra em especial de Stephen King se torna uma tarefa devéras difícil, não apenas pelo exacerbado acervo que ele possui, mas também porque as opiniões são das mais diversas. Alguns diriam, sem sequer hesitar, que $A$ Dança da Morta é sua maior obra de arte, outros seriam relutantes quanto a isso e indicariam $A$ Coisa, mas não estamos aqui para discutir se uma obra é melhor do que a outra, o autor experimentou tantos caminhos, nas mais diferentes obras a que se arriscou, que sequer podemos tachá-lo como escritor de um único gênero. King escreve terror em sua maioria, e os exemplo são praticamente inumeráveis, com o perdão da hipérbole, mas ele também se consagrou extremamente famoso por suas inserções em outros gêneros, o suspense e a fantasia, vide $A$ Torre Negra por exemplo.

Alguns se perguntam nesse ponto se essa variação de gêneros fez com que o escritor perdesse sua capacidade de assustar, mas o que muitas podem responder com perfeita sincronia é que não já que King possui um estilo mutável, mas sempre surpreendente, sempre pronto para pegar o leitor de surpresa e arrancá-lo de sua zona de conforto.

É claro que essa pequena viagem pelo mundo da ficção do horror não pode abordar todos os escritores do gênero e, deste modo, muitos conhecidos dos fãs ficaram de fora desta análise, a exemplo de Nathan Drake (Literary Hours) Peter Straub (Ghost Story), Shirley Jackson (A Assombração da casa da colina), Ira Levin (O bebê de Rosemary), Ray Douglas Bradbury (Fahrenheit 451). É realmente impossível citarmos todos nesse espaço, contudo, o que é passível de afirmação da literatura de horror é que ela sempre existiu, em melhores ou piores graus, e vem cada vez mais atraindo fãs de todas as idades, tornando assim essa área da literatura cada vez mais atrativa para pesquisas e análises. 


\section{Bibliografia}

Barker, C. Livros de Sangue. EDITORA CIVILIZAÇÃO BRASILEIRA S.A, 1990.

França, p. D. O horror na ficção literária: Reflexão sobre o "horrível" como uma categoria estética. XI Congresso Internacional da ABRALIC Tessituras, Interações, Convergências, 13-17 de Julho de 2008, p. 1.

King, Stephen. Dança Macabra. Rio de Janeiro, Brasil: Objetiva, 2007.

LOVECRAFT, Howard Phillips. Supernatural Horror in Literature. New York: Dover Publications, 1973.

Raškauskienè, Audronè. Gothic Fiction The Beginning. Gothic Fiction The Beginning. Kaunas, Lituania, 2009.

Timpone, Anthony. Fangoria - Mestres do terror. Nova York: Mercurio Ltda, 1997.

TODOROV, T. Introdução a Literatura Fantástica. Perspectiva, 1981.

Beghini, M. (30 de Março de 2010). A Literatura de Terror e a

Comunicação. Disponível em the boy with the blues: http://theboywiththeblues.blogspot.com/2010/03/literatura-de-terror-e-comunicacao.html. Acesso em 22 de Outubro de 2010,

Costa, Danielle de Oliveira (s.d.). Dr. Polidori, Stoker, Rice: as metamorfoses do mito do vampiro no Século XIX e XX. Disponível em Letras, Ufrj: http://www.letras.ufrj.br/ciencialit/ensaios/vampiro_do_coloquio.doc. Acesso em 30 de Junho de 2010

Magalhães, Leonardo A leitura enquanto alegoria/parábola. disponível em leitura e escrita e traduçoes. http://leoleituraescrita.blogspot. com/2010/03/sobre-o-medico-e-o-monstro-dr-jekyll-mr.html. Acesso em 28 de Junho de 2010,

Melo, Fabio. (25 de Julho de 2007). Textos. Disponível em Recanto das Letras: http://recantodasletras.uol.com.br/ensaios/578321. Acesso em 26 de Junho de 2010. 


\section{Imagem}

Disponível em http://t0.gstatic.com/images?q=tbn:ANd9GcRKeYLRpxy7fxVJEZNtzsBLBcqT34ICh1rDzPh0SSFM3vNFCCtxJg. Consultado em $09 / 10 / 2012$

Disponível em http://armonte.files.wordpress.com/2010/03/jekyll-and -hyde1.jpg. Consultado em 09/10/2012.

Disponível em http://t0.gstatic.com/images?q=tbn:ANd9GcTT6sw9bFxrt9W9CtamxX3OWGenMcxoZh7USUMhYvPj6Zo7_jDV. Consultado em $09 / 10 / 2012$ 


\title{
A representação do Diabo no conto $A$ Igreja do Diabo de Machado de Assis e no romance Grande Sertão: veredas de Guimarães Rosa.
}

\author{
Ricardo Gomes da Silva (UEL)
}

"Eu penso se o Diabo não existe, foi simplesmente criado pelo homem, este fez à sua imagem e semelhança."

Dostoiévski

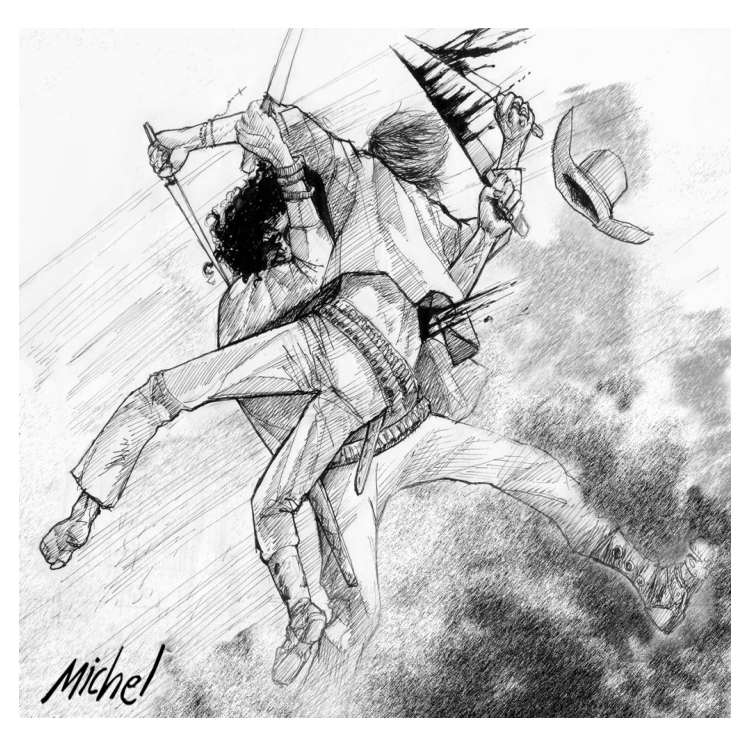

O Diabo ocupa um constante e importante lugar no imaginário da cultura ocidental. Não menos constante e importante é seu lugar na literatura, sobretudo durante e após a Idade Média. São tantas as representações do Diabo na literatura que podemos afirmar a existência de uma espécie de categoria dos personagens-diabo. "Categoria de personagem" e não simplesmente personagem, pois as representações do Diabo na literatura 
são as mais diversas possíveis. Quando se fala em Diabo não se fala de um personagem único, mas de um conceito a ser livremente desenvolvido. Dante em $A$ divina comédia desenha a sua maneira o Diabo, Milton em $O$ paraíso perdido o pinta de outra forma. Diferente será também o desenho do Diabo em O Fausto, de Goethe, ou Litanias de Satanás de Baudelaire, o mesmo se dará na obra de Shakespeare, de Thomas Mann, Paul Valéry, Walter Scott, Allan Poe, Gil Vicente, Fernando Pessoa, Saramago.

$\mathrm{Na}$ literatura brasileira os personagens-diabo estão presentes em diversas obras, e em especial em conhecidíssimas e marcantes narrativas de Machado de Assis e Guimarães Rosa, em A igreja do diabo e em Grande Sertão: Veredas. E assim como as tantas outras representações do Diabo, realizadas por diversos escritores, são diferentes uma da outra. Podemos dizer que personagem-diabo machadiano é tão diferente do rosiano ao ponto de ser oposto. Mas de que forma isto ocorre? De que maneira estes personagens-diabo são diferentes? Estes e outros pontos que concernem a questão oposição das figuras do diabo presentes em $A$ igreja do diabo e em Grande Sertão: Veredas nosso objetivo neste artigo.

Partimos, então, da definição do conceito de representação rumo à análise dos nossos objetos. O pensador francês Roger Chartier (2002) ao teorizar sobre o conceito de representação afirma que representar é criar uma imagem de algo, na qual haverá uma relação decifrável entre a imagem e o que ela significa. Em outros termos representar é criar signos que remetem a algo. As letras, sílabas e palavras que vemos nesta folha são representações de vocalizações verbais que foram construídas para representar ideias, objetos, lugares, pessoas, etc. Desta maneira a escrita é uma representação visual das palavras que por sua vez são representações verbais de coisas concretas e abstratas.

A literatura, por definição, está intrinsecamente envolvida nestas relações de representação. As discussões neste sentido são diversas e vêm desde Platão ${ }^{1}$ - ao condenar a poesia por se tratar de imitação - até os ideais dos escritores Realistas na busca da representação na literatura da realidade de forma mais impecável possível.

Desta forma podemos afirmar que o Diabo, enquanto uma entidade abstrata, é a representação de algo. Na realidade a ideia de Diabo nasce 
como uma representação para posteriormente ganhar status de entidade. Neste sentido a representação do Diabo na literatura se faz de forma extremamente complexa. Pois, na literatura acaba-se por representar a representação que se tem de uma entidade que por sua vez também representa algo. Para não nos perdemos nisto que mais parece um jogo de palavras façamos-nos duas perguntas básicas: O que o Diabo representa? Como o Diabo é representado?

Dizer apenas que o Diabo representa o mal seria simplificá-lo por demais. Neste sentido o livro O Diabo no imaginário Cristão nos fornece o panorama histórico necessário para compreendermos a estrutura da figura do Diabo. De acordo com NOGUEIRA (1986) na antiguidade não se tem registro de alguma figura que pudesse correlatamente representar o mal. Tratando-se de textos bíblicos, no Antigo Testamento a única contribuição que se tem a personificação do mal se encontra no Livro de Jó. O Anjo "Satã" - que significa aquele que acusa ou que calunia - levanta a suspeita perante o Senhor de que um de seus servos seria fiel por interesse. A partir do Novo Testamento passa-se a se evidenciar a existência de um ser como símbolo do mal. É quando surge o termo diabo, do grego Diabolos, que significa aquele que leva o juízo. Neste sentido, a passagem de Jesus no deserto sendo tentado pelo Diabo é uma das que mais contribuirão para formação desta personificação do mal.

Até a Idade Média se desenvolvem uma série de textos não canônicos acerca das Legiões de Demônios e do Apocalipse. Com o passar do tempo pensadores da Igreja Católica como Eusébio, Cipriano e Tertuliano começam a se preocupar e escrever sobre o Diabo. Tem-se então o que NOGUEIRA (1986) chama de Institucionalização do Diabo. É neste período que surgirá a tardia leitura da Serpente como um dos disfarces do Diabo. E como o Diabo passa a ser culpado pela Igreja por todas as desgraças, desde pestes a desastres naturais, começa-se a implantar o medo de sua figura. Contudo, a excessiva evidenciação da figura do Diabo faz com que ele cresça mais e mais no imaginário coletivo, transformando-o em uma gigantesca e assustadora criatura maligna.

A quase que onipresença e onipotência adquirida pelo Diabo neste período ao mesmo tempo em que farão com que ele arrebate uma multidão de tementes lhe renderão sociedades secretas de adoração. A evolução 
destas sociedades de adoração ao Diabo originará a imagem Moderna do Diabo. Assim o Diabo passa a simbolizar a negação a tirania de Deus. Satã será visto como símbolo de espírito livre em oposição à instituição religiosa cristã. Será também o diabo transformado em sinônimo de progresso, liberdade, ciência e anti-herói, o herói rebelde, o deprimente Anjo caído.

Quanto as representações do Diabo quem nos auxilia a pensar é Umberto Eco em dois subcapítulos de Historia de la fealdad intitulados Las metamorfosis del diablo e Del satanás rebelde al pobre Mefistófeles.

As metamorfoses do Diabo apresentadas e discutidas por Umberto Eco mostram como o modo que o diabo é representado está ligado às nuanças do que ele representa. Neste sentido o pensador italiano explica que embora o Diabo esteja ligado à maldade, nem sempre é descrito com aspectos monstruosos. Estando a imagem do Diabo ligada à calunia ou à sedução ele poderá ser representado com aspectos de feiúra reduzidos ou mesmo como uma belíssima mulher. Por vezes ainda que o Diabo é representado como uma criatura carnavalesca: alegre, dançante e divertida.

ECO (2007) vê nas representações do Diabo por Dante e Tasso a imagem de um ser majestoso. Em A matança dos inocentes (1632), de Marino, o Diabo é representado "como un ser sobre el que pesa una profunda tristeza, y que ello en cierto modo nos inspira piedad."(ECO, 2007, p.179). Em O Paraíso Perdido (1667) de Milton, o Diabo inspira de um "sentimiento de venganza y de afirmarción del propio Yo, pero sin duda un modelo de pura energia en rebelión" (ECO, 2007, p.179). Estas representações vão ao encontro com a adoração e aproximação do Diabo no mundo moderno notada por NOGUEIRA (1986).

O último estágio de metamorfose deste "ser" é o de "pobre diabo". De acordo com ECO (2007), estágio este iniciado por Goethe ao atribuir ao Diabo qualidades demasiadamente humanas. A imagem de Mefistófeles, um Diabo medíocre dotado da mesquinhez de um pequeno-burguês, será o modelo às representações de Dostoievski, Giovanni Papini e Thomas Mann.

Temos a partir de ECO (2007) e NOGUEIRA (1986) duas representações básicas e opostas do Diabo: Medieval X Moderna. O Diabo, 
sinônimo de maldade na Idade Média representou algo a se temer e respeitar. Já na Modernidade passou a representar algo a se identificar e se compadecer.

Esta base opositiva (temor e respeito $\mathrm{X}$ identificação e compadecimento) nos dá suporte para pensarmos no contraste dos personagens-diabo do conto A igreja do diabo de Machado de Assis e do romance Grande Sertão: Veredas de Guimarães Rosa. A oposição da representação do Diabo nestas duas obras pode ser pensada a partir da dicotomia de representações: Idade Média X Modernidade. A representação machadiana acompanha uma visão Moderna do Diabo, enquanto a representação rosiana está mais ligada ao viés Medieval.

Como é próprio das narrativas alegóricas (fábula, apólogo, parábola), em $A$ igreja do diabo são adotadas as premissas do Maravilhoso (vide a definição de TODOROV), onde os acontecimentos "sobrenaturais" não subvertem a verossimilhança interna, ou seja, não causam estranhamento. Não questionamos o fato de como esta história pode constar num manuscrito beneditino, quem a presenciou se ela demorou séculos, como foi possível alguém entender a língua que Deus e o Diabo conversam. Aceitamos a história sem nos questionarmos sobre isto, pois ao interpretamos uma narrativa alegórica procuramos apreender seu teor moralizante ou pedagógico.

O pacto em Fausto de Goethe possui também este viés alegórico. A aparição de Mefistófeles não entra em choque com as leis de verossimilhança internas da peça. O Diabo se metamorfoseia de cachorro em um distinto homem sem causar-nos estranhamento.

O alegórico nestas obras de Goethe e Machado concede ao Diabo voz, forma, existência e contornos quase humanos. Tudo isto contribuirá para a formação das imagens de pobres diabos que são. Decadentes e deprimentes ambas são representações Modernas do Diabo. O personagem-diabo machadiano de início lamenta com Deus: "Estou cansado da minha desorganização, do meu reinado casual e adventício. É tempo de obter a vitória final e completa.” (ASSIS, 1977, p.59). Ao final, após constatar a decadência de sua igreja, volta a Deus mais triste e frustrado do que no início. 
Da mesma forma, os ínfimos poderes de Mefistófeles de Goethe nos diálogos que ele trava com Fausto:

\section{FAUSTO}

Já sei o que és, e qual teu nobre empenho.

Como não podes destruir o todo, pões-te a tomar desforra em ninharias.

\section{MEFISTÓFELES}

Consigo pouco, é certo. O oposto ao Nada, O Que quer que é que existe, o mundo bronco, por mais que em vulnerá-lo me desvele, fica-me sempre ileso. Em vão lhe arrojo ondas, procelas, fogos, terremotos; ao cabo, terra e mar ficam serenos. Pois a relé nojosa, a corja humana! Não há meter-lhe dente. Ando, há que tempos, a matar neles, sem parar na faina, e a espécie a medrar sempre em sangue, em forças. É para endoidecer! De ar, água, e terra, do quente e frio, do húmido e do seco mil germes brotam... Se não pilho o fogo, ficava-me sem nada.

\section{FAUSTO}

E opões à força eterno-activa, criadora, amante. pobre demónio, o punho teu fechado! Busca outro ofício, aborto vil de caos. (GOETHE, 1949, p. 85-6)

Ou seja, tanto pelo viés alegórico de $A$ igreja do diabo, que nos permite aproxima-lo de trejeitos humanos, quanto pela própria figuração enquanto ser decadente, notamos mais similaridade desde personagemdiabo com a representação Moderna do que com a Medieval. Da mesma forma, o majestoso personagem-diabo Diabo de Grande Sertão: Veredas tem mais a ver com a representação Medieval. 
Um dos principais indícios do personagem-diabo rosiano se tratar de uma representação Medieval reside na questão do pacto. $\mathrm{O}$ receio que se tem em combater Hermógenes, uma vez que este tem pacto com o Diabo, é acima de tudo respeito e temor às supremas forças diabólicas. "Pactário ele era, se avezando por cima de todos."(ROSA,2001, p.424) diz Riobaldo acerca de Hermógenes.

O pacto, ou a tentativa de pacto, de Riobaldo será com o intuito de conseguir as forças equivalentes as de Hermógenes. A lógica deduzida é a seguinte: O Diabo é tão poderoso que só há uma maneira de vencer seus pactários, sendo também um.

Deus é lembrado por Riobaldo no momento do pacto, mas é nome do Diabo que ele grita: - "Ei, Lúcifer! Satanás, dos meus Infernos!" (ROSA, 2001,p.438). Riobaldo na incerteza do pacto pensa na imagem de Deus, mas em seguida percebe que somente o Diabo poderá lhe ajudar. O medo do Diabo em detrimento da fé em Deus nos remete as primeiras Sociedades Secretas de Adoração ao Satanás. Em um primeiro momento tais sociedades secretas consistiam numa estratégica maneira de se por ao lado do mais forte: assim como Riobaldo tenta fazer.

Outro indício que liga Grande Sertão: Veredas à representação Medieval do Diabo é a sua onipresença. Desde o subtítulo até as últimas linhas do romance o personagem-diabo está presente. O diabo parece ser uma das preocupações mais constantes de Riobaldo. Ele fala o tempo todo sobre o Diabo, sobre sua existência ou não. Talvez esta seja uma das preocupações mais constante de Riobaldo, por conta do medo de que se o Diabo realmente existir, signifique que sua alma foi mesmo vendida.

Nestas duas obras temos a sinterização das duas principais e opostas representações dos personagens-diabo: a Medieval e a Moderna. Temos o que podemos chamar, a partir de Eco e Nogueira, de uma Moderna representação do Diabo em $A$ igreja do diabo. A voz, as feições e as fraquezas humanas, que ao mesmo tempo aproximam a representação do Diabo de nós, o transforma num ser decadente. Oposta a esta representação do Diabo é a de Grande Sertão: Veredas na qual o Diabo se aproxima da sua imagem Medieval por figurar como imponente, temível, reinante sobre os homens. 


\section{Bibliografia}

ALMEIDA, Marcos Renato Holtz de. As metamorfoses do diabo: a secularização do mito e sua apropriação pela indústria cultural no século XX. Tese (Doutorado em Sociologia). UNESP,Araraquara. 2008.

ASSIS, Machado de. A igreja do diabo. In: Histórias sem data. Rio de Janeiro: Civilização Brasileira, 1977.

CHARTIER, Roger. À beira da falésia. A história entre certezas e inquietude. Porto Alegre: Editora Universidade UFRGS, 2002

ECO, Umberto. Historia de la fealdad. Barcelona: Ed. Mondadori, 2007

FERRAZ, Salma. O Diabo na literatura para crianças. Linguagens Revista de Letras, Artes e Comunicação. v. 1, n. 3, p. 220-238, set./dez. 2007.

GOETHE, Johann Wolfgang von. Fausto. São Paulo: W. M. Jackson Inc., 1949.

NOGUEIRA, Carlos Roberto F. O Diabo no imaginário cristão. São Paulo, Ática, 1986.

PLATÃO. A República. São Paulo: Nova Cultural, 1999.

ROSA, Guimarães. Grande sertão: Veredas. Rio de Janeiro: Nova Fronteira, 2001.

\section{Imagem}

Disponível em http://1.bp.blogspot.com/_J9VoWoDbxps/R1GGq1fiwLI/ AAAAAAAAAEg/frLSHoymPpg/s1600-R/solto+na+rua3.jpg. Consultado em 07/10/2012. 


\section{A Personificação Demoníaca de Deus em "Poemas malditos, gozosos e devotos", de Hilda Hilst}

Paullina Lígia Silva Carvalho ${ }^{1}$

Eu sou a faca e o talho atroz!

Eu sou o rosto e a bofetada!

Eu sou a roda e a mão crispada,

Eu sou a vítima e o algoz!

(Charles Baudelaire, In: As Flores do Mal).

Ama mas crucifica.

Quase sempre assassino.

É Deus.

(Hilda Hilst, In: Poemas Malditos, Gozosos e Devotos).

\section{Introdução}

As antinomias vida/morte, eternidade/finitude, bem $/ \mathrm{mal}$, assim como, as personificações dessas ideias atreladas as imagens de Deus ou do Demônio, sugerem um tipo de lógica fundante no pensamento mítico e religioso, cujas formas primitivas eram motivadas não pela dualidade do pensamento linear, mas por sincretismos que visavam o sentido de unidade, inseparabilidade, do que seria a compreensão do Todo. Desta maneira, as funções metafóricas da linguagem simbólica e alegórica comum ao mito, à religião e à arte, constroem hermenêuticas capazes de sondar o Inefável, o maravilhoso, harmonizando na consciência

1 Graduada em Letras (UEPB) e Mestranda do Programa de Pós-Graduação em Literatura e Interculturalidade - Universidade Estadual da Paraíba 
humana o que o pensamento objetivante nega por não saber expressar, sem, todavia, conseguir silenciar, encerrar, os questionamentos em torno da experiência transcendente.

Não obstante, as representações feitas por imagens icônicas ou narrativas fabulares vibram o poder do dizer poético capaz de materializar o abstrato e unir os desiguais em um mesmo objeto simbólico: a palavra poética, vista como tentativa de captar o elemento enigmático da vida. $\mathrm{Na}$ obra da autora brasileira Hilda Hilst, opondo-se ao monoteísmo religioso e demais discursos institucionalizantes, a singularidade herética e blasfematória das representações de Deus, assim como a busca pelo Sagrado, posto em diversos textos como um interlocutor privilegiado, revela a heterogeneidade do elemento divino que não é mais estático ou inquestionável como o é a figura de Deus na tradição dogmática mítico-religiosa de diversos segmentos culturais e sistemas de crenças (cristã, judaica, mulçumana).

A palavra poética hilstiana encontra a causa secreta que une os opostos em uma unidade original, não constituindo um subterfúgio, mas formas de desmistificação do sagrado que o pensamento dogmático não é capaz de alçar. No livro Poemas Malditos, Gozosos e devotos (1984), o eu poético hilstiano questiona as motivações dos feitos de um deus-criador, que pode ser compreendido como uma personificação do Deus judaicocristão, cujos traços obscuros revelam uma divindade capaz de (re)unir em si as contradições mais diversas como, por exemplo, a de quem "ama mas crucifica" (HILST, 2004, p. 29). Buscamos, assim, compreender em que medida o elemento sagrado nos poemas de Hilda Hilst se reveste de características vistas como tipicamente diabólicas, de modo que o texto literário passa a desconstruir e rearrumar as formas cristalizadas da imagem de um deus, posto pelo monoteísmo religioso, como Único e imutável, além de inacessível pela sua soberania.

Para um estudo mais aprofundado em torno das personificações do divino no imaginário ocidental, interessa-nos, inicialmente, as considerações de Mielietinski (1987), uma vez que estas nos apontam um caminho para as representatividades míticas dos deuses e heróis-demiurgos dentro de um universo de valores primitivos, cujas imagens reúnem em si características diametralmente opostas, tornando todo personagem mítico, herói-demiurgo, divindade ou ancestral totêmico, um duplo caracterizado pela ambivalência de polos positivos e negativos. Buscamos, neste primeiro momento de articulação teórica, caminhar em encontro com o elemento divino no âmbito das narrativas mítico-bíblicas que fomentaram no Ocidente as ideias de Deus e do Sagrado para, em seguida, 
reencontrar estes a partir das (re)apresentações vistas na experiência mística e poética do livro Poemas Malditos, Gozosos e Devotos, de Hilda Hilst.

\section{As faces do divino e o lugar do sagrado nas narrativas míticas}

Suprimir os paradoxos culturais, seja dentro de um sistema de crenças mítico-religiosas, ou mesmo por meio de práticas políticas, constitui uma ação característica de totalitarismos que visam exercer controle e domínio sobre os modos de vida dos indivíduos, utilizando-se, para tanto, de discursos normativos e institucionalizantes que legalizam determinados modos de ser e exercícios de significação do mundo. A des-institucionalização dos textos, vistos como narrativas sagradas canônicas, a exemplo daqueles que compõem a Bíblia Hebraica e em parte a Bíblia Cristã, é o caminho que nos leva a questionar não apenas as interpretações e significações em torno do mito fundador das religiões, mas também verdades que fomentaram no Ocidente ideias de deus e cultura. Segundo Mielietinski (1987), aquilo que compreendemos como "os eventos dos tempos míticos, as aventuras dos ancestrais totêmicos, heróis culturais, etc., são um original código metafórico através do qual se modela a estrutura do mundo, natural e social". (MIELIETINSKI, 1987, p. 199-200).

Desta maneira, resgatar o elemento divino fora da normatividade dos segmentos religiosos, com o intuito de interpretar para além das "desleituras institucionais", nos reportando a um termo Haroldo Bloom e David Rosenberg (1992), implica em um exercício hermenêutico que vise antes de tudo o alcance do caráter lendário do mito religioso, exigindo, para tanto, uma leitura que se dê a partir de critérios estéticos capazes de nos revelarem a personificação da personagem divina em suas ações dentro das narrativas (des)sacralizadas, de tal forma que possamos nos afastar das interpretações homogeneizantes do caráter e da ação de um deus-criador estático e absoluto, como foi construída a imagem do divino no âmbito do discurso religioso normativo.

Haroldo Bloom e David Rosenberg (1992) nos apontam, ao investigarem as representações de Yahweh nos textos da tradição Javista, quão omitidas foram certas multiplicidades do caráter e da ação de Deus nos textos bíblicos canônicos, revisados e revistos por ideologias religiosas. 
Confrontando estes textos canônicos com as narrativas lendárias escritas, como defende os críticos, por uma autora denominada $J$, sendo esta a responsável pela construção ou reescrituras das arque-histórias bíblicas, somos interpelados antes de tudo pela ambiguidade da persona divina em formas narrativas marcadas pela ironia e pelos confrontos que destronizam o Supremo. Sobre o elemento contraditório suprimido nas narrativas canônicas, Bloom e Rosenberg (1992) nos dizem:

Se a história da religião é o processo de escolhas de formas de adoração a partir de fabulas poéticas, no Ocidente essa história é ainda mais extravagante: ela é adoração, em formas amplamente modificadas e revistas, de um personagem literário extraordinariamente inconstante e estranho, o Yahweh de J. (BLOOM E ROSENBERG, 1992, p.24).

Suprimir o elemento estranho da personagem de Deus nos textos míticos torna-se um trabalho incessante e quase impossível para os interpretes oficiais dos mitos bíblicos, uma vez que o inconstante, o transitório e o diverso parecem mover toda a narrativa, mesmo as canônicas. Atribuindo papéis a certas forças ou personalidades torna-se mais coerente para manutenção de uma estrutura do pensamento linear do que propriamente para significação do divino nas metáforas textuais, em que as imagens da personagem de Deus revelam paroxismos e conflitos latentes. Como exemplo, podemos tomar ação de Deus no livro de Jó, em que Este se move pela perversidade de testar a fidelidade do seu servo até os mais severos castigos gratuitos.

Mielietinski (1992), ao investigar a estrutura do pensamento mítico, afirma que:

A lógica mitológica opera amplamente com oposições binárias de qualidades sensoriais, superando a "continuidade" da percepção do mundo ambiente mediante a distinção dos "quadros" discretos com sinais opostos. Esses contrastes semantizam-se cada vez mais e tornam-se ideológicos, convertendose em meios diversos de expressão das antinomias fundamentais do tipo vida/morte. A superação dessas antinomias através de uma moderação progressiva, i.e, da localização sucessiva de mediadores 
mitológicos (heróis, objetos), que combinam simbolicamente traços dos polos, é uma manifestação nítida da bricolage. (MIELIETINSKI, 1992, p.195-196).

Dentro da unidade do tempo mitológico, cujo campo semântico caracteriza-se pela estabilidade dos sentidos primários e essenciais, o princípio da bricolage, referido por Mielietinski (1992) com base nos estudo do antropólogo Lévi-Strauss, surge como uma espécie de ação unificadora posta como subterfúgio para os conflitos entre dualidades, que não são necessariamente oposições binárias, mas forças que fluem de um só tempo infinito. As representações fantásticas do mundo dentro deste campo semântico estável, que é o tempo mitológico, possibilitam harmonizar os extremos em uma unidade original a partir de um retorno a acontecimentos de um passado mítico fundador. No contexto desse tempo mítico, as figuras dos heróis e deuses demiurgos desempenham uma espécie de papel de sintetizadores/mediadores dos contrários, sendo justamente a ambivalências dessas imagens que "mantém a função simbólica na solução das antinomias fundamentais da própria lógica da narração”. (MIELIETINSKI, 1992, p.208).

De acordo com os estudos de Campbell (2002, p.277), "nas tradições mais antigas, não existe essa separação dualista de poderes e, nós, em nossa forma de pensar, herdamos algo desse dualismo de Bem e Mal, Deus e Diabo, dos Persas". Todavia, o duplo dos heróis e deuses demiurgos não foi totalmente suprimido pelo pensamento e concepções de tempo histórico-cientificizante do Ocidente, considerando que o "pensamento mitológico é por princípio a-histórico, desconhece a heterogeneidade histórica, (portanto) reduz todas as múltiplas mudanças do tempo empírico profano a atos únicos da criação, realizados no tempo mítico sagrado e transcendente." (Idem, p.205).

Neste sentido, o campo semântico do tempo mitológico é um só em todas as culturas, operando-se através de sincretismos que envolvem os paradoxos e antinomias em só fluxo de sentido. Demonismo e cosmismos, assim como o surgimento de divindades demiurgas superiores, tornam-se forças ambivalentes oriundas de um só tempo infinito. (cf. CAMPBELL, 2002, p. 213). Tal é a lógica do tempo mítico fundante nas narrativas bíblicas, de forma que mesmo o modo de compreensão fundada em um tempo linear característico do pensamento ocidental 
não pode negar totalmente as marcas dos sincretismos do pensamento fundado em uma concepção de tempo mítica, visto que mesmo os mitos das tradições monoteístas são regidos por esse fluxo do pensamento que viabiliza o encontro com o Todo.

Questionar a autenticidade do pensamento dualístico é o caminho que nos leva não apenas a uma unidade original baseada em uma concepção mítica do tempo, ou ao mero exercício de correlação dos textos bíblicos hebraicos e do mito cristão com outros modos de representações primitivas, porém ao reconhecimento de diferentes forças ocultas atuando em uma mesma narrativa que nos revela diferentes dimensões do sagrado. Portando-nos, mais uma vez, aos estudos de Campbell (2002) estes nos apontam que há, claramente, mesmo nos textos canônicos hebraicos duas forças ocultas manifestando-se enquanto elemento maravilhoso: uma oriunda de uma divindade sobrenatural transcendente, outra da relação com a natureza em cultos pagãos.

Deste modo, as interpretações de dados elementos simbólicos associados a esta ou aquela divindade não excluem experiência do sagrado atrelado a diferentes forças ocultas, como o sagrado enquanto elemento maravilhoso na natureza, tornado em força demoníaca. A demonização da natureza não exclui a dimensão sagrada que esta assume nem mesmo nas narrativas míticas bíblicas canônicas, Campbell (2002) evidencia

o fato de que em nossa herança europeia cristã tivemos duas mitologias do oculto completamente diferentes para assimilar: a semítica, levantina, de um deus sobrenatural, absolutamente em oposição aos poderes pagãos da natureza, e depois, em contraste com isso, a visão, herdada dos gregos e romanos, de Dionísio, aquela prefiguração do próprio diabo, como uma divindade a ser de algum modo colocada em equilíbrio e em acordo com o deus da luz do clássico mundo apolíneo. (CAMPBELL, 2002, p.279).

Defrontamo-nos, assim, com o limiar de um pensamento fronteiristico, cuja demarcação entre os signos do sagrado e do profano, do divino e do demoníaco, transpõe-se de acordo com as variações das concepções simbólicas de tempo nas narrativas míticas e, consequentemente, 
passíveis das interpretações culturais que estes símbolos assumem dentro do espaço imaginário e social. De acordo com Mielietinski (1992), as concepções míticas não são estáticas, havendo em diferentes culturas, origens, um modo de significar o divino, dizendo-nos:

A mitologia grega é profundamente simbólica, a hindu é até certo ponto alegórica, a persa, esquemática; a grega é realista e evolui do infinito para o finito, enquanto a oriental, idealista, segue em sentido contrário. Para Scheling, o "caráter idealista" oriental (ênfase na essência, na ideia, no ideal) é rematada pelo cristianismo. Acha ele que a matéria da mitologia cristã não é natureza, mas a história, particularmente o maravilhoso na história enquanto esfera da Providência e dos valores morais; aqui o símbolo do universo das ideias não são a natureza e o ser, mas o homem e suas ações, ao invés da divinização do homem a humanização da divindade, tendo-se em vez do panteísmo a hierarquia (os anjos) e uma acentuada oposição entre o bem e o mal (anjo e o demônio). A religião poética é simultaneamente substituída pela religião da revelação. (MIELIETINSKI, 1992, p. 18,19. Grifo nosso.).

Os questionamentos em torno dessa religião da revelação, que interfere as concepções míticas de Deus e do Sagrado no Ocidente, interessam-nos particularmente no momento em que o elemento maravilhoso das histórias fantásticas, vistas nas narrativas míticas hebraicas e cristãs, perde a função alegórica e simbólica de caráter metafórico para tornar-se marcação de um tempo histórico-linear e, a partir de então, servir para fomentações de verdades intransponíveis representadas em divindade absolutas. Neste sentido, a supressão do elemento estético do texto, que deixa de ser fábula poética para tornar-se escritura sagrada, nada mais faz do que engessar os significados polissêmicos do símbolo no mito.

O oculto não atua mais, o maravilhoso já não existe, nenhum deus ou diabo pode agir a partir da formulação do pensamento técnico, tais imagens estão reduzidas aos paradigmas de ideias e interpretações historicizantes dos acontecimentos marcados por uma concepção de tempo linear e dogmas religiosos que, por sua vez, fundem-se nas objetividades do pensamento dualístico, distante e incompatível ao tempo mitológico. 
Desinibir-se dos tabus em torno das narrativas mítico-religiosas, que converteu o elemento simbólico em ideologia da consciência humana, nos conduz ao encontro do poético na narrativa mítica, o elemento poético que chama a presença o divino enquanto o sagrado ausente, mas desvelado na experiência estética da palavra.

Tal exercício, de chamar a presença aquele que antes esteve ausente através do poder do dizer mítico-poético, só pode atuar de acordo com as marcações de um tempo cujas conjugações semânticas sejam capazes de superar as dualidades do pensamento objetivante para adentrar a ambivalência do elemento simbólico, capaz de tornar o sagrado manifesto para além dos cerceamentos das ideias religiosas. A atuação de Deus no âmbito mítico-narrativo supera, portanto, a visão teosófica com base em absolutismos. Deste modo, é que:

\begin{abstract}
(...) o duplo demoníaco ou cômico do herói cultural - pícaro mitológico - também está especificamente correlacionado com o tempo mítico, tendo em vista que este tempo é anterior ao estabelecimento de toda sorte de tabus rigorosos. Até mesmo onde o senhor do céu atua como espírito principal, ele ou se funde com o demiurgo heróicultural, ou permanece uma figura bastante pálida e passiva, uma espécie de deus otiosus, que quase não desempenha qualquer papel nos temas narrativos. (MIELIETINSKI, 1992, p. 224)
\end{abstract}

As imagens do tempo potencializam as concepções de verdade e as formulações do pensamento, atrelando-se, consequentemente, à figura do divino e ao modo como os indivíduos pensam a si mesmo em relação a este Outro. O modo poético, como veremos, configura um sentido diverso, da religião, para ver e relacionar-se com deus, sendo este modo, não obstante, uma forma de interpelar sobre o próprio sentido de vida e morte que cada existência carrega em si.

\title{
O desvelamento da face demoníaca do divino na experiência poética em Poemas Malditos, Gozosos e Devotos, de Hilda Hilst
}


As obscuridades de Deus interessam, particularmente, a poeta Hilda Hilst, em Poemas Malditos, Gozosos e Devotos (1982), ao longo dos 21 poemas que compõem a obra, observamos um tipo de exercício de nomeação e busca do elemento divino. Herético e blasfematório, o eu poético hilstiano assume par si o exercício de pensar e nomear o Deus judaico-cristão, sendo esta uma forma de desvelamento da divindade e do si mesmo do eu lírico. Já na epigrafe introdutória dos textos poéticos, somos interprelados com a seguinte sentença de Simone Weil: "Pensar Deus é apenas uma certa maneira de pensar o mundo".

As múltiplas nomeações da divindade na poética hilstiana condizem, portanto, com a própria multiplicidade dos modos de serem dos indivíduos. Assim, o sádico Deus hilstiano contradiz toda normatividade do discurso dogmático-religioso ao agregar em si características que indicam um estado de humanidade e, portanto, de demonismo-divino, sendo ante a este personagem transversal aos diálogos estabelecidos nos textos poéticos que o eu lírico busca significar-se e construir uma ideia de si e desse Outrodivino (inefável), em forma de palavra-poética que permeia a experiência de um Sagrado dessacralizado. Segundo Marcel Conche (2006):

O sagrado é a categoria específica do religioso como tal, contudo, deixar a religião de lado não significa que não possa haver, no quadro da experiência humana ou do mundo humano algo que tenha uma espécie de afinidade ou de laço com o sagrado. Esse algo parece-me ser o demônico. Empresto essa categoria de Goethe: "o demônico", diz ele, "se manifesta das mais variadas maneiras em toda a natureza, seja ela visível ou invisível." (CONCHE, 2006, p.56).

No primeiro poema, já caracterizado por uma sequência de questionamentos que serão sempre direcionados a figura de um deus, expõe-se uma inversão moral do sentido em torno do sacrifício de Cristo. Vejamos o texto poético:

Pés burilados

Luz-alabastro

Mandou seu filho

Ser trespassado 
Nos pés de carne

Nas mãos de carne

No peito vivo. De carne.

Pés burilados

Fino formão

Dedo alongado agarrando homens.

Galáxias. Corpo de homem?

Não sei. Cuidado.

Vive do grito

De seus animais feridos

Vive do sangue

De poetas, de crianças

E do martírio de homens

Mulheres santas.

(...)

(HILST, 2005, p.13-15)

A plasticidade dos primeiros versos remete-nos, claramente, ao crucificamento do Cristo. A imagem do Cristo-homem transpassado em sua carne, como constantemente ressalta o eu lírico, traz a consciência humana o terror e o medo da informidade de um deus que não se sabe as atrocidades que vela suas intenções obscuras, já que mandou seu filho a crucificação e, não obstante, para consciência poética, ainda sendo um ser que se alimenta "(...) do grito/ De seus animais feridos/Vive de sangue/ De poetas, de crianças// E do martírio de homens/ Mulheres santas.".

Há nesses versos uma clara parodização da moral em torno do mito fundador do cristianismo, além de uma satirização do que seria o amor de um deus-criador por aquilo que não apenas é sua criação, mas seu próprio filho. A ironia da linguagem poética hilstiana, ao renarrar o mito sagrado da salvação no cristianismo, revela a monstruosidade de um Deus do qual somos advertidos a ter "cuidado". Neste poema, há um exercício de releitura e compreensão em torno da imagem do Cristo crucificado, que nos leva ao horror estético ao mesmo tempo em que se estabelece uma sedução, fixação, na carne, na vida, na matéria humana sacrificada, mortificada pelo divino. O caráter irônico desse poema traz a 
angústia de não se saber, ou ter definições, de uma divindade da qual se é servo, filho, criação. Ao fim desse mesmo poema, ante o terror causado por esse Outro-divino-desconhecido, o eu poético declara:

Cantando e dançando, digo:

Meu Deus, por tamanho esquecimento

Desta que sou, fiado da terra, um cisco

Beijo-te pé e artelhos.

(HILST, 2004, p. 15)

Não obstante, é a ausência de Deus que causa alívio, sendo o próprio lugar do desamparo aquele no qual o eu poético sente-se seguro. No poema subsequente, temos algumas características bizarras dessa divindade que, de acordo com a imaginação poética, tem as seguintes formas:

II

Rasteja e espreita

Levita e deleita.

É negro. Com luz de ouro.

É branco e escuro

Tem muito de foice

E furo.

Se tu és vidro

É punho. Estilhaça.

É murro.

Se tu és água.

É tocha. É máquina

Poderosa se tu és rocha.

Um olfato que aspira.

Teu rastro. Um construtor

De finitudes gastas.

É Deus.

Um sedutor nato.

(HILST, 2005, p.17) 
No poema acima, a figura do divino aproxima-se do que seria um lado obscuro do sagrado, no qual o elemento maravilhoso, comumente caracterizado pelo o que é elevado quando associado à imagem de um deus-criador, reveste-se de uma natureza animalesca, cuja perseguição ao homem acaba tornado, consequentemente, em uma divindade demoníaca. Nesses versos há mais do que uma humanização do divino, uma vez que o rebaixamento do sublime ao plano da natureza (carnal-erótico-animal), pertencente à presença de mundo humana, evoca a força do sagrado para além das fronteiras entre deuses e homens, das sublimações do corpo e dos espaços postas pelas mistificações de visões dogmáticas. A experiência do sagrado que extrapola a religião evoca uma dupla mística: a do sublime posto no plano da natureza, sendo esta vista como demoníaca por pertencer à dimensão carnal.

Portanto, a caracterização deste Deus, animalesco e cruel, que logo nos primeiros versos, sabemos que "Rasteja e Espreita/ Levita e Deleita", coloca o divino em confronto com os paradoxos da finitude humana, cuja fonte só pode estar na sua imagem obscura e aterradora para consciência humana. Assim, diz o eu poético: "Se tu és vidro/ É punho. Estilhaça. / É murro." (...) "É Deus um construtor de finitudes gastas". A divindade seria, assim, uma articuladora de ilusões, "É Deus é um sedutor nato", sendo a ilusão primeva posta na própria experiência humana, como diz o eu lírico, em outro poema, sendo preferível a "grande noite negra/ A esta luz irracional da Vida." (p.21). Em uma análise interpretativa sobre a constituição do elemento divino nas tessituras dos textos hilstianos, Anatol Rosenfeld nos diz que:

Os textos, no seu todo, com a audácia da sua linguagem em que o sagrado se reveste de atributos diabólicos e o monstruoso, de cores celestes, são uma celebração ritual levada ao desvario e ao paroxismo; ritual destinado a convocar a plenitude múltipla do homem em toda a sua imanência para, ao mesmo tempo, transcendê-la e fazer vislumbrar "os ares de lá".

Há, portanto, nos poemas hilstianos, um claro desejo de transcendência da finitude humana, que só é possível na rememoração de um tempo mítico capaz reunir deuses e homens, em seus paroxismos, no mesmo espaço, sendo este o espaço simbólico e metafórico da linguagem 
poética. O exercício da imaginação poética transgride as forças religiosas e os discursos harmônicos em torno da personalidade divina, colocandonos diante da monstruosidade de um Deus incomensurável, com o qual se luta confrontando a morte, a finitude, que está em uma consciência de Deus, sabendo-se, não obstante, que só a pulsação poética que torna este Outro existente, uma vez que Ele mesmo reúne em si os conflitos de uma natureza humana. Mais adiante, no poema III, o eu poético nos diz:

\author{
Sou façanha \\ Escuro pulsante \\ Fera doente. \\ À tua semelhança: \\ Homem. \\ (HILST, 2005, p.19)
}

Transportando o Absoluto ao mesmo fluxo de tempo e espaço da obscuridade vista na consciência humana, Hilst nos revela que a animalidade do homem esteve, primeiramente, em Deus, ou nas imagens que este imprime na consciência humana do divino.

\title{
Algumas considerações
}

As discussões realizadas até o presente momento podem até suscitar questões sobre o que a crítica moderna caracterizou como sendo marcas do antropomorfismo de Deus, todavia, o que observamos, com base em uma concepção de tempo anterior, a-histórico, vistas no tempo-espaço semântico dos mitos, é que os modos de representar e compreender os deuses e heróis-demiurgos modeladores culturais não abarcam as caracterizações demarcadas como pertencentes a esta ou aquela força oculta, uma vez que, as narrativas míticas são movidas pelo movimento paradoxal e o elemento divino caracteriza-se por uma imagem ambivalente de um duplo.

O fazer poético hilstiano resgata esse tempo mítico dessacralizado para alcançar um estado transcendente e, assim, harmonizar as dualidades fundadas em uma concepção de tempo linear, superando as sublimações e racionalizações impostas pelos dogmatismos e totalitarismos que institucionalizam a personagem de deus e a experiência do sagrado. 


\section{Referências Bibliográficas}

BLOOM, Harold. ROSENBER G, David. O livro de J. trad. Monique Balbuena. Rio de Janeiro: Imago ed., 1992.

CAMPBELL, Joseph. Mitologia na vida moderna: ensaios selecionados de Joseph Campbell. Trad. Luiz Paulo Guanabara. Rio de Janeiro: Record, 2002.

CONCHE, Marcel. O sagrado e a Solidão. In: O sentido da filosofia. São Paulo: Martins Fontes, 2006.

HILST, Hilda. Poemas Malditos, Gozosos e Devotos. São Paulo: Globo, 2005.

MIELIETINSKI, E. M. A poética do mito. Trad. Paulo Bezerra. Rio de Janeiro: Forense-Universitária, 1987. 


\title{
O Diabo na arte e no imaginário ocidental.
}

\author{
Antonio Carlos de Melo Magalhães ${ }^{1}$ \\ Eli Brandão ${ }^{2}$
}

\section{Introdução}

É possível identificar o desenvolvimento, as oscilações e as continuidades nas representações e crenças no diabo no âmbito da arte, da religião e das ideologias. Ainda que existam identidades epocais, que sedimentam a longa história humana, não podemos deixar de reconhecer matizes, especificidades na história do diabo no imaginário ocidental.

\section{Curta história do Diabo}

Indubitavelmente, a primeira grande sistematização e unificação foi elaborada pelos teólogos medievais dos séculos XII e XIII, resultado da ascensão do cristianismo à religião do Império, mas que encontrou sua grande sistematização justamente nos séculos mencionados, em seguida encontrou força especial nos séculos XIV a XVI nas mãos dos artistas renascentistas, saiu um tanto combalido da luta que enfrentou com o Iluminismo europeu nos séculos XVII e XVIII, foi redescoberto como mito literário de forma especial pelos autores românticos dos séculos

1 Doutor pela Universidade de Hamburg, Alemanha. Professor do Departamento de Filosofia e Docente Permanente do Programa de Pós-Graduação em Literatura e Interculturalidade da Universidade Estadual da Paraíba.

2 Doutor pela UMESP - São Paulo. Professor do Departamento de Letras e Docente Permanente do Programa de Pós-Graduação em Literatura e Interculturalidade da Universidade Estadual da Paraíba. 
XVII a XIX e não saiu incólume da indústria cultural do século XX, voltada para a transformação dos bens simbólicos em mercadorias sedutoras aos gostos do consumidor.

Claro, não estamos dizendo com esta visão panorâmica, baseada mais nas grandes representações de cada período, que o Diabo não existia antes nos imaginários e nas narrativas. As religiões monoteístas não deixam isto em dúvida. O Diabo faz parte dos imaginários religiosos, mas nossa hipótese de trabalho é que ele nunca foi assim tão importante como figura, pessoa, representação e força do imaginário como na Idade Média e depois no renascimento. Mesmo na Baixa Idade Média, por exemplo, Agostinho não recorre tanto à existência do diabo para explicar a queda, mas ao problema do mal. Quero dizer, ele não se apressa em personificar o mal, mas em compreendê-lo como parte do dilema da vida humana. Mesmo no Novo Testamento - com certeza responsável por boa parte das imagens que temos acerca do diabo -, ele é mais forte na literatura escatológica (alguns textos dos Evangelhos) e apocalíptica (Apocalipse de João), tendo somente relativa ou insignificante influência em outros livros.

No Primeiro Testamento/na Bíblia Hebraica sua participação é mais pedagógica que necessariamente um anti-Deus ou uma força em contraposição a Deus. Não há dúvida, porém, que o Diabo é quase sem importância para o conjunto de textos do Primeiro Testamento/da Bíblia Hebraica. E quando associações a esta imagem surgem, há uma dimensão de complementação ao divino, ao núcleo do sagrado.

O Diabo passou, portanto, por várias representações, tendo uma face terrível, mas muitas vezes apresentado com muita ironia, quase como um bufão da corte, e, outras vezes, como figura necessária à ordem do mundo. Então é sempre bom explicar de que Diabo estamos falando. De qualquer forma, ele é figura insuperável como mito religioso, como convicção religiosa mais conservadora, como parte do imaginário ocidental e constitutivo da arte no ocidente e no oriente.

Uma coisa é certa: o cristianismo é o principal responsável pela força do Diabo no mundo, pois é justamente nele que as representações e projeções do Diabo encontrarão um singular avanço na cultura e na civilização. 


\section{Arte, cultura popular e representações do Diabo}

Um longo caminho é percorrido para se chegar a grandes representações do Diabo na arte. O que a pesquisa especializada nos indica é que isto se deu especialmente a partir da força de algumas representações na cultura popular fortemente religiosa. Sim, porque nas primeiras grandes representações do teatro (grego e romano) o Diabo não tinha papel no palco nem nas letras. É dentro da cultura popular cristã e pagã que o Diabo passará a ter força na arte.

Numa grande circulação de bens simbólicos, o Diabo era uma entre tantas outras ofertas e a pesquisa deveria considerar este papel ainda subalterno para depois entender melhor o papel quase hegemônico que passou a ter.

Até o século XII o mundo era demasiado encantado para permitir a Lúcifer ocupar todo espaço do medo, do temor ou da angústia. O pobre diabo tinha concorrentes demais para reinar absoluto, ainda mais porque o teatro do século XII fazia dele uma imagem de paródia ou francamente cômica, retomando o veio popular referente ao Mal ludibriado. (MUCHEMBLED: 2001, p. 31)

E aí há vários aspectos a serem considerados, sumariamente apresentados por Russel.

A ligação mais íntima entre o Diabo da arte e o Diabo da literatura é o demônio do teatro. A elaborada literatura de visão do inferno influenciou as artes de representação tanto quanto Dante, e algumas pinturas são virtualmente ilustrações de tais visões. Arte e teatro influenciam-se pelo menos no fim do século XII, quando o teatro vernáculo começou a ser popular. A representação do Diabo no teatro foi derivada de impressões visuais e literárias, e em troca artistas que tinham visto produções de teatro modificaram a própria visão deles. $\mathrm{O}$ pequeno e preto diabinho que não pôde ser representado facilmente no teatro declinou no final da Idade Média. O desejo de impressionar as audiências com 
fantasias grotescas pode ter encorajado o desenvolvimento do grotesco na arte, fantasias de animais com chifres, rabos, presa, casco rachado e asas; fantasias de monstro, meio-animal e meio-humano; e fantasias com faces nas nádegas, barriga ou joelhos. Máscaras, luvas com garras e dispositivos para projetar fumaça pela face do demônio também eram usados. (RUSSEL: 2003, p. 245-6)

É justamente neste período de várias intersecções entre arte, cultura popular e religião, que a teologia e a instituição eclesiástica fortalecem a preocupação em sistematizar sua visão da ação do Diabo no mundo. Mais até: procuram mostrar a gravidade de um mundo dirigido pela força demoníaca.

Pode-se datar do fim do século XII, o momento em que, devido sobretudo à acentuação das ameaças heréticas, se passa de um estado de relativo equilíbrio na matéria a uma acentuada preocupação pela ação diabólica. A amplitude das ameaças com que se acha confrontada a Igreja, com os Bogomilos, os Valdenses e os Cátaros, sem esquecer a pressão turca e a presença dos judeus, explica em parte a atenção obsessiva que é dada ao Diabo. Como muito bem viu Jean Delumeau, instala-se na cristandade um medo difuso que ajuda a criar a idéia de que está em curso um ataque concentrado contra o cristianismo, um ataque conduzido por uma potência sobrenatural pelo inimigo, o Diabo. (MINOIS: 2003, p. 68)

Aqui não podemos deixar de perceber uma relação bastante ambígua da arte. Por um lado, ela captou bem as formas diversas da cultura popular lidar com as representações do Diabo, por outro, ela também serviu aos interesses sistematizadores da Igreja de tornar estas representações ainda mais fortes para o uso despótico da instituição numa verdadeira pedagogia do medo. Claro, até que ponto isto foi obra dos artistas ou mero uso institucional é algo que mereceria uma pesquisa à parte. De qualquer forma, é importante anotar esta ambigüidade presente na relação da arte com as representações do Diabo e seus usos institucionais. A mesma ambigüidade, talvez até de forma mais acentuada, encontramos no Renascimento. 
Outro capítulo importante é considerar o papel que o Iluminismo teve no processo de racionalização e desencantamento do mundo. Isto significou a emergência de grupos sociais cada vez mais preocupados em interpretar o mundo e seus fenômenos a partir de categorias racionais e não a partir de uma tutela do sobrenatural sobre o natural. É assim que vamos encontrar mudanças no discurso sobre o diabo e que ele entrará em declínio nos grandes sistemas teológicos e na arte sob a tutela da religião.

Entre o século XVI e o século XVIII, o discurso sobre o Diabo passa por uma mutação radical. Deixa de ser uma obsessão religiosa e, no período imediatamente anterior ao romantismo, transformase num grande mito literário. A substituição de Satanás por Mefistófeles não é fundamentalmente um processo de natureza religiosa, mas de natureza simbólica. Não se trata, portanto, de uma passagem da crença à descrença, mas uma transição entre mitos. O Diabo, com efeito, laiciza-se, o seu papel perpetua-se, mas com inversão de sinal. (MINOIS: 2003, p. 110)

A literatura romântica representou um momento forte da literatura em sua reescritura sobre o Diabo, propondo uma inversão na forma como o Diabo era interpretado. Por outro lado, não deixa de apresentar um diálogo com dimensões pedagógicas que a figura do Diabo tinha na Bíblia Hebraica. E fez isto ainda sob o impacto do Iluminismo.

O Romantismo transformará Satã no símbolo do espírito livre, da vida alegre, não contra uma lei moral, mas segundo uma lei natural, contrária à aversão por este mundo pregada pela Igreja. Satanás significa liberdade, progresso, ciência, vida. Tornar-se-á moda a identificação com o Demônio, assim como procurar refletir no semblante o olhar, o riso, a zombaria impressos nas feições tradicionais do Diabo. (...) O Diabo passa a representar a rebelião contra a fé e a moral tradicional, representando a revolta do homem, mas com a aceitação do sofrimento porque este é uma fonte purificadora 
do espírito, uma nobreza moral, da qual só pode surgir o bem da humanidade. E o demoníaco tornase o símbolo do Renascimento: demoníaco como paixão, como terror do desconhecido, como descoberta do lado irracional existente no homem: a explosão da imaginação contra obstáculos excessivos da consciência e das leis. (NOGUEIRA: 2000, p. 104-5)

Partimos do princípio que o uso que o romantismo faz do Diabo está dentro de uma tradição da arte já indicada neste texto, mas também representa um passo importante para a compreensão do Diabo como mito literário, criando um fosso entre a visão que se tem majoritariamente na religião e a visão que se tem na arte. Cada vez mais, após o romantismo, o Diabo perde espaço na literatura ou apropria-se de suas características para construir personagens complexos. O que era coisa do diabo passa a ser cada vez mais coisa do humano. Nas obras de escritores como Goethe (1749), Willian Blake (1757-1827), Balzac (1799-1850), Victor Hugo (1821-1867), além de Dostoiévski (1821-1881) entre outros, e Baudelaire (1821-1867) considerados ou românticos ou elos entre o romantismo e o modernismo, o imaginário literário significou um forte abalo do exclusivismo teológico. É o Diabo plenamente no mundo onírico, grotesco e fantástico, mas também com indicações importantes de que ele seria rapidamente relativizado dentro deste mundo.

Ao final do século XIX, o Diabo mostrava sinais evidentes de envelhecimento, primeiro porque sua existência fisica vinha sendo amplamente desacreditada, e depois porque sua função como metáfora do mal era considerada por muitos como ultrapassada. Assim, no início do século XX, novas e mais abstratas explicações filosóficas e políticas para os infortúnios mundanos já ocupavam um espaço muito mais amplo. Entretanto, mesmo relegado ao esquecimento, o Diabo continuou exercendo seu fascínio natural, pois embora os poetas, os artistas e os escritores o tivessem posto de lado em favor de outras soluções para os eternos dilemas da 
humanidade, a psique popular nunca deixou de tê-lo como bode expiatório, sobretudo nos tempos mais dificeis. (STANFORD: 2003, p. 279-80)

Com isto temos um processo crescente de interiorização do mal na literatura. Cada vez mais o que era atribuído ao Diabo, é um problema nosso ou da sociedade. O homem-humano, assim como indicado em textos de Guimarães Rosa, é a grande personificação do mal. A insatisfação e a ambigüidade da condição humana passam a ser cada vez mais motivos literários. É o natural que importa, não mais o sobrenatural.

\section{Literariedade e ambiguidades da figura do Diabo}

Partimos do pressuposto de que fenômeno da religião se manifesta na cultura de todas as civilizações conhecidas e que a literatura é, por excelência, escritora e reescritora dos discursos teológicos que forjam o imaginário ocidental, no qual, como temos argumentado, o Diabo aparece como uma figura central das tradições cristãs. Entretanto, pelo fato dessas referidas tradições serem construídas ao longo de um processo histórico no qual a ambiguidade humana é determinante e em meio a uma diversidade cultural, a figura do Diabo, consequentemente, mesmo dentro de um mesmo contexto [como se dissesse: "Meu nome é legião, porque somos muitos"] apresenta ambiguidades, numa riqueza polissêmica que transita entre o sério e o cômico, o espanto e a admiração, o belo e o grotesco, o oficial e o popular, o sacro e o profano, o bem e o mal, exemplarmente.

Ao entendermos a literatura como escritora e reescritora dos discursos da religião, queremos ressaltar o caráter literário das narrativas míticas em geral e, em particular, dos textos que formam a tradição judaico-cristã, afirmando que o mito somente se configura na superfície linguística como literatura, que a Bíblia, portanto, é Literatura. Neste sentido, e a partir da compreensão de que a literatura se constrói como intérprete das vivências pessoais e socioculturais do humano, como intérprete de textos verbais e não-verbais, orais e escritos, podemos dizer que a figura do Diabo apenas surge na escrita por meio da expressão literária. Assim, a literatura continua a criar e recriar, refletir e refratar os diversos percursos temáticos e figurativos do Diabo, evidenciando o seu caráter 
palimpsêstico e pluridiscursivo, possibilitando que se estabeleça em seu interior um produtivo diálogo entre diversos discursos, onde vozes teológicas falam e polemizam com outras e entre si.

Ao selecionarmos a dimensão literária para refletirmos sobre a figura do Diabo, não pretendemos reduzir a abordagem à moda dos formalistas russos, mas buscamos seguir a concepção de texto, no sentido de Greimas \& Courtès, como unidade da manifestação, o lugar onde um plano de conteúdo é manifestado por meio de um plano de expressão. A unidade do plano de conteúdo é o discurso, patamar do percurso gerativo de sentido em que as estruturas narrativas são assumidas por um enunciador, actorializadas, especializadas, temporalizadas e revestidas de temas e/ou figuras (apud FIORIN, 1994, p. 30-31). Neste sentido, o texto não pode ser considerado como algo em si, pois, por um lado, ele é um sistema concluído, um conjunto hierarquizado de configurações estruturais internas; por outro, é o lugar onde se manifestam e se expressam relações entre textos e textos, entre textos e pessoas, entre textos e realidades socioculturais, ou seja, texto aqui entendido como um objeto aberto, plural, dialógico, ligado ao contexto extraverbal.

A partir disso, entendemos que as figuras do Diabo presentes nos diversos textos literários estão em permanente diálogo interdiscursivo com outros textos, em relação aos quais definem suas identidades e/ou diferenças (MAINGUENEAU, 1997), num processo de reconfiguração incessante, incorporando elementos pré-construídos e/ou provocando sua redefinição.

A literatura, como já vimos, por meio de sua criação e representação, tem mostrado, ao longo da história, uma riqueza em exemplos de figuras do Diabo e, mais abundantemente, de figuras do Diabo horripilante e maléfico, em oposição ao Deus do bem, este relacionado à virtude pelo discurso teológico oficial das igrejas cristãs, mas também figuras de um Diabo mais bondoso, cômico e integrado à divindade.

Selecionamos aqui, exemplos de figura do Diabo na literatura através do qual podemos vislumbrar no interdiscurso semelhanças e diferenças, bem como sutilidades teológicas que trazem à tona contradições internas ao discurso da igreja cristã, expressivas também das ambiguidades e interpretações dos fiéis em sua vivência cristã. 
Proust (1994, p.103), em A propósito de Baudelaire, já ressaltava como o poeta dAs Flores do Mal, no poema "As Litanias de Satã", refletia e ao mesmo tempo refratava conceitos da tradição teológica cristã, ao sugerir que beleza, majestade, esperança, o Deus, a quem se dirige a oração do aflito e "o cuidado de ensinar a mais profunda teologia está confiado a Satã”.

Ó tu, o Anjo mais belo e o mais sábio Senhor,

Deus que a sorte traiu e privou de louvor, Tem piedade, Satã, desta longa miséria! (...)

Tu, sábio e grande rei do abismo mais profundo, Médico familiar dos males deste mundo, Tem piedade, Satã, desta longa miséria!

(...)

Ó tu, o que da Morte, a tua velha amante, Engendraste a Esperança - a louca fascinante!

Tem piedade, Satã, desta longa miséria!

E prossegue o poeta Baudelaire, apontando relações sutis de polêmica com os discursos da teologia da igreja cristã, mas, ao mesmo tempo, em sintonia com possível hermenêutica do texto do Livro de Gênesis.

\section{ORAÇÃO}

Glória e louvor a ti, Satã, nas amplidões

Do céu, em que reinaste, e nas escuridões

Do inferno, em que vencido, sonhas com prudência! Deixa que eu, junto a ti, sob a Árvore da Ciência, Repouse, na hora em que, sobre a fronte, hás de ver Seus ramos como um Templo novo se estender!

Reflitamos agora em torno de uma obra na qual o Diabo é refigurado, neste caso, como personagens divinas multifacetárias, num interdiscurso que refletem e refratam figuras da tradição cristã. Selecionamos para este fim uma prosa da literatura brasileira, o Romance d'A Pedra do Reino e o príncipe do sangue do vai-e-volta, de Ariano Suassuna.

O Romance da Pedra do Reino é a auto-descrição do híbrido reino de Quaderna, uma bricolagem carnavalizante do mundo ibérico, através 
de sua literatura medieval e da tradição teológica da igreja cristã de vertente católica, tecida no contexto da cultura nordestina, numa ressignificação literária do movimento histórico-fantástico conhecido como "Pedra Bonita" ou "Pedra do Reino".

Quaderna, personagem principal e narrador, que, inspirado pela leitura do folheto da literatura de cordel, intitulado "O Estudante que se vendeu ao Diabo", de Lino Pedra-Verde, passa a andar com um espelho, depois do que teve uma visão, semelhante a que teve o estudante de Salamanca com o Diabo no cordel de Lino, através da qual ele viu refletido no espelho um vulto de uma Onça formada de pedras, mato estradas, sol... a qual foi the envolvendo e tragando para dentro de um buraco perigoso, oco e vazio. Depois dessa experiência, são recorrentes as aparições de entidades malignas multiformes que se opõem ao seu reino.

Em alguns momentos, por meio de uma refração interdiscursiva, esses personagens diabólicos e ameaçadores são identificados com forças políticas internacionais e intercontinentais, de direita e de esquerda, os quais são identificados por Quaderna, na forma indeterminada de "eles".

Eles era uma entidade maléfica que nunca consegui identificar precisamente, mas que, segundo parecia, era e é ligada à Besta Anglo-Saxã, à Besta-LouraCalibã - uma entidade que está em toda parte, inatingível, ameaçadora, invencível e diabólica. (SUASSUNA, p. 260).

Às vezes, o diabo é descrito dentro de um ambiente bem regional na forma animalesca de "cachorro", numa cena que ocorre no Chafariz perto do rio Taperoá, num depósito de lixo (SUASSUNA, 2006, p.328330). Em outra passagem, aparece também o diabo numa forma feminina: "uma diaba-fêmea do Mar e do Litoral, uma bicha horrorosa", também chamada de Bruzacã ou Hipupriapa ou Ipupiara. Ela tem aparência de peixe, mas peitos e cabeça de cachorro e orelhas num formato parecido com chifre. Para Quaderna, o mal da seca e da opressão é causado pela interferência desse Diabo, que "é o Mal, o Enigma, a Desordem!" (SUASSUNA, 2006, p.402). Trata-se de um demônio marinho e sertanejo, que passa seis meses no mar causando tempestades e devorando as Baleias. O mesmo Diabo, em setembro, sai do Mar, soprando fogo 
pelas ventas, causando a seca no sertão (SUASSUNA, 2006, p.403). Dependendo do período do ano e com a modalidade de aparição, marítima ou terrestre, esse Diabo feminino toma formas diferentes:

Ah, só quem já viu Bruzacã é que pode imaginar como são poderosas e aterrorizantes as formas que ela toma! São sete Chifres turvos e amolados, o Focinho peludo, a Corcova cerúlea! No cabelouro espesso, uma Cabeleira de serpentes e conchas entrançadas! O olhar de Cobra e o corpo feito à semelhança de um corpo enorme de Touro branco! Era a Besta marinha, partejada pelos lombos diabólicos e sagrados do Mar! Seu olhar chamejava, ora amarelo, ora azul como um aço de Martelo! Ao fogo do sopro das suas Ventas, ferviam as águas em borbulhas de Enxofre envenenado. O peito era coberto pelo musgo nojento que suja e mancha as paredes do Inferno alumiado! As espáduas eram cobertas de malhas feridentas cor de ferrugem e em cada uma das suas ancas verdes luzia uma estrela amarela, brilhando entre sargaços e salsugem, entre ostras pegadas ao tronco, anoso e velho como um velho Rochedo extraviado! (SUASSUNA, 2006, p.406)

Singular figuração do Diabo podemos observar no Reino de Quaderna, no que se refere à "Santíssima Trindade Sertaneja", que se apresenta com membros zoomórficos da fauna nordestina, num evidente interdiscurso tecido em diálogo polêmico e carnavalizante com a composição da santíssima trindade da teologia cristã católica.

O próprio Deus não era mais aquele sopro tênue das outras religiões: aparecia-me como a Santíssima Trindade Sertaneja, um Sol ardente e glorioso, formado por cinco animais num só. Era a Onça Malhada do Divino, integrada por cinco bichos: a Onça-Vermelha, a Onça-Negra, a Onça-Parda, a Corça Branca e o Gavião de Ouro, ou seja, o Pai, o Encourado, o Filho, a Compadecida e o Espírito Santo. (SUASSUNA, 2006, p.561). 
Para além da definição da composição da Santíssima Trindade Sertaneja, com cinco membros e com a inclusão do Diabo e da Compadecida, a oração invocatória não deixa dúvidas sobre a relação simbólica entre os animais e as pessoas da trindade:
Ó Onça-Vermelha do Pai! Ó Onça Negra do Encourado! Ó Onça Parda e Castanha do Filho! Ó Corça Branca! Ó Gavião de Ouro do Sol do Espírito Santo! (SUASSUNA, 2006, P. 558).

A Santíssima Trindade Sertaneja de Quaderna está profundamente relacionada a sua primeira experiência com o Diabo, por ocasião da visão que teve, e ao cenário do Nordeste brasileiro, de modo que é a Onça quem representa o conjunto da divindade:

Santíssima Trindade tem cinco, e é sempre figurada através do animal heráldico e armorial brasileiro por excelência, a Onça Malhada (SUASSUNA, 2006, p.551).

Pode parecer muito excêntrica a configuração da Santíssima Trindade Sertaneja de Quaderna, mas ela, interdiscursivamente, refrata mais a teologia oficial da igreja católica e menos a teologia do catolicismo popular, destacadamente aquele muito mais sincrético e livre do 'povão'. Isto porque, desde a Idade Média, quando o Diabo ganhou mais crédito, até os nossos dias, no contexto eclesiástico e fora dele, o Diabo sempre se apresentou como muito poderoso, com um poder divino que pode pôr à prova alguém que esteja sendo acusado de ser ou não ser cristão. Neste contexto, observamos que nos sermões dos padres e pastores há abundância de argumentação no intento de provar que o Diabo existe e que é poderoso. A prova de alguém ser ou não ser cristão não é, nesse caso, crer em Cristo, mas sim crer no Diabo, acreditar que ele existe e que é poderoso.

Por muito tempo ouvimos e ainda podemos ouvir hoje em corredores de discussão nas igrejas ou nos seminários de teologia, nas casas e nas ruas, a tese de que: quem não acredita na existência do Diabo não pode ser crente ou cristão. O Diabo é causa necessária do Deus cristão, Deus tem necessidade ontológica do Diabo, nessa compreensão. Assim, a configuração interdiscursiva da Trindade Sertaneja é não apenas criadora, 
mas também recriadora de determinados sentidos presentes na realidade da comunidade cristã. $O$ mesmo se pode dizer em relação à inclusão da Compadecida como membro da trindade sertaneja, visto que ela também se apresenta como divindade no catolicismo popular, em muitos contextos, com autoridade acima do Pai, do Filho e do espírito Santo.

Do que vimos, a figura do Diabo é histórica e teológica, polêmica e harmoniosa, sacra e profana, do bem e do mal, sendo sua semântica reconstruída por meio de um processo hermenêutico permanente a partir das vivências humanas, das expressões das artes em geral e dos textos verbais, de forma especial, da arte da palavra, a literatura, e do lugar discursivo do enunciador em seus diferentes contextos socioculturais, onde esse ser mitológico, essa figura do discurso e essa representação do vivido é de novo apropriada, refigurada, tecida, engendrando ressignificação dos sentidos possíveis para a existência humana. 


\section{Referências Bibliográficas}

BAUDELAIRE, Charles. As Flores do Mal. Trad., introd. e notas de Jamil Mansur Haddad. São Paulo: Difel, 1995.

FIORIN, José Luiz. Elementos de Análise do Discurso. São Paulo: Ed. Contexto, 1994.

MAINGUENEAU, Dominique. Novas tendências em análise do discurso. São Paulo/Campinas: Pontes/Editora UNICAMP, 1997.

MINOIS, G. O Diabo: origem e evolução histórica. Lisboa: Terramar, 2003

MUCHEMBLED, Robert. Uma história do diabo - séculos XII-XX. Tradução de Maria Helena Kühner. Rio de Janeiro: Bom Texto, 2001.

NOGUEIRA, C. R. F. O diabo no imaginário cristão. Bauru: Edusc, 2000.

Bruxaria e história: as práticas mágicas no ocidente cristão.

Bauru: Edusc, 2004.

PROUST, Marcel. A propósito de Baudelaire. in: Nas trilhas da crítica. Trad. Plínio Augusto Coelho. São Paulo: Edusp, 1994.

RUSSEL, Jeffrey Burton. O Lúcifer e o Diabo na Idade Média. São Paulo: Editora Madras, 2003.

STANFORD, P. O Diabo: uma biografia. Rio de Janeiro: Gryphus, 2003.

SUASSUnA, Ariano. Romance d'A Pedra do Reino e o príncipe do sangue do vai-e-volta. 8.ed. Rio de Janeiro: José Olympio, 2006. 




\section{LIVROS EDUEPB E LATUS}

1. Pluralismo Jurídico: Para além da visão monista - Raíssa de Lima e Melo

2. Mulher, corpo e cuidado - Maria de F. de A. Silveira; e Dulce M. Rosa Gualda

3. Avaliação de serviços: um olhar na qualidade da gestão - (Orgs) Maria José Cariri Benígna; e Maria A. Amado Rivera

4. Farmacêutico na Farmácia - Rosimary S. Cunha Lima; Maria do Carmo Eutálio; e Magnólia de L. S. Targino

5. Representações sociais e saúde - Aliana Fenandes; Maria. do R de Carvalho; e Moisés Domingos Sobrinho

6. EPI Info para iniciantes - (Orgs) Sonia Maria de L. Maciel; e Pedro Henrique de A. e S. Leite

7. Ensino de lingua: do impresso ao virtual - (Orgs) Antonio de Pádua Dias da Silva; Maria de L. L. Almeida; Simone Dália de Gusmão Aranha; e Tereza. N. de Farias Campina

8. A história da mídia regional - C. B de Souza; F. G. de Oliveira; e Gorete M. Sampaio de Freitas

9. Livro de resumo de monografias - Maria Dora Ruiz Temoche

10. Planejamento tributário no campo de incidência do ICMS - Alexandre H. S. Ferreira; e Ana Maria da P. Duarte

11. 1930 - A Revolução que mudou a História do Brasil - (Orgs) João M. L. Santos; Cláudo José L. Rodrigues; Inês Caminha L. Rodrigues; e José Octávio de A. Melo

12. Curso de Direito Constitucional - Lorivaldo da Conceição

13. Fragmentos - Juarez Filgueras de Góis

14. Gênero em questão - (Org) Antonio de Pádua Dias da Silva

15. Jogos eletrônicos - Eliane de M. Silva; Filomena M. G. da S. C Moita; e Robson Pequeno de Souza

16. Nascido do Fogo, Filho da Paz - Ket Jeffson Vasconcelos Leitão

17. Política Tributária e Justiça Social - Alexandre Henrique Salema Ferreira

18. Revista Sócio-Poética - Departamento de Letras da UEPB

19. O Sábio e a Floresta - Moacir Werneck de Castro

20. Universidade e o fazer poético em prosa e poesia - (Orgs) Fabíola Nóbrega; Marcelle V. Carvalho; e Tatiana Fernandes Sant'ana

21. Sustentabilidade - um enfoque sistêmico - (Orgs) Waleska S. Lira; Helio de L. Lira; Maria José dos Santos; e Lincon Eloy de Araújo

22. Bioquímica clínica - uma abordagem geral - Sandra Reis Farias

23. Mortalidade Geral - Epidemologia - Anthonyanny A. Silva Lima; Maria J. Cariri Benigna

24. Estudos Filológicos: Literatura - Cultura - Marinalva Freire da Silva

25. Dicionário de termos relativos a gestão de pessoas - Maria Dora Ruiz Temoche

26. Práticas de Políticas Públicas - (Orgs) Marcelo A. Pereira; Maria da G. A. Pereira; Sandra. M. A de S. Celestino; Sueli Ramos de R. M. Cavalcanti; e Wíliam A. de Lacerda

27. Saúde Humana - (Org) Inácia Sátiro Xavier de França

28. O Segredo de Pergamo - Ket Jeffson Vasconcelos Leitão

29. A queda do meteorito - Giusone Ferreira Rodrigues

30. Trajetória empreendedora: estudo de casos numa realidade local e global - (Org) Vera Lúcia Barreto Motta

31. Identidades de gênero e práticas discursivas - (Org) Antonio de Pádua Dias da Silva

32. O lugar da Educação Física - Maria José de Fígueirêdo Gomes

33. O papel político dos fóruns de educação de jovens e adultos - Eduardo Jorge Lopes da Silva

34. Pesquisa histórica - resumo de monografias - (Orgs) Luíra Freire Monteiro; e Flávio Carreiro de Santana

35. Anos de luta - Waldir Porfírio

36. Mulher e violência: histórias do corpo negado - Lígia Pereira dos Santos 
37. Agricultura orgânica - José Geraldo R. dos Santos; e Emmanuelly Calina X. R. Santos

38. Sobre o diálogo: introdução a uma leitura filosófica de - Julio Cesar Kestering

39. Novos cenários da Administração - (Org) maria Dora Ruiz Temoche

40. O despertar da cultura - (Org) Marinalva Freire da Silva

41. Manual básico de Radiologia Odontológica - Maria de Fátima Cavalcanti Rodrigues

42. Formas de sociabilidade e instauração da alteridade - Inácia S. Xavier de França; Lorita M. Freitag Paghuca

43. Paremiologia nordestina - Fontes Ibiapina

44. Resistência indígena no Piauí colonial 1718 - 1774 - João Renor F. de Carvalho

45. Planejando o (des)envolvimento local - Roberto Alves de Araújo; e Ana Siqueira de Araújo

46. Deuses em poéticas: estudos de Literatura e Teologia - (Orgs) Salma Farraz; Antonio Magalhães; Eli Brandão; Waldecy Tenório; Douglas Conceição

47. Campina Grande em debate - (Org) Roberto Véras de Oliveira

48. História do Direito e da violência: recortes de uma abordagem interdisciplinar - Marcelo Alves Pereira Eufrásio

49. Contos jurídicos: normas de sobredireito da Lei de Introdução ao Código Civil - Ket Jeffson Vasconcelos Leitão

50. A Bacia do Rio Gramame: Biodiversidade, uso e conservação - (Orgs) José Etam de Lucena Barbosa; e Takako Watanabe; e R. José da Paz

51. Ser criança - repensando o lugar da criança na educação infantil - (Orgs) Glória M. de Souza Melo; Soraya. M. de A. Brandão; e Marinalva. da Silva Mota

52. Estudos Sociais da Ciência e Tecnologia - (Org) Renato Dagnino

53. De portas abertas para o lazer - (Orgs) Elaine Melo de B. Costa Lemos; Eduardo Ribeiro Dantas; e Cheng Hzin Nery Chão

54. Gênero e práticas culturais - (Orgss) Charliton J. dos Santos Machado; Idalina M. F. Lima Santiago; e Maria L. da Silva Nunes

55. Da resistência ao poder - o (P)MDB na Paraíba (1965 / 1999) - José Otávio de Arruda Mello

56. Políticas públicas e desenvolvimento regional - (Orgs) Carlos. A. Máximo Pimenta; Cecília Pescatore Alves

57. Histórias vividas e contadas no Bar do Brito - (Orgs) A. C. Barbosa de Souza; Antonio Guedes Rangel Junior; Clara M. Araújo Pinto; e Sonia Maria A. de Oliveira Brito

58. De memória e de identidade - (Orgs) Antonia M. M. da Slva; Francisco Paulo da Silva; Ivanaldo Oliveira dos Santos; e Maria Edileuza da Costa

59. A luz que não se apaga - Rômulo de Araújo Lima

60. Cálculo avançado - (Orgs) Aldo Trajano Louredo; e Alexandro M. de Oliveira; e Osmundo Alves Lima

61. Fisioterapia na gravidez - (Org) Maria do Socorro B. e Silva

62. Educação Universitária - Pedro Bergamo

63. Amora - Fidélia Cassandra

64. Educação em questão - recortando temas e tecendo ideias - (Pedro Lúcio Barboza)

65. Ciço de Luzia - Efigênio Moura

66. Zila Mamede - trajetórias literárias e educativas - Charliton José dos Santos Machado

67. A voz da infância e outras vozes - Calos Azevedo

68. A Educação da Mulher em Lima Barreto - (Jomar Ricardo da Silva)

69. Porta aberta à poesia popular - Almira Araújo Cruz Soares

70. Mulheres representadas na literatura de autoria feminina - Antonio de Pádua Dias da Silva

71. Residências terapêuticas - (Orgs) Maria de Fátima de A. Silveira e Hudson Píres de O. Santos Júnior

72. A nuvem de hoje - Braulio Taveres

73. Tecnologias digitais na educação - (Orgs) Robson Pequeno de Sousa; Filomena M. C. da S. C. Moita; e Ana Beatriz Gomes Carvalho. 
74. A representação da sogra na obra de Leandro Gomes de Barros - José Itamar Sales da Silva

75. Viagem aos 80 anos da Revolta de Princesa - Janduí Dantas

76. Cidadania glocal, identidade nordestina - José Marques de Melo

77. Uma nova ciência para um novo senso comum - Marcelo Germano Gomes

78. A feira - o trovador encantado - Maria de Lourdes Nunes Ramalho

79. Nordeste como inventiva simbólica - Geralda Medeiros Nóbrega

80. Era uma vez diferente - Aline Pereira

81. Colecionismo, práticas de campo e representações - Maria Margaret Lopes e Alda Heizer.

82. Ensaios de Antropologia da Política - Elizabeth Christina de Andrade Lima

83. A Bela Acordada - Lígia Pereira dos Santos

84. Eu macharei na tua luta - a vida de ELISABETH TEIXEIRA - (Orgs) Lourdes M. Bandeira; Neide Miele; Rosa M. G. Silveira

85. Apropriação Social da Ciência e da Tecnologia - (Orgs) Maria C. P. I. Hayashi; Cidoval M. de Sousa; e Danilo Rotrberg

86. Midiatização da Ciência - cenários, desafios, possibilidades - (Org) Antonio Fausto Neto

87. Psicologia da Saúde - teoria, intervenção e pesquisa - (Org) Railda Fernandes Alves

88. As periércias de um caçador de ETs - Jorge Dellane da Silva Brito

89. Becquerel e a descoberta da radioatividade - Roberto de Andrade Martins

90. Mpb de A a Z (2 ediçâo) - Ricardo Anísio

91. ECO - Juarez Filgueras de Góis

92. As três verdades de Deus - Janduí Dantas

93. Sabedoria de cabôco - José Alves Sobrinho

94. Agenda Ambiental - gestão socioambiental - (Org) Antônio Augusto Pereira de Sousa; Djane de Fátima Oliveira; Givanildo Gonçalves de Farias; e Mercília Tavares Jordão

95. Etnografia e Educação - conceitos e usos - Carmen Lúcia Guimarães de Mattos; e Paula Almeida de Castro

96. Orgulho de ser caririzeiro - Victor Paulo Sampaio

97. Genealogia do Direito à Saúde - Marcone do Ó Catão

98. Antonio Carlos Nóbrega em acordes e textos armoriais - Luís Adriano Mendes Costa

99. Identidades \& sensibilidade - o cinema como espaço de leituras - (Org) Iranilson Buriti

100. Dom José Maria Pires - Uma voz fiel à mudança social - (Org) Sampaio Geraldo Lopes Ribeiro

101. Paisagens Híbridas - Fontes e escrituras da História - (Org) Juciene Ricarte Apolinário

102. Cenários históricos e educativos - Sertão, questão indígena e espaço de saber - (Org) Juciene Ricarte Apolinário 
Sobre o livro

Impressão Gráfica Universitária da UEPB

Formato $16 \times 23 \mathrm{~cm}$

Mancha Gráfica $\quad 11,5$ x $18,5 \mathrm{~cm}$

Tipologias utilizadas Bembo Std 11,5/14

Papel Apergaminhado $75 \mathrm{~g} / \mathrm{m}^{2}$ (miolo) e Cartão Supremo $250 \mathrm{~g} / \mathrm{m}^{2}$ (capa) 